\title{
Guides to some Volcanic Terranes in Washington, Idaho, Oregon, and Northern California
}

David A. Johnston and Julie Donnelly-Nolan, Editors

GEOLOGICAL SURVEY CIRCULAR 838 


\section{UNITED STATES DEPARTMENT OF THE INTERIOR \\ JAMES G. WATT, Secretary}

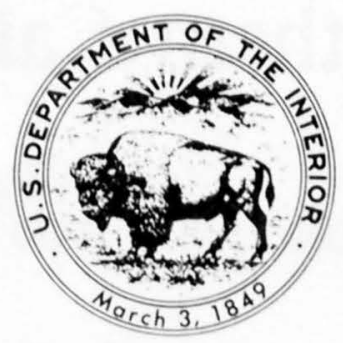

Geological Survey

H. William Menard, Director 


\section{CONTENTS}

Guide to geologic field trip between Lewiston, Idaho, and Kimberly, Oregon, emphasizing the Columbia River Basalt Group by D. A. Swanson, U.S. Geological Survey, Menlo Park, California 94025; and T. L. Wright, U.S. Geological Survey, Reston, Virginia 22092 type, Columbia River Basalt Group -

3. Maps showing distribution, feeder dikes of four formations in Columbia River Basalt Group -

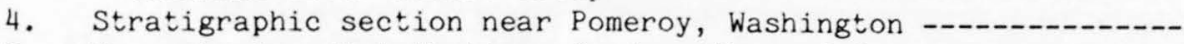

5. Maps showing distribution, feeder dikes of four members in two formations of Columbia River Basalt Group -

6. Idealized cross section of flow in Yakima Basalt Subgroup -.--

Table 1. Major-element compositions of chemical types, Columbia River Basalt Group -.-

2. Trace-element compositions of chemical types, Yakima Basalt Subgroup -

Roadlog for geologic field trip between Lewiston, Idaho, and Kimberly, Oregon by D. A. Swanson, U.S. Geological Survey, Menlo Park, CA 94025; and T. L. Wright, U.S. Geological Survey, Reston, VA 22092

Figure 1. Map of field trip stops

Guide to geologic field trip between Kimberly and Bend, Oregon with emphasis on the John Day Formation by Paul T. Robinson, Department of Earth Sciences, University of California, Riverside, CA 92521; and Gerald F. Brem, Department of Earth Sciences, California State University, Fullerton, CA 92634

Figure 1. Index map of north-central Oregon with extent of John Day Formation - -

2. Stratigraphic columns, western and eastern John Day Formation-

3. Chemical analysis, least altered John Day ash-flow tuffs ----

Roadlog for geologic field trip between Kimberly and Bend, Oregon, with emphasis on the John Day Formation by Paul T. Robinson, Department of Earth Sciences, University of California, Riverside, CA $92521-\ldots$

Figure 3. Map of field trip stops

Central High Cascade roadside geology, by Edward M. Taylor, Department of Geology, Oregon State University 
Roadlog for Central High Cascade geology, Bend, Sisters, McKenzie Pass, and Santiam Pass, Oregon by Edward M. Taylor, Department of Geology, Oregon State University-n

Figure 3. Geologic sketch map, mile 0.0 to 16.6

4. Geologic sketch map, mile 16.6 to 27.1

5. Geologic sketch map, mile 27.1 to 34.5 to 44.6

6. Geologic sketch map, mile 44.6 to 57.9

7. Geologic sketch map, mile 57.9 to 72.3

8. Geologic sketch map, mile 72.3 to 83.5

9. Geologic sketch map, mile 83.5 to 91.6 to 99.8

10. Geologic sketch map, mile 99.8 to 119.0

11. Geologic sketch map, mile 119.0 to 129.1

12. Geologic sketch map, mile 129.1 to 142.0

60

63

65

69

71

74

76

78

80

82

Newberry Volcano, Oregon by Norman S. MacLeod, David R. Sherrod, U. S.

Geological Survey, Menlo Park, CA 94025; Lawrence A. Chitwood, U.S. Forest Service, Bend, OR 97701; and Edwin H. McKee, U. S. Geological Survey, Menlo Park, CA 94025

Figure 1. Geologic sketch map of Newberry Volcano

2. Geologic sketch map of Newberry caldera

Table 1. Representative chemical analyses of Newberry rocks ---

Roadlog for Newberry Volcano, Oregon, by Norman S. MacLeod, David R. Sherrod, U. S. Geological Survey, Menlo Park, CA 94025; Lawrence A. Chitwood, U.S. Forest Service, Bend, OR 97701; and Edwin H. McKee, U. S. Geological Survey, Menlo Park, CA 94025

High Lava Plains, Brothers fault zone to Harney Basin, Oregon by George W. Walker, U. S. Geological Survey, Menlo Park, CA 94025, and Bruce Nolf, Central Oregon Community College, Bend, Oregon

Figure 1. Index map showing High Lava Plains and Harney Basin -.....--

2A, B, C. Route map with major structural elements and rhyolite $\mathrm{K} / \mathrm{Ar}$ ages -

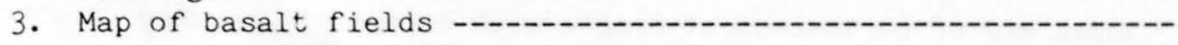

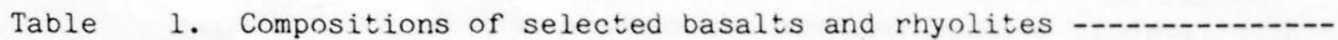

Roadlog for High Lava Plains, Brothers fault zone to Harney Basin, Oregon, by George W. Walker, U. S. Geological Survey, Menlo Park, CA 94025, and Bruce Nolf, Central Oregon Community College, Bend, Oregon

A field trip to the maar volcanoes of the Fort Rock-Christmas Lake Valley basin, Oregon, by G. H. Heiken, Geosciences Division, Los Alamos Scientific Laboratory, Los Alamos, NM 87545; R. V. Fisher, Department of Geology, University of California, Santa Barbara, CA 93106; and N. V. Peterson, State of Oregon, Department of Geology and Mineral Industries, Grants Pass, OR 97526

Figure 1. Location map -

2. Map of Fort Rock-Christmas Lake Valley Basin, showing route of field trip 
Figure 3. Cross sections through Moffitt Butte, Klamath County, Oregon -

4. Photograph of maar deposits, Big Hole

5. Map of Hole-in-the-Ground -

6. Geologic section through Hole-in-the-Ground -

7. Fort Rock tuff ring: map, photograph, cross section ---.----

8a. Map of Table Rock tuff ring complex

8b. Stratigraphic section of sediments under Table Rock tuff ring complex -

9. Diagram of sediment-tuff-breccia contact, Table Rock tuff ring complex --

10. Sketch of cliff showing vent 8 , Table Rock tuff ring complex -

11. Diagram showing palagonitization of tuff, Table Rock maar complex -

12. Map and cross sections of vents 4 and 5, Table Rock tuff ring complex --

13. Sketch and map of vent 5, Table Rock tuff ring complex --.---

14. Stratigraphic section, Table Rock tuff cone -..-..--

15. Cross section, Table Rock

16. Sketch and map of vent 9, Table Rock tuff ring complex ------

17. Slump structure in tuff ring 1, Table Rock, and sketches showing its formation

Table 1. Chemical analyses of basalts, Fort Rock-Christmas Lake Valley Basin

Roadlog for field trip to Medicine Lake Highland by Julie M. Donnelly-Nolan, U.S. Geological Survey, MS-18, 345 Middlefield Road, Menlo Park, CA 94025; Eugene V. Ciancanelli, Cascadia Exploration Corporation, 3358 Apostal Road, Escondido, CA 92025; John C. Eichelberger, Geological Research G-6, Los Alamos Scientific Laboratory, Los Alamos, NM 87545; Jon H. Fink, Geology Department, Stanford University, Stanford, CA 94305; and Grant Heiken, Geological Research G-6, Los Alamos Scientific Laboratory, Los Alamos, NM 87545

Figure 1. Location map for field trip to Medicine Lake Highland -----

Captain Jack's Stronghold (The geologic events that created a natural fortress) by Aaron C. Waters, 308 Moore Street, Santa Cruz, CA 95060. Map by David Kimbrough and Aaron C. Waters

Figure 1. Map of Captain Jack's Stronghold

Pre-Holocene silicic volcanism on the northern and western margins of the Medicine Lake Highland, California by Stanley A. Mertzman, Department of Geology, Franklin and Marshall College, Lancaster, PA 17604

Figure 1. Geologic map of selected units, Medicine Lake Highland -

Table 1. Analytical results of $\mathrm{K}-\mathrm{Ar}$ dating

2. Chemical analyses of the Andesite Tuff 
Figure 3. Chemical analyses of the lava flow equivalent of the Andesite Tuff and of older silicic rocks

4. Modal analyses of the Andesite Tuff -

5. Chemical analyses of three Holocene glass flows -......-..-

Surface structure of Little Glass Mountain by John H. Fink, Geology Department, Stanford University, Stanford CA 94305 (Present address: Department of Geology, Arizona State University, Tempe, AZ 85281) -.---

Figure 1. Schematic cross section through a rhyolitic obsidian flow ----

2. Flow front, Little Glass Mountain: photo, foliations, interpretation ----

3. Map of part of northeast lobe, Little Glass Mountain --------

4. Compressional folds in flow front, Little Glass Mountain -----

5. Diagram of diapir rise in rhyolitic obsidian flow --.--.----

6. Map of part of northwest lobe, Little Glass Mountain -.---.--

7. Map of large ridge, northwest lobe

8. Photo, part of northwest lobe, Little Glass Mountain --------

Holocene plinian tephra deposits of the Medicine Lake Highland, California, by Grant Heiken, Los Alamos Scientific Laboratory, Geosciences Division, Los Alamos, NM 87545

Figure 1. Map of deposits $<1100$ years old, Medicine Lake Highland -----

2. Isopach map of Little Glass Mountain and Glass Mountain

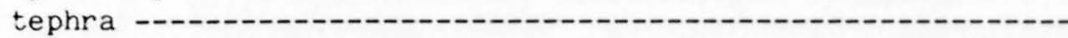

3. Correlation of Little Glass Mountain tephra units ---------

Table 1. Age relations of Holocene volcanic deposits, Medicine Lake Highland

Mechanism of magma mixing at Glass Mountain, Medicine Lake Highland volcano, California, by John C. Eichelberger, Geosciences Division, University of California, Los Alamos Scientific Laboratory, Los Alamos, NM 87545

Figure 1. Map of Glass Mountain sample locations and lithologic units --

2. Map showing distribution of Holocene lavas, Medicine Lake Highland -

3. Cross section through Medicine Lake Highland volcano --------

4. Photomicrographs of basaltic xenolith in Glass Mountain rhyodacite, shown in reflected light, transmitted light, and crossed polars -

5. Graph of density versus pressure, Glass Mountain materials ---

6. Sketches of probable eruptive sequence at Glass Mountain -----

Table 1. Densities of Glass Mountain samples 


\section{PREFACE}

This guidebook arose out of a series of field trips held in conjunction with the pacific Northwest American Geophysical Union meeting held in Bend, Oregon, September 1979. The PNAGU meeting included special volcanology sessions planned by William I. Rose, Jr., Bruce A. Nolf, and David A. Johnston. Publication of the guidebook volume was originally planned for early 1980 by the Oregon Department of Geology and Mineral Industries (DOGAMI). Inevitable delays, subsequent scheduling problems, and the death of Dave Johnston in the May 18 eruption of Mount St. Helens led to this publication as a USGS Circular.

This circular differs from typical U.S. Geological Survey compilations in that not all these papers have been examined by the Geologic Names Committee of the Survey. This Committee is charged with ensuring consistent usage of formational and other stratigraphic names in U.S. Geological Survey publications. Because many of the contributions are from workers outside the Survey, review by the Geologic Names Committee would have been inappropriate. Each author provided camera-ready pages, and the articles have not been edited for uniformity of style or usage.

The contributions are generally ordered so as to describe the areas from north to south. Typically, the roadlog comes after the descriptive article except in the case of the Medicine Lake Highland articles, for which the road $l o g$ is first and several topical contributions follow.

I wish to thank Wes Hildreth for responding so quickly to my request for a memorial to Dave Johnston. Also, my thanks go to Beverly Vogt of DOGAMI for her help with publication.

Most of all, we owe special posthumous thanks to Dave Johnston for conceiving the field-trip ideas, overseeing the planning and arrangements for the trips and maintaining his sense of humor in spite of the last-minute airline strike, and reminding us gently but firmly to produce the promised articles.

Julie Donnelly-Nolan 


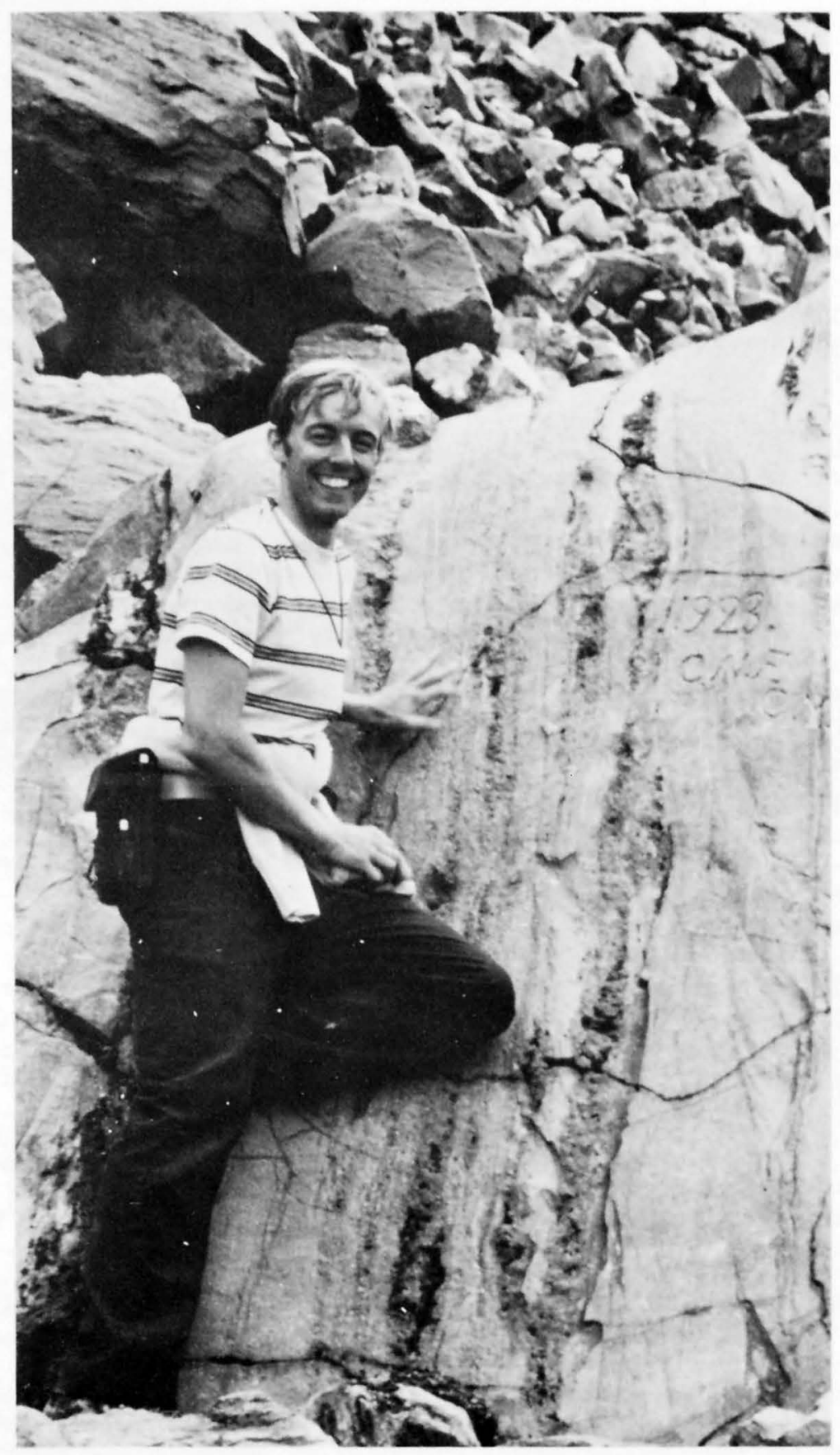

Dave Johnston, relaxed and happy in the land he loved, Valley of Ten Thousand Smokes, Alaska, June 1978. Posing here at the base of Novarupta, the rhyolite dome extruded at the close of the great eruption of 1912, Dave had sampled the fumaroles atop several nearby volcanoes and had undertaken a study of the emplacement, compaction, and welding of the 1912 ash-flow sheet. The initials are those of petrologist C. N. Fenner and his assistant Charles Yori, who worked in the valley in 1919 and 1923. (Photo by Dan Kosco.) 
Dave Johnston, 30-year-old volcanologist with the U.S. Geological Survey, was swept away by the great directed blast of Mount St. Helens on May 18, 1980. Because Dave had been an organizer of the AGU meeting at Bend, an editor of its abstracts and field-trip guidebooks, and a champion of the Pacific Northwest, it is particularly appropriate to dedicate this volume to him, in grateful remembrance of the effect that Dave's enthusiasm, diligence, and vitality had upon so many of us. As a working colleague and daily running companion, I was asked to try to summarize Dave's career and my impressions of him.

Dave Johnston was born and raised in Illinois, and it remained his custom to return there every Christmas season to visit his parents and sister, who survive him. At school and college, Dave became an outstanding scholar, runner, and photographer and, in 1971, he graduated from the University of Illinois with "Highest Honors and Distinction" in Geology. His first geologic project was on the Upper Peninsula of Michigan where, ten years ago, he studied the progressive metamorphism of a pile of Precambrian basaltic lavas and a differentiated gabbroic sill. Here was the inception of Dave's petrographic acuity and, here too, in an associated intrusion of gabbro and diorite, were the roots of Dave's first volcano.

In 1971 and 1972, Dave assisted Pete Lipman in mapping the Platoro and Lake City calderas in the San Juan Mountains volcanic field of southwestern Colorado. This fortunate apprenticeship so confirmed his enthusiasm for field petrology that, as a graduate student at the University of Washington, Dave undertook a detailed mapping, dating, and geochemical study of the Cimarron Volcano, an andesitic complex of oligocene age in the western San Juans. His intricate reconstruction of the eruptive style and structural history of this center from evidence provided by its intertonguing pyroclastic and alluvial deposits prepared Dave very well for his big jump to the study of active volcanism.

The jump came in the summer of 1975 when, with Jürgen Kienle's group from Fairbanks, Dave took part in a geophysical survey of Augustine Volcano, an island in lower Cook Inlet. When Augustine erupted explosively in early 1976, Dave rushed back to study the sequence and mechanisms of its eruptions and the petrology of their ejecta. His careful field and microprobe work demonstrated convincingly (1) that the pyroclastic flows had become less pumiceous with time (correlating with a change in emplacement mechanism); (2) that $\mathrm{H}_{2} \mathrm{O}, \mathrm{Cl}$, and $\mathrm{S}$ contents of the magmas were notably high; and (3) that basaltic magma, although at no time actually erupted, had mixed with the more silicic melts and had possibly triggered their outburst. Only 25 months later, Dave turned in his Ph.D. thesis, not on his nearly completed Cimarron project, but on Augustine. This was a remarkable achievement, since both studies were labor-intensive and of high quality.

Every summer Dave returned to Augustine and, in 1978 and 1979 , he went to Katmai as well. In the Valley of Ten Thousand Smokes, Dave was taking the lead in studying physical aspects of the emplacement, compaction, welding, and degassing of the ash-flow sheet as part of our comprehensive restudy of the 1912 eruption. The fundamental role of the gas phase in volcanic processes had, by 1978, led Dave increasingly to focus his work upon magmatic volatile components, the main evidence for which is preserved in glass-vapor inclusions within phenocrysts, in quenched crystal-liquid equilibria, and in the fumarolic emissions of active volcanoes. Characteristically, Dave pursued all three lines of evidence vigorously. He became an exceptionally rigorous analyst, whether with the microprobe, gas chromatograph, extraction line, or mass spectrometer, but Dave knew better than most not to waste his time on a lousy sample. Thus, he put enormous energy into improving the equipment and techniques necessary to collect meaningful and representative samples, especially the least fractionated and least contaminated gas samples possible. Dave's agility, nerve, patience, and determination around the jet-like summit fumaroles in the crater of Mt. Mageik were to me a spectacle of unforgettable beauty.

His work on volcanic gases brought Dave in 1978 to the U.S. Geological Survey, where he was assigned to expand our program for monitoring volcanic emissions in Alaska and in the Cascades. He knew that such studies could improve our understanding of the nature and evolution of magma bodies, eruptive mechanisms, and contributions of magmatic volatiles to hydrothermal systems, but I think Dave's dearest hope was 
that systematic monitoring of fumarolic emissions might permit detection of changes characteristically precursory to eruptions. Behind the image conveyed by his exceedingly solitary work was, in fact, a great concern for making a contribution to society. Dave wanted to formulate a general model for the behavior of magmatic volatiles prior to explosive outbursts and to develop a corollary rationale for the evaluation of hazards. But Dave also held the conviction that, as a scientist, he should devote time, energy, and imagination sufficient to communicate effectively to the non-scientific public the true range of potential volcanic hazards, the geologic (or sometimes instrumental) reasons for our poor predictive capability, and some notion of the characteristic time scales upon which volcanic behavior proceeds. Dave's concern for the societal importance of his work was nowhere more evident than in the thoroughness and dedication with which he recently undertook an assessment of the geothermal-energy resources of the Azores and mainland Portugal. Also during his last year, Dave developed growing interests in volcanic contributions of halogens, sulfur, and $\mathrm{CO}_{2}$ to the atmosphere and in the long-range effects on climate, health, and agriculture of both volcanic and anthropogenic emissions.

Thus, it was only in part by accident that when Mount St. Helens resumed its activity in March 1980, Dave Johnston was the first geologist on the mountain. From the earliest outbreak until the catastrophic event, Dave spent virtually the entire seven weeks at Mount St. Helens, monitoring $\mathrm{SO}_{2}$ emissions with a correlation spectrometer and coordinating the airborne sampling of gases and particulates. It deserves emphasis that Dave's work was an important contribution to a well-coordinated, scientifically multi-faceted, group effort that persuaded the authorities to resist public pressures to re-open the area around the volcano, thereby holding the May 18 th death toll to a few dozen instead of thousands. Ironically, Dave was caught at an observation post thought to be relatively safe, by an unusual eruptive event that was largely unanticipated, in magnitude or style, except perhaps by Dave himself. Three years ago, Dave had published this warning about Augustine: "High-temperature and high-velocity shock waves extended far beyond the limits of discernable deposits [of the 1976 eruption]. Hazard zones defined on the basis of deposits [alone do not] reflect this more extensive shock-wave hazard, which at Augustine extends many kilometers offshore." No one was more aware of the danger of directed blasts, pyroclastic surges, and the shock waves that sometimes accompany explosive eruptions than was Dave Johnston. Dave repeatedly voiced his convictions that studies of deposits left by old eruptions provide only part of the story and that informed hazards assessment requires accepting the dangers of on-site monitoring of active volcanic processes. Dave was unaffectedly genuine in everything he ever said or did, so he gave his energy and vitality to advance our understanding and thus our predictive capability.

Dave Johnston is gone now, and many of us who were close to him can still scarcely believe it. Dave was a natural scientist in the finest sense, and to the extent that natural science is a collaborative effort, he was our shining example, and we are all diminished. His infectious curiosity and enthusiasm, his unaffected concern for the opinions and feelings of other people, and his joyful spontaneity uplifted his friends and touched people who barely knew him. His generosity was unsurpassed, and I am recurrently astonished whenever I recall that Dave voluntarily carried $40 \mathrm{~kg}$ of rocks out of Katmai for me. Dave Johnston was as self-aware and capable a person as $I$ have ever known, a man who would learn to do and dared to do whatever might be necessary to get the job done. In his final year, he began taking a night course to improve his mathematics. And, fed up with the stage fright that plagued his speaking career (though he gave excellent talks), Dave took the bull by the horns and (though he otherwise rarely drank) solved the problem by taking a jug to the podium with him.

But perhaps his most essential quality was the ability to dissipate cynicism spontaneously and to uplift the mood all around him. Dave looked for, saw, and thereby encouraged the best in all of us. Dave Johnston would expect us to carry on the game without him, with all his wonderful enthusiasm.

Wes Hildreth

July 1980 
GUIDE TO GEOLOGIC FIELD TRIP BETWEEN LEWISTON, IDAHO AND KIMBERLY, OREGON,
EMPHASIZING THE COLUMBIA RIVER BASALT GROUP

\section{D.A. Swanson, U.S. Geological Survey, Menlo Park, California 94025}

and

T.L. Wright, U.S. Geological Survey, Reston, Virginia 22092

The Columbia River Basalt Group comprises a tholeitic flood-basalt province of moderate size (fig. 1), covering an area of about $2 \times 10^{5} \mathrm{~km}^{2}$ with an estimated volume of about $2 \times 10^{5} \mathrm{~km}^{3}$ (Waters, 1962). The group is the youngest assemblage of flood basalt known, with an age range from about 17 to 6 m.y. ago; most eruptions took place between about 17 and $14 \mathrm{~m} . \mathrm{y}$. ago (Watkins and Baksi, 1974; McKee and others, 1977). It is the only flood basalt province of Phanerozoic age in North America.

Wide-ranging regional studies of the basalt, underway for the last 10 years, have been devoted primarily to defining stratigraphic and chemical relations for use in unraveling the history of the province and comparing the Columbia River Basalt Group with flood basalt elsewhere. Recently, these studies have been accelerated because of the need to know more about the stratigraphy and structure of the basalt as related to potential storage of nuclear waste within the basalt pile. A geologic map of the entire province is under preparation. Reconnaissance geologic maps of the basalt in most of Washington and northern Idaho have been completed (Swanson and others, 1979a) and eventually will be published in color (for example, Swanson and others, 1980). Studies in 1978 and 1979 were conducted by full-time and temporary personnel of the U.S. Geological Survey under Interagency Agreement No. EW-78-I-06-1978 with the U.S. Department of Energy in support of the Basalt Waste Isolation Program, administered by Rockwell Hanford Operations, Richland, Washington. Personnel involved in this mapping project have been: J.L. Anderson, R.D. Bentley, G.R. Byerly, V.E. Camp, J.N. Gardner, P.R. Hooper, D.A. Swanson, W.H. Taubeneck and T.L. Wright.

\section{GENERAL ASPECTS}

The Columbia River Basalt Group is characterized by most features considered typical of flood-basalt provinces. Flows are voluminous, typically $10-30 \mathrm{~km}^{3}$ with a maximum volume of $700 \mathrm{~km}^{3}$, and many cover large areas, as much as $40,000 \mathrm{~km}^{2}$. They generally advanced as sheetfloods, rather than as channelized or tube-fed flows, and form thick cooling units composed of one or more flows. Eruptions took place from fissure systems tens of kilometers long. Eruption rates were high, generally greater by $2-3$ orders of magnitude than those of other Cenozoic basalt provinces, as determined by 1) theoretical considerations based on the relations among eruption volumes, dimensions of linear vent systems, and distance traveled without appreciable crystallization or cooling breaks, and 2) the absence of constructional shields even though viscosities calculated at constant temperature from dry-weight chemical analyses are equal to or higher than those for oceanic tho- leites containing similar amounts of Mgo. Small spatter ramparts formed along fissures but are poorly preserved owing to bulldozing and rafting by flows and to later erosion. Cinder cones are very rare. In these and other features, basalt of the Columbia River Basalt Group contrasts with that produced by basaltic plains or oceanic volcanism (Greeley, 1977), as in the Snake River Plain, Iceland, and Hawaii.

The flows cover a diverse assemblage of rocks ranging in age from Precambrian to Miocene. The prebasalt topography had considerable local relief, 1000 $\mathrm{m}$ or more in places, near the margin of the columbia Plateau. Some of the prebasalt hills today stand high above the plateau surface, especially in the Spokane area. Little is known about the nature of the rocks or pre-basalt surface beneath the central part of the plateau. Sparse evidence from a drill hole $3.24 \mathrm{~km}$-deep just west of the Pasco Basin suggests that a thick weathered or altered zone caps a sequence of lower Tertiary volcanic rocks of mafic and intermediate composition at least $1970 \mathrm{~m}$ thick (Raymond and Tillson, 1968; Newman, 1970; Jackson, 1975; Swanson and others, 1979b).

\section{STRATI GRAPHY}

Formal stratigraphic subdivision of the Columbia River Basalt Group has recently been made (Swanson and others, 1979b) (fig. 2). Considerable effort was expended in doing this, in order to provide a strong framework for topical studies. Some additional distinctive units have been found in Idaho and Oregon since the nomenclature for the Columbia River Basalt Group was established, but they can easily be given member rank and assigned to one of the three formations in the Yakima Basalt Subgroup.

The criteria used to recognize specific stratigraphic units include megascopic and less commonly microscopic petrography, magnetic polarity, and chemical composition. Megascopic petrography and magnetic polarity can be determined in the field and, taken together in over-all stratigraphic context, are generally sufficient to identify a particular unit. Ambiguities commonly arise, however, and chemical analyses provide an invaluable and independent guide for checking and correcting field identifications. In fact, use of chemical analyses for correlation purposes is so rewarding that no study of the basalt requiring identification of flows should be undertaken without provision for chemistry. Physical characteristics such as weathering color, size and shape of vesicles, thickness, and type of columnar jointing have been used by some past workers as correlation criteria, but we have found them unreliable because of lateral variability except in some local areas. 


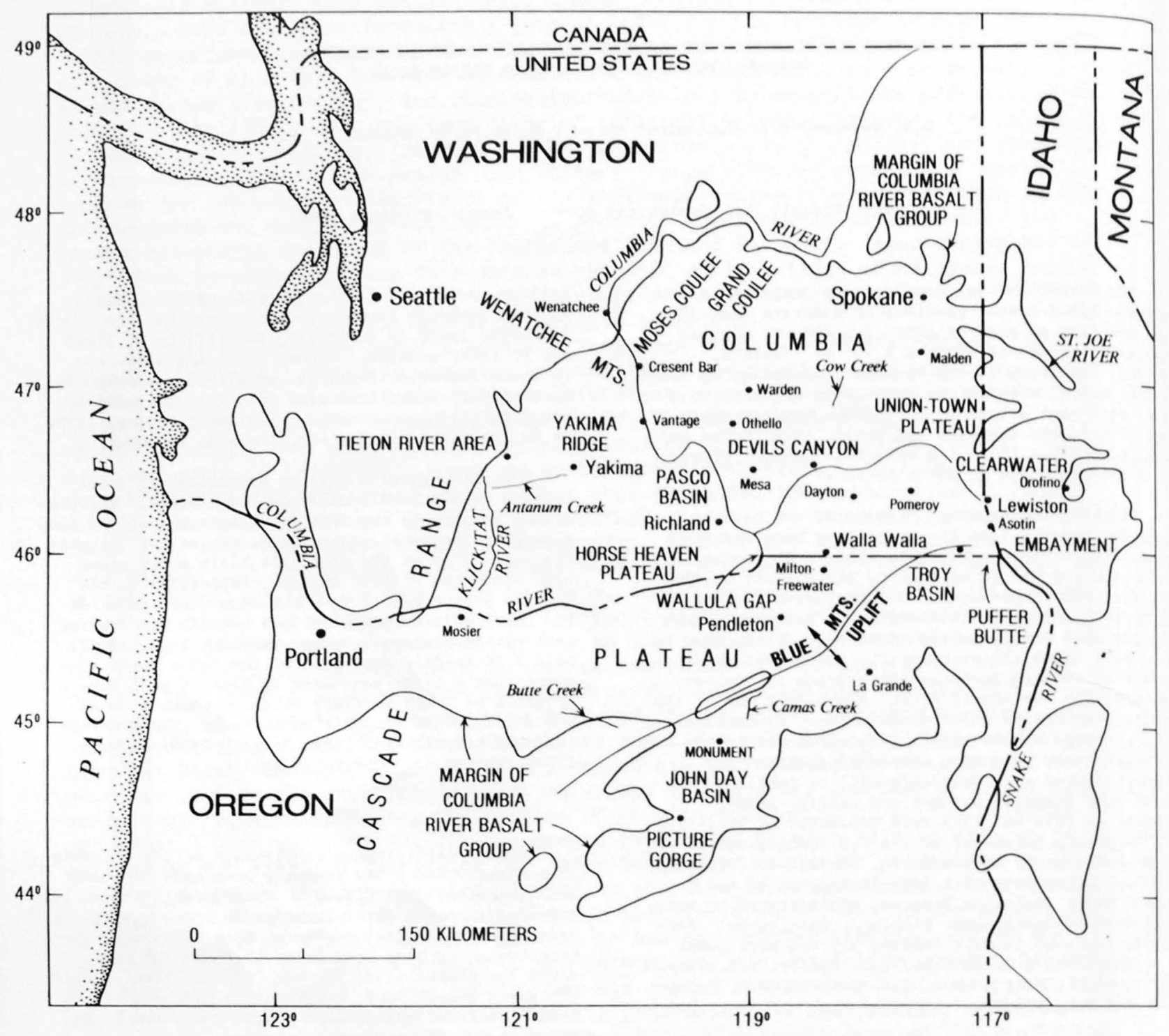

Figure 1. Index map showing approximate outcrop extent of the Columbia River Basalt Group (from waters, 1961) and locations mentioned in text. See figure 7 for details in southeast Washington and northeast Oregon.

The formal stratigraphic units of the Columbia River Basalt Group (fig. 2) have been described in detail by Mackin (1961), Bingham and Grolier (1966), Schmincke (1967b), Swanson and others (1979b), Swanson and Wright (1978), and Camp and others (1979); only general statements are made here.

\section{Imnaha Basalt}

Outcrops of the Imnaha Basalt, the oldest formation in the group, are confined to extreme southeast washington, nor theast Oregon, and adjacent parts of Idaho, where feeder dikes are known (fig. 3A).

Whether the Imnaha occurs farther west beneath younger rocks is conjectural. It covers a surface of rugged local relief and has an aggregate thickness of more than $500 \mathrm{~m}$. Most flows in the formation are coarse grained and plagioclase phyric (Hooper, 1974). Five chemical types have been distinguished (Holden and Hooper, 1976; Kleck, 1976; Vallier and Hooper, 1976; Reidel, 1978; table 1). Trace element compositions are given by Nathan and Fruchter (1974). Many flows contain zeolite amygdules (Kleck, 1976), and smectitic alteration is widespread. The Imnaha Basalt conformably underlies the Grande Ronde Basalt, and future work may find areas in which the two form- ations interfinger. Most of the Imnaha has normal magnetic polarity, but the oldest and youngest flows known have reversed polarity, based on measurements with a portable fluxgate magnetometer. Two samples of the Imnaha have ${ }^{87} \mathrm{Sr} /{ }^{86} \mathrm{Sr}$ initial ratios of .7044 and .7043 (McDougall, 1976). 


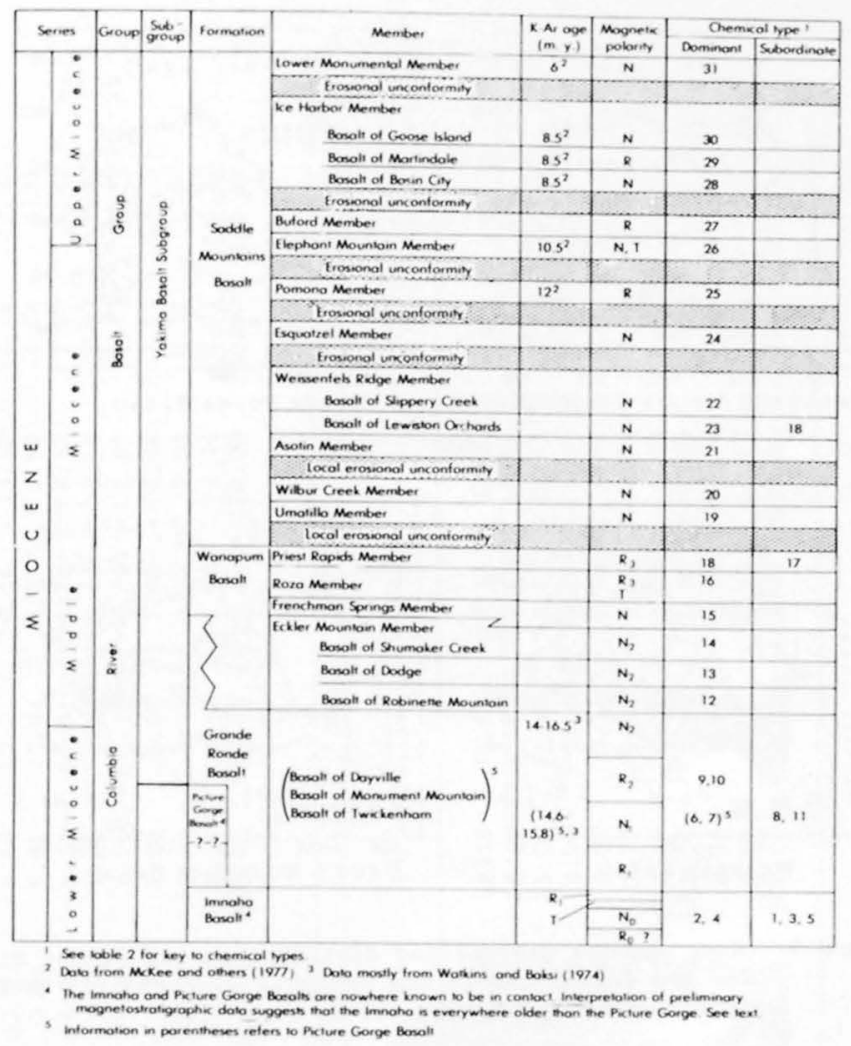

Pigure 2. Stratigraphic nomenclature, age, magnetic polarity, and chemical type for units in the Columbia River Basalt Group. $\mathrm{N}$, normal magnetic polarity; R, reversed; T, transitional. Subscripts refer to magnetostratigraphic units of Swanson and others $(1977 ; 1979 \mathrm{~b})$. Geologic time scale from Berggren and Van Couvering (1974). From Swanson and others (1979b).

\section{$\underline{\text { Picture Gorge Basalt }}$}

Much of the Picture Gorge Basalt is apparently coeval with the middle part of the Grande Ronde Basalt (fig. 2), as judged by the interfingering of the two formations (Cockerham and Bentley, 1973; Nathan and Fruchter, 1974) and reconnaissance magnetostratigraphic work (R.D. Bentley and D.A. Swanson, unpub. data, 1977) along lower Butte Creek, Oregon (fig. 1). The Picture Gorge crops out only in and surrounding the John Day Basin in north-central Oregon (fig. 3A), where feeder dikes comprise the Monument dike swarm (Waters, 1961; Fruchter and Baldwin, 1975). Possibly the ancestral Blue Mountains uplift kept most flows from spreading northward out of the basin. The formation is at least $800 \mathrm{~m}$ thick; Thayer and Brown (1966) report a thickness of more than $1800 \mathrm{~m}$ at one locality, although faulting may have duplicated part of the section. The picture Gorge contains aphyric to highly plagioclase-phyric flows with compositions falling into a broad field known as picture Gorge chemical type (Wright and others, 1973; table 1). Trace element data are given by Osawa and Goles (1970) and Nathan and Fruchter (1974). Some of the thicker flows contain pegmatoids (Lindsley and others, 1971). The formation can be subdivided into three informal units based on field characteristics and magnetic polarity, according to R.D. Bentley (Swanson and others, 1979b). The Picture Gorge at its type section has an average ${ }^{87} \mathrm{Sr} /$ ${ }^{86} \mathrm{Sr}$ initial ratio of .7037 (McDougall, 1976).

\section{Grande Ronde Basalt}

The Grande Ronde Basalt is the oldest formation of the Yakima Basalt Subgroup (fig. 2) and the most voluminous and areally extensive formation in the entire Columbia River Basalt Group, underlying most of the Columbia Plateau (fig. 3B) with an estimated volume of more than $150,000 \mathrm{~km}^{3}$. Its thickness varies widely depending on underlying topography; the thickest preserved section exceeds $1000 \mathrm{~m}$ in drill holes in the Pasco Basin, and sections $500-700 \mathrm{~m}$ thick $\propto$ ccur in the Blue Mountains and other uplifted or deeply incised areas. Most flows in the formation are very sparsely plagioclase-phyric to essentially aphyric, although a few of the oldest flows in and near the Lewiston Basin contain abundant large plagioclase phenocrysts. Major element compositions fall in a broad range termed Grande Ronde chemical type (table 1). Flows having different compositions within this range are interleaved throughout the section, although flows of high-Mg type rather consistently overlie flows of low-Mg type in the western part of the plateau. The Grande Ronde Basalt is subdivided into four magnetostratigraphic units on the basis of magnetic polarity (Swanson and wright, 1976b; Swanson and others, 1979b); these units provide the only useful subdivisions of the formation on a plateau-wide basis. Peeder dikes occur throughout the eastern half of the plateau and are apparently not confined to distinct swarms as formerly thought (Waters, 1961). The Grande Ronde conformably over- 


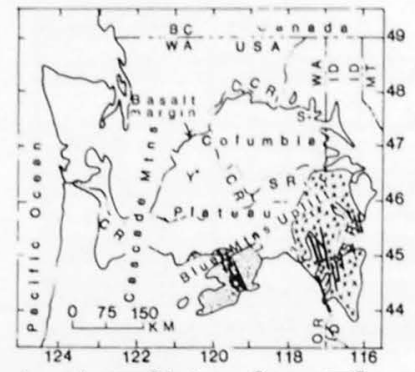

Imnaham Picture Gorge $\square$ Basalt

A

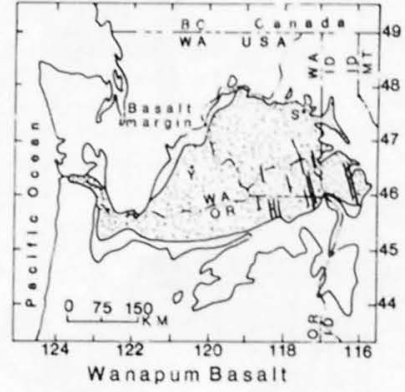

C

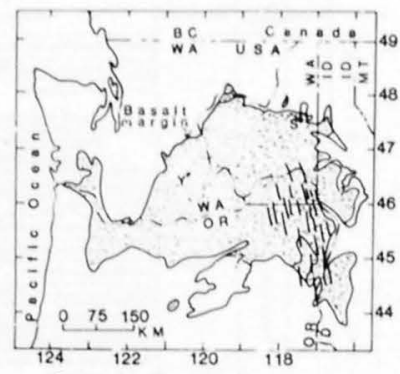

Grande Ronde Basalt

B

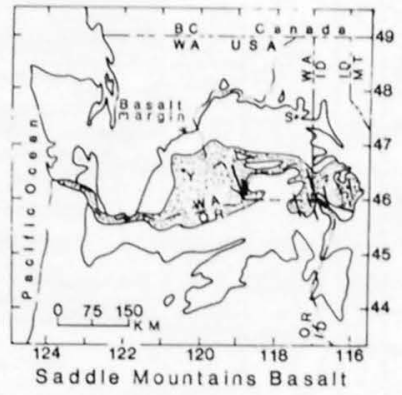

D

Figure 3. Maps showing generalized distribution and feeder dikes for the formations in the Columbia River Basalt Group. From Swanson and Wright (1978, fig. 3.4).

lies the Imnaha Basalt, intertongues with the picture Gorge Basalt, and conformably underlies and locally interfingers with the Wanapum Basalt. Commonly a thick soil and, locally, weakly lithified clastic sediments occur on top of the Grande Ronde; they indicate a significant time break, although probably no longer than a few tens of thousands of years judging from the local interbedded relations between the Grande Ronde and Wanapum Basalts in southeast Washington (fig. 4). The ${ }^{87} \mathrm{Sr} /{ }^{86} \mathrm{SR}$ initial ratios may increase slightly upsection, from values of about .7046 in the older flows to about .7052 in the younger flows (McDougall, 1976); this interpretation is tentative, as the older flows were sampled at different locations than the younger flows, so that variation due to lateral isotopic heterogeneity in the source rocks is also possible.

\section{Wanapum Basalt}

The Wanapum Basalt is the most extensive formation exposed at the surface of the Columbia Plateau (fig. 3C) but is much less voluminous than the Grande Ronde, probably having a volume of less than 10,000 $\mathrm{km}^{3}$. On a local scale, the Wanapum conformably overlies the Grande Ronde, except for minor erosional unconformities or interbedded relations. On a regional scale, however, the wanapum overlies progressively older basalt from the center toward the eastern margin of the plateau. Such onlap is not apparent along the northern and western margins, however. These relations suggest that the plateau had tilted westward before Wanapum time.

The oldest member of the Wanapum Basalt, the Eckler Mountain Member, occurs in the Blue Mountains and adjoining foothills of southeast washington and northeast Oregon (Swanson and others, 1979b, 1980). The oldest flow in the member, the basalt of Robin-

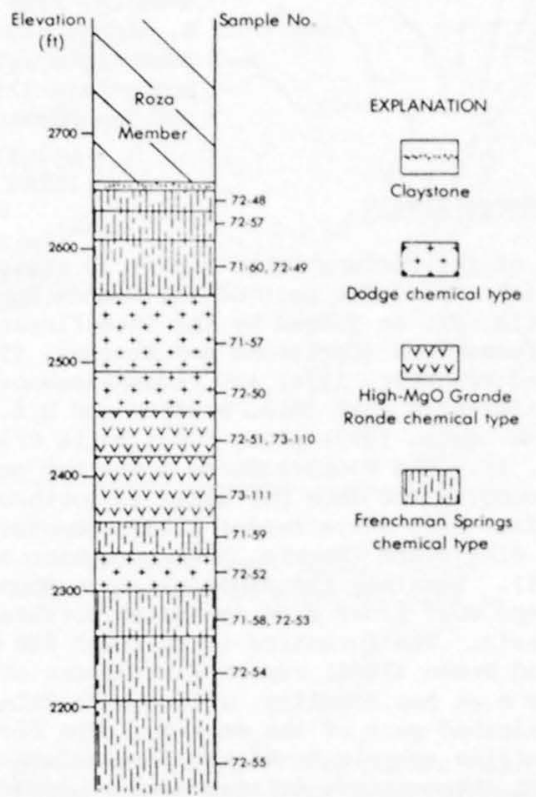

Figure 4. Schematic stratigraphic section in Benjamin Gulch, $3 \mathrm{~km}$ south of Pomeroy, washington, showing chemical types for 13 basalt flows. Note interbedded nature of chemically different flows. Uncorrected for north dip of about 4 degrees. From Swanson and others (1979b). 
[Averages include analyses available through March 1977; see wright and others (1979) for more recent averages and further discussion of chemical types]

\begin{tabular}{|c|c|c|c|c|c|c|c|c|c|c|c|c|c|c|c|c|}
\hline Chemical type & 1 & 2 & 3 & 4 & 5 & 6 & 7 & 8 & 9 & 10 & 11 & 12 & 13 & 14 & 15 & 16 \\
\hline Oxide & (7) $1 /$ & (44) & (21) & (68) & (7) & (8) & (4) & (13) & (13) & (8) & $(10)$ & (9) & $(20)$ & (4) & (8) & (35) \\
\hline $\mathrm{SiO}_{2}$ & 50.99 & 51.14 & 51.18 & 49.53 & 50.73 & 50.36 & 51.46 & 51.57 & 53.78 & 55.94 & 54.37 & 50.01 & 52.13 & 54.80 & 52.29 & 51.19 \\
\hline $\mathrm{Al}_{2} \mathrm{O}_{3}$ & 15.42 & 15.06 & 14.06 & 16.34 & 17.10 & 15.54 & 15.39 & 13.87 & 14.45 & 14.04 & 15.28 & 17.08 & 15.41 & 13.86 & 13.21 & 14.07 \\
\hline "FeO" 2/ & 12.24 & 13.04 & 14.11 & 12.38 & 11.26 & 11.25 & 12.46 & 12.28 & 11.35 & 11.77 & 9.46 & 10.01 & 10.66 & 13.32 & 14.38 & 13.91 \\
\hline MgO & 5.94 & 5.07 & 4.60 & 6.06 & 5.42 & 6.68 & 4.86 & 4.44 & 5.25 & 3.36 & 5.91 & 7.84 & 5.92 & 2.84 & 4.04 & 4.39 \\
\hline $\mathrm{CaO}$ & 10.11 & 9.31 & 8.59 & 9.15 & 9.30 & 10.67 & 9.45 & 8.12 & 9.07 & 6.88 & 9.79 & 11.01 & 10.18 & 6.48 & 7.90 & 8.48 \\
\hline $\mathrm{Na}_{2} \mathrm{O}$ & 2.55 & 2.58 & 2.65 & 2.58 & 2.45 & 2.95 & 3.29 & 3.36 & 2.83 & 3.14 & 2.80 & 2.44 & 3.00 & 3.18 & 2.67 & 2.72 \\
\hline $\mathrm{K}_{2} \mathrm{O}$ & 0.53 & 0.91 & 1.19 & 0.93 & 0.85 & 0.57 & 0.74 & 2.02 & 1.05 & 1.99 & 0.77 & 0.27 & 0.68 & 1.87 & 1.41 & 1.22 \\
\hline $\mathrm{TiO}_{2}$ & 1.66 & 2.24 & 2.93 & 2.41 & 2.32 & 1.56 & 1.79 & 2.71 & 1.78 & 2.27 & 1.17 & 1.00 & 1.48 & 2.46 & 3.17 & 3.13 \\
\hline $\mathrm{P}_{2} \mathrm{O}_{5}$ & 0.34 & 0.42 & 0.48 & 0.41 & 0.38 & 0.22 & 0.33 & 1.39 & 0.28 & 0.43 & 0.29 & 0.19 & 0.35 & 0.93 & 0.71 & 0.67 \\
\hline Mno & 0.22 & 0.22 & 0.22 & 0.20 & 0.19 & 0.20 & 0.23 & 0.24 & 0.19 & 0.19 & 0.16 & 0.14 & 0.19 & 0.26 & 0.22 & 0.23 \\
\hline Tota $3 /$ & $\overline{100.00}$ & 99.99 & $\overline{100.00}$ & $\overline{100.00}$ & $\overline{100.00}$ & $\overline{100.00}$ & $\overline{100.00}$ & $\overline{100.00}$ & $\overline{100.01}$ & $\overline{100.01}$ & 100.00 & $\overline{99.99}$ & $\overline{100.00}$ & $\overline{100.00}$ & $\overline{100.00}$ & 100.01 \\
\hline Chemical type & 17 & 18 & 19 & 20 & 21 & 22 & 23 & 24 & 25 & 26 & 27 & 28 & 29 & 30 & 31 & \\
\hline Oxide & (15) & (55) & (13) & (11) & (6) & (3) & (2) & (12) & $(30)$ & (41) & (8) & (12) & (13) & (8) & $(24)$ & \\
\hline $\mathrm{SiO}_{2}$ & 50.27 & 50.09 & 54.70 & 54.41 & 50.72 & 52.12 & 49.75 & 54.16 & 51.88 & 51.08 & 54.46 & 47.45 & 48.73 & 47.50 & 50.44 & \\
\hline $\mathrm{Al}_{2} \mathrm{O}_{3}$ & 13.69 & 14.31 & 14.10 & 14.51 & 16.23 & 14.33 & 15.26 & 13.84 & 14.88 & 13.54 & 14.29 & 13.84 & 13.88 & 12.50 & 14.07 & \\
\hline "FeO" 2 & 15.04 & 13.78 & 12.63 & 11.07 & 9.64 & 11.64 & 11.82 & 12.60 & 10.55 & 14.75 & 11.05 & 15.22 & 14.41 & 17.53 & 13.78 & \\
\hline MgO & 4.29 & 5.18 & 2.71 & 4.51 & 8.19 & 5.58 & 7.10 & 3.91 & 6.96 & 4.28 & 4.85 & 5.99 & 5.88 & 4.41 & 5.01 & \\
\hline $\mathrm{CaO}$ & 8.31 & 8.88 & 6.14 & 8.32 & 10.70 & 9.64 & 10.13 & 7.71 & 10.67 & 8.34 & 8.54 & 9.71 & 9.72 & 8.80 & 8.67 & \\
\hline $\mathrm{Na}_{2} \mathrm{O}$ & 2.67 & 2.57 & 3.20 & 2.69 & 2.22 & 2.69 & 2.32 & 2.66 & 2.36 & 2.45 & 2.75 & 2.31 & 2.42 & 2.44 & 2.79 & \\
\hline $\mathrm{K}_{2} \mathrm{O}$ & 1.16 & 1.07 & 2.68 & 1.77 & 0.51 & 0.87 & 0.46 & 1.70 & 0.64 & 1.25 & 1.39 & 0.72 & 0.73 & 1.23 & 1.47 & \\
\hline $\mathrm{TiO}_{2}$ & 3.55 & 3.15 & 2.80 & 1.95 & 1.45 & 2.48 & 2.42 & 2.82 & 1.62 & 3.52 & 2.17 & 3.62 & 3.30 & 3.79 & 2.90 & \\
\hline $\mathrm{P}_{2} \mathrm{O}_{5}$ & 0.81 & 0.78 & 0.88 & 0.56 & 0.18 & 0.49 & 0.55 & 0.41 & 0.25 & 0.59 & 0.35 & 0.91 & 0.73 & 1.54 & 0.66 & \\
\hline $\mathrm{MnO}$ & 0.21 & 0.19 & 0.17 & 0.21 & 0.17 & 0.17 & 0.21 & 0.19 & 0.17 & 0.20 & 0.15 & 0.23 & 0.20 & 0.27 & 0.21 & \\
\hline Total $3 /$ & $\overline{100.00}$ & $\overline{100.00}$ & $\overline{100.01}$ & $\overline{100.00}$ & $\overline{100.01}$ & 100.00 & 100.02 & 100.00 & 99.98 & $\overline{100.00}$ & 100.00 & $\overline{100.00}$ & 100.00 & $\overline{100.01}$ & $\overline{100.00}$ & \\
\hline
\end{tabular}

$1 /$ Number of analyses used in computing average

$\underline{2} / \mathrm{FeO}+0.9 \mathrm{Fe}_{2} \mathrm{O}_{3}$

3/Difference between total and 100 is due to rounding during normalization

Chemical types (defined by method of wright and Hamilton, 1978)

1. Picture Gorge (Imnaha Basalt)

2. American Bar (equivalent to the high-Ti Picture Gorge chemical

type of Wright and others, 1973)

3. Frenchman Springs (Imnaha Basalt)

4. Rock Creek

5. Fall Creek (Kleck, 1976)

6. High Mg-Picture Gorge (Wright and others, 1973)
7. Low Mg-Picture Gorge (Wright and others, 1973)

8. Prineville (recalculated from Uppuluri, 1974)

9. High Mg-Grande Ronde (one flow)

10. Low Mg-Grande Ronde (one flow)

11. Very high $\mathrm{Mg}-\mathrm{Gr}$ ande Ronde (one flow)

12. Robinette Mountain

13. Dodge

14. Shumaker Creek

15. Frenchman Springs (one flow)

16. Roza

17. Rosalia
18. Lolo

19. Umatilla

20. Wilbur Creek

21. Asotin

22. Slippery Creek

23. Lewiston Orchards

24. Esquatzel

25. Pomona

26. Elephant Mountain

27. Buford

28. Basin City

29. Martindale (Ice Harbor 1)

30. Goose Island (Ice Harbor 2)

31. Lower Monumental 
Table 2. Average trace-element compositions for chemical types in the Yakima Basalt Subgroup

[Instrumental neutron activation analyses by L.J. Schwarz under direction of J.J. Rowe]

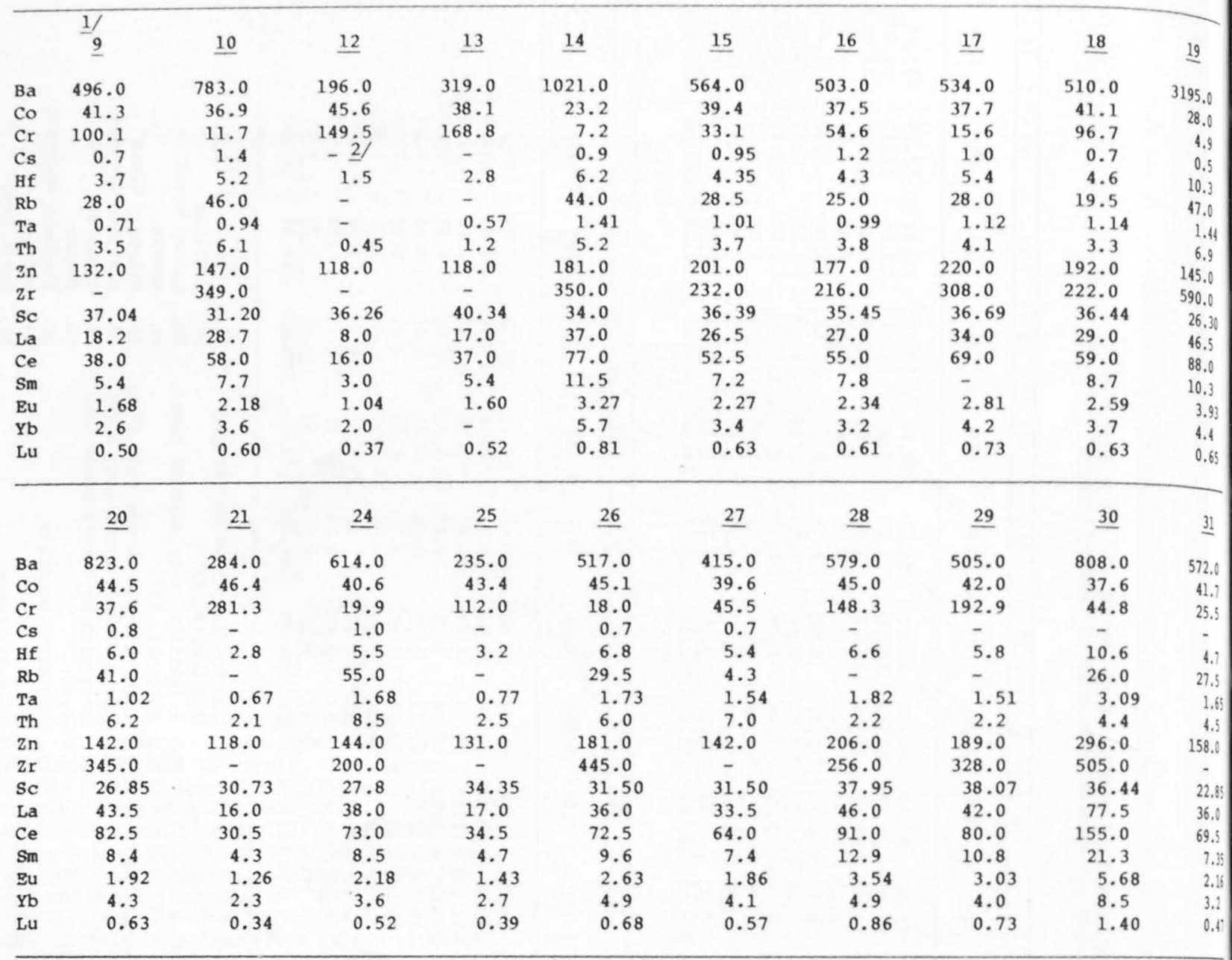

1/Chemical types:

$\begin{array}{ll}\text { 9. High-Mg Grande Ronde (one flow) } & \text { 15. Frenchman Springs } \\ \text { 10. Low-Mg Grande Ronde (one flow) } & 16 . \text { Roza } \\ \text { 12. Robinette Mountain } & 17 . \text { Rosalia } \\ \text { 13. Dodge } & 18 . \text { Lolo } \\ \text { 14. Shumaker Creek } & \text { 19. Umatilla }\end{array}$

20. Wilbur Creek

21. Asotin

24. Esquatze1

25. Pomona

26. Elephant Mountain 31
27. Buford

28. Basin City

29. Martindale

30. Goose Islan Lower Monumental

\section{2/Dash means not determined}

ette Mountain, is diktytaxitic and contains the lowest $\mathrm{K}_{2} \mathrm{O}$ and incompatible trace element concentrations of any other flow in the Yakima Basalt subgroup (tables 1 and 2); it was erupted from a long fissure south of Dayton, Washington. Several flows and dikes of the next youngest flow--the basalt of Dodge, a very coarse-grained plagioclase-phyric, grusy-weathering unit--form excellent markers in the Blue Mountains. The basalt of Dodge is chemically similar to but much coarser and more porphyritic than some high-Mg flows of the Grande Ronde Basalt (tables 1 and 2). The basalt of Shumaker Creek, the youngest unit in the member, is neither widespread nor easily recognized in the field, although its high $\mathrm{K}_{2} \mathrm{O}$ and $\mathrm{P}_{2} \mathrm{O}_{5}$ are distinctive (tables 1 and 2 ).
The Prenchman Springs Member overlies and locali interfingers with the Eckler Mountain Member and crops out widely in the central and western parts of the plateau (fig. 5A). Its volume is probably 3000 to $5000 \mathrm{~km}^{3}$. Generally three to six flows, in places as many as ten, occur in any one section. Plows were erupted from north-northwest-trending dikes extending through the Walla Walla area of southeast Washington (Swanson and Wright, 1978; Met son and others, 1979b, 1980). Highly porphyritic flows near Soap Lake at the southern end of Grand coulee may have er upted along the northward extensit of the known feeder system. Most flows of the Prenchman Springs Member contain rare to abundant glomerocrysts of plagioclase, although some are 


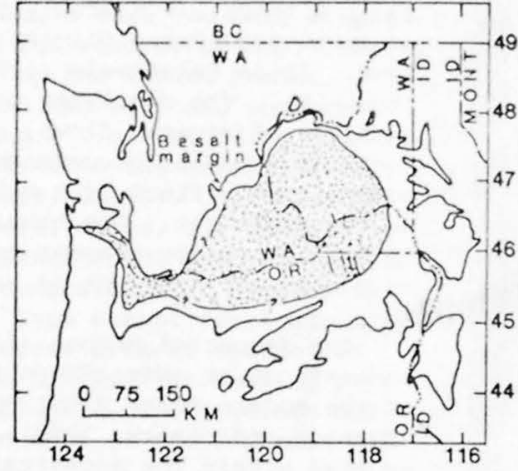

Frenchman Springs Member

A

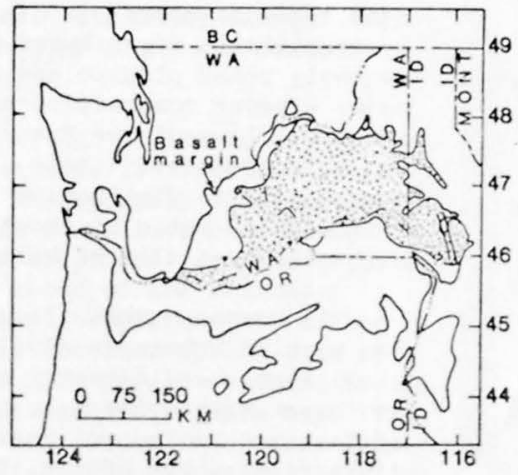

Priest Rapids Member

C

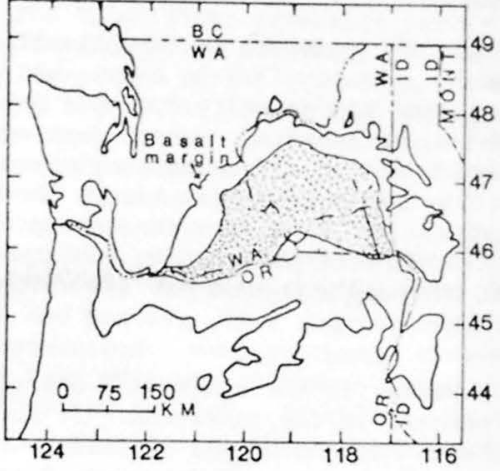

Roza Member

\section{B}

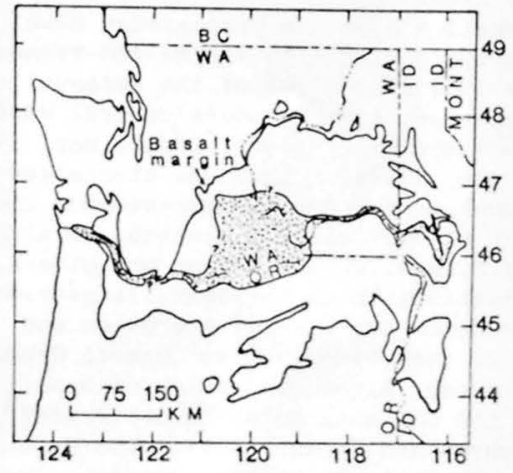

Pomona Member

D

Figure 5. Maps showing generalized distribution and feeder dikes for the Frenchman Springs, Roza, and Priest Rapids Members of the Wanapum Basalt and the Pomona Member of the Saddle Mountains Basalt. From Swanson and Wright (1978, fig. 3.5).

aphyric and indistinguishable in the field from some flows of Grande Ronde Basalt. The member has a high $\mathrm{FeO}$ and $\mathrm{TiO}_{2}$ composition known as Frenchman Springs chemical type (tables 1 and 2 ). The ${ }^{87} \mathrm{Sr} / 86 \mathrm{Sr}$ initial ratio is about .7053 (McDougall, 1976). The Frenchman Springs is overlain by the Roza Member.

The Roza Member, a highly plagioclase-phyric unit with a volume of about $1500 \mathrm{~km}^{3}$, is well known, and readers are referred to papers by Lefebvre (1970) and Swanson and others $(1975$; 1979b) for details. The member was erupted from a linear vent system more than $165 \mathrm{~km}$ long in the eastern part of the plateau (fig. 5B). The Roza consists principally of two cooling units, although more thin units occur near the vent system. The composition of the Roza is similar to that of the Frenchman Springs Member although on the average slightly richer in MgO (tables 1 and 2). Its ${ }^{87} \mathrm{Sr} / 86 \mathrm{Sr}$ initial ratio is about .7054 (McDouga 11, 1976).

The Priest Rapids Member overlies the Roza Member and is the youngest basalt throughout most of the northern part of the Columbia Plateau. The member occurs as far southwest as the Columbia Gorge (fig. 5C). All known feeder dikes are confined to the far eastern part of the province. Several dikes occur near Orofino, Idaho, and along Slate Creek about 16 $\mathrm{km}$ east of Freedom, Idaho (W.H. Taubeneck, T.L.
Wright and D.A. Swanson, unpub. chemical data, 1977; V.E. Camp in Swanson and others, 1979a), and probable vents are located near Emida, Idaho, and in Palouse, Washington. Other vents presumably exist in northern Idaho, as intracanyon flows of the member occur far up the ancestral St. Joe River valley. The estimated volume of the Priest Rapids is $2000-3000 \mathrm{~km}^{3}$. In and near Spokane, flows of the Priest Rapids Member fill valleys as much as $100 \mathrm{~m}$ deep eroded into the main part of the Latah Formation, a sequence of finegrained clastic sediments interbedded with and overlying the Grande Ronde Basalt. Flows of the Priest Rapids invade sediments of the Latah in many places near Spokane as well as other sediments near Orofino, Idaho. The Priest Rapids Member contains magnetically reversed flows of two distinctly different compositions, a very high $\mathrm{FeO}$ and $\mathrm{TiO}_{2}$ type (Rosalia chemical type) and a high Mgo type (Lolo chemical type) (tables 1 and 2). The flows of Rosalia chemical type are found throughout most of the extent of the member and are consistently older than those of Lolo chemical type, which are confined to the southern two-thirds of the member's outcrop area. A few thin flows of different compositions occur near vent areas in nor thern Idaho and adjacent Washington. McDougall (1976) obtained an ${ }^{87} \mathrm{Sr} / 86 \mathrm{Sr}$ initial ratio of .7053 on a flow of Rosalia chemical type near Frenchman Springs Coulee. 


\section{Saddle Mountains Basalt}

This formation, the youngest in the Columbia River Basalt Group, is about 13.5 to $6 \mathrm{~m} . y$. old and contains flows erupted sporadically during a period of waning volcanism, deformation, canyon cutting, and development of thick but local sedimentary deposits between flows. The Saddle Mountains Basalt has a volume of only about $3000 \mathrm{~km}^{3}$, less than one percent of the total volume of basalt, yet contains by far the greatest chemical and isotopic diversity of any formation in the group.

The Umatilla Member is the oldest and one of the most extensive members in the formation. It occurs in extreme southeast Washington and northwest oregon (the Troy and Lewiston basins and Uniontown Plateau) (Price, 1977; Ross, 1978; Swanson and others, 1980); vent areas and a feeder dike occur in the puffer Butte area (fig. 1; Price, 1977). Remnants of the Umatilla fill a broad shallow paleovalley leading from the Troy basin across the present-day Blue Mountains in northern oregon to the Milton-Freewater area, where the flow spread out of the paleovalley as a sheet flood covering much of south-central Washington (D.A. Swanson and T.L. Wright, unpub. map, 1978; Swanson and others, 1979a). Lava was channelleo along some canyons eroded during post-Wanapum time in the western part of the Columbia Plateau, as along Yakima Ridge (R.D. Bentley in Swanson and others, 1979a). The distribution of the Umatilla provides the earliest evidence for extensive erosion and canyon-cutting of the Columbia River Basalt Group on the Columbia plateau, although erosion of basalt was substantial in the Columbia Gorge betore priest Rapids time (Beeson and Moran, 1979). The Umatilla has an unusual chemical composition characterized by lower contents of $\mathrm{CaO}$ and $\mathrm{MgO}$ and higher contents of $\mathrm{Na}_{2} \mathrm{O}, \mathrm{K}_{2} \mathrm{O}$, and incompatible trace elements than most other flows in the group (tables 1 and 2). The content of $\mathrm{Ba}$ is $2000 \mathrm{ppm}$ or more, sufficient alone to identify the member. F.R. Hooper loral commun. 1979) has recognized two flows of slightly different $\mathrm{K}_{2} \mathrm{O}, \mathrm{TiO}_{2}$ and $\mathrm{Ba}$ contents in the member. The ${ }^{87} \mathrm{Sr} / 86 \mathrm{Sr}$ initial ratio of the Umatilla is high. about . 7092 (McDougall, 1976). The Umatilla underlies the Wilbur Creek Member.

The Wilber Creek Member and the overlying Asotin Member, distinctly different flows but possibly chemically related, were apparently erupted in the clearwater embayment of Idaho. From there, the flows advanced down valleys and gorges leading from the Uniontown Plateau to the central part of the Columbia Plateau; remnants of the valley-filling flows occur east and west of lower Cow Creek (fic. 1), near warden and Othello, and elsewhere (Swanson and others, 1980). The flows crossed the northern part of the Pasco Basin (Myers and price, 1979) and movec down a canyon along Yakima Ridge possibly as far west as Yakima (R.D. Bentley in Swanson and others. 1979a). The flows overlie quartzitic gravel of extra-plateau derivation along Yakima Ridge and trace a westward course of the ancestral Columbia River from the Pasco Basin to Yakima. The Wilbur Creek has a major element composition similar to that of the intermediate-Mg Grande Ronde chemical type, and the Asotin is similar to the basalt of Robinette Mountain (table 1); however, trace element compositions easily discriminate the flows (table 2).

The Weissenfels Ridge Member overlies the Asotin Member and contains several flows confined mainly to the Lewiston Basin and presumably erupted there. The basalt of Lewiston Orchards, one flow averaging 10-15 $\mathrm{m}$ thick, is sparsely plagioclase-phyric and contains groundmass olivine visible with a hand lens. It is relatively rich in $\mathrm{MgO}$ and poor in $\mathrm{kgO}$ (table 1). The overlying basalt of slippery Creek consists of several flows, at least one of which contains abundant groundmass olivine. Its chemical composition differs from other flows of the Saddle Mountains Basalt. The basalt of Anatone (Price, 1977) has a major element composition similar to the Lolo chemical type but is enriched in light REE.

The Esquatzel Member (fig. 2) occurs as isolated remnants of an intracanyon flow along and just north of the modern Snake River upstream from Devils Canyo (Swanson and others, 1980). It apparently was erupted within the ancestral Snake drainage, flowed downcanyon, and entered the ancestral Columbia River valley in the central part of the plateau. The Esquatzel then flowed along Yakima Ridge in a course similar to that of the Wilbur Creek and Asotin Members. The Esquatzel is distinguished petrographically by irregularly distributed phenocrysts and clots of strongly zoned plagioclase and clinopyroxene. Its major element composition can be confused with some low- $\mathrm{TiO}_{2}$ flows of the Frenchman Springs Member of the Wanapum Basalt (table 1), but its trace element composition is distinctive (table 2) and its ${ }^{87} \mathrm{Sr}$ / ${ }^{86} \mathrm{Sr}$ initial ratio of about .7146 extraordinarily high (the Mesa flow of Nelson and others, 1976).

The Pomona Member (fig. 2), well known through the work of Schmincke $(1967 \mathrm{~b})$, occurs across the province from the Clearwater embayment in Idaho to southwest washington near the coastline (the basalt of Packsack Lookout of Snavely and others, 1973), a distance of about $500 \mathrm{~km}$ (fig. 5D). The member, probably consisting of only one flow, was apparentiy erupted about $12 \mathrm{~m} . \mathrm{y}$. aqo in the Clearwater embayment; V.E. Camp (in Swanson and others, 1979a) located feeder dikes northeast of Orofino, Idaho, for a flow probably correlative with the pomona. It flowed out of the embayment down an ancestral Snake River canyon, virtually coincident with the modern canyon, to the central plateau, where it spread out as a broad sheet covering much of south-central Washington and extreme north-central oregon. The member advanced along the ancestral Columbia River westward along Yakima Ridge to the site of Yakima. It can readily be traced as far west as Mosier, Oregon, in the Columbia Gorge. Pron there, its pathway to southwest washington is unclear, but it presumably followed an ancestral Columbia drainage systen much as earlier flows did. Peperites and invasive flows formed along the margin of the flow where it plowed into sediments, and a fused vitric tuff underlies the flow in many other places (Schmincke, 1967c). The Pomona, with a volume of more than $600 \mathrm{~km}^{3}$, is one of the most voluminous single flows in the group. It has a distinctive chemical composition (tables 1 and 2) and petrography (Schmincke, 1967b) and represents one of the best markers on the Columbia plateau. Its ${ }^{87} \mathrm{Sr} /{ }^{86} \mathrm{Sr}$ initial ratio is about .7078 (Nelson and others, 1976; McDougall, 1976).

The Elephant Mountain Member (fig. 2) was probably erupted in part from a dike mapped by Ross (1978) in the Troy basin of nor theast Oregon, where it is known as the Wenaha flow of walker (1973b) Flows of the member advanced down the ancestral Snake River canyon as the Pomona Member had done about 1.5 m.y. earlier. The flows spread outward from the mouth of the canyon near Mesa, Washington, and covered much of south-central Washington, in many place: 
capping volcaniclastic debris that had been erupted in the cascades, carried eastward by rivers, lahars, ind winds, and deposited on the Pomona Member. Recent mapping has defined the west and southwest nargin of the member along a line extending approxinately southward from Yakima to the Horse Heaven nately (Swanson and others, 1979a). The Elephant rountain consists of several flows, all chemically similar, of normal and transitional magnetic polarity. Its major element composition is similar to that of Rosalia chemical type except for lower

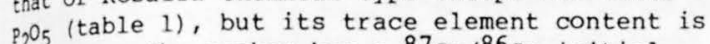
distinct. The member has a ${ }^{87} \mathrm{Sr} /{ }^{86} \mathrm{Sr}$ initial ratio of about .7078 (McDouga11, 1976; Nelson and others, 1976), similar to that of the Pomona.

The Buford Member (fig. 2), a single magnetically reversed flow 20-30 m thick, is the youngest known basalt on the plateau surface of extreme southeast washington and northeast Oregon, where it is confined and presumably was erupted. Its major-element composition shows distinctly higher light REE contents (table 2).

The Ice Harbor Member (fig. 2), dated as about 8.5 m.y. old (McKee and others, 1977), was erupted from the central part of the Columbia Plateau, where dikes and remnants of vent areas have been recognized. The last previous eruptions from the central part of the plateau were those of the Frenchman springs Member, about $6 \mathrm{~m}, \mathrm{y}$. before the Ice Harbor volcanism. Most flows are confined to the area of venting, but at least one flow spread westward to the Richland area and southwestward to Wallula Gap. The Ice Harbor Member can be subdivided into three readily mappable units of different compositions (tables 1 and 2). The lowest unit--the basalt of Basin city--contains plagioclase and olivine phenocrysts, has normal magnetic polarity, and is chemically distinct. The middle unit--the basalt of Martindale-carriers clots and single crystals of clinopyroxene, - plagioclase, and olivine and has reversed magnetic polarity; two related compositions characterize the Martindale (Helz, 1978), the dominant of which is listed in table 1. The upper unit--the basalt of Goose Island--contains sparse plagioclase and magnetite phenocrysts, has normal magnetic polarity, and has the most Fea-rich composition of any known flow in the group (and one of the most FeO-rich compositions of any terrestrial basalt). The three informal units have a similar ${ }^{87} \mathrm{Sr} /{ }^{86} \mathrm{Sr}$ initial ratio of about .7077 (Helz, 1978). Helz (1978) has recently completed an exhaustive experimental and petrogenetic study of the Ice Harbor Member. The Ice Harbor vent system is about $90 \mathrm{~km}$ long and has strong aeromagnetic expression (Swanson and others, 1979c).

The Lower Monumental Member, about $6 \mathrm{~m} . \mathrm{y}$. old, is the youngest member in the Saddle Mountains Basalt. It is confined to the modern Snake River Canyon between Devils Canyon and Asotin, Washington, a distance of about $150 \mathrm{~km}$. Its source was presumably near Asotin or farther east but has not yet been identified. Its chemical composition is similar to iolo chemical type, although slightly higher in alkalles and markedly higher in light REE (tables 1 and 2). The Lower Monumental has a high

${ }^{87} \mathrm{Sr} /{ }^{86} \mathrm{Sr}$ initial ratio of about .7109 (Nelson and others, 1976)

\section{PHYSICAL CHARACTERISTICS OF FLOWS}

Plows within the Grande Ronde, Wanapum, and Saddle Mountaine Basalts range from a few tens of centineters to more than $100 \mathrm{~m}$ thick. averading 30-40 $m$. The thick flows generally record ponding in prebasalt valleys, in structurally controlled basins that developed during volcanism, or in narrow canyons eroded into older flows; such intracanyon flows are common only in the Saddle Mountains Basalt. Even the thinner flows generally show evidence of having ponded. This evidence consists of the columnarjointed nature of the basalt (fig. 6). Such columns can apparently form only under static cooling conditions; their development therefore implies that the lava had ponded. What impounded the lava can rarely be determined. Natural levees several meters high have been observed in places and probably account for most of the ponding. Elsewhere, flows could have pinched out against opposed topographic slopes.

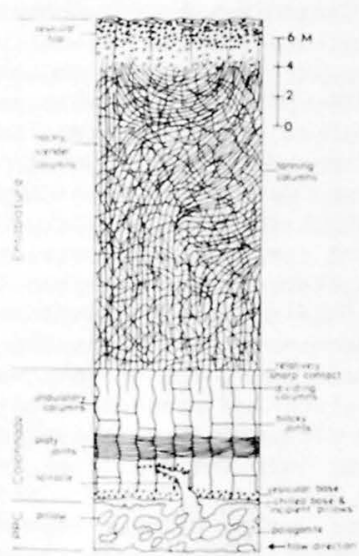

Figure 6. Cross section of flow in Yakima Basalt Subgroup, showing, in idealized form, jointing patterns and other structures. PPC, pillow palagonite (hyaloclastite) complex, present at base or throughout flows that entered water.

Flows that cooled under stagnant conditions contracted and developed a characteristic jointing habit, shown in idealized form in figure 6 . The terms colonnade and entablature were borrowed from classical architectural usage by Tomkeieff (1940). Columns in the colonnade are from $10 \mathrm{~cm}$ to $5 \mathrm{~m}$ in diameter, averaging about $1 \mathrm{~m}$, and can be as long as 50-75 $\mathrm{m}$ although generally 5-10 m. Most are straight, but curved columns are rather common and generally unexplainable in terms of simple cooling models. Columns in the colonnade are commonly subdivided into prismatic blocks by cross joints; the coarsest-grained part of a flow may be platy owing to the close spacing of cross joints.

The colonnade-entablature contact is relatively sharp, the change commonly taking place within 1-2 $\mathrm{cm}$. The contact is traceable in many places for several kilometers before other complexities obscure it. The glass content of the groundmass increases abruptly from the colonnade to the entablature for an unknown reason (Swanson, 1967; Long, 1978). The entablature consists of columns of smalier diameter. denerally less than $25 \mathrm{~cm}$, and less consistent or:entation than those in the colonnade. Colunns in many entablatures are bundled into fans, synforms, tents, or other unusualiy shaped arrancements. Most columns in an entablature are highly seqmented hy irreqular cross joints, so that the columns can os readily oroken into fist-size pieces. The entableture generally comprises about 70 percent of the 
thickness of a flow but can make up 100 percent (one example that we know of) to zero percent. The upper part of the entablature is scoriaceous and commonly merges into a zone of short, wide, generally poorly defined columns that some workers call the upper colonnade. A rubbly, clinkery zone occurs above the entablature of some flows. Such a zone is absent from the base of flows. The origin of this rubbly zone is in question. The rubble is, in our experience, more common near vent areas than elsewhere; this observation suggests that the rubble may represent material thrown out of the vent near the end of eruption and modified during movement of the flow.

Idealized jointing patterns can be satisfactorily explained by existing theory for the cooling of bodies of igneous rock (Jaeger, 1961), but such patterns are seldom found in nature. Acceptable thermomechanical explanations for the typically complex jointing patterns, particularly in the entablature, are not available despite considerable descriptive information (Tomkeieff, 1940; Waters, 1960; Mackin, 1961; Spry, 1962; Swanson, 1967; Schmincke, 1967b; Long, 1978; Ryan and Sammis, 1978). Complications related to the mutual interference between columns growing inward from irregular contacts, ponding of water on a flow surface and percolation down joint planes during solidification, the influence of chemical composition on tensile strengths and heat conduction, and inadequate knowledge of rock mechanics under high temperature-low pressure conditions are some of the difficulties that plague attempts at analysis of natural jointing habits.

Some flows have a tiered appearance defined principally by alternating layers of vesicular and relatively nonvesicular rock rather than by joints. These layers may record separate gushes or thin flows that piled up and solidified as a single compound cooling unit. Tiers much more commonly occur in entablatures than colonnades.

The upper surface of a flow is rarely exposed in plan view. Where seen, the surface is rather flat, smooth, filamented, and locally ropy--surface features characteristic of lava ponds at kilauea. The surface of a flow with a rubbly upper zone is rough, has a relief of as much as $6 \mathrm{~m}$, and otherwise appears unlike typical surfaces of ponded flows.

Many flows entered water and formed pillows. Recent studies (Jones, 1968; Moore, 1975) have demonstrated conclusively that pillows are nothing more than the subaqueous equivalent of pahoehoe toes. Many of the pillowed flows occur near the margin of the plateau as it existed at the time of eruption, apparently because lakes were formed as flows ponded rivers draining from marginal highlands. Other pillowed flows are much more extensive, perhaps signifying entry into shallow lakes standing on the plateau surface. One such extensive flow, in the priest Rapids Member, is pillowed throughout an area of tens of square kilometers in the Cheney-Palouse scabland southwest of spokane.

In places, lava deltas (Fuller, 1931; Moore and others, 1973) formed as lava poured into shallow lakes and ponded streams. The direction of dip of foreset "bedding" defined by elongate pillows and thin sheet flows in the lava deltas indicates the local flow direction of the lava. Particularly good examples of lava deltas can be seen near Malden south of Spokane (Griggs, 1976), near the mouth of Moses Coulee (Fuller, 1931), and at the mouth of Sand Hollow south of Vantage.
Other criteria for defining flow directions include inclined pipe vesicles, which plunge upcurrent, and bent spiracles (fig. 6), formed by steam blasts beneath a flow, which tail out down-current, Flow directional data for basalts must be treated in the same way as those for current-produced structures in sedimentary rocks--carefully. A few data in a small area show the local direction but say little about regional patterns. Nonetheless, careful studies by Schmincke (1967a) and on-going work by others are succeeding in defining patterns of lava advance within the plateau.

\section{FEEDER DIKES, VENT SYSTEMS, AND ERUPTION}

One of the major results of recent mapping has been identification of sources for most stratigraphic units and even single flows. Feeder dikes have been found for flows in all formations and members of the Columbia River Basalt Group except the Wilbur Creek, Asotin, Esquatzel, Buford, and Lower Monumental Members of the Saddle Mountains Basalt. The feeder dikes average about $8 \mathrm{~m}$ wide but vary from a few centimeters to more than $60 \mathrm{~m}$. They may tend to thin upward, but this is far from certain. The dikes generally trend north to north-northwest. They cannot be traced far along strike, in part because of exposure problems. Obviously related dike segments, offset a few meters to form an en echelon pattern, form systems extending tens of kilometers. Compound or multiple dikes, consisting of two or more pulses of magma related to the same intrusive event, are common, but composite dikes, containing two or more phases of contrasting compositions, have not been reported. In other words, each fissure was used just once, not repeatedly.

The chance of finding a dike connecting with a flow it fed is small, owing to problems of exposure. Nonetheless, several dikes have been found displaying such a connection. The top of most such dikes is rubbly, apparently consisting of slabs of crust once floating on a flow before it poured back into the fissure (for example, Plate la in Swanson and others, 1975). In one dike lacking such rubble, the dike merges imperceptibly with its flow of the Frenchman Springs Member (fig. 1, number 6, Swanson and others, 1975).

Many other dikes can be inferred to correlate with particular flows, or at least sequences of flows, on the basis of chemical composition and magnetic polarity. In this way, feeders have been identified for most of the named stratigraphic units.

The shape and extent of vent systems for specific flows or related sequences of flows can be reconstructed from the locations of feeder dikes, thick piles of degassed flows (presumably near their vent), abundant collapsed pahoehoe (Swanson, 1973), and accumulations of basaltic tephra (in places occurring in still recognizable spatter cones and ramparts). Such reconstructions show that eruptions of single flows or related flows took place from fissures concentrated in long, narrow vent systems on the order of tens of kilometers long and several kilometers wide (Swanson and others, 1975, and later work).

Vent systems for the Grande Ronde Basalt are distributed across the eastern half to two-thirds of the Columbia Plateau, but those for other units are more restricted (Swanson and Wright, 1979). For example, feeder dikes for the Picture Gorge Basalt are confined within the John Day Basin and neighboring areas, those for the Frenchman Springs Member within 
me $60 \mathrm{~km}$ wide and probably more than $200 \mathrm{~km}$ long the for the Ice Harbor Member within a zone 15 no tho and about $90 \mathrm{~km}$ long. On a still finer aide ant systems for specific flows are nearly cale, vent they occur along single dikes or closely inear, as thed dikes. Examples are the vent system the Roza Member (probably less than $5 \mathrm{~km}$ wide and known to be more than $165 \mathrm{~km}$ long Swanson and a known the sas lt of Robinette Mountain in the Eckler Mountain (a single dike extending at least $25 \mathrm{~km}$ across (e) Blue Mountains), the basalt of Basin City in the the Harbor Member (possibly a single dike at least 50 (ong), and several chemically distinct flows in a Grande Ronde Basalt (T.L. Wright and D.A. Swansn, unpub. data, 1978).

Knowledge of the geometry of the vent systems not ly allows prediction of where vents for specific llows should occur once one such vent is found but iso further provides important constraints regarding gata generation, storage, and eruption mechanics. sing such knowledge, attempts have been made to stimate the rates of eruption and advance for single flows. The estimates take into account the

observation that flows, even those that advanced tens in hundreds of kilometers from their sources, wenched to a crystal-poor sideromelane glass when they entered water; this indicates little cooling buring transport and hence rapid advance, since the lava apparently moved as sheet floods rather than through insulating tube systems. Application of theologic models, developed in part from this obserration by Shaw and Swanson (1970), to vent systems of know dimensions suggests eruption rates of about 1 $\mathrm{c}^{3} /$ day per linear kilometer of active fissure for the largest flows, such as those in the Roza Member, and about $10^{-4} \mathrm{~km}^{3} /$ day $/ \mathrm{km}$ for the smaller flows (Svanson and others, 1975). For flows of "average" rolume, probably several tens of cubic kilometers, tates of $10^{-1}$ to $10^{-2} \mathrm{~km}^{3} /$ day $/ \mathrm{km}$ may be inferred. 8y comparison, sustained rates of eruption at Kilauea and Mauna Loa are $10^{-3}$ to $10^{-4} \mathrm{~km}^{3} /$ day $/ \mathrm{km}$.

vsing observed dike widths, theoretical modeling suggests that the high eruption rates could indeed have been sustained by supply from depth (Shaw and Svanson, 1970). Such eruptions probably lasted a few days. Flow rates of 5 to $15 \mathrm{~km} / \mathrm{hr}$ down slopes of 1:1000 are calculated from the model, adequate to allow thick flows to move far with little cooling.

Rapid eruption rates do not necessarily imply rapid melting rates in the mantle. Flows were erupted only once every ten thousand years or so in any one area on the plateau during even the peak of rolcanic activity (Grande Ronde time), as estimated by counting the number of flows in a magnetostratigraphic unit of assumed duration based on comparison vith seafloor magnetic anomalies of roughly comparwle age. Calculations show that continuous melting at the present Hawailan rate, $10^{-1} \mathrm{~km}^{3} / \mathrm{yr}$ (Swanson, 1972), could account for the volume of the Columbia River Basalt Group in the alloted time. Episodic rapid melting events ("flash melting") cannot be excluded but are not required.

If melting progressed at the Hawailan rate, then large, deep storage reservoirs are required in order 0 account for the large volume of single flows. Shis contrasts with the Hawailan situation, where eruptions are much more frequent and lava "leaks" to the surface more or less continuously. The presence f large, deep storage reservoirs, possibly in the pper mantle, may be a principal and distinguishing tharacteristic of flood-basalt provinces in general.

\section{CHEMICAL PETROLOGY OF THE YAKIMA BASALT SUBGROUP}

Two major geochemical breaks occur within the Yakima Basalt Subgroup. The older break separates a high- $\mathrm{SiO}_{2}$, low-FeO and $\mathrm{TiO}_{2}$ sequence below (Grande Ronde Basalt) from a relatively low- $\mathrm{SiO}_{2}$, high-FeO and $\mathrm{TiO}_{2}$ sequence (Wanapum Basalt). This chemical change took place over a short time, as magnetic stratigraphy is continuous across the break, $\mathrm{K}-\mathrm{Ar}$ ages above and below agree within analytical error for these rocks $\left( \pm 1 \mathrm{~m} . \mathrm{y}^{\prime}\right)$, and flows of different chemical types are locally interlayered (fig. 4). Trace-element levels are similar and $\mathrm{Sr}$ isotopic ratios are similar and relatively low (0.704-0.706) in both sequences. Major- and trace-element chemistry of the Grande Ronde Basalt, which makes up 75 percent of the volcanic pile, shows cyclic variation rather than an evolutionary trend.

The younger geochemical break, separating the Wanapum and Saddle Mountains Basalts, is marked by 1) increase in $\mathrm{Sr}$ isotopic ratios to $0.708-0.715$, and 2) greater abundance of most incompatible elements and steeper chrondrite-normalized REE patterns in those flows of the Saddle Mountains Basalt whose major oxide chemistry is similar to older flows. These changes took place over a relatively long time (.5-1 m.y.?), as there is evidence of erosion and deposition of sediments between the Wanapum and Saddle Mountains Basalts.

The Columbia River Basalt Group shows far less coherent chemical variation than is typical for ceanic tholeiites. Ratios of incompatible elements vary widely among the various formations as well as among flows belonging to the same formation. Enrichment factors differ for different incompatible elements in units which show smooth chemical variation trends. For example, the least magnesian flows of the Grande Ronde Basalt (Mgor 3 percent), have contents of $\mathrm{P}_{2} \mathrm{O}_{5}, \mathrm{Hf}, \mathrm{Ta}$, and LREE that are 2-3 times higher than in the most magnesian flows of the Grande Ronde (Mgar6 percent), whereas the enrichment of $\mathrm{Th}$ and $\mathrm{K}$ in these same flows is greater, about 3-4.

We make the following inferences as a start toward a model to explain the generation of magmas in the subgroup.

1. We infer that magma compositions are controlled principally by partial melting. Enrichment factors in the Grande Ronde Basalt are not consistent with a fractionation model in which crystallization of 55-70 percent of stored liquid would have to take place repeatedly. Mixing calculations fail to balance both major oxides and incompatible trace elements using any reasonable fractionating mineral assemblage.

\section{The scarcity of phenocrysts, absence of} high-pressure "megacrysts", and absence of fractionation or accumulation trends suggest that magmas accumulated near the site of melting and may have been superheated during transport to within a few kilometers of the surface.

3. We infer little or no high-level crustal storage for most of the magma, as evidenced by 1) absence of grabens or calderas associated with single flows of large volume and 2) absence of phenocrystrelated chemical fractionation or accumulation trends even between phyric and aphyric flows of the same stratigraphic unit. We feel that plagioclase phenocrysts present in spme flows may have formed during 
ascent of magma just prior to eruption and perhaps even after eruption.

4. If a partial melting model is accepted, melting must be relatively "wet" to yield quartz-normative magmas. Some metasomatic enrichment of trace elements is required to explain the incoherent ratios of incompatible elements and possibly the highest ${ }^{87} \mathrm{Sr} /{ }^{86} \mathrm{Sr}$ ratios.

5. Bulk-lava chemistry suggests that the source for most of the magma was relatively iron-rich and olivine-poor clinopyroxenite. The major chemical and stratigraphic units and many of the individual flows require chemically distinct source rocks. The overall source for magmas of the Columbia River Basalt Group must be heterogeneous both in space and through time.

\section{INVASIVE FLOWS}

Weakly consolidated sedimentary rocks, generally medium-grained sandstone to siltstone, occur between many flows near the margin of the plateau and between some of the younger flows in local structural basins on the plateau. The sedimentary rocks rest depositionally on the underlying flow in some places, but in many other places the contact relations show that subjacent basalt intrudes or invades the sediment. Schmincke (1967c) was one of the first to recognize this, and recent work has demonstrated how common such invasive relations are. We estimate that more than half of the observed contacts between basalt and sedimentary rocks on the Columbia plateau are invasive.

How are such contacts interpreted? Do they signify "normal" intrusive relations in which basaltic magma never reached the surface before solidifying as in classic dikes and sills, or are they formed as lava flows burrow into unconsolidated sediments accumulating on the ground surface (invasive flows of Byerly and Swanson, 1978)? Both processes produce similar results.

The key to proper interpretation lies in the stratigraphy. If the basalt is at its proper stratigraphic position relative to overlying flows, it almost certainly was a flow that invaded sediments at the ground surface. This is because thin sedimentary deposits, generally less than $10 \mathrm{~m}$ thick on the plateau, are light and hence exert little confining pressure; vesiculating magma rising and encountering such sediments would certainly blast through rather than spread laterally into them.

Mapping and chemical studies have shown that, in every example so far found on the plateau, the invasive basalt is at its expected stratigraphic position relative to overlying flows and hence is in invasive flow (Schmincke, 1967c; Camp, 1976; Byerly and Swanson, 1978; D.A. Swanson, G.R. Byerly and T.L. Wright, unpub. data, 1978). We include in this interpretation two thick sills previously interpreted conventionally, the Hammond sill of Hoyt (1961) near Wenatchee, Washington and the "Whiskey Creek sills" of Bond (1963). Work by Byerly and Swanson (1978 and unpub. data) and V.E. Camp (unpub. data, 1978) shows that even these thick sills, more than $120 \mathrm{~m}$ thick locally, are in proper stratigraphic position relative to overlying flows.

These conclusions are significant, because they show that invasive contacts provide insufficient, in fact totally misleading, evidence for the former presence of magma beneath the area. For example, invasive relations are particularly well displayed along the northwest margin of the plateau, where al other evidence negates the former presence of magma bodies; no intrusive contacts are found here in any situation other than one involving sediments, the invading flows are in their proper stratigraphic position relative to other flows, and flow directions show that surface flows moved toward, not away from, correlative sills. Invasive relations also demonstrate the unreliability of using sedimentary interbeds as stratigraphic guides on the columbia plateau. The basalt flows are always in their proper stratigraphic position, but the interbeds, at least fine-grained ones, are commonly not, owing to rafting by invasive flows.

\section{REFERENCES CITED}

Beeson, M.H., and Moran, M.R., 1979, Columbia River Basalt Group stratigraphy in western Oregon: Oregon Geology, v. 41, p. 11-14.

Berggren, W.A., and van Couvering, J.A., 1974, The Late Neogene: Biostratigraphy, geochronology, and paleoclimatology of the last 15 million years in marine and continental sequences: Palaeogeography, palaeoclimatology, Palaeoecology, v. 16, p. 1-216.

Bingham, J.W., and Grolier, M.J., 1966, The Yakima Basalt and Ellensburg Formation of south-central Washington: U.S. Geol. Survey Bull. 1224-G, 15 p.

Bond, J.G., 1963, Geology of the Clearwater embayment: Idaho Bur. Mines and Geol., pamphlet $128,83 \mathrm{p}$.

Brown, C.E., and Thayer, T.P., 1966, Geologic map of the Canyon City quadrangle, northeastern Oregon: U.S. Geol. Survey Misc. Geol. Invest. Map I-447 scale 1:250,000.

Byerly, Gary, and Swanson, Don, 1978, Invasive Columbia River basalt flows along the northwestern margin of the Columbia Plateau, north-central Washington: Geol. Soc. America Abstracts with Programs, v. 10, no. 3, p. 98 .

Camp, V.E., 1976, Petrochemical stratigraphy and structure of the Columbia River basalt, Lewiston Basin area, Idaho-Washington: Washington State Univ., Pullman, Ph.D. Dissert., $201 \mathrm{p}$.

Camp, V.E., Price, S.M., and Reidel, S.P., 1979, Descriptive summary of the Grande Ronde Basalt type section, Columbia River Basalt Group: Rockwell Hanford Operations Report RHO-BWI-LD-15, $24 \mathrm{p}$.

Cockerham, R.S., and Bentley, R.D., 1973, Picture Gorge and Yakima Basalt between $\mathrm{Clarno}$ and Butte Creek, Oregon: Geol. Soc. America Abstracts with Programs, v. 5, no. 2, p. 23.

Fruchter, J.S., and Baldwin, S.F., 1975, Correlations between dikes of the Monument swarm, central Oregon, and picture Gorge Basalt flows: Geol. Soc. America Bull., v. 86, p. 514-516.

Fuller, R.E., 1931, The aqueous chilling of basaltic lava on the Columbia River Plateau: Am. Jour. Sci., v. 21, p. 281-300.

Greeley, Ronald, 1977, Basaltic "plains" volcanism, in Greeley, Ronald, and King, J.S., eds., Volcanism of the eastern Snake River Plain, Idaho, a Comparative Planetary Geology Guidebook: Office of Planetary Geology, N.A.S.A., washington, D.C., p. 23-44.

Griggs, A.B., 1976, The Columbia River Basalt Group in the Spokane quadrangle, Washington, Idaho, and Montana: U.S. Geol. Survey Bull. 1413, $39 \mathrm{p}$.

Helz, R.T., 1978, The petrogenesis of the Ice Harbor Member, Columbia Plateau, Washington - A chemical and experimental study: Penn. State Univ., Univer sity Park, Ph.D. Jissert., 284 p.

Helz, R. T., Wright, T.J., and Swanson, D.A., 1976 , petrogenetic aignificance of chemical trends in the youngest unit of Yakıma Basalt on the Columbia Plateau, northwest U.S.A.: 0. Gonzales Perran, ed. 
Inter. Assoc. Volcanol. Chem. Earth's Interior, Symposium on Andean and Antarctic Volcanology, Proc., p $465-481$.

Hogenson, G.M., 1964, Geology and ground water of the Unatilla River basin, Oregon: U.S. Geol. Survey Water-Supply Paper $1620,162 \mathrm{p}$.

Holden, G. S., and Hooper, P.R., 1976, Petrology and chemistry of a Columbia River basalt section, Rocky Canyon, west-central Idaho: Geol. Soc. America Bull., v. 87 , p. 215-225.

Hooper, P.R., 1974, Petrology and chemistry of the Rock Creek flow, Columbia River Basalt, Idaho: Geol. Sœ. America Bull., v. 85, p. 15-26. Hoyt, C.L., 1961, The Hamunond sill - an intrusion in the Yakima Basalt near Wenatchee, Washington: Nor thwest Science, v. 35, p. 58-64.

Jackson, D.B., 1975, Description of the geolectric section, Rattlesnake Hills unit 1 well, Washington: Jour. Research U.S. Geol. Survey, v. 3, p. 665-669. Jaeger, J.C., 1961, The cooling of irregularly shaped igneous bodies: Am. Jour. Sci., v. 259, p. 721-734. Jones, J.G., 1968, Pillow lava and pahoehoe: Jour. Geology, v. 76 , p. 485-488.

Rleck, W.D., 1976, Chemistry, petrography, and stratigraphy of the Columbia River Group in the Imnaha River Valley region, eastern Oregon and western Idaho: Washington State Univ, , Pullman, Ph.D. Dissert., 203 p.

Lefebvre, R.H., 1970, Columbia River basalts of the Grand Coulee area, in Gilmour, E.E., and stradling, Dale, eds., proc. Second Columbia River Basalt Symposium: Cheney, Eastern Wash. State College Press, p. 1-38.

Lindsley, D.F., Smith, Douglas, and Haggerty, S.E., 1971, petrography and mineral chemistry of a differentiated flow of Picture Gorge Basalt near Spray, Oregon: Carnegie Institute of Washington, Yearbook 69, p. 264-285.

Long, P.E., 1978, Characterization and recognition of intraflow structures, Grande Ronde Basalt: Rockwell Hanford Operations Informal Report RHO-BWI-LD-10, $74 \mathrm{p}$.

Mackin, J.H., 1961, A stratigraphic section in the Yakima Basalt and the Ellensburg Formation in southcentral Washington: Washington Div. Mines and Geology Report Inv. 19, $45 \mathrm{p}$

McDougall, Ian, 1976, Geochemistry and origin of basalt of the Columbia River Group, Oregon and Washington: Geol. Soc. America Bull., v. 87, p. $777-792$.

McRee, E.H., Swanson, D.A., and Wright, T.L., 1977, Duration and volume of Columbia River Basalt volcanism, Washington, Oregon, and Idaho: Geol. Soc. America Abstracts with Programs, v. 9, no. 4, p. $463-464$.

Moore, J.G., 1975, Mechaniss of formation of pillow lava: Am. Scientist, v. 63, D. 269-277.

Moote, ป. G., Phillips, R.L., Grigg, R.W., Peterson, D.h., and Swanson, D.A., 2973, Flow of lava into the seâ, 1969-1971, Kilauea Voicano, Hawail: Geol. Soc. America Bull, v. 84, p. 537-546.

Myers, C. W., and Price, S.M., 1979, Compilation geologic map of the Pasco Basin, south-central washington: Rockwell Hanforc operations, RHO-BWI-ST-4, scale $1: 62,500$.

Nathar, Simon, and Fruchter, J.S., 1974, Geochemical and paleomagnetic stratigraphy of the Picture Gorge and Yakima Basalts (Columbia River Group) in central Oregon: Geol. Soc. America Buil., v. 85, p 63-76.

Nelson, D.O., Swanson, D.A., and Wright, T.L., 1976, Strontium isotopic composition of intracanyon flows of Yakima Basalt, southeast Wasnington: Geol. Soc. Amesca Abstracts with Programs, v. 8, no. 3 , 1. 399.
Newman, K.R., 1970, Palynology of interflow sediments from the Standard Oil Company of California RattleSnake Hills no. 1 well, Benton County, Washington, in Gilmour, E.H., and Stradling, Dale, eds., Proc. Second Columbia River Basalt Symposium: Cheney, East. Wash. State College Press, p. 201-207.

Osawa, M., and Goles, G.G., 1970, Trace-element abundances in Columbia River basalts, in Gilmour, E.H., and Stradling, Dale, eds., Proc. Second Columbia River Basalt Symposium: Cheney, East. Wash. State College Press, p 173-175.

price, S.M., 1977, An evaluation of dike-flow correlations indicated by geochemistry, Chief Joseph Swarm, Columbia River basalt: Idaho Univ., Moscow, Ph.D. Dissert., 320 p.

Raymond, J.R., and Tillson, D.D., 1968, Evaluation of a thick basalt sequence in south-central washington: Atomic Energy Commis. Research and Development Rept. BNWL-776, $126 \mathrm{p}$.

Reidel, S.P., 1978, The stratigraphy and petrogenesis of the Grande Ronde Basalt in the lower Salmon and adjacent Snake River canyons: Wash. State Univ., Pullman, Ph.D. thesis, 415 p.

Ross, M.E., 1978, Stratigraphy, structure, and petrology of Columbia River basalt in a portion of the Grande Ronde-Blue Mountains area of Oregon and Washington: Idaho Univ., Moscow, Ph.D. Dissert., $413 \mathrm{p}$.

Ryan, M.P., and Sammis, C.G., 1978, Cyclic fracture mechanisms in cooling basalt: Geol. Soc. America Bull., v. 89, p. 1295-1308.

Schmincke, H.-U., 1967a, Flow directions in Columbia River basalt flows and paleocurrents of interbedded sedimentary rocks, south-central Washington: Geol. Rundschau, v. 56, p. 992-1020.

$1967 \mathrm{~b}$, Stratigraphy and petrography of four upper Yakima Basalt flows in south-central Washington: Geol. Soc. America Bull., v. 78, p. 1385-1422.

1967c, Fused tuff and peperites in south-central Washington: Geol. Soc. America Bull., v. 78, p. 319-330.

Shaw, H.R., and Swanson, D.A., 1970, Eruption and flow rates of flood basalts, in Gilmour, E.H., and Stradling, Dale, eds., Proc. Second Columbia River Basalt Symposium: Cheney, Eastern. Wash. State College Press, p. 271-299.

Snavely, P.D., Jr., MacLeod, N.E., and Wagner, H.C., 1973, Miocene tholeitic basalts of coastal Oregon and washington and their relations to coeval basalts of the Columbia Plateau: Geol. Soc. America Bull., v. 84, p. 387-424.

Spry, A., 1962, The origin of columnar jointing, particularly in basalt flows: Geol. Soc. Australia Jour., v. 8, p. 191-216.

Swanson, D.A., 1972, Magma supply rate at Kilauea Volcano, 1952-1971: Science, v. 175, p. 169-170.

1973, Pahoehoe flows from the 1969-1971 Mauna Ulu eruption, Kilauea Volcano, Hawaii: Geol. Soc. America Bull., v. 83, p. 615-626.

Swanson, D.A., and Wright, T.L., 1976a, Guide to field trip between Pasco and Pullman, Washington, emphasizing stratigraphy, vent areas, and intracanyon flows of Yakima Basalt: Geol. Soc. America Cordilleran Sect. Mtg., Pullman, Washington, Field Guide no. 1, 33 p.

$1976 \mathrm{~b}$, Magnetostratigraphic units in the Yakima Basalt, southeast Washington: Geol. Soc. America Abstracts with Programs, v. 8, no. 3, p. 413-414.

1978 , Bedrock geology of the northern Columbia Plateau and adjacent areas, in The Channeled Scabland, Baker, V.R., and Nummedal, Dag, eds.:

N.A.S.A. Office Space Sci., Planetary Geol. Program, Washington, D.C., p. 37-57.

1979, Source areas and distribution of major units in the Columbia River Basalt Group: Geol. 
Soc. America Abstracts with Programs, v, 11, no. 3, p. 131 .

Swanson, D.A., Wright, T.L., and Helz, R.T., 1975, Linear vent systems and estimated rates of magma production and eruption for the Yakima Basalt on the Columbia Plateau: Am. Jour. Sci., v. 275, p. 877905.

Swanson, D.A., Wright, T.L., Camp, V.E., Gardner, J.N., Helz, R.T., Price, S.A., and Ross, M.E., 1977 , Reconnaissance geologic map of the Columbia River Basalt Group, Pullman and Walla Walla quadrangles, washington and adjacent Idaho: U.S. Geol. Survey Open-file Rept. 77-100, scale 1:250,000.

Swanson, D.A., Anderson, J.L., Bentley, R.D., Byerly, G.R., Camp, V.E., Gardner, J.N., and Wright, T.L., 1979a, Reconnaissance geologic map of the Columbia River Basalt Group in eastern Washington and northern Idaho: U.S. Geol. Survey Open-file Rept. 79-1363, scale 1:250,000.

Swanson, D.A., Wright, T.L., Hooper, P.R., and Bentley, R.D., 1979b, Revisions in stratigraphic nomenclature of the Columbia River Basalt Group: U.S. Geol. Survey Bu1l. 1457-G, 59 p.

Swanson, D.A., Wright, T.L., and zietz, Isidore, 1979c, Aeromagnetic map and geologic interpretation of the west-central Columbia Plateau, washington and Oregon: U.S. Geol. Survey Geophys. Invest. Map. G.P. 917, scale 1:250,000.

Swanson, D.A., Wright, T.L., Camp, V.E., Gardner, J.N., Helz, R.T., Price, S.M., Reidel, S.P., and Ross, M.E., 1980, Reconnaissance geologic map of the Columbia River Basalt Group, Pullman and Walla Walla quadrangles, southeast Washington and adjacent Idaho: U.S. Geol. Survey Misc. Geol. Invest. Map. I-1139, scale 1:250,000, in press.

Thayer, T.P., and Brown, C.E., 1966, Local thickening of basalts and late Tertiary silicic volcanism in the Canyon City quadrangle, northeastern Oregon, in Geological Survey Research 1966: U.S. Geol. Survey Prof. Paper 550-C, p C73-C78.

Tomkeieff, S.I., 1940, The basalt lavas of the Giant's Causeway district of northern Ireland: Bull. Volcanologique, v. 6, p. 90-143.

Vallier, T.L., and Hooper, P.R., 1976, Geologic guide to Hells Canyon, Snake River: Geol. Soc. America, Cordilleran Sect. Mtg., Pullman, Wash., Field Guide no. $5,38 \mathrm{p}$.

Walker, G.W., 1973a, Reconnaissance geologic map of the Pendleton quadrangle, Oregon and Washington: U.S. Geol. Survey Misc. Geol. Invest. Map. I-727, scale $1: 250,000$.

1973b, Contrasting compositions of the youngest Columbia River basalt flows in Union and Wallowa Counties, northeastern Oregon: Geol. Soc. America Bull., v. 84, p. 425-430.

waters, A.C., 1960, Determining direction of flow in basalts: Am. Jour. Sci., v. 258-A, p. 350-366. 1961, Stratigraphic and lithologic variations in the Columbia River basalt: Am. Jour. Sci., v. 259, p. 583-611.

1962, Basalt magma types and their tectonic association--Pacific Northwest of the United States: Am. Geophys. Union, Mon. 6, p 158-170.

watkins, N.D., and Baksi, A.K., 1974, Magnetostratigraphy and oroclinal folding of the Columbia River, Steens, and Owyhee basalts in Oregon, washington, and Idaho: Am. Jour. Sci., v. 274, p. 148-189.

Wright, T.L., and Hamilton, M.S., 1978, A computerassisted graphical method for identification and correlation of igneous rock chemistries: Geology, v. $6, \mathrm{p} 16-20$.

Wright, T.L., Grolier, M.J., and Swanson, D.A., 1973, Chemical variation related to the stratigraphy of the Columbia River basalt: Geol. Soc. America Bull., v. 84, p. 371-386.
Wright, T.L., Swanson, D.A., Helz, R.T., and Byerly, G.R., 1979, Major oxide, trace element, and glass chemistry of Columbia River basalt samples collected between 1971 and 1977: U.S. Geol. Open-file Rept.
79-711. 
ROADLOG FOR GEOLOGIC FIELD TRIP BETWEEN LEWISTON, IDAHO AND KIMBERLY, OREGON

D.A. Swanson, U.S. Geological Survey, Menlo Park, CA 94025

and

T.L. Wright, U.S. Geological Survey, Reston, VA 22092

MILES

$(0.4)$

0.4

(0.95)

1.35

(0.2)

1.55

(0.2)

1.75

(1.7)

3.45

$(0.55)$

4.0

(0.95)

4.95

(1.1)

6.05

$(0.95)$

7.0

(2. 55)

9.55

(0.55)

10.1

(0.1)

10.2

(0.3)

10.5

(2.3)

12.8

Sacajawea Motor Lodge in Lewiston, Idaho (fig. 7). Drive west.

Tapadera Inn. Continue west, following signs to U.S. 12 .

Turn left to west U.S. 12 .

Cross Snake River. Enter Clarkston, Washington. The Snake here is now a lake, impounded behind the recently completed Lower Granite Dam.

Continue straight ahead on U.S. 12 toward Pomeroy and Walla Walla.

At 12:00, the Pomona Member of the Saddle Mountains Basalt fills ancient canyon of Snake River eroded into flows of the Grande Ronde Basalt $\left(R_{2}\right.$ magnetostratigraphic unit).

At 11:00, house on bluff rests on Lower Monumental Member, which was confined to an old Snake River canyon carved deeply into the older flows between about 10.5 and $6 \mathrm{~m} . \mathrm{y}$. ago.

Roadcuts in Grande Ronde Basalt for several miles.

On left, colonnade of the canyon-filling Pomona Member. Note underlying white ash, a probable correlative of which occurs near Ice Harbor Dam (stop 9).

At 1:00, steeply dipping flatirons of the Grande Ronde Basalt near core of the Gaging Station anticline.

This route passes through the Lewiston Basin, a structurally complex area recently studied by Camp (1976). Flows at or near river level along the road also occur near the top of the escarpment north of the river. A major fault follows the west-flowing river, and a faulted anticline north of the river exposes the lower three magnetostratigraphic units of the Grande Ronde Basalt as well as the upper part of the underlying Imnaha Basalt. The latest tectonism occurred in post-Lower Monumental time, as canyon-filling remnants of this $6 \mathrm{~m} . \mathrm{y}$. member have been deformed (Camp, 1976).

Quarry on left in the Pomona Member. Good example of colonnade and entablature jointing habits, generally well developed in intracanyon flows.

Look back at 4:00-5:00 and see the Gaging Station anticline in core of Lewiston Basin structure.

Bluff on left is the Lower Monumental Member. At 2:00, view down Snake River of the Grande Ronde Basalt.

Road leaves Snake River and follows Alpowa Creek.

Road crosses approximate axis of Gaging Station anticline, rapidly dying out west of the Lewiston Basin. 


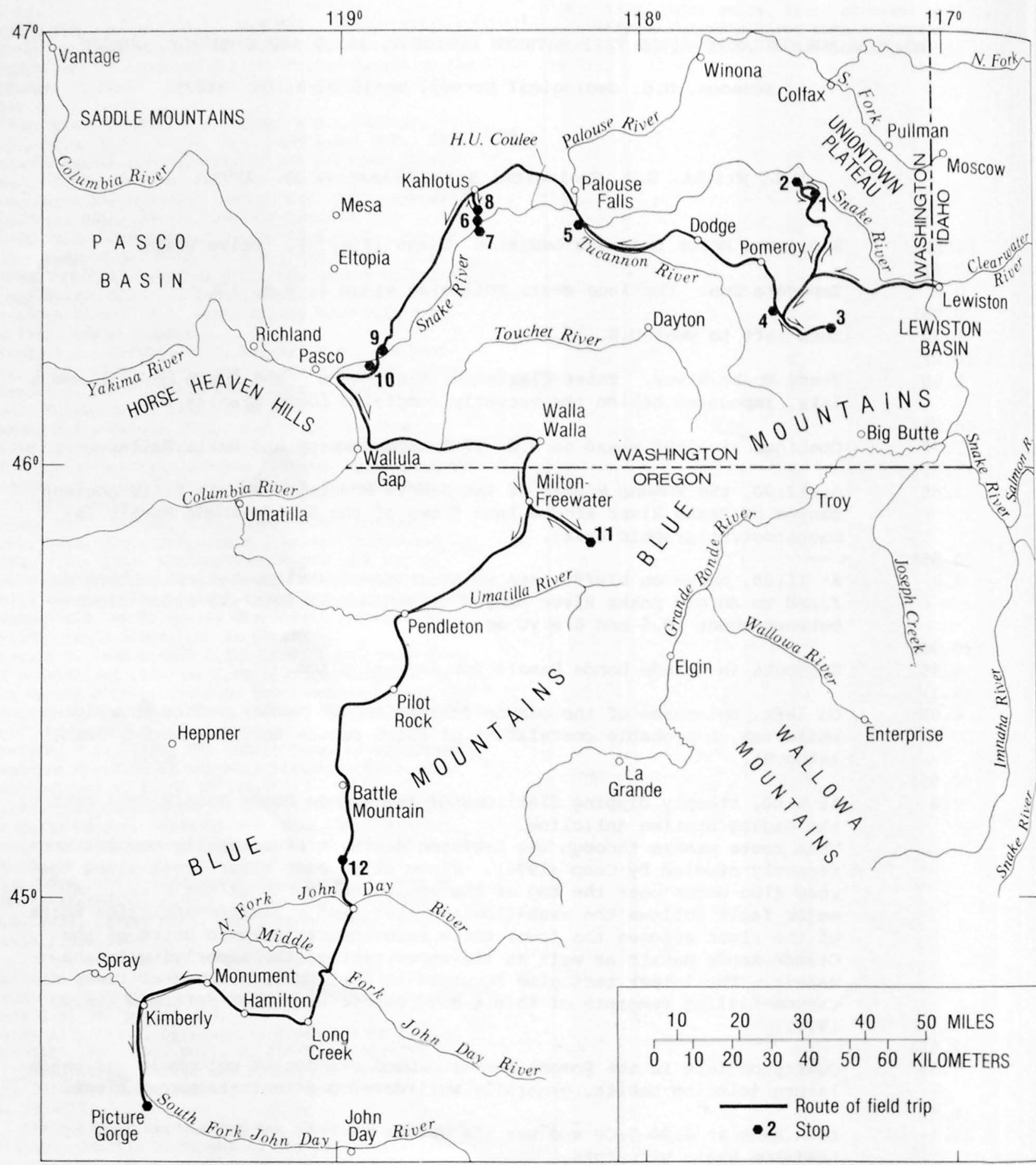

Figure 1. Map showing route of field trip, scheduled stops, and locations of important geographic features. 
(1.3)

14.1

(1.9)

16.0

(1.25)

17.25

(0.7)

17.95

(1.55)

19.5

(0.55)

20.05

(0.45)

20.5

(0.35)

20.85

(0.2)

21.05

(0.3)

21.35

(0.15)

21.5

(0.15)

21.65

(1. 25)

22.9

(0.3)

23.2

(1.5)

24.7

(0.8)

25.5

26.35

(1.55)

27.9

33.35

(4. 05)

37.4

(0.4)

37.8
Note sign on left commemorating passage of Lewis and Clark on their return trip.

Intersection with Clayton Gulch road. Continue on U.S. 12.

Intersection with Howell Grade road. From here, U.S. 12 passes upsection across the upper two magnetostratigraphic units of the Grande Ronde Basalt capped by the Roza Member of the Wanapum Basalt near Alpowa Summit. An unknown but observant geologist-polluter painted yellow letters on each flow in the section, with $\mathrm{L}$ the oldest and $\mathrm{E}$ (Roza Member) the youngest. The dip of the section is only slightly less than the gradient of the road.

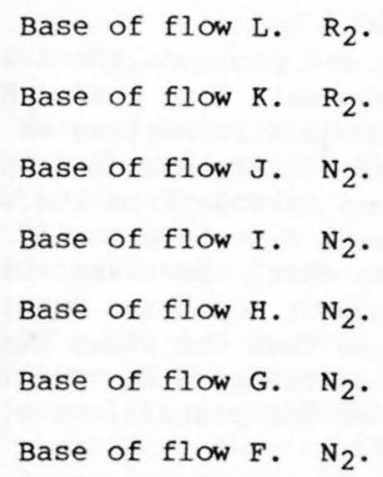

Roadcut on left shows thick ancient soil (saprolite) developed on flow F. This saprolite, marking the top of the Grande Ronde Basalt, is overlain by the Roza Member.

Flow E (Roza Member) exposed from here to summit.

Alpowa Sumit, elevation $=2785 \mathrm{ft}$.

Intersection with Ledgerwood Road. Turn right.

Small outcrop of Roza spatter on right (near-vent locality 13 in Swanson and others, 1975, table 1).

Junction with Kirby-Mayview Road. Continue straight (northward) on pavement.

Junction with Valentine Ridge Road. Continue straight. Valentine Ridge Road leads to stop 18 of Swanson and Wright (1967a), an interesting vent area for a flow in the Grande Ronde Basalt.

Roadcut just beyond junction with Connell Hill Road. Thin flows of the Roza Member, with little or no spatter. Experience shows that, in this area, such thin flows are likely to be near a vent. Continue on KirbyMayview Road.

\section{Intersection with Tramway Road. Turn right toward Tramway.}

Cliffs ahead expose a flow of Lolo chemical type in the priest Rapids Member of the Wanapum Basalt.

Stop at white stile.

STOP NO. 1. Gracefully cross stile and walk to lip of Snake River canyon for view of Grande Ronde flows and discussion of stratigraphy and mapping methods. Quarry is in a flow of Lolo chemical type in the Priest Rapids Member. 
Continue north on Tramway Road. Keep left at intersection with East Wawawai Grade road.

Junction with Kirby-Mayview Road. Turn right.

Junction with Wawawai Grade Road. Continue on pavement.

Mayview. Continue straight.

Roadcut exposing two thin flows of the Roza Member separated by welded spatter. Continue ahead.

STOP NO. 2. Bus lets passengers off here and proceeds for $1.3 \mathrm{miles,}$ turns around, and waits for passengers, who walk down road. Roadcuts show the Roza Member overlying thin, discontinuous silt resting on the sparsely plagioclase-phyric Frenchman Springs Member (2 flows). A thin saprolite and detrital(?) clay separate the Frenchman Springs from the Grande Ronde Basalt. The Frenchman Springs thickens west from here to $150 \mathrm{~m}$ in Devils Canyon (Stop 6); it does not occur farther east. Eastward thinning of the Frenchman Springs Member is typical throughout southeast Washington and northeast Oregon and is interpreted to mean that the flows pinched out against a gentle westward slope. All known feeder dikes for the Frenchman Springs Member occur in the central part of the plateau; we will see some unusual examples tomorrow.

The flows of the Grande Ronde Basalt, all in the $\mathrm{N}_{2}$ magnetostratigraphic unit, display a variety of primary structures, such as joints and rubbly tops. Many flows are thin and may have erupted locally.

One thick and two thin feeder dikes for the Roza Member are exposed. Perhaps the spatter at mileage 41.95 was erupted from this dike. This location is along the axis of the Roza vent system. One of the vent areas will be viewed at the next stop.

(5.9)

48.4

(3.35)

51.75

(4.1)

55.85

(7.9)

63.75

(0.15)

65.9

(8.4)

74.3

(2.65)

76.95

(2.3)

79.25

(2.85)

82.1

(1.1)

83.2

(2.3)

85.5

Return to U.S. 12 via Kirby-Mayview, Ledgerwood, and Ledgerwood Spur Roads.

Junction with Tramway Road. Keep right, on pavement.

Junction with North Deadman Creek road, turn right, staying on KirbyMayview Road.

Junction with Tramway Road. Continue straight.

Junction with Ledgerwood Road. Turn left, leaving pavement.

Junction with U.S. 12. Cross highway, continuing on Sweeney Gulch Road.

Junction with State Highway 128. Continue straight, up a gentle dipslope related to the Blue Mountains uplift farther south.

Road intersection. Continue straight on 128 .

Metropolis of Peola. Bear left on main road, avoiding road to Cold Springs.

Continue east on Highway 128 .

Asotin-Garfield County Line.

At 4:00, good view of dip slopes on north flank of Blue Mountains. Potter Hill ahead. 
(1.1)

86.6

(12.35)

98.95

(0.1)

99.05

(0.15)

99.2

100.45

101.35

(0.6)

101.95

(4.05)

106.0

(0.65)

106.65

(0.1)

106.75

(1.25)

108.0

(1.5)

109.5

(0.4)

109.9

(6.0)

115.9

(7.2)

123.1

STOP NO. 3. Potter Hill vent area for Roza Member. Note pumice, welded spatter, dikes, and primary dips related to cone. The Roza Member vent system is more than $165 \mathrm{~km}$ long and less than $15 \mathrm{~km}$ (probably less than 5 $\mathrm{km}$ ) wide. The vent system is defined by dikes, such as those at stop 2, and vent areas such as this one. Big Butte, visible from here to south, is another vent area from which one of the latest eruptions took place.

Turn around, and retrace route to Sweeney Gulch Road.

Junction with Sweeney Gulch Road. Bear left, staying on Highway 128 .

Roadcut exposing a Dodge flow in the Eckler Mountain Member of the Wanapum Basalt.

Base of Dodge over red saprolite developed on Grande Ronde Basalt. Roadcuts beyond expose flows in uppermost magnetostratigraphic unit $\left(\mathrm{N}_{2}\right)$ of the Grande Ronde.

Cross Pataha Creek at Columbia Center. Keep right across bridge.

STOP NO. 4. Roadcut shows the basalt of Dodge overlain by dense aphyric flows of the Frenchman Springs Member. Walk back along road $30 \mathrm{~m}$ to see saprolite under Dodge. The basalt of Dodge is in places interleaved with saprolite, showing that it was erupted during the time of regional soil formation on the Grande Ronde Basalt. Note the coarse grain size, large plagioclase phenocrysts, and grusy nature of the Dodge, which make it a fine marker in the field.

Turn right on pavement and continue down approximate dip slope on the Roza Member .

Dirt road to right. Start of Benjamin Gulch section. This section, capped by the Roza Member, exposes interbedded flows of Grande Ronde, Dodge, and dominantly Frenchman Springs chemical types, and is the only such section known in Washington. This section is of great importance, as it demonstrates that eruptions of greatly different magma chemistries overlapped in time. Presumably this locality contains flows erupted throughout the time interval during which a soil was forming elsewhere in southeast Washington.

Quarry in dense flow of the Frenchman Springs Member as at Stop 4.

The basalt of Dodge under the Frenchman Springs Member. Next few cuts reveal interlayering; exposures are good but not eyecatching. All contacts are exposed.

Approximate base of section.

Pomeroy town limit.

Intersection with U.S. 12. Turn left (west) on highway.

Junction with State Highway 126. Continue ahead on U.S. 12. For the next few miles, a ledge-forming flow is quite prominent, particularly in about 3.5 miles. This flow, informally called the Pataha flow, is of high-Mg Grande Ronde chemical type and is near the top of the Grande Ronde section in this area.

Junction with State Highway 127. Continue left (west) on U.S. 12, toward Walla Walla. Type locality of the basalt of Dodge is in roadcuts along S.H. 127, 0.95 miles northeast of junction. 
Junction with State Highway 261. Turn right toward Palouse Falls State Park. Roadcuts in next few miles expose flows in $\mathrm{N}_{2}$ part of Grande Ronde Basalt. Road follows the Tucannon River.

Junction with paved road to Little Goose Dam. Stay left, in valley. Road to dam is access to stops 10-14 of Swanson and Wright (1976a). For next mile, black cliff above road is in the Lower Monumental Member of the Saddle Mountains Basalt, which occupies a broad valley eroded through the Wanapum Basalt into the Grande Ronde Basalt at the confluence of the Snake and Tucannon Rivers. Exposures of the Pomona Member in a canyon-filling relation occur nearby.

Good exposures of tiered flow of the Grande Ronde Basalt. White ash in pockets on hillside is Mazama ash.

STOP NO. 5 (optional). Origin of tiered flows. Are tiers the result of some process completely internal to a ponded flow and related to its cooling history, or does each tier record a separate pulse of lava into a gradually deepening pond? In other words, is a tiered flow a single or multiple-flow cooling unit? Good exposures of vesicular layers defining boundaries of tiers are found above the railroad tracks to left of road.

Dark mesas to left are remnants of the Lower Monumental Member resting erosionally on the Frenchman Springs Member. Intracanyon remnants of the Pomona and Esquatzel also occur near here. The prominent bench seen above both the Palouse and Snake Rivers is along the contact of the Grande Ronde and Wanapum Basalts. Cross Snake River near mouth of Palouse River. The renowned archeologic site, Marmes Rock Shelter, is drowned beneath lake waters just up the Palouse.

Entrance to Lyons Ferry State Park. Continue straight.

Poorly exposed contact of the Grande Ronde Basalt and the Frenchman Springs Member of Wanapum Basalt.

Base of the Roza Member.

Junction with road to right to Palouse Falls state Park. Continue straight ahead. The junction is just below the contact of the priest Rapids and Roza Members. The road to the park crosses the Roza and the Frenchman Springs Members. The lip of the falls is carved into the oldest flow of the Frenchman Springs.

Flow of Lolo chemical type in the priest Rapids Member crops out just above road; it is the youngest flow throughout the area. Good example of scabland topography (Scablandia) to east (right). Begin to cross upper reaches of H.U. Coulee; roadcuts expose the Roza and Frenchman Springs Members.

View to left down H.U. Coulee, a scabland channel made famous by J. Harlan Bretz. Roadcuts beyond are the Roza and Frenchman Springs Members.

Junction with Highway 260. Turn left toward Pasco. Highway follows dry Washtucna Coulee, former course of Palouse River. Erosion caused by catastrophic flooding (the spokane floods) in the late Pleistocene diverted the river from its former course into a more direct link with the Snake River via Palouse Falls. Prior to the floods, the Palouse flowed down Washtucna Coulee to Connell and then south-southwestward to the Pasco area via Esquatzel Coulee.

The highest continuous ledge along the coulee walls between here and Kahlotus is the Roza Member; the highest discontinuous exposures are of 
the Priest Rapids Member.

(2.85)

161.5

(5.2)

166.7

$(0.7)$

167.4

(4.55)

171.95

(0.65)

172.6

(0.65)

173.25

(1.5)

174.75

View to right of gravel bar deposited by spokane floods.

Junction in Kahlotus with paved road to Pasco and Lower Monumental Dam. Turn left.

Junction with road to Lower Monumental Dam. Turn left down Devils Canyon. All roadcuts expose flows of the Frenchman Springs Member, totalling about $150 \mathrm{~m}$ thick. Contrast with the $20 \mathrm{~m}$ of the Frenchman springs seen at stop 2 .

Look ahead at remnant of the Lower Monumental Member forming cliff overlying river gravel across river beyond dam.

Large parking area to right opposite turn toward dam.

STOP NO. 6. Contact of the Frenchman Springs Member of the Wanapum Basalt and Grande Ronde Basalt. Lowest exposed flow is the Grande Ronde. It has an oxidized top and is overlain by a Frenchman Springs flow with sparse, small plagioclase phenocrysts. The oxidized zone is an incipient residual soil horizon. Traced eastward, this zone gradually thickens into a true saprolite, which is well exposed at stops 2 and 4 . As the soil zone thickens, the overlying Frenchman springs thins and finally dies out, leaving the Roza Member resting directly on saprolite. This is evidence that the Frenchman Springs flows were erupted in a basin, presumably created by earlier subsidence or westward tilting of the Columbia plateau. STOP NO. 7. (Optional) From stop 6, drive across Lower Monumental Dam and park along road 1 mile beyond southeast end of dam, at base of the flow defining the Lower Monumental Member. This flow, at $6 \mathrm{~m} . \mathrm{y}$. the youngest flow in the Columbia River Basalt Group, extends at least as far east as Asotin, Washington. The Lower Monumental has not been recognized farther west than its type locality. The flow overlies river gravel consisting of basalt, metavolcanic rocks, and a very few plutonic rocks with lenses of quartz-feldspar-muscovite sand. This assemblage is clearly that of an ancestral Snake River, not a small stream heading on the plateau itself.

Retrace route from stop 6. Looking up Devils Canyon from this point, a good cross-sectional view of flows filling a steep-walled gorge is exposed on the northeast wall of the canyon.

Park in small turnout on right.

STOP NO. 8. Intracanyon flows. Before Lower Monumental time, the ancestral Snake River apparently occupied a gorge $2-3 \mathrm{~km}$ north of the present canyon. Four different lava flows poured down this gorge, with renewed canyon cutting between each eruption, resulting in the compound lava fill. exposed in cross section in the cliffs on either side of the road. East of the road, a "triple junction" is well exposed. Here the 12 m.y. Pomona Member ( $r$ ight) filled an almost vertically walled gorge cut into the oldest known intracanyon flow in this area, about $12.5 \mathrm{~m} . \mathrm{y}$. (left). Note the nearly horizontal columnar jointing in the Pomona along the contact. After a period of erosion, which beveled the Pomona and older intracanyon flow, the $10.5 \mathrm{~m} \mathrm{y}$. Elephant Mountain Member was erupted. It forms the uppermost flow in contact with both of these older intracanyon flows. West of the road, relations are more involved. Four flows are present here, and they meet at a common point above the railroad grade. The same three flows in the cliff east of the road are also here, with a fourth, the Esquatzel Member, between the unnamed intracanyon flow and the Pomona. Eastward from a point $8 \mathrm{~km}$ east of Devils Canyon, the pre-Lower Monumental canyon of the Snake follows the present canyon rather closely. West of there, however, the older canyon continued due west, meeting Esquatzel Coulee between Mesa and Connell. The course of this old canyon can be traced using detailed aeromagnetic data (Swanson and others, 
1979c), as the thick intracanyon flows of uniform polarity exhibit narrow, sinuous anomalies of greater amplitude than the thin, normal and reversed flows forming the wallrock. We can speculate that the Elephant Mountain flow so thoroughly choked the canyon that the Snake spilled southward over a divide, located about $8 \mathrm{~km}$ east of Devils Canyon near Magallon ranch, into a tributary of the ancestral Columbia River leading southwest toward Pasco. Erosion of this divide proceeded comparatively rapidly, and the Snake has remained in this canyon since then.

$(3.05)$

177.8

(9.3)

187.1

(0.75)

187.85

197.25

(0.65)

197.9

(10.65)

208.55

(5.05)

213.6

(2.75)

216.35

(0.3)

216.65

$(0.4)$

217.05

(0.2)

217.25
Continue up Devils Canyon. Turn left at intersection, toward Pasco. Roadcuts in the Roza Member. Contact with the priest Rapids exposed in highest cut.

Continue straight at junction with Wallace Walker road.

Outcrop of the Priest Rapids Member below the Elephant Mountain Member in gully to right.

Continue straight at intersection with Burr Canyon road. A feeder dike for a flow of the Frenchman Springs Member can be reached by following the Burr Canyon road to the lowest railroad right-of-way shown on the Lower Monumental Dam 7-1/2' quadrangle. The tracks have been removed from this right-of-way, and the route was drivable with care in 1977 . From Burr Canyon, follow the abandoned railroad about $2.5 \mathrm{miles}$ to near Abe triangulation station (Elwood 7-1/2' quad). Several small faults offset the red, oxidized contact of the Grande Ronde Basalt and Frenchman Springs Member exposed along the way. The widest plagioclase-phyric dike, evident in cuts, projects across the river and feeds the prominent flow exposed at top of dike. By climbing up hill (poor exposure) above Abe, the top of the dike can be seen in cuts along the relocated railroad. A shallow pool of columnar basalt fills the flared top of dike and merges laterally into an extensive porphyritic flow.

Ghostly sand dunes to right.

Leave loess hills and enter onto dip slope developed in the Elephant Mountain Member. Spokane floods stripped away the loess.

Junction with road to Ice Harbor Dam. Turn left (south).

Turn left, onto another paved road, just before dam. Sign points to Boat Landing.

Junction with gravel road. Keep left on gravel road across wooden plank bridge.

Junction of track roads. Both lead to same place. Righthand route was best in 1979 .

End of road. Bus may need to park before end.

STOP NO. 9. Examine railroad cuts 500-1200 m upriver from end of road. Flows of the Pomona and Elephant Mountain Members are well exposed at railroad level. The basalt of Martindale in the Ice Harbor Member overlies the Elephant Mountain Member above the railroad. Examine invasive contact relation of the Pomona and a white vitric tuff $1200 \mathrm{~m}$ from end of road. Three dikes of Basin City chemical type (Helz and others, 1976) intrude the Elephant Mountain at locality 7 of Swanson and others (1975, table 2). The dikes are difficult to spot. The nomally magnetized dikes occur along a positive linear aeromagnetic anomaly that extends $30 \mathrm{~km}$ south of the Snake River and $50 \mathrm{~km}$ north of the river (Swanson and others, 1979c). They form part of a linear vent system for the $8.5 \mathrm{~m} . \mathrm{y}$. Ice Harbor Member described by Swanson and others (1975). 
(0.85)

218.1

(1.05)

219.15

(0.15)

219.3

(1.1)

220.4

(1.1)

221.5

(0.2)

221. 7

(1.3)

223.0

(0.95)

223.95

(5.3)

229.25

(4.3)

232.55

(4.6)

238.15

(2. 75)

240.9

(0.75)

241.65

(1.7)

243. 35

(1. 25)

244.6

Retrace route to intersection with road across dam.

Turn left and drive across dam. Keep right on pavement at south end of dam.

Turn right toward river at T-intersection.

Bear left onto gravel road. Follow road toward west. Bluffs on left expose the basalt of Martindale overlying the Elephant Mountain Member.

Park.

STOP NO. 10. The craggy bluff near the parking area is the remnant of a tuff cone built over a vent for the basalt of Martindale in the Ice Harbor Member (locality 16 of Swanson and others, 1975, table 2). Note the poorly bedded nature of the cone, the palagonitic alteration of most of the glassy tephra, and the angular unconformity visible on the northwest face. A Martindale flow overlies the cone. Walk $600 \mathrm{~m}$ downriver along trail to cuts exposing the Elephant Mountain Member and the basalts of Martindale and Goose Island (locality 12 of Swanson and others, 1975, table 2). The flows occupy a shallow northwest-trending syncline, also recognizable across the river. Note the plagioclase-clinopyroxene clots in the columnar Martindale flow. A dike of Goose Island chemical type cuts the Martindale flow. Breccia interpreted as drainback rubble occurs in upper part of dike; the rubble merges into thin vesicular flows, overlain by a thicker flow of Goose Island type. At this locality, the upper Goose Island flow and the columnar Martindale flow have both been dated by $\mathrm{E}$. H. McKee, using whole rock $\mathrm{K}-\mathrm{Ar}$ methods, at $8.6 \pm 0.3 \mathrm{~m} . \mathrm{y}$. Refer to Helz (1978) for more information on the Ice Harbor Member.

Retrace route back to paved road. Continue straight ahead (south).

Martindale tephra in roadcuts.

Horse Heaven anticlinal uplift straight ahead in distance.

Junction with road to Pasco. Turn right. Continue through Burbank.

Junction with U.S. 395. Turn left (south).

At 1:00, entrance to Wallula Gap, a water gap across the Horse Heaven uplift through which the Columbia River flows.

Boise Cascade plant. Hold your nose.

To right across Columbia River is a series of faulted, doubly plunging anticlines exposing the Frenchman Springs Member and younger flows.

Junction with U.S. 12. Turn left, toward Walla Walla. Side trip to right for 4.2 miles into Wallula Gap shows excellent exposures of the thick Frenchman Springs Member overlain by the Umatilla Member of Saddle Mountains Basalt; the Roza and Priest Rapids Members are missing. A Martindale flow caps highest visible point west of river; it overlies imbricated Snake River gravel, compositionally similar to that at stop 7, showing that an ancestral Wallula Gap existed at least $8.5 \mathrm{~m} \cdot \mathrm{y} \cdot \mathrm{b} \cdot \mathrm{p}$.

Faceted ridge spurs to right reflect relatively young faulting along Horse Heaven front.

Roadrut on right shows white Mt. St. Helens "S" tephra layer in silts of the Touchet beds. The tephra is about 12,000 years old and helps to date some of the youngest spokane flooding, which produced the Touchet beds. 
(1.9)

248.75

(1.4)

250.15

252.45

(1.3)

253.75

(16.15)

269.9

(0.7)

270.6

(0.3)

270.9

0

(4.75)

4.75

(0.75)

5.5

(0.15)

5.65

(0.15)

5.8

(1.2)

7.0

(1. 45)

8.45

(0.2)

8.65

(1. 55)

10.2

(0.45)

10.65

(0.85)

11.5

Roadcuts in the Frenchman springs Member.

Flow of Martindale type in the Ice Harbor Member forms low mesa ahead.

View left across Walla Walla River shows the thick Umatilla Member overlain by the basalt of Martindale and underlain by the Frenchman Springs Member. A small sheeted dike complex, consisting of 5 dikes of Goose Island (Ice Harbor Member) chemical type, cuts the Umatilla but is not evident from highway.

Roadcuts for next mile in the Frenchman Springs Member.

Approximate crest of north-south anticline forming west boundary of Walla Walla Basin.

Easternmost basalt exposure (Frenchman Springs Member) in western part of Walla Walla basin.

Bluffs to right are type locality of Touchet beds. From here to Walla Walla, roadcuts reveal Touchet beds and loess.

Leave U.S. 12, turning right on road to Pendleton, Oregon.

Continue straight at junction with Highway 125 .

Turn right on Highway 125. Stay on 125 through Walla Walla toward MiltonFreewater, Oregon. This route bypasses most motels. Trip log is resumed about 5.5 miles from downtown Walla Walla, at Oregon-Washington State line. Here, Washington Highway 125 becomes Oregon Highway 11. SECOND DAY

Oregon-Washington border between Walla Walla, Wash. and Milton-Freewater, Oregon.

From left lane in Milton Freewater, turn left toward Pendleton on Highway 11.

Turn left off Highway 11 at bottom of hill, just beyond clifton Motel, toward upper Walla Walla River. Cross railroad tracks, keeping right.

Follow pavement to left on SE 15th Ave.

The Frenchman Springs Member is exposed on hillside ahead.

Keep left at intersection.

Approximate base of the Frenchman Springs in roadcut on left.

Bridge across Walla Walla River. Road enters the Blue Mountains, an uplifted and faulted region extending from central Oregon to extreme southeast Washington. Route goes progressively downsection, as dips are about 2-3 degrees toward the Walla Walla basin.

Bridge across South Fork Walla Walla River.

Turn right toward South Fork.

Roadcut on left exposes $10 \mathrm{~m}$-wide, vertical feeder dike of the Frenchman Springs Member. Note nearby horizontal columns. Dike cuts vesicular flow top in $\mathrm{N}_{2}$ unit of the Grande Ronde Basalt.

Route follows the straight canyon of the South Fork of the Walla Walla River, which forms a segment of the Olympic-Wallowa lineament, a straight 
topographic feature reaching about $700 \mathrm{~km}$ from the northwest tip of washington to the Wallowa Mountains in northeast Oregon. Origin of the lineament is subject of much debate. Evidence to be seen at stop 11 shows that this segment of the lineament has been structurally inactive for the last 14-15 m.y.

(2.4)

13.9

(1.4)

15.3

(2.3)

17.6

(0.55)

18.15

(0.4)

18.55

(0.4)

18.95

(13.4)

32.35

(0.95)

33.3

(2.1)

35.4

(0.5)

35.9

(0.55)

36.45

(1. 5$)$

37.95

(0.2)

57.65

(0.4)

58.05

(0.4)

58.45

(1.05)

59.5

(0.2)

59.7

(0.25)

59.95

(0.15)
Approximate location of contact between $R_{2}$ and $N_{2}$ units of the Grande Ronde Basalt.

Good exposure of rubbly top on a flow in the $R_{2}$ unit of the Grande Ronde.

Exposure on left of gently dipping feeder dike of the Frenchman Springs Member.

Cross river. Enter Harris Park. Continue straight.

Bus parking.

End of road.

STOP NO. 11. Observe the $60 \mathrm{~m}$-thick, gently dipping (15-20 degrees) dike of the Frenchman Springs Member on both sides of river. Note that it crosses canyon, which defines the olympic-Wallowa lineament in this area, with no obvious offset. $\mathrm{K}-\mathrm{Ar}$ date on dike by Ted McKee is about 14.5 m.y. Walk across footbridge, turn left on trail, dodge low-hanging branches, and walk to lower contact of columnar dike. Observe glassy selvedge. Continue on higher of two trails to upper glassy selvedge. Discuss criteria for distinguishing a flow from such a dike. What are conditions under which such gently dipping dikes are formed?

Retrace route to Highway 11 in Milton-Freewater. Turn left on Highway 1 toward Pendleton.

Good view to left of Blue Mountains front.

Roadcut in the Umatilla Member.

Start of series of roadcuts in the Frenchman Springs Member.

Fault breccia in the Frenchman Springs Member. Rock throughout roadcut is shattered. Undated colluvium is offset by small fault at far end of cut. The breccia occurs along north-trending faults.

Junction of road to Tollgate and Elgin across Blue Mountains. Continue toward Pendleton, more or less along axis of the Agency syncline, with poorly exposed flows of the Frenchman Springs Member in places.

Narrow bridge across Umatilla River in Pendleton. Beyond bridge, keep right toward Portland.

Junction with U.S. 30 .

Original Pendleton woolen mill to right.

Continue straight ahead through town.

Get in left lane opposite Pendleton Round-Up grounds.

Stop sign. Continue on U.S. 395 across railroad tracks. Follow sign to Pilot Rock.

Turn left at blinking stop light. 
60.1

(0.1)

60.2

(2. 45)

63.6

(0.95)

64.55

(0.75)

65.3

(5. 5)

70.8

(2. 55)

73.35

(0.6)

73.95

(0.3)

74.25

(0.2)

74.45

(7.7)

82.15

(4. 55)

36.7

(7.3)

94.0

(1.5)

95.5

(0.2)

95.7

(1. 65)

97.35

(0.25)

97.6

(0.5)

98.1

(0.4)

98.5

(1. 25)

99.75

(5.9)

105.65

(2.85)

108.5

Turn right at stop sign. Dead ahead is cut showing the Frenchman Springs Member overlying thick saprolite on the Grande Ronde Basalt.

Continue on U.S. 395 toward Pilot Rock and John Day. Do not enter freeway.

On left, earth-fill McKay Reservoir Dam, in danger of collapsing until refurbished in 1978. Rounded hills on both sides of road are eroded in the McKay beds of Hogenson (1964), a Pliocene fanglomerate.

Roadcut in the McKay beds. Many more such cuts between here and pilot Rock.

Good view of Blue Mountains front to left and ahead. The Frenchman Springs Member caps highest ridges to left but is absent ahead.

Across valley to right, saprolite separating the Grande Ronde Basalt and the Frenchman Springs Member exposed in railroad cuts.

Town of Pilot Rock. Bluff at 1:00 is the Pilot Rock, mostly the Grande Ronde Basalt but relay station rests on basal flow of the Frenchman Springs Member.

Continue left on U.S. 395.

Continue right on U.S. 395.

Good view of unimposing pilot Rock. Roadcuts for long distance are in $\mathrm{N}_{2}$ unit of the Grande Ronde Basalt. The Frenchman Springs does not occur south of this area.

Junction with Highway 74. Keep left on U.S. 395. By fall of 1979, mapping of the basalt had not been finished beyond this point, so the following $\log$ is necessarily skimpier than it has been. Some information is taken from Walker (1973a) and Brown and Thayer (1966).

Good views of Blue Mountains front.

Dip slopes to right of road give clear sense of uplift.

Roadcut on left exposes fault in the Grande Ronde Basalt.

The Grande Ronde Basalt rests on soil developed on quartz diorite of Jurassic or Cretaceous age.

Entrance to Battle Mountain State Park.

Low-Mg flows of the Grande Ronde Basalt in roadcut on left (Nathan and Fruchter, 1974).

Coarsely columnar, probably valley-filling flow of the Grande Ronde Basalt over granitoid in roadcut on left.

Blue Mountains crest, $4270 \mathrm{ft}$. Structural crest $1-2 \mathrm{~km}$ south of here.

Contact of the Grande Ronde Basalt and the John Day Formation poorly exposed.

Terraces at 10:00 are developed in Pliocene sediments, trapped in structurally controlled basin (Walker, 1973a).

Junction with Highway 344. Continue straight on U.S. 395. Ridge ahead in the Grande Ronde Basalt. 
(0.85)

109.35

(0.2)

109.55

(0.95)

110.5

(0.3)

110.8

(0.35)

111. 15

(8.9)

120.05

(1.6)

121.65

(1. 3)

122.95

(1. 05)

124.0

(6. 95)

130.95

(0.45)

131.4

(0.3)

131.7

(0.8)

132.5

.$(0.5)$

133.0

(0.5)

133.5

(0.1)

133.6

(1. 05)

134.65

(1.1)

135.75

(0.85)

136.6

(1.1)

137.7

(3.05)

140.75

(6. 35)

147.1

(8.35)

155.45

(0.3)

155.75

(0.55)

156.3

Start of Camas Creek section through the Grande Ronde and Picture Gorge Basalts.

Pillowed flow of the Grande Ronde Basalt in roadcut.

Interbed between flows of the Grande Ronde Basalt in roadcut on right.

Complexly jointed and faulted flows of the Grande Ronde. Some horizontal slickensides.

STOP NO. 12. Roadcut near mile post 52 exposing contact of the Grande Ronde and Picture Gorge Basalts. Discovered and described by Nathan and Fruchter (1974). Aphyic, normally magnetized flow of the Grande Ronde (probably $\mathrm{N}_{l}$ but not known certainly) overlies thin organic-rich interbed resting on highly plagioclase-phyric, magnetically normal flow of the Picture Gorge. Chemistry by Nathan and Fruchter (1974) confirms stratigraphic assignments.

Bridge at mouth of Camas Creek. North Fork of John Day River to right.

Cross 45 th parallel.

Bridge over North Fork of John Day River.

Dale. All roadcuts are in the picture Gorge Basalt.

Meadow Pass, $4127 \mathrm{ft}$.

The Picture Gorge Basalt over the John Day Formation in roadcuts on right.

Cretaceous diorite on left.

Slopes to right are foliated diorite.

Cross Middle Fork of John Day River.

Hyaloclastite in the picture Gorge Basalt in roadcut on left. Flow probably fills valley eroded into Paleozoic rocks.

Paleozoic metasedimentary rocks for next 0.9 miles.

At 3:00, scenic view of the picture Gorge Basalt forming mesa.

The Picture Gorge Basalt in roadcut on left.

View straight ahead of the Picture Gorge Basalt dipping southeast from Blue Mountains uplift.

Sumit of Ritter Butte, $3991 \mathrm{ft}$.

View ahead of Long Creek Mountain, underlain by the faulted Picture Gorge Basalt.

Town of Long Creek. Turn right off U.S. 395 toward Monument and Kimberly. Roadcut on right exposes contact of the Picture Gorge Basalt and John Day Formation.

Geologic marker on left, courtesy of T.P. Thayer, explains history of area. Scenic view down valley of the picture Gorge Basalt over red tuffaceous 
(0.5)

156.8

(1. 7$)$

158.5

(0.65)

159.15

(0.5)

159.65

(0.6)

160.25

(0.35)

160.6

(1.25)

161.85

(1.8)

163.65

167.55

(0.75)

168.3

(0.75)

169.05

(10.35)

179.4

(3.15)

182.55

rocks of the John Day Formation.

Approximate contact of the Picture Gorge and the John Day in roadcuts on right.

Hamilton.

Tuffaceous rocks of the John Day Formation, here chiefly bioturbated airfall tuff.

Landslides in the John Day Formation. Altered tuffs slide easily, especially when wet and overlain by basalt.

Geologic marker describes Sunken Mountain landslide to left. This and other markers in the area were conceived and written by Tom Thayer, who worked for many years on the Canyon City 2 degree sheet.

Thick section of the picture Gorge Basalt ahead.

Views ahead and to right of angular unconformity between the Picture Gorge Basalt and John Day Formation.

To right, dike and irregular intrusive body of the Picture Gorge Basalt in the John Day Formation. The Picture Gorge was erupted wholly within this region. Its feeder dikes comprise the Monument dike swarm. Fruchter and Baldwin (1975) found good chemical matches between flows and dikes of the Picture Gorge, substantiating the notion that the two are indeed related. From here to Kimberly itself we will see many of these dikes; only a few are pointed out in the log.

Dead ahead is Monument Mountain, one of the thickest exposed sections of the Picture Gorge Basalt.

Cross the North Fork of John Day River and enter town of Monument. View to left of Picture Gorge intrusive bodies in the John Day Formation.

Roadcut across thick dike. For next 10 miles, dikes are very common, cutting flows of the Picture Gorge as well as the older John Day Formation.

Zeolites in pegmatoidal flow of the picture Gorge Basalt in roadcut on right.

General store in Kimberly. Start of geologic field trip summarized by P.T. Robinson (this volume). 
GUIDE TO GEOLOGIC FIELD TRIP BETWEEN KIMBERLY AND BEND, OREGON WITH EMPHASIS ON THE JOHN DAY FORMATION

Paul T. Robinson, Department of Earth Sciences, University of California, Riverside, California 92521 and

Gerald F. Brem, Department of Earth Sciences, California State University, Fullerton, California 92634

\section{INTRODUCTION}

The John Day Formation of north-central Oregon is a widespread, largely pyroclastic unit lying beween the Eocene Clarno Formation and the Miocene Columbia River Basalt (Figure 1). The bulk of the unit consists of andesitic to dacitic tuffaceous claystone and air-fall tuff derived from vents west of the present-day outcrops. The age of the formation based on vertebrate fossils and $\mathrm{K}$-Ar dating ranges from approximately 36 to $18 \mathrm{~m} \cdot \mathrm{y}$. B. P. Woodburne and Robinson, 1977). Hence, the formation is believed to provide a well exposed depositonal record of middle Tertiary Cascade volcanism not avallable elsewhere.

Detalled studies of the formation have been carried out by a number of workers in the last 20 years. Studies in the vicinity of the type area, near Picture Gorge, have been carried out by Fisher (1966a, 1966b, 1967, and 1968), Fisher and Rensberger (1972), Fisher and Wilcox, (1960) and Hay $(1962 a, 1962 b, 1963)$. Outcrops in and west of the Blue Mountains have been studied by Peck (1964), Robinson (1975), Robinson and Stensland (1979), Swanson and Robinson (1968), and Woodhurne and Robinson (1977). Reconnaissance geologic maps have been completed for most of the unit (Swanson, 1969; Robinson, 1975). Detailed chemical and mineralogical studies of the ash-flow and air-fall tuffs are in progress by the authors.

\section{STRATIGRAPHY}

\section{General Aspects}

The John Day Formation crops out widely over north-central Oregon, occurring in three geographically separate areas (Figure 1). The type locality (eastern facies) lies east of the Blue Mountain uplift and includes the Picture Gorge district and the Mitchell area. Similar rocks cropping out south of the Ochoco Mountains constitute a southern facies, and a western facies is exposed in the area between the Blue Mountains and the Cascade Range. Although rocks from these three areas are lithologically similar, consisting chiefly of tuffaceous claystone and air-fall tuff, certain systematic differences exist reflecting the presence of topographic barriers between the areas during depositon. Specifically, the western facies contains numerous intercalated ash-flow tuffs and lava flows which are rare or absent in the eastern and southern facies.

Considerable disagreement exists as to the nature and stratigraphic position of the boundary between the John Day and Clarno Formations. In areas east of the Blue Mountains the top of the Clarno Formation is generally marked by a well developed red saprolite. Local incorporation of this material into the lower part of the John Day Formation accounts in part for the red color of the lower member (Big Basin member of Fisher and Rensberger, 1972). Waters (1954) recognized a similar saprolite in the Horse Heaven area in the Blue Mountains (Figure 1) and suggested that it also marked the top of the Clarno Formation at that locality. However, Peck (1964) and Swanson and Robinson (1968) placed the contact between the two formations in the western facies at the base of a widespread ash-flow tuff (member $A$ of the western facies) which unconformably overlies rocks of Clarno lithology and is several hundred feet stratigraphically above the Horse Heaven saprolite. At most localities the John Day Formation is unconformably overlain by basalts of the Columbia River Group. Where these are missing, the formation is unconformably overlain by younger units such as the Madras Formation, the Mascall Formation, or Quaternary basalt.

\section{Eastern Facies}

Merriam (1901) defined three members in the eastern facies of the John Day Formation based largely on color. However, most of the features used by Merriam to distinguish the members from one another vary laterally and define alteration facies rather than stratigraphic units. Hay (1962a; 1963) proposed a 3-fold subdivision based on the presence of a widespread ash-flow sheet (Picture Gorge Ignimbrite) near the middle of the Formation. Fisher and Rensberger (1972) divided the unit into four members, nearly comparable to those originally defined by Merriam (1901). From oldest to youngest, these are; a) the Big Basin Member, a basal sequence of red claystone, b) the Turtle Cove Member, characterized by green, buff, or pale red zeolitized tuff and tuffaceous claystone, c) the Kimberly Member characterized by light gray to buff, unzeolitized tuff and tuffaceous sediment and, d) the Haystack Valley Member composed of gray, largely fluviatile, volcaniclasti rocks. Several of the members, particularly the Kimberly and Big Basin members, are distinguished largely on the basis of diagenetic features and, hence, the contacts often transgress time-stratigraphic boundaries.

Big Basin Member - The Big Basin member is a thin, discontinous sequence of red and less abundant yellow tuffaceous claystone named for exposures in Big Basin. It is typically 15 to 40 meters thick but ranges from 0 to 75 meters. Locally, thin, discontinuous olivine basalt flows occur near its base. The claystones are poorly bedded, and crop out in low, 


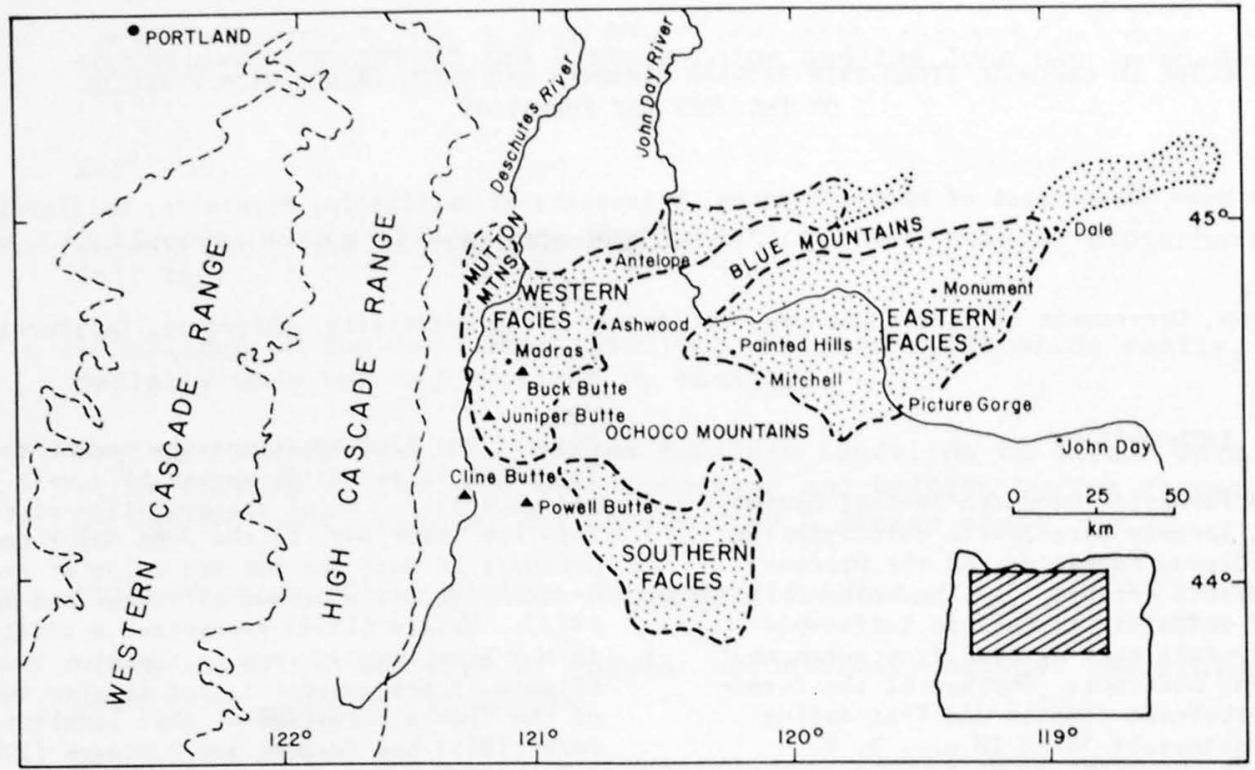

Figure 1. Index map showing approximate outcrop extent of the John Day Formation in north-central Oregon. Dashed lines enclose areas of known outcrop, dotted lines areas where rocks of probable John Day affiliation are present.

rounded hills mantled by a thin "popcorn-textured" layer. The red color of most of the unit is due to incorporation of red saprolite from local exposures of the Clarno Formation and diagenetic alteration of air-fall tuff in well-drained upland areas. Yellow coloration formed in the tuffaceous claystone where drainage was poor and there was less opportunity for iron oxidation (Hay, 1962a; Fisher and Rensberger, (1972).

Turtle Cove Member - The Turtle Cove member is the thickest and most widespread unit in the eastern facies of the Formation. Throughout most of the area it ranges from about 120 to 350 meters in thickness but it thins markedly northward against the Blue Mountain uplift where it is less than 15 meters thick (Fisher, 1967). It consists chiefly of varicolored, zeolitized, mostly fine-grained tuff and tuffaceous claystone with less important air-fall and ash-flow tuff. Outcrops in the lower part of the member display a typical ribbed or pinnacled 'badland' topography; those higher in the unit are smooth and rounded. Colors vary widely, reflecting varying degrees of diagenetic alteration. Most of the unit is light green with thin interbeds of light gray material; however, brown, yellow, and light red colors are common. The zeolitized tuffs and tuffaceous claystones were originally composed largely of vitric shards and pumice fragments. Pumice fragments are generally less than $1 \mathrm{~mm}$ in length but range up to 4 $\mathrm{mm}$. Sand-size crystals and rock fragments comprise 5-10 percent of most specimens. Crystals are chiefly andesine feldspar with lesser amounts of oligoclase, labradorite, and sanidine. Pyroxene, hornblende, biotite, magnetite, and ilmenite are usually present in trace amounts. Ouartz is rare except in a few rhyolitic air-fall tuffs in the lower part of the formation. One such tuff, exposed in the Painted Hills area, contains abundant large soda-rich sanidine crystals mantled with myrmekite. This layer, generally less than 1 meter thick, is believed to be the air-fall equivalent of a distinctive crystal-rich ash-flow tuff (member G) in the western facies (Hay, 1963; Woodburne and Robinson, 1977).

The Picture Gorge Ignimbrite is a composite ash-flow sheet, up to 75 meters thick, composed of two cooling units (Fisher, 1966a). It is typically coarsegrained, moderately to densely welded, and crystal poor. Crystals average less than 2 modal percent and consist of plagioclase, sanidine, quartz, and minor clinopyroxene.

Kimberly Member - The Kimberly member consists of gray to yellow gray, unzeolitized tuff and tuffaceous claystone similar to that of the underlying Turtle Cove member. The boundary between the two members is drawn almost entirely on a color change reflecting variations in diagenetic alteration and is chronologically variable.

The Kimberly member has a composite thickness of about 300 meters but the thickness varies considerably because of the variable lower boundary and because erosion in late John Day time stripped of $f$ much of the unit. Outcrops are usually smooth, even slopes often covered with light gray, powdery soll. Generally, the rocks form thick, poorly bedded, featureless sections without distinct marker units. 
Crystals comprise about 5 modal percent of these rocks and are chiefly andesine feldspar with minor amounts of clinopyroxene, magnetite, hornblende, piotite, and ilmenite. The absence of quartz and sanidine suggests an andesitic to dacitic composition. One distinctive rhyolite tuff characterized by abundant black obsidian shards occurs near the base of this member (Hay, 1963; Fisher and Rensberger, 1972).

Haystack Valley Member - The Haystack Valley member comprises a sequence of interbedded fluviatile and lacustrine tuffaceous sediments near the top of the formation. It has a maximum thickness of about 150 meters. The member consists largely of unzeolitized conglomerate, sandstone, and siltstone with some lacustrine tuff. Massive air-fall tuffs are commonly interbedded with the reworked and cross-bedded sediments. Individual beds of conglomerate and sandstone are often lenticular, filling steep-walled channels cut into the underlying Kimberly member. The composition of the reworked material suggests that this unit was derived solely from erosion of the lower John Day Formation (Fisher and Rensberger, 1972).

\section{Southern Facies}

Little detailed work has been done in the southern facies, which lies south of the Ochoco Mountains. Reconnaissance studies indicate that this section is most like the eastern facies, consisting chiefly of fine-grained tuff and tuffaceous claystone but having two prominent ash-flow sheets in the area south of Prineville.

The southern facies has not been formally divided into members but lithologic variations are similar to those of the eastern facies. A sequence of red claystone occurs discontinuously along the base of the formation and is similar to the Big Basin member of Fisher and Rensberger (1972). The overlying tuffs and tuffaceous claystones can be divided into zeolitized and unzeolitized sections that correspond approximately with the Turtle Cove and Kimberly Members.

The lower welded tuff south of Prineville Reservoir is a light gray to reddish-gray, stony rhyolite. It ranges from about 5 to 15 meters thick, generally thinning from north to south. The tuff is densely welded with a good eutaxtic structure, having flattened pumice fragments up to $10 \mathrm{~cm}$ long. Crystals comprise about $1-2 \%$ and are chiefly plagioclase with traces of magnetite and partly altered biotite. The matrix is a microcrystalline mixture of quartz and feldspar in which the original vitroclastic texture has been largely obliterated. Many of the larger pumice fragments have been zeolitized.

The upper ash-flow sheet is generally about 10 meters thick and consists of light gray to reddishgray, densely welded tuff. The tuff is relatively fine-grained and aphyric. Flattened pumice fragments, generally less than $1 \mathrm{~cm}$ long, define a crude eutaxtic structure. These are replaced by a mixture of tridymite, alkali feldspar, and zeolite. Small andesitic rock fragments comprise about 1 modal percent.
Nelther of these ash-flow sheets can be correlated with welded tuffs in the eastern or western facies and they are believed to have originated from separate vents south of the Ochoco Mountains.

\section{Western Facies}

In the area west of the Blue Mountains and east of the Cascade Range a sequence of largely pyroclastic rocks, 600 to 1200 meters thick, lies between the Columbia River Basalt and the Clarno Formation. This seqeuence consists largely of tuff and tuffaceous sediment compositionally similar to that of the eastern and southern facies of the John Day

Formation, but it also includes numerous basaltic to rhyolitic lava flows and silicic ash-flow tuffs. These rocks have been correlated with the type John Day Formation in the eastern facies on the basis of stratigraphic position and general lithologic similarity (Hodge, 1932; Waters, 1954; Peck, 1964; Swanson, 1969; Robinson, 1975; Woodburne and Robinson, 1977).

In the area west of the Blue Mountains the John Day-Clarno contact is placed just below the basal ash-flow sheet of member A. This ash-flow sheet lies unconformably on rocks of Clarno lithology and is locally separated from them by a thin, red saprolite.

Peck (1964) subdivided this sequence into 9 conformable members (A-I) based largely on the presence of ash-flow sheets and lava flows (Figure 2). This subdivision, with minor additions, is valid over most of the western facies (Robinson, 1975). The only major exceptions are in the area between Fossil and Lonerock and in the Mutton Mountains. In the Fossil area course-grained lapilli tuffs and dacitic to basaltic lava flows occur near the base of the formation. The stratigraphic position of these units is uncertain but they may be correlative with the upper part of the western facies. In the Mutton Mountains the only ash-flow sheet recognized is that of member G. Other ash-flow tuffs and lava flows are absent and the section cannot be further subdivided.

Member A - Member A is a widespread sequence of tuff, tuffaceous sediment, and welded tuff ranging in thickness from about 10 to 130 meters. At the base is a distinctive ash-flow sheet, up to 35 meters thick, that rests unconformably on the Clarno Formation. This is overlain by about 30 meters of poorly exposed lapilli tuff, tuff, and tuffaceous sediment which in turn is succeeded upward by a densely welded, fine-grained ash flow-tuff, usually less than 20 meters thick.

The basal ash-flow tuff is densely welded, relatively coarse-grained, and sparsely porphyritic. A thin, light gray vitrophyre occurs locally at its base but most of the unit is devitrified and sparsely 11thophysal. Two cooling units, each with a basal vitrophyre, are exposed along the county road west of Ashwood; elsewhere only one cooling unit can be recognized. The tuff is characterized by a well developed eutaxitic structure with flattened pumice lapilli up to $8 \mathrm{~cm}$ long. Crystals average $5-8 \%$ and consist chiefly of quartz, sanidine, and plagioclase; some specimens also contain traces of green hornblende and opaque minerals. Rock fragments, mostly andesite and rhyolite, comprise 0.5 to $2 \%$. 


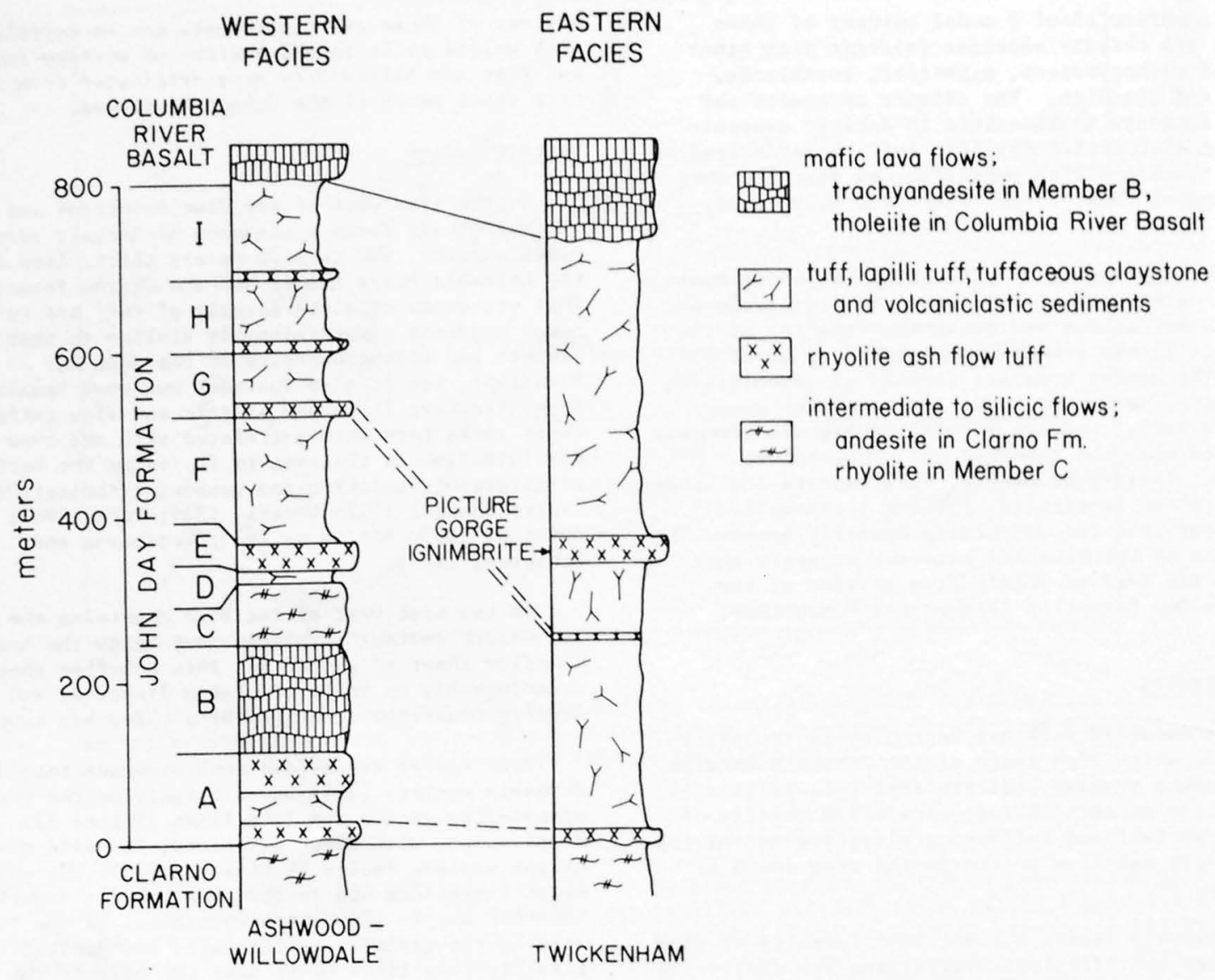

Figure 2. Generalized composite stratigraphic columns for the western and eastern facies of the John Day Formation showing probable correlations.

This is one of the most distinctive and widespread ash-flow tuffs in the western facies. It can be traced in nearly continuous outcrop from Grizzly on the south to the vicinity of Clarno on the north, a distance of nearly $80 \mathrm{~km}$. It has been recognized in isolated outcrops along the crest of the Blue Mountain uplift (Swanson and Robinson, 1968; Swanson, 1969 ) and in a small outcrop at the base of the eastern facies along Rowe Creek (Woodburne and Robinson, 1977). Correlations between these separate exposures are based on grain size, phenocryst assemblage, mineral compositions, and stratigraphic position.

Directly above the basal ash-flow tuff is a white, poorly bedded lapilli tuff containing abundant pumice. This is followed upward by red to yellowishbrown tuffaceous claystone and interlayered tuff locally containing numerous plant fossils. The upper ash-flow sheet is a light brown, fine-grained welded tuff with $1-2 \%$ plagioclase phenocrysts and $1-2 \%$ small rock fragments. A light gray vitrophyre occurs locally at the base but most of the unit is stony with very sparse lithophysae.
Member B - Member B is a series of dark gray trachyandesite flows that crop out chiefly in the Antelope-Ashwood area. This member is about 300 meters thick in the area west of Ashwood but the sequence thins gradually to the north and south from this point. A thinner sequence, probably no more than 30 meters thick, crops out in the Antelope Valley. Locally several flows can be recognized, separated by 5-6 meters of brown tuff and tuffaceous sediment. The trachyandesite typically fractures into angular, fist-size fragments, forming rounded outcrops mantled by talus.

The trachyandesite is very fine-grained and nearly aphyric. Small phenocrysts of olivine, replaced by smectite, lie in a matrix of tiny plagioclase laths, granular pigeonite, opaques, and abundant interstitial glass. One flow in Eagle Valley, south of Antelope, is holocrystalline and medium grained with an intergranular to subophitic texture. Vesicles are sparse except in thin zones at the tops of flows. 
Member C - A thick rhyolite flow and domal complex in the Ashwood-Antelope area comprises member $C$. The rhyolite flows, which are up to 125 meters thick along Wilson Creek, were probably erupted from the domal complex along Trout Creek, just north of Ashwood. The domal complex has crude, nearly vertical columnar jointing, variable flow banding, and a marginal rhyolite breccia interbedded with tuff along the southern edge.

Both the flows and the dome consist of light gray to purplish-gray, massive to flow banded, very sparsely porphyritic rhyolite. Phenocrysts of plagioclase and quartz comprise less than 2 modal percent and lie in a matrix of microcrystalline quartz and feldspar.

Member D - Member D is a thin, areally restricted sequence of tuff and lapilli tuff that lies above rhyolite flows of member $C$ and below ash-flow tuffs of member $\mathrm{E}$. The tuffs are light gray to yellowishgray, poorly indurated, and moderately bedded. A maximum thickness of about 30 meters is exposed along Pony Creek between Ashwood and Willowdale. At most localities the unit is less than 5 meters thick.

Member E - A series of densely welded, highly 1ithophysal ash-flow tuffs, up to 120 meters thick, comprise member E. These are best exposed along Pony Creek between Ashwood and Willowdale where they form steep, columnar-jointed outcrops. A light gray basal vitrophyre is exposed locally but most of the unit consists of stony rhyolite. Outcrops of crystallized tuff are characterized by abundant large lithophysae arranged in crude layers. The tuffs are very finegrained and generally lack any eutaxitic structure. Crystals of oligoclase and quartz comprise $1-2 \%$ and some specimens have trace amounts of altered pyroxene. Rock fragments are rare or absent. In many places the large lithophysal cavities have been filled with opal or chalcedony to form round or oval masses known locally as 'thunder eggs'. Peck (1964) included the weakly welded ash-flow tuff at the Priday agate deposit in the base of member $F$ but Robinson (1975) considered it to be the top of member E.

Member F - Member F consists of 100 to 300 meters of varicolored tuff, lapilli tuff, and tuffaceous claystone with interlayered basalt flows near the base. The pyroclastic rocks are poorly indurated and poorly exposed, often being involved in small landslides or covered with talus from ash-flow sheets in overlying members.

At the base of the member is a coarse-grained, well bedded pumice lapill1 tuff up to 3 meters thick. overlying this is a 50 - to 70 -meter-thick section of brick-red, poorly bedded, tuffaceous claystone. The claystone is followed upward by predominately yellow, gray, and green altered tuffs and lap1l11 tuffs.

In Antelope Valley numerous alkali-olivine basalt flows are interbedded with tuffs and tuffaceous claystones in the lower part of the member (Robinson, 1969). Individual flows are typically 5-10 meters thick and extend along strike for up to $20 \mathrm{~km}$. Outcrops are generally low, rounded hills mantled with small chips of weathered, yellow-brown basalt.

The basalts are usually holocrystalline, mediumto coarse-grained, and aphyric. They contain 10-15 percent olivine, mostly altered to smectite, abundant titaniferous augite, plagioclase, ilmenite, and minor interstitial alkali feldspar. Local pegmatitic segregations consist chiefly of titanaugite, ilmenite, and plagioclase. These highly titaniferous and alkalic basalts are chemically distinct from lava flows in the Clarno Formation, the Columbia River Basalt Group, and younger basalts in north-central Oregon (Robinson, 1969)

Member G - This member consist of a basal ash-flow sheet, about 15 meters thick, overlain by 30 to 120 meters of poorly bedded, poorly indurated tuff and lapilli tuff. The basal ash-flow sheet is typically reddish-brown, densely welded, and completely crystalized, forming resistant ridge-like outcrops. It is characterized by abundant large phenocrysts of soda-rich sanidine mantled by myrmekitic intergrowths of quartz and feldspar. It crops out chiefly in the Antelope-Ashwood-Willowdale area but a similar tuff occurs in the Mutton Mountains about $20 \mathrm{~km}$ west of Willowdale and an air-fall equivalent occurs in the eastern facies.

The ash-flow sheet shows systematic variations in thickness, degree of welding, and crystallization from south to north. In the vicinity of Hay Creek Ranch, east of Madras, the tuff ranges from about 15 to 30 meters thick and is densely welded, completely devitrified, and moderately lithophysal. Twenty kilometers to the north along Oregon Highway 206 between Willowdale and Antelope, the tuff is 5-6 meters thick, moderately welded, and completely glassy. Farther to the northeast, between Antelope and $\mathrm{Clarno}$, an air-fall tuff containing similar large crystals of soda-rich sanidine mantled with myrmekite occurs in the same stratigraphic position. In this area the air-fall tuff is usually about 1 meter thick but, where extensively reworked it may attain a thickness up to 10 meters. This air-fall tuff has been correlated with a similar tuff in the Painted Hills area east of the Blue Mountains (Hay, 1963; Woodburne and Robinson, 1977) and is believed to provide a tie between the eastern and western facies.

The tuffs and lapilli tuffs above the basal ashflow sheet are light gray to light brownish-gray, poorly bedded, and moderately to weakly indurated. Outcrops are poorly exposed, often being covered with talus from overlying ash-flow sheets. At the base, there is usually a 2- to 10-meter-thick sequence of lithic lapilli tuff, overlain by 20 to 30 meters of light brown, fine-grained tuff with about $5 \%$ white pumice lapilli, which give the rock a characteristic spotted apppearance. Locally, this is overlain by 5-6 meters of poorly bedded, light gray, fine-grained ash. At the top of the section is a sequence of poorly bedded, poorly indurated, light brown to light gray tuff, up to 50 meters thick.

Most of the tuffs and lapilli tuffs are crystal poor, containing 2-5\% plagiocase feldspar and traces of altered ferromagnesian minerals. Quartz and sanidine are rare to absent. Most specimens are diagenetically altered, containing abundant zeolite, chiefly clinoptilolite.

Member $\mathrm{H}$ - Member $\mathrm{H}$ consists of a 5- to 15-meterthick basal ash-flow sheet overlain by about 30 to 40 meters of weakly indurated tuff and lapilli tuff. The 
basal ash-flow sheet is very widespread cropping out almost continuously from the vicinity of Juniper Butte to the area northeast of Clarno (Figure 1). Generally, the tuff becomes thinner and less densely welded to the north and northeast. It is typically yellowish- to reddish-brown, very fine-grained, and very sparsely phyric. Crystals of sodic plagioclase and quart $z$ are present in trace amounts. At many localities there is a light gray, glassy layer at the base but most of the unit is devitrified. Outcrops east and south of Madras contain numerous 11thophysal cavities but such features are sparse elsewhere.

The overlying tuffs and lapilli tuffs are poorly exposed, forming low, talus-mantled outcrops. They consist chiefly of light brown to buff, very poorly bedded, fine-grained tuff. Most rocks contain $5-10 \%$ of small white pumice lapilli producing a distinct speckled appearance. Outcrops also contain thin layers of light gray, slightly more resistant tuff up to 0.5 meters thick. Crystals of plagioclase comprise $1-2 \%$ of most tuffs and small lithic fragments are sometimes present.

Member I - A basal ash-flow sheet, 20 to 50 meters thick, and an overlying 200- to 300-meter-thick sequence of tuff crops out extensively in the western facies from the area south of Madras to the vicinity of Fossil. Thicknesses vary considerably due to erosion at the top of the formation.

The basal ash-flow sheet is thickest and most densely welded in the area between Madras and Grizzly. Here it is consists of 50 to 60 meters of densely welded tuff with a thick, black vitrophyre at the base. It thins and becomes less densely welded to the north, being largely unwelded near Willowdale. the tuff is coarse-grained, containing large flattened or irregular pumice fragments and pieces of black obsidian. Small oligoclase crystals comprise about $1 \%$ and rock frgments, chiefly andesite and rare shist, make up $1-2 \%$.

The overlying tuffs are mostly light gray to yellowish-gray, poorly bedded, and massive, but a few layers are thinly bedded and cross-bedded. Outcrops are steep, even slopes often mantled with talus from the overlying Columbia River Basalt. The tuffs contain $1-2 \%$ crystals, chiefly andesine, sparse lithic fragments, and sometimes small pieces of black, vesicular glass. Tuffs in the lower part of the member are usually zeolitized but those in the upper 50 to 100 meters are still glassy but hydrated. These tuffs often contain well preserved vertebrate fossils (Woodburne and Robinson, 1977; Dingus, 1979).

Exposures of the John Day Formation between Fossil and Lonerock cannot be correlated directly with the facies but most of these rocks consist of fine-grained tuff similar to that in the upper parts of members $\mathrm{H}$ and $\mathrm{I}$. At the base of the sequence is a cream-colored to gray, relatively coarse-grained, poorly sorted, very poorly bedded, pumice lapilli tuff. The tuff has a maximum thickness of about 250 meters directly north of Fossil and thins to the northeast and southwest. No welding is observed in this unit but the poor sorting and lack of bedding suggest an ash-flow origin.
In the vicinity of Fossil several lava flows are interbedded with the basal tuff. West and north of Fossil is a reddish-brown rhyodacite (Robinson, 1969), 5 to 10 meters thick, with crude platy jointing. Farther east at least two flows of alkaliolivine-basalt occur at the same stratigraphic level,

This lower sequence is locally overlain by a thin, discontinuous welded tuff, possibly correlative with the basal ash-flow sheet of member $H$. The tuff is 3 to 5 meters thick and moderately to densely welded with a weakly developed eutaxitic structure, A thin layer of light gray glass occurs at the base of the tuff, passing upward into a weakly welded, reddish-gray, stony rock. Sparse crystals are chiefly oligoclase.

Above the welded tuff is a 200-to 300-meter-thick sequence of fine-grained, moderately indurated, poorly bedded tuff similar to that in the upper part of members $H$ and $I$. The uppermost tuffs contain small black fragments of fresh vesicular glass; those near the base are diagenetically altered and zeolitized.

\section{Correlation Of Eastern And Western Facies}

The western facies of the John Day Formation differs from the eastern facies in having generally coarser-grained air-fall tuffs and tuffaceous claystones and more abundant lava flows and ash-flow sheets. These differences are believed to reflect a western source for most of the pyroclastic material and the presence of a topographic barrier along the Blue Mountain axis through most of John Day time.

Two specific correlations between the eastern and western facies are proposed (Figure 2). A small outcrop of ash-flow tuff at the base of the eastern facies along Rowe Creek (Hay, 1963; Robinson, 1975) is correlated with the basal ash-flow sheet of member A in the western facies (Swanson and Robinson, 1968; Woodburne and Robinson, 1977). This correlation is based largely on phenocryst mineralogy, including the presence of a distinctive barium-rich sanidine (Woodburne and Robinson, 1977). If this correlation is correct it implies that uplift along this part of the Blue Mountains took place after about $36 \mathrm{~m} . \mathrm{y}$.

A distinctive rhyolitic air-fall tuff in the eastern facies (Hay, 1963) is correlated with the basal ash-flow tuff of member $G$ and its air-fall equivalent in the western facies. These tuffs are mineralogically similar, having abundant phenocrysts, 1-4 $\mathrm{mm}$ in diameter, of distinctive soda-rich sanidine mantled with myrmekite. This correlation suggests that the bulk of the western facies is equivalent to about the lower 75 meters of the eastern facies.

If these correlations are correct, the P1cture Gorge Ignimbrite has approximately the same stratigraphic position as the basal ash-flow sheet of member $\mathrm{H}$ of the western facies but these appear to be different units based on texture and mineralogy (Fisher, 1966). The general absence of ash-flow sheets in the eastern facies and thickness variations within the formation (Fisher, 1967) imply that the Blue Mountains formed a topographic barrier throughout middle and late John Day time. 
Table 1

Modal Analyses of John Day Rocks

\begin{tabular}{|c|c|c|c|c|c|}
\hline Groundmass & $\begin{array}{c}1 \\
92.7 a\end{array}$ & $97^{2} \cdot 6^{b}$ & $8^{3}$ & 4 & 5 \\
\hline Rock Fragments & 4.0 & 0.7 & 98.4 & 94.9 & 84.4 \\
\hline Sanidine & $\operatorname{tr}$ & - & 0.4 & - & 3.6 \\
\hline Quartz & $\operatorname{tr}$ & 0.3 & - & 1.1 & 10.1 \\
\hline Plagioclase & 2.3 & 1.4 & $\operatorname{tr}$ & 3.2 & 1.6 \\
\hline$($ An - Content $)$ & $35-40$ & 35 & 1.0 & 0.8 & - \\
\hline Clinopyroxene & - & - & $10-20$ & $20-25$ & - \\
\hline Hornblende & - & - & $\operatorname{tr}$ & - & - \\
\hline Biotite & $\operatorname{tr}$ & - & $\operatorname{tr}$ & $\operatorname{tr}$ & - \\
\hline Opaques & 0.2 & $\operatorname{tr}$ & - & - & - \\
\hline Zircon & $\operatorname{tr}$ & $t r$ & 0.1 & $\operatorname{tr}$ & 0.2 \\
\hline Apatite & $\operatorname{tr}$ & tr & $\operatorname{tr}$ & - & $\operatorname{tr}$ \\
\hline
\end{tabular}

1. Tuffaceous claystone and siltstone from western facies (average of $648-207,-52-9$, and $-52-11)$.
2. Vitric tuff from western facies $(648-57-6)$

3. Picture Gorge Ignimbrite, lower cooling unit (average of $648-458 \mathrm{a},-458 \mathrm{~b}$, and $-458 \mathrm{c}$ )

4. Basal ash-flow tuff of member A (Swanson and Robinson, 1968)

5. Basal ash-flow tuff of member G (average of 9 specimens)

a) includes 7.2 percent pumice fragments larger than $0.5 \mathrm{~mm}$

b) includes 4.7 percent pumice fragments larger than $0.5 \mathrm{~mm}$

- not recorded

\section{CHEMICAL COMPOSITION OF THE JOHN DAY FORMATION}

Rocks of the John Day Formation form three distinct mineralogical and chemical groups. Tuffaceous claystones and vitric tuffs are chiefly andesitic to dacitic, ash-flow tuffs and minor silicic lava flows are rhyolitic, and mafic lava flows are alkaliolivine basalt or trachyandesite.

Tuffaceous claystone and vitric tuff - The original composition of the tuffaceous claystone and vitric tuff cannot be determined directly by chemical analysis. Much of the original glassy material in these rocks has been replaced by montmorillonite or clinoptilolite during weathering before burial or by later diagenetic alteration. Chemical analyses of altered rocks reported by Hay (1963) indicate extreme hydration accompanied by leaching of $\mathrm{Na}_{2} \mathrm{O}$. Chemical analsyes of glassy material from the upper part of the formation are equally misleading because of extreme etching, bleaching, and hydration of the glass. The initial composition of the tuffaceous claystone and vitric tuff must therefore be inferred from the pyrogenic mineralogy. Crystals in these rocks are chiefly andesine feldspar with lesser amounts of labradorite, magnetite, pyroxene, hornblende, biotite, and ilmenite suggesting that the bulk of the material was originally andesitic to dac1t1c in composition (Table 1; Hay, 1962a; 1963; F1sher and Rensberger, 1972). Less abundant oligoclase-bearing tuff and tuffaceous claystone was probably rhyodacitic and a few tuffs in the lower part of the formation containing quartz, sanidine, and oligoclase were probably rhyolitic in compostion. These inferred compositions are supported by the presence of accessory andesitic, dacitic, and rhyolitic fragments in many of the samples.
Silicic ash-flow tuff - Ash-flow sheets in both the eastern and western facjes are rhyolitic, based on phenocryst 'mineralogy and whole-rock chemical analyses. Phenocrysts are primarily oligoclase, sanidine, and quartz with only traces of ferromagnesian minerals (Table 1). Chemical analyses indicate generally silicic compositions (Tables 2 and 3 ), however, the tuffs show very wide compositional variations. These perplexing chemical variations within individual ash-flow sheets have been noted by previous workers (Hay, 1963; Swanson and Robinson, 1968).

Numerous chemical analyses of the Picture Gorge Ignimbrite and the basal ash-flow sheet of member $\mathrm{H}$ indicate a consistent chemical alteration pattern that is dependent on the porosity and crystallinity of the tuff (Table 2). Very densely welded, devitrified zones with little or no observed primary porosity are interpreted to be the least altered parts of the ash-flow sheets. Within these zones analyses are consistent, alkali elements are subequal to each other, water contents are consistently low, and petrographic characteristics do not suggest dissolution of glass or deposition of secondary minerals. Other zones exhibit increasingly severe effects of alteration. Glassy zones are hydrated as indicated by water contents or volatile losses of 3 to 6 weight percent. Typically, hydrated vitrophyres contain less $\mathrm{SiO}_{2}, \mathrm{TiO}_{2}$, and $\mathrm{Na}_{2} \mathrm{O}$ and more $\mathrm{Fe}_{2} \mathrm{O}_{3}, \mathrm{CaO}$, and $\mathrm{K}_{2} \mathrm{O}$ than devitrified, densely welded tuffs. Alumina and $\mathrm{MgO}$ have no consistent pattern of loss or gain. With minor exceptions such as $\mathrm{Fe}_{2} \mathrm{O}_{3}$, the chemical differences between hydrated vitrophyres and devitrified, densely welded tuffs are similar to those reported for Nevada Test Site welded tuffs (Lipman, 1965). 
Devitrified, moderately to weakly welded or unwelded tuffs display different chemical changes that become increasingly severe as the porosity increases (Table 2; unpublished data). Typically, $\mathrm{SiO}_{2}$ increases and $\mathrm{TiO}_{2}, \mathrm{Al}_{2} \mathrm{O}_{3}, \mathrm{MgO}, \mathrm{CaO}$, and $\mathrm{Na}_{2} \mathrm{O}$ all decrease with increasing porosity of the sample. Both iron and potassium are somewhat higher in devitrified, moderately welded tuffs but decrease in more thoroughly silicified unwelded portions of the devitrified ash-flow tuffs.

Chemical changes in devitrified samples can be partially correlated with petrographic features. The loss of many elements is consistent with observed leaching of pumice lapil1i and phenocrysts from altered specimens. Iron content is largely controlled by secondary iron oxides that stain the rocks brick red or form liesegang banding. Very high potassium samples have minute euhedra of potassiumrich feldspar in the groundmass or in pumice lapilli, and very high silica rocks contain abundant prismatic quartz crystals in the groundmass and pore spaces.

The ash-flow tuffs are believed to have been altered by the same diagenetic event that affected the air-fall tuffs and tuffaceous claystones (Hay $1962 a ; 1963)$. The very different alteration of airfall and ash-flow tuffs is due largely to differences in texture. Densely welded non-porous vitrophyres exhibit chemical alteration typical of leaching by groundwater during hydration, such as that reported by Lipman (1965). The chemical effects are generally small, as might be expected for rocks with no primary porosity and little induced porosity.

Porous glassy material from unwelded basal zones of ash-flow sheets and enclosing tuffaceous claystones and vitric tuffs exhibit severe chemical changes induced by large volumes of groundwater acting on large surface areas. The low porosity and permeability of the vitrophyres precluded significant chemical reaction with the groundwater except possibly for hydration and minor leaching. Where cut by fractures that increased permeability and porosity, the vitrophyres have thin $(1-5 \mathrm{~cm})$, zeolitic alteration halos along the cracks (Hay, 1963).

Porous, partially welded to unwelded zones in the ash-flow tuffs must have been devitrified prior to diagenetic alteration; otherwise, secondary minerals similar to those in surrounding claystones and tuffs would be expected. Devitrified tuffs contain alkali feldspar and quartz in the groundmass whereas claystone and vitric tuff contain montmorillonite, celadonite, or clinoptilolite. The difference in secondary mineralogy of the welded tuffs and surrounding claystones is probably not due to differences in initial rock compositons because Hay (1963) reported zeolitic alteration of silicic as well as intermediate composition tuff.

The alteration of upper partially welded to unwelded zones is probabiy unrelated to vapor phase crystallization in the ash flows. This is inferred because typical vapor phase minerals such as tridymite are not commonly observed and quartz is the most abundant silica mineral. Minor chemical changes may have resulted from vapor phase activity, but these were overwhelmed by subsequent diagenetic alteration.
Assuming that our model of consistent chemical change as a function of sample porosity and crystallinity is correct, we can infer the original magma composition of altered units by comparing rocks of similar petrographic character. For example, a rhyolite compositon is inferred for the ash-flow sheet of member $E$, which has no known fresh material, by comparing its composition to petrographically similar altered material from the welded tuff of member $\mathrm{H}$ or from the Picture Gorge Ignimbrite (Table 2).

Chemical analyses of altered samples from other units suggest that all of the ash-flow tuffs in the John Day Formation were originally rhyolite in composition (Table 3). Certainly minor chemical differences between ash-flow sheets must have been initially present; however, these are masked by diagenetic alteration effects. In general, the ashflow tuffs appear to have been moderately alkali rhyolite with silica contents on the order of $75-76 \%$. These rocks appear to be chemically distinct from most of the vitric tuffs and tuffaceous claystones which make up the bulk of the formation.

Mafic lavas - Although the rocks are somewhat altered reliable chemical analyses have been obtained for most of the mafic lava flows in the formation (Table 4). Member B of the western facies is a trachyandesite with moderate $\mathrm{SiO}_{2}$ content. Equivalent rocks are not known in the eastern facies outcrops. Basalt flows in the western facies are all low silica, silica-undersaturated alkali-olivine basalt with high titania. Minor basalt flows in the lower part of the eastern facies have similar compositions.

The trachyandesites and alkali olivine basalts probably represent separate magma pulses, unrelated to each other or to the silicic rocks. They form distinct chemical groups and rocks of intermediate composition are not known. In addition, the high $\mathrm{Fe} 0 / \mathrm{MgO}$ ratios and $\mathrm{Fe}_{2} \mathrm{O}_{3}$ contents of the alkaliolivine basalts indicate an evolution along high-Fe tholefitic trends rather than along high silica lines toward trachyandesite compositions.

\section{ORIGIN OF THE JOHN DAY FORMATION}

Tuffs, lapilli tuffs, and tuffaceous claystones in the western, southern, and eastern facies are texturally similar to rocks that represent accumulation of ash falls on the land surface (Hay, 1962a; 1963; Fisher, 1966b). These rocks become progress1vely thicker and coarser-grained from east to west (Waters, 1954; Peck, 1964; Rob1nson, 1975), suggesting that the source volcanoes lay to the west of the present outcrops. The source volcanoes were largely andesitic to dacitic in composition based on pyrogenic mineralogy. No andesitic or dacitic volcanoes of John Day age are known in the John Day basin, east of the present day Cascades. Previously suggested vents in the Horse Heaven Mining District (Waters and others, 1951) and at Smith Rock (Williams, 1957) are unconformably overlain by John Day rocks (Swanson and Robinson, 1968; Robinson and Stensland, 1979) and are here considered to be Clarno in age. The absence of andesitic or dacitic vents in the John Day outcrop area, the evidence for a western source, and the similarity of these rocks to younger units suggest that the source volcanoes were located beneath the present day Cascade Range. This suggests that 
Table 2

Chemical Composition of Fresh and Altered Welded Tuff

Member E.

\begin{tabular}{cc} 
Member E \\
\hline 1 & 2
\end{tabular}

\begin{tabular}{|c|c|c|c|c|c|c|c|c|c|c|c|}
\hline $\mathrm{SiO}_{2}$ & 76.37 & 77.51 & 83.23 & 75.94 & 77.5 & 76.9 & 80.83 & 75.31 & 74.07 & 76.39 & 82.15 \\
\hline $\mathrm{TiO}_{2}^{2}$ & 0.21 & 0.21 & 0.17 & 0.26 & 0.17 & 0.16 & 0.17 & 0.39 & 0.25 & 0.35 & 0.24 \\
\hline $\mathrm{Al}_{2} \mathrm{O}_{3}$ & 12.03 & 11.39 & 8.74 & 13.07 & 12.2 & 11.61 & 11.33 & 13.08 & 13.08 & 12.46 & 9.22 \\
\hline $\mathrm{Fe}_{2} \mathrm{O}_{3}$ & 2.13 & 2.20 & 1.21 & 1.20 & 2.28 & 1.79 & 0.92 & 2.22 & 3.23 & 1.55 & 1.03 \\
\hline $\mathrm{MnO}$ & - & - & - & 0.02 & 0.09 & 0.03 & 0.01 & $\operatorname{tr}$ & 0.04 & 0.02 & 0.03 \\
\hline $\mathrm{MgO}$ & 0.11 & 0.06 & 0.02 & 0.07 & 0.35 & 0.03 & 0.04 & 0.25 & 0.19 & 0.10 & 0.04 \\
\hline $\mathrm{CaO}$ & 1.00 & 0.61 & 0.31 & 0.50 & 0.65 & 0.18 & 0.21 & 0.68 & 1.28 & 0.59 & 0.55 \\
\hline $\mathrm{Na}_{2} \mathrm{O}$ & 2.29 & 2.92 & 1.43 & 4.41 & 3.1 & 3.33 & 2.96 & 3.98 & 3.60 & 3.31 & 2.41 \\
\hline $\mathrm{K}_{2} \mathrm{O}$ & 5.09 & 4.47 & 4.77 & 4.19 & 3.7 & 5.08 & 3.38 & 3.95 & 4.28 & 5.14 & 4.03 \\
\hline $\mathrm{P}_{2} \mathrm{O}_{5}$ & - & - & - & 0.02 & 0.01 & 0.03 & 0.02 & 0.10 & 0.10 & 0.14 & 0.05 \\
\hline Total & $\overline{99.23}$ & $\overline{99.37}$ & $\overline{99.88}$ & $\overline{99.66}$ & $\overline{99.98}$ & $\overline{99.14}$ & $\overline{99.85}$ & $\overline{99.96}$ & $\overline{100.11}$ & $\overline{100.05}$ & $\overline{99.73}$ \\
\hline LOI & 3.74 & 1.02 & 1.12 & 0.86 & $6.0+$ & 0.42 & 0.64 & 1.00 & 4.03 & 1.04 & 0.90 \\
\hline
\end{tabular}

\begin{tabular}{|c|c|c|c|c|c|c|c|c|c|c|c|}
\hline & \multicolumn{3}{|c|}{ Member E } & \multicolumn{5}{|c|}{ Member $\mathrm{H}$} & \multicolumn{3}{|c|}{ Picture Gorge Ignimbrit } \\
\hline & 1 & 2 & 3 & 4 & 5 & 6 & 7 & 8 & 9 & 10 & 11 \\
\hline $\mathrm{SiO}_{2}$ & 76.37 & 77.51 & 83.23 & 75.94 & 77.5 & 76.9 & 80.83 & 75.31 & 74.07 & 76.39 & 82.15 \\
\hline $\mathrm{TiO}_{2}^{2}$ & 0.21 & 0.21 & 0.17 & 0.26 & 0.17 & 0.16 & 0.17 & 0.39 & 0.25 & 0.35 & 0.24 \\
\hline $\mathrm{Al}_{2} \mathrm{O}_{3}$ & 12.03 & 11.39 & 8.74 & 13.07 & 12.2 & 11.61 & 11.33 & 13.08 & 13.08 & 12.46 & 9.22 \\
\hline $\mathrm{Fe}_{2} \mathrm{O}_{3}$ & 2.13 & 2.20 & 1.21 & 1.20 & 2.28 & 1.79 & 0.92 & 2.22 & 3.23 & 1.55 & 1.03 \\
\hline $\mathrm{MnO}$ & - & - & - & 0.02 & 0.09 & 0.03 & 0.01 & tr & 0.04 & 0.02 & 0.03 \\
\hline $\mathrm{MgO}$ & 0.11 & 0.06 & 0.02 & 0.07 & 0.35 & 0.03 & 0.04 & 0.25 & 0.19 & 0.10 & 0.04 \\
\hline $\mathrm{CaO}$ & 1.00 & 0.61 & 0.31 & 0.50 & 0.65 & 0.18 & 0.21 & 0.68 & 1.28 & 0.59 & 0.55 \\
\hline $\mathrm{Na}_{2} \mathrm{O}$ & 2.29 & 2.92 & 1.43 & 4.41 & 3.1 & 3.33 & 2.96 & 3.98 & 3.60 & 3.31 & 2.41 \\
\hline $\mathrm{K}_{2} \mathrm{O}$ & 5.09 & 4.47 & 4.77 & 4.19 & 3.7 & 5.08 & 3.38 & 3.95 & 4.28 & 5.14 & 4.03 \\
\hline $\mathrm{P}_{2} \mathrm{O}_{5}$ & - & - & - & 0.02 & 0.01 & 0.03 & 0.02 & 0.10 & 0.10 & 0.14 & 0.05 \\
\hline Total & $\overline{99.23}$ & $\overline{99.37}$ & $\overline{99.88}$ & $\overline{99.66}$ & $\overline{99.98}$ & $\overline{99.14}$ & $\overline{99.85}$ & $\overline{99.96}$ & $\overline{100.11}$ & $\overline{100.05}$ & $\overline{99.73}$ \\
\hline LOI & 3.74 & 1.02 & 1.12 & 0.86 & $6.0+$ & 0.42 & 0.64 & 1.00 & 4.03 & 1.04 & 0.90 \\
\hline
\end{tabular}

\begin{tabular}{|c|c|c|c|c|c|c|c|c|c|c|c|}
\hline & \multicolumn{3}{|c|}{ Member E } & \multicolumn{5}{|c|}{ Member $\mathrm{H}$} & \multicolumn{3}{|c|}{ Picture Gorge Ignimbrit } \\
\hline & 1 & 2 & 3 & 4 & 5 & 6 & 7 & 8 & 9 & 10 & 11 \\
\hline $\mathrm{SiO}_{2}$ & 76.37 & 77.51 & 83.23 & 75.94 & 77.5 & 76.9 & 80.83 & 75.31 & 74.07 & 76.39 & 82.15 \\
\hline $\mathrm{TiO}_{2}^{2}$ & 0.21 & 0.21 & 0.17 & 0.26 & 0.17 & 0.16 & 0.17 & 0.39 & 0.25 & 0.35 & 0.24 \\
\hline $\mathrm{Al}_{2} \mathrm{O}_{3}$ & 12.03 & 11.39 & 8.74 & 13.07 & 12.2 & 11.61 & 11.33 & 13.08 & 13.08 & 12.46 & 9.22 \\
\hline $\mathrm{Fe}_{2} \mathrm{O}_{3}$ & 2.13 & 2.20 & 1.21 & 1.20 & 2.28 & 1.79 & 0.92 & 2.22 & 3.23 & 1.55 & 1.03 \\
\hline $\mathrm{MnO}$ & - & - & - & 0.02 & 0.09 & 0.03 & 0.01 & tr & 0.04 & 0.02 & 0.03 \\
\hline $\mathrm{MgO}$ & 0.11 & 0.06 & 0.02 & 0.07 & 0.35 & 0.03 & 0.04 & 0.25 & 0.19 & 0.10 & 0.04 \\
\hline $\mathrm{CaO}$ & 1.00 & 0.61 & 0.31 & 0.50 & 0.65 & 0.18 & 0.21 & 0.68 & 1.28 & 0.59 & 0.55 \\
\hline $\mathrm{Na}_{2} \mathrm{O}$ & 2.29 & 2.92 & 1.43 & 4.41 & 3.1 & 3.33 & 2.96 & 3.98 & 3.60 & 3.31 & 2.41 \\
\hline $\mathrm{K}_{2} \mathrm{O}$ & 5.09 & 4.47 & 4.77 & 4.19 & 3.7 & 5.08 & 3.38 & 3.95 & 4.28 & 5.14 & 4.03 \\
\hline $\mathrm{P}_{2} \mathrm{O}_{5}$ & - & - & - & 0.02 & 0.01 & 0.03 & 0.02 & 0.10 & 0.10 & 0.14 & 0.05 \\
\hline Total & $\overline{99.23}$ & $\overline{99.37}$ & $\overline{99.88}$ & $\overline{99.66}$ & $\overline{99.98}$ & $\overline{99.14}$ & $\overline{99.85}$ & $\overline{99.96}$ & $\overline{100.11}$ & $\overline{100.05}$ & $\overline{99.73}$ \\
\hline LOI & 3.74 & 1.02 & 1.12 & 0.86 & $6.0+$ & 0.42 & 0.64 & 1.00 & 4.03 & 1.04 & 0.90 \\
\hline
\end{tabular}

Member $\mathrm{H}$

1. 648-86, 648-S1-3, 648-S7-10, and DLP 58-50 (Peck, 1964): Hydrated glass.

3. 648-S1-4: Devitrified, weak1y welded.

4. 648-129A and 648-189: Devitrified, very densely welded

5. DLP 58-39A from Peck (1964): Hydrated glass.

6. 648-311: Devitrified, moderately welded.

7. 648-S4-10 and PTR 71-5b: Devitrified, weakly welded

8. \#3 Hay (1963): Devitrified, very densely welded, fresh.

9. 62-137 and 62-376 from Fisher (1966a); 非 Hay (1963); 648-455B: Hydrated glass.

10. 非 Hay (1963) and 648-458A: Devitrified, moderately welded.

11. 648-455C, 648-455D and 648-455E: Devitrified, unwelded.

- = not detected. 
Table 3

Chemical Analysis of Least Altered John Day Formation Ash-Flow Tuffs

\begin{tabular}{|c|c|c|c|c|c|c|c|c|}
\hline & Memher A & & Member $\mathrm{C}$ & Member $\mathrm{E}$ & Member $G$ & Member $\mathrm{H}$ & Member I & $\begin{array}{l}\text { Picture } \\
\text { Gorge }\end{array}$ \\
\hline $\begin{array}{l}\text { Lower } \\
\text { Basal }\end{array}$ & $\begin{array}{l}\text { Tuff } \\
\text { Upper }\end{array}$ & Upper Tuff & & & & & & Ignimbrite \\
\hline Cooling & Cooling & & & & & & & \\
\hline Unit & Unit & & & & & & & \\
\hline 1 & 2 & 3 & 4 & 5 & 6 & 7 & 8 & 9 \\
\hline 74.68 & 73.99 & 75.17 & 76.30 & 76.64 & 74.06 & 75.94 & 74.51 & 75.31 \\
\hline 0.25 & 0.61 & 0.20 & 0.29 & 0.18 & 0.37 & 0.26 & 0.25 & 0.39 \\
\hline 12.57 & 12.78 & 13.30 & 12.5 & 11.31 & 12.45 & 13.07 & 12.80 & 13.08 \\
\hline 2.9 & 2.11 & 1.77 & 2.17 & 2.69 & 3.41 & 1.20 & 2.66 & 2.22 \\
\hline- & 0.03 & 0.21 & 0.12 & 0.03 & 0.02 & - & 0.06 & $\operatorname{tr}$ \\
\hline 0.23 & 0.12 & 0.04 & 0.06 & 0.09 & 0.54 & 0.07 & 0.19 & 0.25 \\
\hline 0.65 & 1.01 & 0.59 & 0.46 & 0.76 & 1.09 & 0.50 & 0.88 & 0.68 \\
\hline 3.6 & 2.16 & 2.75 & 3.1 & 2.74 & 3.64 & 4.41 & 2.44 & 3.98 \\
\hline 4.38 & 6.49 & 6.08 & 5.1 & 4.71 & 4.37 & 4.19 & 5.70 & 3.95 \\
\hline- & 0.20 & - & 0.02 & - & 0.11 & 0.02 & - & .10 \\
\hline$\overline{99.26}$ & $\overline{99.30}$ & $\overline{100.14}$ & $\overline{100.12}$ & $\overline{99.10}$ & $\overline{99.99}$ & $\overline{99.66}$ & $\overline{99.46}$ & $\overline{99.96}$ \\
\hline 0.62 & 0.71 & 3.22 & 1.10 & 1.54 & 1.81 & 0.86 & 3.46 & 1.00 \\
\hline
\end{tabular}

*Total iron as $\mathrm{Fe}_{2} \mathrm{O}_{3}$

Sample Identification

1. 648-1a: partially devitrified, densely welded tuff

2. 648-1b: devitrified welded tuff with leached out pumice lapilli and minute quartz and alkali feldspar crystals in groundmass

3. 648-4a: hydrated, densely welded tuff

4. 648-27 and 648-S1-1: crystallized rhyolite flow with leached phenocrysts and quartz and alkali feldspar in groundmass

5. 648-41: devitrified, densely welded, lithophysal tuff with crystal-lined cavities; no thin section

6. 648-34: glassy, partially hydrated vitrophyre

7. 648-129A and 648-189: devitrified, very densely welded tuff with spherulites or very fine grained quartz and alkali feldspar

8. 648-5, 648-245, 648-S2-12: hydrated moderate to densely welded tuff with perlitic texture

9. Analysis 3, Hay (1963): devitrified, very densely welded tuff

Table 4

Average Chemical Composition of Mafic Lava Flows

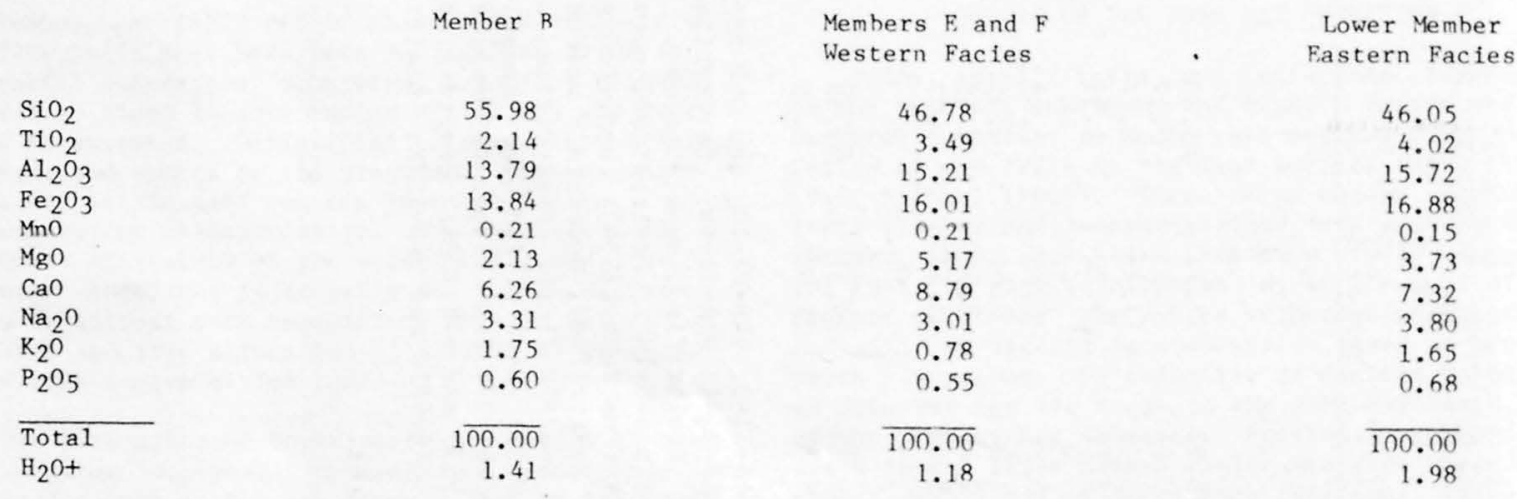

Notes: Member B: average of three analyses from Robinson (1969)

Members F and F: average of 11 analyses in western facies from Robinson (1969)

Lower Member: average of 2 analyses, in eastern facies (Rohinson, 1969). Outcrops are area below Picture Gorge Ignimbrite; however, corrrelation to western facies members is uncertain

All samples recalculated water free, all iron as $\mathrm{Fe}_{2} \mathrm{O}_{3}$ and totaled to $100 \%$ 
Cascade volcanism hegan ahout $36 \mathrm{~m} \cdot \mathrm{y}$. ago, and that the earliest phases of volcanism were compositionally similar to later ones.

The ash-flow tuffs of the John Day Formation are all rhyolitic in composition, distinctly different from most of the air-fall tuffs and tuffaceous claystones. Most of the ash-flow tuffs occur in the western facies and lateral variations in thickness, intensity of welding, grain size, and ahundance of lithophysae all suggest that they were derived from vents west or southwest of their present outcrops. Rhyolitic lava flows and ash-flow tuffs are absent in the western Cascades but numerous large rhyolitic domes occur in the area between the Cascade crest and the Blue Mountain uplift (Peck, 1964; Robinson, 1975; Swanson, 1969). Many of these, such as Powell Butte, Juniper Butte, and unnamed domes near Ashwood and in the Mutton Mountains are known to be John Day in age (Robinson and McKee, unpublished data); others are inferred to be on the basis of lithologic and compositional similarity. Although the ash-flow tuffs cannot be traced to specific vents, the domes and tuffs are compositionally similar and they probably represent the same phase of volcanism. Hence, nost of the ash-flows are believed to have been erupted from vents along the eastern margin of the present day Cascade Range and to have spread east and northeast into the John Day Basin. They are largely restricted to the western facies because the Blue Yountain uplift formed a topographic barrier between the eastern and western facies through most of John Day time (Robinson, 1975). The Picture Gorge

Ignimbrite in the eastern facies cannot be correlated with any of the ash-flow sheets in the western facies and is believed to have been erupted from an unknown vent in the Ochoco Mountains (Fisher, 1966a). These silicic volcanoes probably also account for the sparse rhyolitic air-fall tuffs and tuffaceous claystones in the lower part of the formation.

The alkali-olivine basalt and trachyandesite flows in the lower part of the formation are most abundant in the western facies in the AntelopeAshwood-Willowdale area, but they also occur east of the Blue Mountain uplift. These are mostly small, areally restricted flows, clearly of local origin. Scattered dikes and small accumulations of cinders probably mark vents from which some of these flows were erupted (Swanson, 1969; Robinson, 1975).

\section{SUMMARY}

The John Day Formation consists of three major lithologies, each derived from a different source. Andesitic to dacitic pyroclastic debris in the airfall tuffs and tuffaceous claystones was derived from volcanoes buried beneath the present day Cascades. Interbedded rhyolitic ash-flow tuffs, lava flows, and domes were erupted from vents lying just east of the Cascades and alkali-olivine basalt and trachyandesite flows were erupted from local vents throughout the John Day basin.

Our model for the evolution of volcanism in northern Oregon is as follows: During the Focene, andesitic volcanism of Clarno lithology was widespread in north-central Oregon, probably related to vents along the northeast-trending Blue Mountain uplift (Swanson, 1969). In the general area of the present day Cascades, marine sediments were being deposited along with minor basaltic rocks (Peck and others, 1964). Sometime between 40 and $36 \mathrm{~m} . \mathrm{y}$. ago, Clarno volcanism decreased in intensity, probably ending entirely by $36 \mathrm{~m} \cdot y$. Although the age of the uppermost Clarno rocks is not known exactly, no calcalkaline andesitic rocks of Clarno lithology are known in the John Day Formation.

Initiation of John Day volcanism about $36 \mathrm{~m} \cdot \mathrm{y}$. ago signified the emergence of a new volcano-tectonic regime in northern Oregon. Volcanoes in the vicinity of the present day Cascades began erupting andesitic to dacitic pyroclastic material that was deposited in the John Day basin as ash falls. This material represents the earliest documented volcanic activity along the Cascade trend. Simultaneously, vents east of the High Cascades, between the Cascade Range and the Blue Mountain uplift, were erupting rhyolite ash-flow tuffs, lava flows, and minor air-fall tuffs. Most of the ash-flow tuffs were derived from vents west of the present outcrops, whereas lava flows and domes represent local eruptions within the John Day basin. Other vents, mostly east of the major rhyolitic volcanoes, erupted alkaline basalt and trachyandesite.

This pattern of volcanism continued until approximately $25 \mathrm{~m} \cdot \mathrm{y}$. ago, at which time the rhyolitic, basaltic, and trachyandesitic eruptions ceased. Andesitic to dacitic eruptions continued in the Cascade Range leading to deposition of the upper part of the John Day Formation.

Deposition of the John Day Formation ceased about 18-20 m.y. ago (Woodburne and Robinson, 1977) coincident with a probable hiatus in Cascade volcanism (McBirney and others, 1974). Following a short period of folding and erosion, the Columbia River Basalt was erupted from vents in the eastern part of the John Day basin beginning about $16 \mathrm{~m} \cdot \mathrm{y}$. ago (Watkins and Baksi, 1974; McKee, Swanson, and Wright, 1977). Renewed volcanism in the Cascade Range is reflected in tuffaceous interbeds in the Columbia River Basalt and in post-Columbia River deposits such as the Mascall and Madras Formations.

The regional significance of the pattern of oligocene and early Miocene volcanism outlined above is not clear. The different magmas may reflect lateral variation in depth of magma generation, in crustal thickness or composition, or in tectonic environment.

\section{REFERENCES CITED}

Coleman, R. G., 1949, The John Day Formation in the Picture Gorge Quadrangle, Oregon: Unpub. M. S. thesis, Oregon State Univ., Corvallis, $211 \mathrm{p}$.

Brown, C. E. and Thayer, T. P., 1966, Geologic map of the Canyon city quadrangle, northeastern Oregon: U. S. Geol. Survey Misc. Geol. Inv. Map I-447.

Dingus, L. W., 1979, The Warm Springs Fauna (mammalia Hemingfordian) from the western facies of the John Day Formation, Oregon: Unpub. M.S. thesis, Univ. Calif., Riverside.

Evernden, J. F., Savage, D. E., Curtis, G. H. and James, G. T., 1964, Potassium-argon dates and the Cenozoic mammalian chronology of North America: Amer. Jour. Sci., v. 262, p. 145-198. 
Fisher, R. V., 1966a, Geology of a Miocene ignimbrite layer, John Day Formation, eastern Oregon: Calif. Univ. Pubs. Geol. Sci. v. 67, 59 p.

Fisher, R. V., 1966b, Textural comparison of John Day volcanic siltstones with loess and volcanic ash: Jour. Sed. Pet., v. 36, p. 706-718.

Fisher, R. V., 1967, Early Tertiary deformation in north-central Oregon: Am. Assoc. Petrol. Geol. Bul1., v. 51, p. 111-123.

Fisher, R. V., 1968, Pyrogenic mineral stability, lower member of the John Day Formation: Univ Calif. Pubs. Geol. Sci., v. 75,36 p.

Fisher, R. V. and Rensberger, J. M., 1972, Physical stratigraphy of the John Day Formation, central Oregon: Calif. Univ. Pubs. Geol. Sci., v. 101, p. $1-45$.

Fisher, R. V. and Wilcox, R. E., 1960, The John Day Formation in the Monument quadrangle, Oregon: U.S. Geol. Survey Prof. Paper 400-B, p. 302-304.

Hay, R. L., 1962a, Origin and diagenetic alteration of the lower part of the John Day Formation near Mitchell, Oregon: Geol. Soc. America, Buddington Memorial Memoir, p. 191-216.

Hay, R. L., 1962b, Soda-rich sanidine of pyroclastic origin from the John Day Formation of Oregon: Am. Mineral., v. 47, p. 968-971.

Hay. R. L., 1963, Stratigraphy and zeolitic diagenesis of the John Day Formation of Oregon: Univ. Calif. Pubs. Geol. Sci., v. 42, p. 199-261.

Hodge, E. T., 1932, Geologic map of north-central Oregon: Oregon Univ. Pubs., Geology Ser. v. 1, $7 \mathrm{p}$.

Lindsley, D. H., 1960, Geology of the Spray Quadrangle, Oregon, with special emphasis on the petrography and magnetic properties of the Picture Gorge Basalt: Unpub. Ph. D. thesis, Johns Hopkins Univ. Baltimore, Md., $236 \mathrm{p}$.

Lipman, P. W., 1965, Chemical composition of glassy and crystalline volcanic rocks: U. S. Geol. Survey Bul1. 1201-D, p. D1-D24.

McBirney, A. R., Sutter, J. F., Naslund, H. R. Sutton, K. G. and White, C. M., 1974, Episodic volcanism in the central Oregon Cascade Range: Geology, v. 2, p. 585-589.

McKee, E. H., Swanson, D. A., and Wright, T. L., 1977, Duration and volume of Columbia River Basalt volcanism, Washington, Oregon, and Idaho: Geol. Soc. America Abstracts with Programs, v. 9, no. 4. p. 463-464.

Merriam, J. C., 1901, A contribution to the geology of the John Day Basin (Oregon): Calif. Univ. Pubs. Dept. Geol. Bul1. v. 12, p. 269-314.

Peck, D. L., 1964, Geologic reconnaissance of the Antelope-Ashwood area, north-central Oregon, with emphasis on the John Day Formation of late Oligocene and early Miocene age: U. S. Geol. Survey Bul1. 1161-D, P. D1-D26.

Peck, D. L., Griggs, A. B., Schlicker, H. G., Wells, F. G., and Dole, H. M., 1964, Geology of the central and northern parts of the Western Cascade Range in Oregon: U. S. Geol. Survey Prof. Paper, $449,56 p$.

Robinson, P. T., 1969, High titania alkali-olivine basalt of north-central Oregon, U. S. A.: Contr. Mineral. Petrol., v. 22, p. 349-360.

Robinson, P. T., 1975, Reconnaissance geologic map of the John Day Fomation in the southwestern part of the Blue Mountains and adjacent areas, northcentral Oregon: U. S. Geol Survey Map I-872.
Robinson, P. T. and Stensland, D., 1979, Geologic map of the Smith Rock area, Oregon: U. S. Ceol. Survey Misc. Geol. Inv. Map I-1142.

Swanson, D. A., 1969, Lawsonite blueschist from north-central Oregon: in Geological Survey Research 1969, U. S. Geol. Survey Prof. Paper $650-B, p \cdot 8-11$.

Swanson D. A., 1969, Reconnaissance geologic map of the east half of the Bend quadrangle, Crook, Wheeler, Jefferson, Wasco and Deschutes Counties, Oregon: U. S. Geol. Survey Misc. Geol. Inv. Map I -568 .

Swanson, D. A., and Robinson, P. T., 1968, Base of the John Day Formation in and near the Horse Heaven mining district, north-central Oregon; in Geological Survey Research, 1969: U. S. Geol. Survey Prof. Paper 600-D, p. D154-D161.

Waters, A. C., 1954, John Day Formation west of its type locality (abst.), Geol. Soc. Amer. Bull., v, $65, p .1320$.

Waters, A. C., Brown, R. E., Compton, R. R., Staples, L. W., Walker, G. W., and Williams, H., 1951, Quicksilver deposits of the Horse Heaven mining district Oregon: U. S. Geological Survey Bull. 969-E, pp. 105-149.

Watkins, N. D. and Baksi, A. K., 1974, Magnetostratigraphy and oroclinal folding of the Columbia River, Steens and Owyhee basalts in Oregon, Washington, and Idaho: Am. Jour. Sci., v. 274 , p. $148-189$.

Williams, Howel, 1957, A geologic map of the Bend quadrangle, Oregon, and a reconnaissance geologic map of the central portion of the High Cascade Mountains: Oregon Dep. Geol. Min. Ind., in cooperation with U. S. Geological Survey, Scales $1: 125,000$ and $1: 250,000$.

Woodburne, M. O. and Robinson, P. T., 1977, A new late Hemingfordian mammal fauna from the John Day Formation, Oregon, and its stratigraphic implications: Jour. Paleo., v. 51, p. 750-757. 
ROADLOG FOR GEOLOGIC FIELD TRTP BETWEEN KIMBERLY AND BEND, OREGON

WITH EMPHASIS ON THE JOHN DAY FORMATION

Paul T. Robinson, Department of Farth Sciences, University of California Riverside, California 92521

MILES

$(0.35)$

0.35

$(0.40)$

0.75

$(0.60)$

1.35

(0.05)

1.40

(0.55)

1.95

(0.75)

2.70

(0.45)

3. 15

(0.40)

3.55

(0.60)

4.15

(1.15)

5. 30

(0.40)

7.10

(1.40)

5.7

$(0.55)$

7. 65
Kimberly. Turn left on Highway 19 toward Dayville and John Day.

Cross North Fork of John Day River.

High level pediment at 12 o'clock. These are common along the John Day River between Kimberly and Picture Gorge.

Stop 1 (Optiona1). Dike of Picture Gorge Rasalt cuts upper buff beds of the John Day Formation. Dike strikes about N. $30^{\circ} \mathrm{W}$. and is essentially vertical. It has fine-grained margin and complex joint pattern. Although dike is about 10 meters wide the intruded sediments show little baking and only moderate induration.

Stream gravels in roadcut on left.

Dike crosses road at this point.

Tuffaceous claystones and tuffs of upper John Day Formation in roadcut on left. From here to Picture Gorge roadcuts are mostly in John Day rocks.

High level pediments on both sides of John Day River ahead.

Picture Gorge dike on hillside east of John Day River at 2 o'clock.

Greenish tuffs and tuffaceous claystones of John Day Formation at 3 o'clock.

Stop 2 (Optiona1). Green beds of John Day Formation overlying Picture Gorge Ignimbrite on left side of road. The ignimbrite here is about 10 meters thick and exhibits platy jointing near base with massive, rounded outcrops above. Ignimbrite is moderately welded with eutaxitic structure defined by elongate pumice fragments. Quartz bipyramids and feldspar crystals comprise $1-2 \%$ and lithic fragments are sparse. Altered glass chips and fragments are also present. Ignimbrite is altered and zeolitized.

Good exposures of green tuffs and tuffaceous claystones of John Day Formation at 9 o'clock. Note characteristic erosion into pinnacles. Ledge is Picture Gorge Ignimbrite.

Good exposures of green tuffs and tuffaceous claystones of John Day Formation at 9 and $11 o^{\prime}$ clock. Ledges are slightly more resistant airfall tuffs interlayered with less resistant claystones.

Middle John Day beds at 2 to 3 o'clock with Picture Gorge Ignimbrite forming 


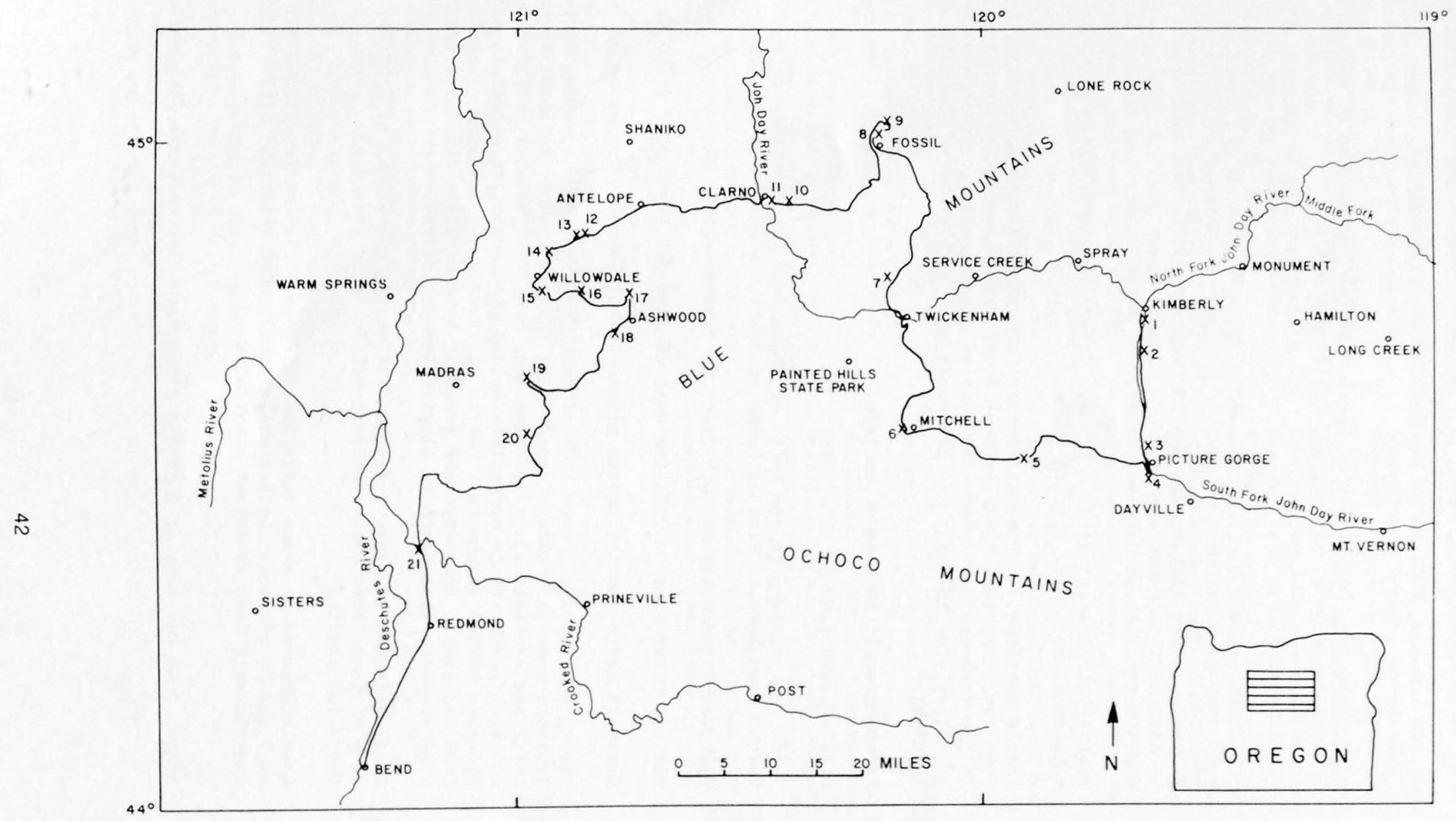

Figure 3. Index Map of north-central Oregon showing field trip route and locations of stops doscribed in text. 
prominent ledge. The ignimbrite is partlv slumped toward the river. Stream gravels in roadcut on left.

$(1.50)$

9.15

$(0.35)$

9.50

$(0.85)$

10.35

$(0.55)$

10.90

(1. 50)

$12.40)$

$(0.50)$

$12.90)$

(0.90)

13. 80

$(0.60)$

14.40

(0.50)

14.90

(2.15)

17.05

(1.60)

18.65

$(0.20)$

18.85

$(0.90)$

19.75

(0.45)

20.20

(1.20)

21.40

Fntrance to Foree Area of John Day Fossil Reds National Monument. Middle green portion of John Day Formation with ledge of Picture Gorge Ignimbrite crops out on both sides of river. Note slump blocks at 3 o'clock on west side of river.

Lower red tuffaceous claystones of John Day Formation at 9 o 'clock.

Large landslide blocks of Picture Gorge Basalt on both sides of the road.

Cathedral Rock at 1 o'clock shows ledge of Picture Gorge Ignimbrite interbedded with green tuffs and tuffaceous claystones of John Day Formation.

Ahead, dips in Picture Gorge flows define syncline plunging south (upriver).

Sheared serpentinite, presumably of Triassic age, Brown and Thayer (1966), left of road.

Fntrance to Turtle Cover Area, John Day Fossil Beds National Park. Type area of Turtle Cover Member of John Day Formation.

Bridge across river. Enter Picture Gorge Basalt, brought down by plunge of syncline.

Fault, south side up, brings Cretaceous conglomerates into contact with Picture Gorge Basalt. Conglomerates exposed on both sides of road at Goose Rock 0.5 miles to the south.

Stop 3. Sheep Rock on east side of river. Complete section of John Day Formation exposed here. Red beds on left (to the north) are the Big Basin Member resting on Cretaceous conglomerates. Overlying green tuffs and tuffaceous claystones make up Turtle Cover Member, characterized by extensive alteration and zeolitization. The Picture Gorge Ignimbrite occurs in the upper part of the Turtle Cover Member. The buff to tan beds in the upper part of the formation comprise the Kimberly Member, characterized by unzeolitized tuffs and tuffaceous claystones. This is overlain by two flows of Picture Gorge Rasalt. Note small normal faults offsetting Picture Gorge Ignimbrite, downdropped to the north.

Entrance to Picture Gorge. Location of type section of the basalt. The gorge is not named for the graffiti, some of it geologic in the form of painted numbers incorrectly designating the number of flows. Lowest exposed flow in roadcut on right.

Intersection with U.S. 26. Continue straight ahead through Gorge. Note many flow contacts.

Well exposed flow contact on right.

Leave gorge, with tuffaceous sedimentary rocks of Miocene Mascall Formation overlying Picture Gorge Basalt.

Turn right sharply onto Day Creek Road. Proceed 0.1 mile, turn right on dirt track and continue for several hundred feet to overlook. Stop 4. Dip slope of Picture Gorge Basalt to the north projects benearth valley of John Day River. Picture Gorge Rasalt unconformably overlain by Mascall formation with 
$(2.80)$

24.20

25.80

(1.90)

27.70

$(1.00)$

28.70

$(0.90)$

29.60

$(0.90)$

30.50

$(0.40)$

30.90

$(0.95)$

31.85

(0.30)

32.15

(1.75)

33.90

(2.05)

35.95

$(4.90)$

40.85

$(0.80)$

41.65

(1.00)

42.65

(1.90)

44.55

contact roughly parallel to river. Mascall Fomation unconformahlv overlain hy Rattlesnake Formation just west of Picture forge. Rattlesnake Formation consists of nrominent ash-flow sheet $(\sim 6 \mathrm{~m} \cdot \mathrm{v}$.$) lving hetween lavers of con-$ glomerate, each several hundred feet thick. Rattlesnake unconformablv overlaps Mascall Formation and rests on Picture Corge Basalt directlv above the gorge.

Return to I.S. 26 and Oregon 19 . Turn left and proceed northward back through the gorge.

Junction U.S. 26 and Oregon 19. Turn left toward Mitchell and proceed up Rock Creek. Road cuts are in Picture Gorge Basalt.

Contact of Mascall Formation and Picture Gorge Basalt in road cut on left. Ledge on top of hill at left is Rattlesnake welded tuff. For about the next 2 miles Rock Creek follows contact between Picture Gorge Basalt and Mascall Formation.

Fault crosses road, downdropping Mascall beds on north side. Road traverses basalt for next 0.3 miles and then passes into overlying Mascall Formation.

Fault crosses road, downdropping Mascall beds on north side and uplifting Picture Gorge Rasalt on south side. Road enters basalt again.

Picture Gorge Basalt and underlying sediments of John Day Formation. Good exposures of John Day rocks on right side of road at 3 o'clock. Road passes through poorly exposed outcrops of John Day Formation for about 1 mile.

Small outcrop of Cretaceous conglomerate on right side of highway.

Flows and breccia of Clarno Formation exposed in roadcuts on right hand side of highway. Roadcuts continue in the Clarno Formation for approximately the next 5 miles.

Pinnacles in gully on left side of highway are composed of Clarno laharic breccia.

John Day tuffs overlie laharic breccias of Clarno Formation south of stream. John Day beds largely obscured by slump blocks of overlying Picture Gorge Basalt.

Clarno laharic breccia on right side of highway is overlain by John Day tuffaceous sediment which in turn is overlain by Picture Gorge Basalt.

Picture Gorge Basalt overlying red sediments of John Day Formation. Road cuts for next 5 miles are in Picture Gorge Basalt as road climbs through section.

Junction of Antone Road and U.S. 26. Continue straight ahead. Ouarry south (left) of highway is in Picture Gorge Basalt. Ridge north of highway consists of Picture Gorge Basalt capped by Rattlesnake welded tuff. For about next 5.5 miles highway runs along top of Picture Gorge Basalt with Rattlesnake welded tuff exposed in hills on right hand side.

Tree covered ridge to south (left) is Ochoco Basalt resting on Rattlesnake Formation.

Stop 5 (Optional). Outcrop of Rattlesnake welded tuff on left. Glassy, fine-grained, moderately to densely welded tuff with a few large collapsed pumice fragments. Outcrop has well developed platy jointing.

John Day Formation in road cut with Rattlesnake welded tuff on hill to right. 
Rattlesnake welded tuff caps ridge to left. This is westernmost occurrence of this member in the John Day drainage.

$(0.60)$

47.90

(1.15)

49.05

$(1.90)$

50.95

$(1.70)$

52.65

$(1.90)$

54.55

$(0.20)$

54.75

$(0.25)$

55.00

$(0.35)$

55.35

$(0.95)$

56.30

$(0.25)$

56.55

$(0.75)$

57.30

(2.00)

59.30

(1.05)

60.35

(4.35)

64.70

$(0.70)$

65.40

(2.65)

68.05

$(0.80)$

68.85

(3.80)

72.65

(1.70)

74.35

$(0.45)$

74.80

Highly altered Clarno andesite on right side of road. Road cuts will be in clarno Formation for approximately the next 7 miles.

Keyes Summit. Keyes Mountain, an exhumed Oligocene volcano composed of Clarno andesite flows and breccias, can be seen at $2 o^{\prime}$ clock.

Clarno laharic breccia with very large andesite clasts on right side of road.

Platy Clarno andesite flow in road cut on right.

Turn off for Mitchell business loop. Continue straight ahead on U.S. 26 .

Contact of Clarno Formation and Cretaceous shales and conglomerates on right.

Junction Oregon 206 with U.S. 26. Continue straight ahead on U.S. 26.

Turn right on old highway. Stop 6. Examine Cretaceous sandstone and conglomerate. Continue on old highway for 0.40 miles to Oregon 206. Turn sharply left on 206 toward Service Creek and Fossil.

Contact of Clarno lava flows overlying Cretaceous rocks in roadcut on right.

Outcrop of Cretaceous sandstone, conglomerate, and shale. Clarno dike can be seen at 9 o' clock.

Roadcut in Cretaceous shales. Butte at $2 \mathrm{o}^{\prime} \mathrm{clock}$ is Clarno andesite on top of Cretaceous rocks. Straight ahead on skyline is Picture Gorge Basalt of Sutton Mountain.

On left are Permian (?) metasediments. Rocks include phyllites, marbles, and blueschists. (Swanson, 1969).

Hills on left are composed of Cretaceous conglomerate and sandstone.

Clarno andesites overlie Cretaceous rocks on right side of highway.

Junction of Oregon 206 with Twickenham Road. Turn left toward Twickenham. At right is narrow band of John Day sediments between Clarno Formation and Picture Gorge Basalt. For approximately next 7 miles the road traverses Sutton Mountain, a shallow syncline of Picture Gorge Basalt.

Hackly jointing in thick basalt flow on right.

Hackly jointing in thick basalt flow.

Twickenham Bridge across John Day River. This is on the west side of the Sutton Mountain syncline and Picture Gorge Basalt dips eastward with John Day rocks exposed beneath. Steep, cliff-forning flows at 12 o'clock and 2 o'clock are thick, hackly-jointed flows seen along road.

Hogback on right is Picture Gorge Ignimbrite interlayered with tuffs and tuffaceous claystones of John Day Formation. Numerous landslide blocks of Picture Gorge Basalt obscure the upper part of the John Day Formation.

Picture Gorge Ignimbrite exposed on right. White, resistant ledge below ignimbrite is rhyolite air-fall tuff with large soda-rich sanidine crystals 
$(1.05)$

75.85

$(0.90)$

76.75

(0.85)

77.60

$(0.35)$

77.95

(1.15)

79.10

$(0.40)$

79.50

$(1.25)$

80.75

$(0.40)$

81.15

(2.35)

83.50

(4.40)

87.90

$(0.75)$

88.65

(5.60)

94.25

(2.60)

96.85

$(0.80)$

97.65

THIRD DAY

$(0.05)$

0.05

$(0.50)$

0.55

helieved to be equivalent of ash-flow tuff of memher $c$ of western facies of John Day Formation.

Clarno lava flows on left underlie John Day Formation. Cood view on right of John Dav outcrops with Picture Corge Rasalt ahove.

Red tuffaceous claystones in road cut on left are lower John Day beds lying just above contact with Clarno Formation. At 12 o'clock are the buff and green tuffaceous sediments of the middle John Day.

Stop 7. Walk up gully for several hundred feet to outcrop of basal ash-flow tuff of John Day Formation. The tuff is moderately welded with a well developed eutaxitic texture. It contains about $5 \%$ phenocrysts, chiefly quartz and sanidine with minor plagioclase. Based on 1ithology, phenocryst mineralogy, and stratigraphic position this tuff is correlated with the basal ash-flow tuff of the western facies of the John Day Formation (Swanson and Robinson, 1968; Woodburne and Robinson, 1977).

Red tuffaceous claystone of basal John Day Formation resting on platy Clarno lava flows. Road follows the contact for about the next 1.5 miles.

Basal ashflow tuff of John Day Formation is exposed at end of dam. Clarno andesite flows crop out across the reservoir, on left.

The Clarno-John Day contact rises to the right and the road enters Clarno outcrops. Road cuts will be in Clarno Formation from here to town of Fossil. High peak at $90^{\prime}$ clock is clarno mafic intrusion.

Red claystones and laharic breccias on left are interlayered with Clarno andesite flows.

High peak at 12 o'clock is Rancherie Rock. This is a porphyritic hornblende andesite plug in Clarno Formation.

Junction with Oregon Highway 19. Turn left toward Fossil.

Butte Creek Summit. Good outcrops of Clarno andesite on both sides of highway.

Kinzua road junction. Continue straight ahead toward Fossil.

Tuffaceous claystones of Clarno Formation, in road cut on right.

Junction Oregon 19 and 218. End 2nd day.

Trip log resumes at junction of Oregon Highway 19 and 218. Continue straight ahead on Highway 19.

Junction Highway 19 and 218. Continue straight ahead on Highway 19.

Outcrop on right is Clarno andesite. Hills at 12 o'clock are Yakima Basalt overlying John Day Formation. 
Butte Creek turnoff. Continue straight ahead on Highway 19. Good exposures of Columbia River Basalt occur along Butte Creek. Picture Gorge and Yakima Basalt interfinger near mouth of Butte Creek where it enters John Day River.

Red tuffaceous claystone in roadcut marks Clarno-John Day contact.

Outcrops in roadcut are rhyodacite flow interlayed with lapilli tuffs of the John Day Formation.

Junction of old highway. Turn right on Hoover Creek road.

Stop 8. Examine rhyodacite flow and lapilli tuff of John Day Formation. The lapilli tuff is probably an unwelded ash-flow deposit. It cannot be correlated with any other ash-flow sheets in the John Day Formation and is restricted to the area northwest of the Blue Mountain uplift.

Road junction--stay on paved road toward Mayville. Note outcrops of Yakima Basalt ahead and to the right, characterzied by stone rings and stripes. Note difference in outcrop character between Yakima and Picture Gorge Basalts.

Stop 9 (Optional). Outerop on right is light colored, poorly bedded tuffaceous claystone of upper John Day Formation. This sequence is typical of the upper John Day in the area west and north of the Rlue Mountains.

Junction with Oregon Highway 19. Turn left, back toward Fossil. Road crosses Basalt-John Day contact and enters exposures of John Day Formation.

Road junction Oregon Highways 19 and 218. Turn right on Highway 218 toward Antelope and Shaniko. Road cuts for next 19 miles will be in Clarno Formation.

Stop 10 (Optional). Clarno Unit, John Day Fossil Beds National Monument. Steep cliffs are Clarno mudflow brecia. This sequence is better bedded and more stratiform than most of the Clarno Formation.

Entrance to Camp Hancock, run by Oregon Museum of Science and Industry. Locality of the famous Clarno 'nut' beds--numerous plant and vertebrate fossils in the upper Clarno Formation.

Cliffs on both sides of highway are basal John Day welded tuff overlying red tuffaceous claystones of upper Clarno Formation.

Stop 11. Basal welded tuff of member A of the John Day Formation is exposed in road cut. From here the unit can be traced, in almost continuous outcrop, to Grizzly, a distance of nearly 50 miles. The unit extends 3-4 miles east of this point, where it is overlapped by younger members of the John Day Formation. This unit is taken as the base of the John Day Formation in the Clarno-Ashwood-Antelope area, the type area of the western facies of the Formation. In this outcrop the tuff is fairly densely welded, devitrified, and somewhat richer in lithic fragments than elsewhere. Rock contains about $5 \%$ crystals--quartz, sandine, and plagioclase.

High peak to north on right hand side of John Day River is Ironside Mountain, underlain by Yakima Basalt with at least one flow of Picture Gorge Basalt at base. The Columbia River Rasalt rests unconformably on the John Day Formation. The ledge extending toward the river from the base of Ironside Mountains is composed of alkali-olivine basalt flows interbedded with tuffaceous sediments of the John Day Formation, member F. The entire area west of the John Day River is a large landslide in which blocks of Columbia River Basalt are mixed with tuffaceous sediments of the John Day Formation. One block of Columbia River Basalt, about $3 \mathrm{~km}$ long, 
(0.80)

27.55

(0.40)

27.95

(6.65)

34.60

(0.70)

35.30

(0.50)

35.80

(2.85)

38.65

(3.15)

41.80

(0.55)

42.35

$(0.55)$

42.90

(1.40)

44.30

(1.35)

45.65

(0.65)

46.30

(3.15)

49.45

(0.70)

50.15

(2.30)

52.45

$(0.35)$

52.80

moved as a coherent hlock. Note general hummocky topography and numerous slump blocks.

Clarno Rridge across John Dav River.

Basal ashflow tuff of John nay Formation in roadcut on right hand side. Note overlying tuffaceous sediments of member F. From here road traverses landslide area for next 7 miles.

Outcrops in cliffs on right are basalt flows of John Day Formation (member F) overlain bv basal ash-flow sheet of member $\mathrm{H}$.

White tuffaceous sediments of member F, John Day Formation in roadcut on left.

Crest of hill between John Day Valley and Antelope Valley. White tuffaceous sediments of member $F$ in roadcuts. Cliffs at 8 and 12 o'clock are Yakima Basalt overlying John Day Formation. Road cuts are in landslide material for approximately next 3.5 miles.

Road junction--continue straight ahead on Highway 218 . Rim on skyline ahead is edge of Columbia Plateau. Irregular hills in foreground are slump blocks of Yakima Basalt.

Road cut on left is prohably trachyandesite of member R, John Day

Formation. Trachvhasalt is difficult to distinguish chemically or mineralogically from Yakima Rasalt but here appears to underlie John Day sediments.

Antelope Road junction. Turn left toward Willowdale and Madras.

Low brown hills on right are alkali-olivine basalt flows of member F, John Day Formation.

John Day basalt on right. Lithophysal welded tuff of member F, John Day Formation, overlies rhyolite flow of member $C$ on left.

Welded tuff of member $E$ on left.

Welded tuff of member $\mathrm{E}$ in road cut on left. Road follows contact of member $\mathrm{E}$ and $\mathrm{F}$ for about next 3 miles. Brownish hills on right are John Day basalt capped by Yakima Rasalt.

Stop 12. Alkali-olivine basalt flow interbedded with tuffaceous sediments of member F, John Day Formation. Basalt is aphyric with medium-grained ophitic texture. Some pegmatitic segregations are complosed of large ilmenite and clinopyroxene crystals. Several shear zones cut basalt.

Stop 13. Outcrop of gray, weakly welded ashflow tuff of member G, John Day Formation. Note abundant large soda sanidine crystals, sparse lithic fragments, and slightly collapsed pumice lumps. Eastward from this point the unit is an airfall tuff; to the southwest it passes into densely welded, devitrified tuff. Note brown weathering color of John Day basalt at 9 o'clock. High hills at 10 and 11 o'clock are Yakima Rasalt overlying John Day Formation. Basal ash-flow tuff of member $G$ is overlain by bedded tuffaceous sediments. At 12 o'clock, the low ledge just above the road is the basal ash-low sheet of member $\mathrm{H}$.

On left, Yakima Rasalt cuts down into John Day Formation in old valley or topographic depression. Note columnar jointing in basalt at $12 o^{\prime}$ clock.

Approximate contact of Yakima Basalt and John Day Formation. Roadcuts are in 
(0.30)

53.10

(1.35)

54.45

$(0.95)$

55.40

(0.40)

55.80

(0.15)

55.95

57.20

(0.90)

58.10

(0.80)

58.90

(0.70)

59.60

(1.90)

61.50

(0.75)

62.25

(1.00)

63.25

(1.95)

65.20

(1.15)

66.35

$(0.95)$

67.30

(1.20)

68.50

Yakima Rasalt for next 1 mile.

Fault in Yakima Rasalt at 11 o'clock; left side down.

Hogbacks dipping to west (right) at 1 o'clock are John Day welded tuffs uplifted by major fault. Road cuts on left are landslide blocks of Yakima Basalt.

Low ledges on both sides of road are basal ash-flow sheet of member I, John Day Formation.

Junction with U.S. 96--turn right.

Stop 14. Basal ash-flow tuff of member I; unwelded glassy tuff characterized by high percent of lithic fragments, abundant pumice lumps, and glass chips and fragments. Contains $1-2 \%$ crystals, chiefly plagioclase. Unit becomes thicker and more densely welded to the south.

Road junction--turn right on old highway.

Road junction--turn right and return to U.S. 97.

Junction U.S. 97--turn left toward Willowdale.

Willowdale

Road junctjon--turn left toward Ashwood. Ledge on right after turn is basal welded tuff of member $H$, involved in a small fold.

Stop 15 (Optiona1). Examine ledge of welded tuff of member H. Rock is red, very fine-grained ash-flow tuff. Unit is not highly welded but is well indurated. Contains very sparse plagioclase phenocrysts and rare rock fragments. Locally, glassy base is preserved. Ahead at $120^{\prime}$ clock is landslide lobe which moved down from outcrops on skyline.

Ahead at 12 o'clock is dip slope of lithophysal welded tuff of member E, John Day Formation, bounded by fault on far side. Hogback at 9 o'clock is basal welded tuff of member $H$ with a glassy base and crystallized top. This is overlain at $80^{\prime}$ clock by basal welded tuff of member I with a thin zone of intervening sediments. Above basalt tuff of member I are tuffaceous sediments, mostly claystones with small pumice lapilli. Hill is capped by Yakima Rasalt.

Road crosses major fault at this point--west (left) side up. At $9 o^{\prime} \mathrm{clock}$ flat-lying welded tuffs of member $E$ cap the rhyolite flow of member $C$, separated by small amount of tuffaceous sediment of member D. Just to left of this outcrop the entire sequence dips westward about $40^{\circ}$, uplifted by fault. From here to Ashwood the road will generally go down section through the John Day Formation and into the Clarno. Road cuts for next 2.2 miles will be in member $F$ with landslide blocks of welded tuff from members $G$ and H.

Pony Butte at $4 \mathrm{o}^{\prime}$ clock is capped by basal welded tuff of member $\mathrm{H}$. Lower ledge is basal welded tuff of member $G$.

Contact of tuffaceous sediments of member $F$ and welded tuff of member E. For approximately next 5 miles roadcuts will be in lithophysal tuff of member E.

Stop 16. Examine outcrops of lithophysal tuff of member E. Rock is finegrained, densely welded crystallized tuff containing sparse plagioclase phenocrysts and rare rock fragments; locally has glassy base. Abundant lithophysae form layers alternating with massive portions of the tuff but 
(1.20)

69.70

$(0.85)$

70.55

(1.45)

72.00

$(0.50)$

72.50

$(0.30)$

72.80

$(0.10)$

72.90

$(0.10)$

73.00

(1.50)

74.50

$(0.90)$

75.40

$(0.90)$

76.30

(1.75)

78.05

(2.10)

80.15

$(1.20)$

81.35

(1.05)

82.40

$(0.70)$

83.10

$(0.60)$

83.70

$(0.70)$

84.40

sometimes they occur in vertical swarms. This tuff varies greatly in thickness and appears to fill a local topographic depression on rhyolite flow of member $C$.

Major outcrop of tuff and tuffaceous sediments of member $D$ beneath welded tuff of member F. For next 0.2 miles welded tuff thins rapidly to east and northeast.

Road now runs on top of member F. Low hills on left are rhyolite flow of member $C$.

Base of member $E$ resting on trachyandesite flow of member $B$, John Day

Formation.

Layer of sediment separating trachyandesite flows of member $B$.

Contact between trachyandesite of member $B$ and reddish tuffaceous sediments of middle part of member A.

Basal welded tuff of member $A$.

Contact between John Day and Clarno Formations. Road cuts will be in Clarno to bottom of valley. Note red zone at top of Clarno--this saprolite is discontinuous and less well-developed in this area than in the area east of the Blue Mountains.

Road bends to right. Turn left on dirt road and proceed 0.90 miles to end of road.

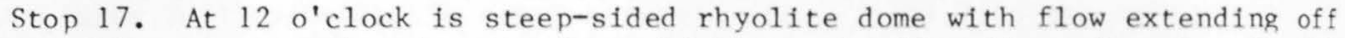
to right. Dome marks the vent from which the rhyolite flow of member $\mathrm{C}$, John Day Formation, was erupted. Note crude columnar jointing in dome. Coarse boulder lahar on left is in Clarno Formation. Return to highway.

Junction with paved road. Continue straight ahead toward Ashwood.

Ashwood Road junction--turn right on gravel road toward Hay Creek and Grizzly.

Contact of John Day and Clarno Formations in roadcut on right. Stop 18. Bus will proceed 0.35 miles up road and park. Road traverses a complete section of member A of John Day Formation. Rasal ash-flow sheet exhibits two cooling units, mineralogically and petrographically similar. This is overlain by a sequence of poorly exposed lapilli tuffs and tuffaceous claystones which are capped by upper fine-grained ash-flow tuff of member A. Entire section overlain by trachyandesite of member $B$.

Top of hill. Road junction--continue straight ahead and follow left hand fork. Tuffaceous sediments of member $D$ are exposed in roadcut. Here member I lies between trachyandesite of member $B$ and lithophysal tuff of member $E$. From this point the road runs approximately south and roughly parallels the contact between members $B$ and E crossing back and forth for next 5.5 miles.

Contact of members $B$ and $E$ in roadcut on right.

Contact of members $B$ and $E$ in roadcut on left.

Contact of members $B$ and $E$ in roadcut on left.

Contact of members $B$ and $E$ in roaduct on right. Ledge on right is member $E$, much thinner here than in Pony Creek Canyon. Minor amounts of tuffaceous sediments of member D lie beneath member in roadcuts for the next 0.5 miles. 
Fxcellent view of High Cascade peaks on right. Double butte in foreground is

$(0.20)$

85.60

$(0.40)$

86.00

(1.30)

87.30

$(0.45)$

87.75

(2.10)

89.85

$(0.50)$

90.35

(1.35)

91.70

(2.85)

94.55

$(0.45)$

95.00

(0.95)

95.95

(1.40)

97.35

(1.15)

98.50

(0.65)

99.15

(1.15)

100.30

(1.50)

101.80

(0.35)

102.15

$(0.70)$

102.85

Teller Butte--capped with welded tuff of member G.

Contact of members $B$ and $F$ in roadcut on left

Sediments between trachyandesite flows of member $B$.

Welded tuff of member $F$. overlies member $B$ in roadcut on left. Welded tuff of member $F$, forms prominent ledge dipping northwest on hill at 2 o'clock. Just ahead, where road swings left, the hill at 1 o'clock is capped with welded tuff of member $G$.

Tuffaceous sediments of member $F$ are exposed in roadcuts on right. Roadcuts are in member $F$ for approximately next 4 miles.

White pumice lapilli tuffs in roadcut on right are near the base of member $F$. Good exposures of member $F$ occur on hill at $80^{\prime} \mathrm{clock}$. These are mostly red to gray tuffaceous claystones and tuffs. Ledge at top of hill at $3 \mathrm{o}^{\prime}$ clock

is Ouaternary basalt.

Small dam on left. From this point the road swings generally west and rises in John Day Formation. Note landslide blocks of Quaternary basalt on right side of road for next 4.5 miles.

Fault crosses road, uplifting welded tuff of member $E$ on west. Fault scarp is visible to left, across meadow.

Road junction to Hay Creek Ranch--turn right toward Madras. Quaternary basalt crops out on skyline at $4 \mathrm{o}^{\prime} \mathrm{clock}$ with many landslide blocks below the rim. The cliffs at $120^{\prime}$ clock ware welded tuff of member G, John Day Formation.

Road junction--turn right toward Willowdale.

Stop 19. Examine outcrop of welded tuff of member G. Unit is densely welded, crystallized, and contains sparse lithophysae. Note abundant large soda-rich sanidine crystals. A major fault runs along the road, tilting the welded tuff sheet to the west. The low cliff on the west (left) side of the road is the basal ash-flow sheet of member H. This is overlain by Quaternary basalt, which at this point flowed down old channel of Hay Creek. Turn around and return to junction of Hay Creek Road.

Junction of Hay Creek Road--turn right.

Entrance to Hay Creek Ranch--take right hand fork of road.

Lithophysal welded tuff of member $E$ on both sides of road. Small landslide at 10 o'clock. $^{\prime}$

Brewer Reservoir. Fault runs along front of cliff on right, uplifting ledge of member $\mathrm{E}$.

Road junction--turn right. After turn, flat-topped hill at 1-2 o'clock is basal welded tuff of member $H$, overlying member G. Hill at 10 o'clock is welded tuff of member $G$.

Red outcrop at 2 o'clock is section of tuffaceous sediments of member F.

Road climbs to top of ash-flow sheet at base of member 6 . Here, welded tuff dips generally south but is folded into a series of broad, open folds. Outcrop across field at $11 \mathrm{o}^{\prime}$ clock is basal welded tuff of member I and cliff 
( 0.75$)$

103.60

(0.5n)

104.10

(0.65)

104.75

(0.65)

105.40

(1.40)

106.80

(0.45)

107.25

107.80

(0.35)

108.15

$(0.70)$

108.85

(1.35)

110.20

$(0.40)$

110.60

(1.55)

112.15

(1.50)

113.65

(0.90)

114.55

$(0.25)$

114.80

$116.15)$

$(0.25)$

116.40

(1.20)

117.60 at 3 o'clock is welded tuff of memher "', unlifted along a major fault. Far neak at 12 o'clock is Grav Butte in Smith Rock area.

Road junction. Stop 20. Tuff in road is grav, glassy, ash-flow tuff at has of memher $H$. Valk about 100 yards up road to left and examine basal ash-flow tuff of memher I. Here the unit is densely welded with a good vitrophyre at the base and a crystallized portion above.

Velded tuff of memher I crosses road.

Ledge on hoth sides of road is nuaternary basalt. Road climbs to top of basalt flow. This flow originated from a small shield volcano about a mile to the east and flowed down old stream channel towards Madras.

Road junction and cattle guard--turn left.

Small mound on right is shield volcano from which Ouaternary basalt flow was erupted. Grizzly Peak is at 12 o'clock.

Fdge of Ouaternary basalt. Here the unit overlies trachyandesite of member $R$, John Day Formation, which is exposed in quarry at $1 o^{\prime}$ clock. Note opposing dips of Grizzly Peak and Gray Butte in distance at 3 o'clock. Both underlain by rhvolite flow probably folded into broad syncline.

Welded tuff of member A, John Day Formation, in roadcut. This is the southernmost outcrop of this unit. To the south, old Clarno hills are onlapped by stratigraphically higher units of the John Day Formation.

Road junction--turn right toward Grizzly.

Road junction--turn right toward Lamonta and Prineville.

Fdge of Ouaternay hasalt flow exposed on right.

Road has climhed to top of flat-lying Madras Formation. This unit, mostly of Pliocene age, consists of fluviatile siltstones, sandstones and conglomerates with interlayered air-fall and ash-flow tuffs and basalt flows.

Small outcrop at 2 o'clock is rhyolite similar to that of Grizzly Peak, completely surrounded by rocks of Madras Formation.

Good view of Gray Butte at 10 o'clock. Low ridge just left of Gray But te is capped by same rhyolite flow. Low ridge at 9 o'clock is Yakima Basalt overlying tuffaceous sediments of John Day Formation. Low bench to right of Gray Butte underlain by Clarno-type flows dipping southeast.

Junction with U.S. Highway 26. Continue straight ahead on dirt road toward Culver. Ridge at 3 o'clock is basalt ash-flow tuff of member H. Note that strike of John Day is nearly E-W. Hills on right at 1-2 o'clock are also capped by welded tuff of member $\mathrm{H}$.

Road runs on surface of Madras Formation. Low hills at 3 o'clock are capped by welded tuff of member $\mathrm{H}$. Flat-topped butte at 11 o'clock is Haystack Butte, also capped by welded tuff of member $H$. Left of Haystack Butte this welded tuff laps onto Clarno-type rocks of Smith Rock.

Road junction--turn left.

Road junction--continue straight ahead.

Road junction--turn right. Good view of Grav Rutte on left after turn. 
Contact of Madras Formation and John Day Formation. John Day tuffaceous sediments of member $G$ form small hill surrounded by Madras Formation.

$(0.40)$

119.80

$(0.75)$

120.55

121.50

(0.65)

122.15

123.35

Good outcrop of Clarno Formation on right. Roadcuts are in Clarno Formation for next mile with John Day contact just above road on right.

Road junction--turn left.

Haystack Reservoir at $2 o^{\prime}$ clock. Top of ridge just beyond reservoir is welded tuff of member $\mathrm{H}$. Just below is a local welded tuff that pinches out to the right.

Welded tuff of member $H$ crosses road. Ridge at $10 \mathrm{o}^{\prime} \mathrm{clock}$ is lava flow from Juniper Butte.

\section{Road climbs to top of Madras Formation which surrounds the older rocks.} Butte at $11 \mathrm{o}^{\prime} \mathrm{clock}$ is Round Butte, a small shield volcano from which some of the basalt flows in the Madras Formation were erupted.

\section{Road junction--turn left.}

Junction U.S. Highway 97-turn left toward Redmond and Bend.

Juniper Butte, a rhyolite dome of John Day age at 1 o'clock.

Lava flow from Juniper Butte at 9 o'clock.

Welded tuff of member $H$, John Day Formation in roadcut.

Three Sisters volcanoes in High Cascades visible at $2 o^{\prime} c 1$ ock.

Approximate contact of Madras and John Day Formations. Haystack Butte at 9 $o^{\prime}$ clock is capped with welded tuff of member $\mathrm{H}$.

Gray Butte at $100^{\prime}$ clock, capped with rhyolite flow. Laharic breccias of Smith rock at 11 o'clock.

135.90

(2.65)

Road cuts with Madras basalt flow overlain by tuffaceous sediments.

\section{Madras basalt flow.}

Bridge across Crooked River Gorge.

Stop 21 (optiona1). Turn right to overlook for Crooked River. Gorge was cut in Madras Formation, then filled in with Quaternary basalt. Present gorge was cut through intracanyon basalt which is visible in canyon walls. Note columnar jointing in intracanyon basalt. Return to Highway 97 and turn right.

138.55

Tuff of Smith Rock exposed at 9 o'clock.

Basalt flow of Madras Formation in roadcut on left.

Terrebonne.

Tetherow Butte. This is a series of cinder cones marking vents from which some of the basalt flows of the Madras Formation were erupted. 
Redmond.

(5.75)

155.15

(0.85)

156.00

(0.25)

156.25

(1.55)

Junction Oregon 126--continue straight ahead on Highway 97.

Junction Oregon 126--continue straight ahead on Highway 97.

Old channel cut in Madras Formation and filled with Quaternary basalt.

Low hill on right is silicic dome of Forked Horn Butte, probably John Day age. Dome projects through Madras Formation.

157.80

Junction U.S. Highway 20--continue straight ahead.

Bend.

Road junction--turn right toward city center.

End of road log--corner of Franklin and Wall Streets. 


\section{INTRODUCTION}

This geologic field trip guide is a revision of "Roadside Geology, Santiam and McKenzie Pass Highways, oregon" (Taylor, 1968) with additions pertinent to geology of the Bend-Sisters area. Checkpoint mileages express cumulative distance from Central Oregon Community College in Bend, over a route which leads to Sisters, around the McKenzie Pass-Clear Lake-Santiam Pass highway loop, and back to Bend (see Index Map, Figure 1). Persons using this guide should anticipate one full day of at least $140 \mathrm{miles}$, and should check accessibility to McKenzie Sumit during winter, spring, and late fall.

\section{GENERAL REMARKS ABOUT CENTRAL CASCADE GEOLOGY}

A calc-alkalic volcanic arc has been intermittently active during the last $10-15 \mathrm{~m} . \mathrm{y}$. along the eastern part of the central Cascade Range in Oregon. The late Pleistocene record of this volcanic activity is well preserved on the crest of the High Cascades; the best exposed record of early pleistocene, Pliocene, and late Miocene Cascade volcanism is found in volcanic and volcaniclastic deposits on the east flank of the range and in the adjacent Deschutes Basin. In the following discussion, structural, stratigraphic, and magmatic features of the Western Cascade, High Cascade, and Deschutes Basin subprovinces are described and their interrelationships are briefly summarized.

\section{Central High Cascade Province}

The central High Cascade Range in Oregon is chiefly a Pleistocene volcanic platform of overlapping basalt and basaltic andesite lava flows whose aggregate thickness is generally unknown but probably exceeds 4,000 feet locally. This platform is elongate north-south and is $20-30$ miles wide. A typical volcano of the platform is a broad shield of lightcolored, vesicular basaltic andesite with a cinder cone core that has been invaded by plugs and radial dikes. Pleistocene examples exposed in cross-section by glacial erosion include Sphinx Butte south of Separation Creek canyon, Deer Butte north of Lost Creek canyon, and Bald Peter east of Jefferson Creek canyon; a perfectly preserved Holocene example is Belknap Crater on the McKenzie Pass summit. Some of the basaltic andesite volcanoes developed large composite structures reaching 10,000 feet elevation on a shield base 10 miles wide. Examples include The Husband, North Sister, Mount Washington, and Three Fingered Jack. In contrast, many volcanoes of the platform were active for only a brief time and produced small cinder cones with or without narrow lobes of lava. Holocene examples abound; they include Yapoah Cone, Twin Craters, and Sims Butte near McKenzie Pass, and Nash Crater, Lost Lake Cones, and Blue Lake Crater near Santiam Pass, Pleistocene cinder cones are no less abundant but they are not as well preserved. Examples of glaciated remnants of Pleistocene cones include Bluegrass Butte, Condon Butte, and Scott Mountain near McKenzie Pass and Maxwell Butte, Hoodoo Butte, and Cache Mountain near Santiam Pass.

A systematic temporal inhomogeneity exists within the High Cascade platform. Early Pleistocene lavas were predominantly high-alumina olivine tholeiites in vesicular, thin, widespread units, commonly with pronounced diktytaxitic textures. Later Pleistocene lavas were predominantly high-alumina basaltic andesites in thick, platy units, generally with pilotaxitic textures. The early basalts crop out in greater abundance and variety along the western and eastern margins of the platform and in the walls of deeply glaciated canyons; however, identical basalts do occur at higher levels. Later basaltic andesites cover most of the platform but they are also found at lower stratigraphic levels. Examples of early basalts are well exposed along the west margin of the platform at Cupola Rock in Lost Creek canyon, in cuts of Highway 126 north of Trailbridge Reservoir, and in the valley of Hackleman Creek west of Fish Lake. Early basalts along the east margin of the platform are widespread in the upper Metolius River valley and in the vicinity of Sisters.

A systematic spatial inhomogeneity also exists within the High Cascade platform. West of Bend, in the vicinity of South Sister, silicic volcanic rocks are interbedded with and rest upon the mafic platform rocks. A silicic highland of some 15 miles breadth was produced by the development of rhyolite, rhyodacite, and dacite domes surrounded by andesite, dacite, and rhyodacite lavas and ash-flow tuffs. Most of this highland is mantled by mafic cinder cones and lavas of the Triangle Hill group and by composite volcanoes such as Broken Top. Examples of interbedded andesites, dacites, and rhyodacite lavas are common in upper Squaw Creek and Tumalo Creek canyons. Two units of black andesitic ash-flow tuff (Century Drive Tuff and Shevlin Park Tuff) and one unit of pink, devitrified, dacitic ash-flow tuff (Desert Spring Tuff) were erupted from the highland and are well exposed west of Bend. Two rhyodacite ash-flow tuffs (Tumalo Tuff and Lava Island Tuff) and one extensive lapiliifall pumice deposit (Bend Pumice) of High Cascade origin are also exposed near Bend but were probably erupted from a vent south of the silicic highland. South Sister volcano is chiefly andesite with minor dacite and rhyodacite. Broken Top (east of South Sister) is basaltic andesite with minor interbedded dacite and rhyodacite lavas and small-volume ash-flow tuffs. Middle Sister (north of South Sister) is basalt with minor basaltic andesite, andesite, dacite, and rhyodacite. South Sister and nearby volcanoes are relatively late products of 1 ong-continued, compositionally diverse, and localized silicic magma- 


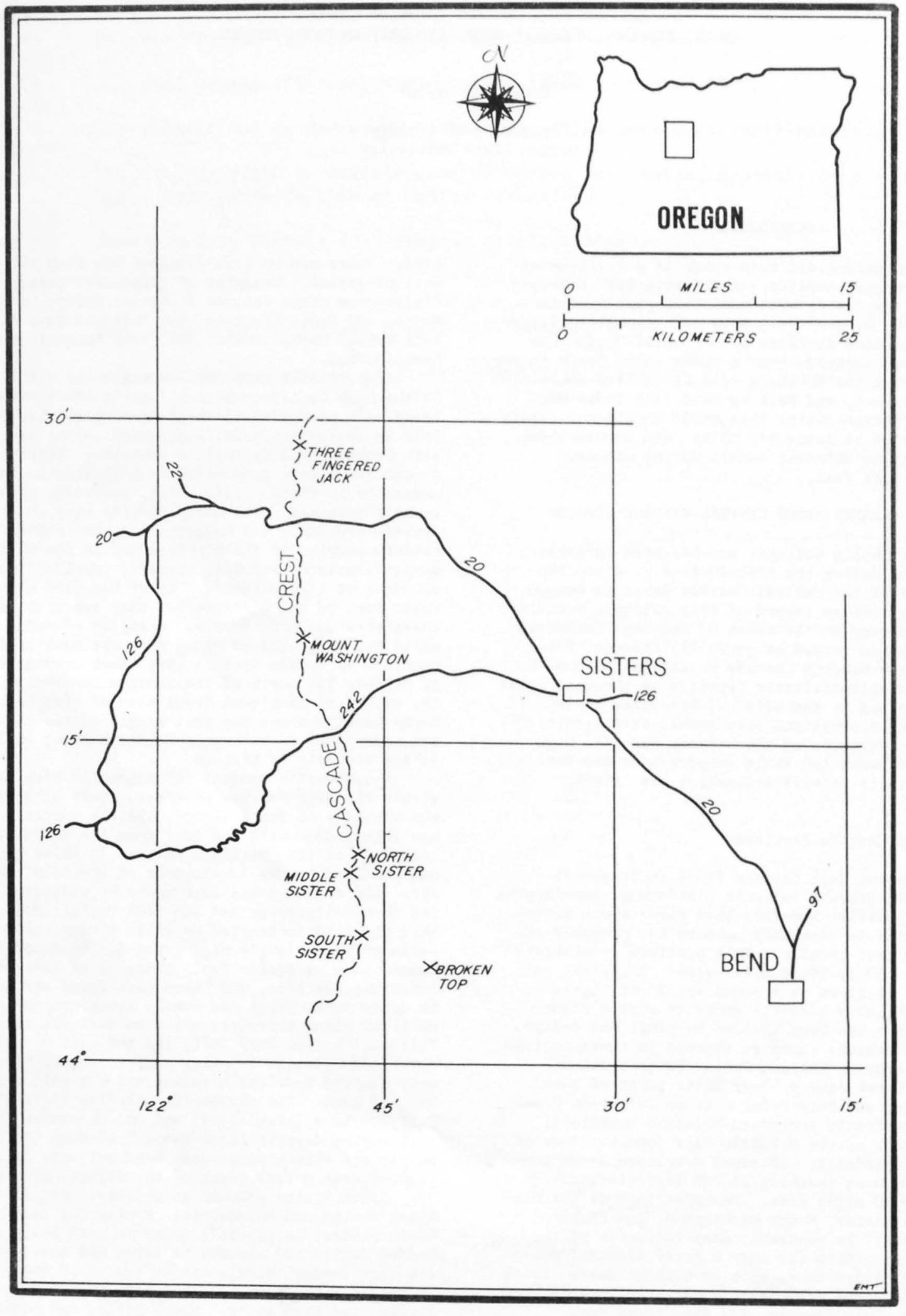

FiguRE 1. INDEX MAP, ROADSIDE GEOLOGY, BEND, Sisters, McKENZIE PASS, AND SANTIAM PASS. 
tism.

In summary, the central High Cascade Range is not the simple Pliocene-Pleistocene belt of andesite volcanoes commonly depicted in geology textbooks; instead, it is a broad pleistocene platform of mafic composition in which open-textured basaltic lavas were at first predominant, then became subordinate to basaltic andesite. Silicic magma has invaded this platform throughout its development but only in isolated regions.

\section{Deschutes Basin Province}

The eastern margin of the central High Cascade platform is marked by a very irregular contact with the late Miocene and Pliocene Deschutes Formation. Early platform intracanyon lavas extend as much as 5 miles east of the Cascade foothills and isolated pleistocene volcanoes of basalt and basaltic andesite rest on Pliocene rocks of the Deschutes Basin. Examples of High Cascade intracanyon lavas occur in lower Metolius River canyon, Deep Canyon, and near Squaw Creek, Bull Flat, and Tumalo Creek between Sisters and Bend. Isolated volcanoes of High Cascade affinity include Squaw Back Ridge, Long Butte, and Pilot Butte and Awbrey Butte near Bend.

The Deschutes Formation contains stream-deposited silt, sand, and gravel, andesitic-to-rhyodacitic ashflow and ash-fall tuffs, and interbedded basalt flows. The basaltic lavas were erupted from cinder cones and fissure vents within the Deschutes Basin but the epiclastic and volcaniclastic rocks were chiefly of Cascade provenance. Close to the Cascades, the formation becomes thicker, basaltic andesite lavas predominate, and the volcaniclastic rocks become discontinuous interbeds. Indicators of transport direction within the volcaniclastic sediments point eastward. Deschutes Formation source volcanoes were coincident with, or not far removed from the High Cascade axis. One deeply dissected remnant of an andesitic Deschutes Formation source volcano is located at the bend of Metolius River, 12 miles east of Mount Jefferson.

Strata of the Deschutes Formation between Warm Springs and Bend are generally flatlying except where they are offset by north-northwest-trending normal faults of small displacement. These faults are part of the Brothers-Sisters Fault Zone and are best exposed in cross-section along cuts of Highway 126 in Deep Canyon east of Sisters. The Deschutes Formation is unconformably underlain by folded and faulted basalts of the mid-Miocene Columbia River Group on the north and by silicic domes, lavas, and tuffaceous rocks on the south, variously ascribed to Clarno and John Day Formations of middle Tertiary age.

Parts of the High Cascade - Deschutes Formation contact are fault controlled. This is especially obvious at the west base of the Green Ridge escarpment, a 20-mile-long north-south fault block in which upper Deschutes Formation rocks stand 2,000 feet above the east edge of the High Cascade platform. $\mathrm{K}-\mathrm{Ar}$ ages of rocks on the crest of Green Ridge and of lavas emplaced against the base of the scarp indicate that faulting occurred during the interval 2.5 to 4.5 m.y. ago (Armstrong and others, 1975). A closely related but much less spectacular feature is the Tumalo Fault between Sisters and Bend. The Tumalo Fault can be traced without interruption for 15 miles; north and south segments extend its length another 10 miles. Parts of the Tumalo Fault were reactivated during the Pleistocene.

Green Ridge probably marks the east flank of a prominent Pliocene volcanic complex. North and south of Green Ridge the trace of a major fault is obscure; isolated hills of Deschutes Formation are surrounded by lavas of the platform and a previously existing fault-controlled topography appears to have been extensively eroded and almost completely buried.

A correct interpretation of the east-margin fault system is of great significance in understanding High Cascade and Deschutes Basin geology. My interpretation can be summarized as follows:

1. Deschutes Formation basaltic andesite lavas, andesite lavas, and ash-flow tuffs were derived from volcanoes near the present High Cascade axis and flowed eastward into the Deschutes Basin more than $4.5 \mathrm{~m} . \mathrm{y}$. ago. Rock units deposited by this process have been traced from Green Ridge to the Deschutes River. They reveal a continuous, gentle eastward dip of only 1-2 degrees. Therefore, Green Ridge cannot represent a tilted-up fault block. It is, instead, a remnant of stable eastern Cascade foothills and its rocks still rest on an initial paleoslope.

2. The maximum age yet obtained by radiometric dating of central High Cascade platform rocks is $3.9 \mathrm{~m} . \mathrm{y}$. Therefore, Deschutes Formation rocks and source volcanoes must lie beneath the Cascade platform and displacement of the eastmargin fault system probably exceeds (and might greatly exceed) 3,000 feet.

3. If Green Ridge has not been displaced upward relative to the Deschutes Basin, the Cascade axis has been displaced downward. This presumably occurred about $4.5 \mathrm{~m} . \mathrm{y}$. ago, terminating deposition of Deschutes Formation rocks.

Is it possible that a whole range of Pliocene composite volcanoes foundered and was buried beneath the Pleistocene High Cascade platform? Such an interpretation is strongly suggested by available field evidence. With appropriate informality, this hypothetical assemblage of volcanic rocks might be called the "Plio-Cascades."

\section{East Margin of the Central Western Cascade Province}

Stratigraphic and structural relationships at the western margin of the central High Cascade platform are obscured by more extensive erosion, thicker alluvial cover, and more luxuriant vegetation than along the eastern margin. However, striking similarities are evident. Isolated Pleistocene volcanoes of basalt and basaltic andesite occur in the Western Cascades at least 20 miles west of the platform. Examples include Harter Mountain, a cinder cone and flow near Quartzville, and Battle Ax Mountain. Early High Cascade platform basalts occur as intracanyon lavas in the adjacent Western Cascades. Examples include diktytaxitic basalts of Foley Ridge in the canyon of McKenzie River and similar rocks in the canyon of North Santiam River.

Rocks of the Western Cascades adjacent to the central High Cascade platform are predominantly late Miocene and pliocene mafic lavas (Armstrong and others, 1975; Sutter, 1978) with subordinate ash-flow tuffs and silicic volcanic domes. These rocks have been included in the Sardine Formation by Peck and others (1964) but should be assigned to the Outerson Formation of Thayer (1937). They are equivalent in lithology and age to the Deschutes Formation. They are generally flat-lying except where they are offset by northwest-trending normal faults of small displacement. Although many units of the Outerson Formation were vented along the eastern edge of the Western Cascades, several andesitic ash-flow tuffs and one basaltic andesite ash-flow tuff appear to have moved westward from Plio-Cascade volcanoes. Examples of Outerson Formation rocks can be seen along the southto-north crestline of mountains which includes Fris- 
sel1 Point, Bunchgrass Mountain, Browder Ridge, Iron Mountain, Echo Mountain, Crescent Mountain, Three Pyramids, and Coffin Butte.

Outerson Formation rests with angular and/or erosional unconformity upon a complex and poorly exposed assemblage of moderately deformed, altered, silicic volcaniclastic rocks with subordinate lavas and intrusive bodies. These rocks are part of the Sardine Formation. Examples of pre-Outerson rocks are best seen west of the Frissell Point-Coffin Butte crestline in canyons tributary to McKenzie River and South, Middle, and North Santiam Rivers. Many of these rocks have been assigned $\mathrm{K}-\mathrm{Ar}$ ages between 14 and 20 m. y. by Sutter (1978).

Although field evidence is still inconclusive, it is likely that the eastern part of the central Western Cascades was displaced several thousand feet down on the east side of a north-south fault system during the interval 4 to $5 \mathrm{~m}$.y. ago. Outerson Formation rock units exceed 3,000 feet in thickness and are approximately horizontal in attitude along the Frissell Point - Coffin Butte crestline. In the east face of a 30-mile-long deeply eroded north-south escarpment, they "sky-out" over the younger High Cascade platform. A major fault has been found at the base of this escarpment in a few places. For example, in the vicinity of Belknap Hot Springs, rocks on the crestline west of the fault are $6.2 \mathrm{~m} . \mathrm{y}$. old; rocks of the same age east of the fault occur 2,000 feet lower (Armstrong and others, 1975). Throughout its length, this fault system has been obscured by glaciation of the escarpment and by lavas of the High Cascade platform deposited against the base of the escarpment. space. It is likely that such a structure, 20 miles wide, would subside along many fractures, chiefly trending north-south. Intragraben faults could have served as channelways for ascending magma. This might explain why volcanoes on the High Cascade plat. form commonly occur within long north-south alignments and why volcanoes adjacent to the platiform ten not to do so. The early flood of gas-rich diktytaxi. tic basalts might be related to unusually rapid ascent of magma during a time of relative crustal tension. Correspondingly, the later dominance of basaltic andesite might reflect a slower ascent and greater opportunity for evolution of magmas.

Considerable evidence now suggests that a broad calc-alkaline volcanic field consisting of Deschutes Formation, "Plio-Cascades," and Outerson Formation rocks covered the eastern half of the central Cascade Range during late Miocene and Pliocene time. If it is assumed that a subduction system was responsible for this volcanism, it might also be assumed that the subduction process became inactive or modified approximately $4.5 \mathrm{~m} \cdot \mathrm{y}$. ago. This might have led to relaxation of the crust, subsidence along the volcanic axis, less frequent ascent of andesite-dacite magmas from more restricted, residual reservoirs, and much increased outpouring of basaltic magma from relatively shallow levels, probably associated more with Basin and Range magmatism than with a subduction system. However, it is easy to propose models. Testing their validity will require years of intense effort on many fronts.

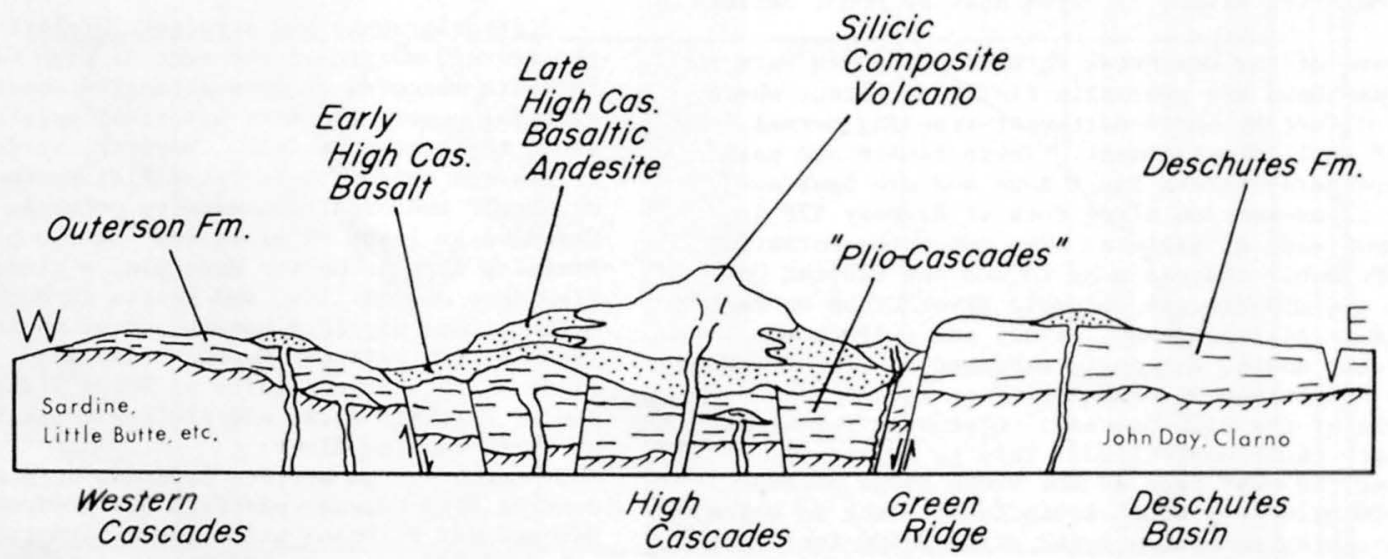

\section{FIgURE 2. DIAGRAMMATIC CROSS SECTION OF WESTERN CASCADE, HIGH CASCADE, AND DESCHUTES BASIN, OREGON.}

If it can be demonstrated that the High Cascade axis was displaced downward along marginal boundary faults relative to the Deschutes Basin and Western Cascades during the interval 3 to $4.5 \mathrm{~m} . \mathrm{y}$. ago, the High Cascade platform should be viewed as a Pleistocene fill within a Pliocene graben (Figure 2). On the basis of my own limited experience, I believe that this condition prevailed north at least as far as Mount Adams and south at least as far as Crater Lake, but was not necessarily continuous in time or 
ROADLOG FOR CENTRAL HIGH CASCADE GEOLOGY

BEND, SISTERS, MCKENZIE PASS, AND SANTIAM PASS, OREGON

\author{
Edward M. Taylor \\ Department of Geology \\ Oregon State University
}

MILES Start in Bend at corner of College Way and Newport Ave. in valley between Awbrey and Overturf Buttes. Proceed W. (out of town) on Newport Ave.-Shevlin Park Road. Roadcuts ahead are chiefly in lavas associated with cinder cones S.W. of Awbrey Butte. Awbrey is a shield volcano of diktytaxitic basalt that was probably last active during early Pleistocene. It rests upon tuffaceous sediments and lavas of the upper part of the Deschutes Formation. Four High Cascade ash-flow tuffs moved $\mathrm{W}$-to-E between Awbrey and Overturf Buttes and are now seen in scattered outcrops and in excavations, eastward to the Deschutes River. The ash-flow units are: (1) Desert Spring Tuff (black to gray, dacitic, poorly welded, large black pumice fragments), overlain by (2) Tumalo Tuff (orange, rhyodacitic, poorly welded), overlain by (3) Lava Island Tuff (cream to buff, rhyodacitic, completely devitrified, overlain by (4) Shevlin Park Tuff (black, andesitic, moderately welded and rather well sorted along ash-flow margins).

(1.2)

1.2 Right-hand curve. Note pumice quarries on left. They reveal welded Tumalo Tuff with a basal, thin white intralayer resting on Bend Pumice which has been extensively quarried for aggragate. Note a red Pleistocene cone of altered cinders on right-hand road side.

$(0.3)$

1.5

Left-hand curve. The last 0.5 -mile of roadway has followed the Tumalo Frult which behind this point extends 2 miles S.12E. and ahead of this point extends in a N.43W. direction for 1 mile, then continues N.38W. for 11 miles more. Rocks on the S.W. side of the fault have been displaced downward along each segment but not uniformly in amount. Roadway ahead leads over a narrow High Cascade mafic lava flow that moved S.W. to N.E. The lava flow and underlying Desert Spring Tuff, Bend Pumice, and Tumalo Tuff have all been displaced by the Tumalo Fault. The overlying Shevlin Park Tuff has not been displaced here but has been offset along the S.E. segment of the fault. Northwest of the lava, the surface is mantled by the gray nonwelded facies of the Shevlin Park Tuff.

$(1.2)$

2.7 Entrance to Shevlin Park. Recommended side trip. Follow park road to bridge over Tumalo Creek. Enroute, visit "Red Rock Gulch" on W. side of creek where Desert Spring Tuff is exposed. In roadcuts see bedded lapilli and ash of the basal member of Bend Pumice. On E. side of creek examine blocks of densely welded Shevlin Park Tuff with abundant black collapsed pumice fragments. Roadway leaving Shevlin Park follows a grade up W. side of Tumalo Creek canyon, cut into gray nonwelded Shevlin Park Tuff.

$(0.3)$

3.0 Top of grade; secondary road west. Recommended side trip. Follow secondary road $1 / 8$ mile $W$. Then drive or hike $1 / 4$ mile $N$ to a SW-NE gully in which is exposed the only outcrop of Lava Island Tuff that will be encountered on this field trip. Tuff has been intensely devitrified by vapor-phase alteration. 


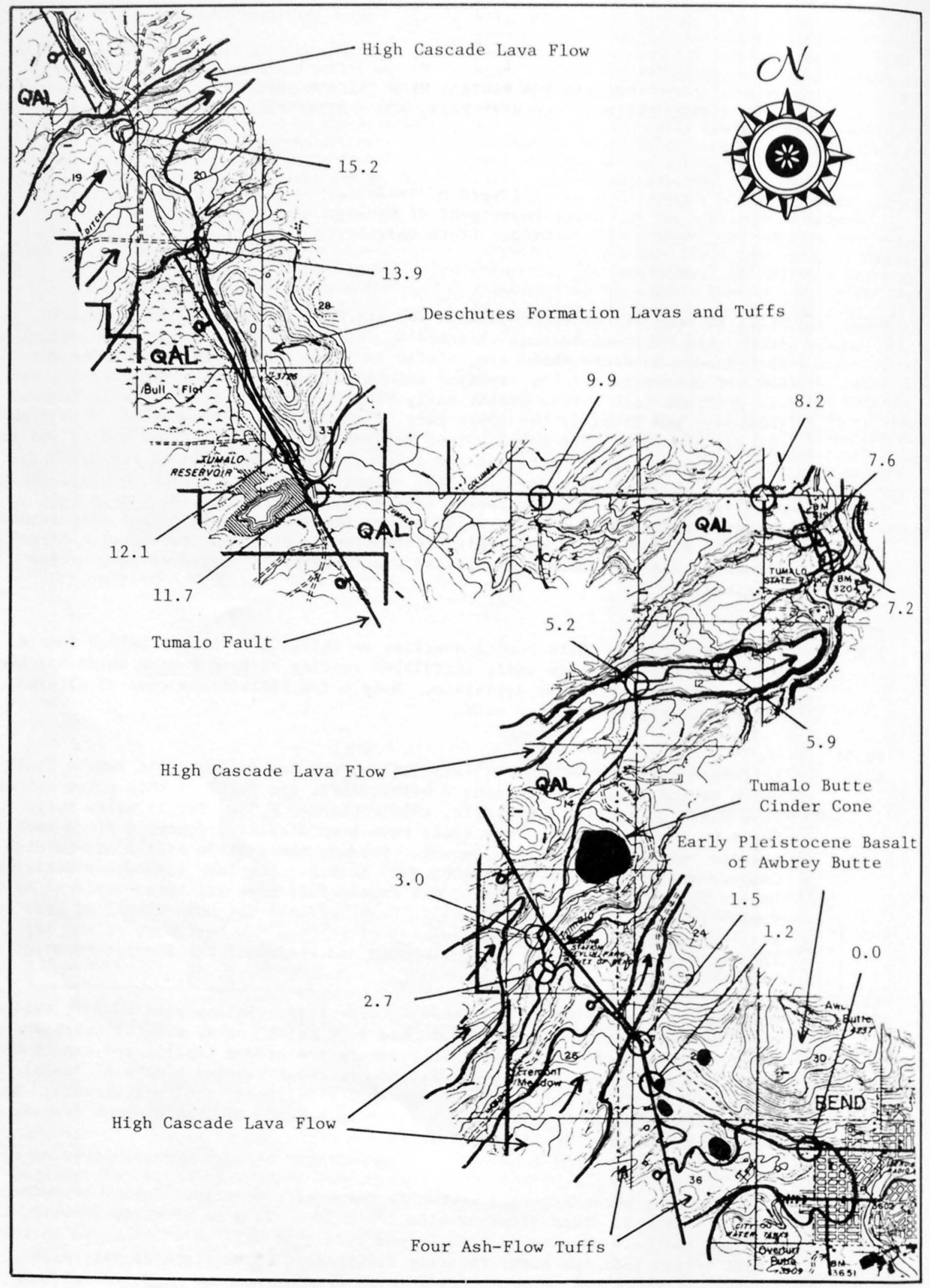

FIGURE 3. GEOLOGIC SKETCH MAP FROM MILE 0.0 TO MILE 16.6 
Roadway ahead passes $W$. of Tumalo Butte cinder cone which is older than the ash-flow tuff units. Roadcuts on N.W. flank of cone expose fine-grained marginal facies of Shevlin Park Tuff. Level terrain N. of Tumalo Butte is underlain by Pleistocene gravel deposits which occur stratigraphically between Tumalo and Shevlin Park Tuffs and have been extensively quarried for construction aggregate.

(2.2)

5.2

(0.7)

5.9

(1.3)

7.2

(0.4)

7.6

$(0.6)$

8.2

(1.7)

9.9

(1.8)

11.7 End of Tumalo Reservoir Road; turn right and cross bridge over outlet stream from Upper Tumalo Reservoir. Desert Spring Tuff forms S. bridge abutment; Deschutes Formation lavas are exposed along the $\mathrm{N}$. bank of the stream. This road follows the Tumalo Fault for the next 7 miles.

Sharp turn right. Roadway for next mile is on top of a High Cascade mafic lava flow which moved W. to E. Lava is overlain by Pleistocene gravels.

Left turn leading to N.E. downgrade, N. margin of lava flow. Roadcuts on right expose basal contact of lava resting on red, oxidized soil that developed upon Tumalo Tuff. Nonwelded, pink upper zone of Tumalo Tuff has been removed by erosion from lowlands to the N., revealing bedrock of orange, welded Tumalo Tuff between patches of Pleistocene gravel.

Junction of Johnson Road and Tumalo Market Road. Desert Spring Tuff is exposed in vicinity of the junction and rests upon Deschutes Formation lavas. Turn left onto Tumalo Market Road.

STOP NO. 1: Broad shoulder on left side of road opposite orange-colored roadcut. Examine vertical section through Desert Spring Tuff. From creek bed to road level: Partly collapsed black pumice fragments in pink, devitrified, welded matrix are concentrated at base, but nearly absent above. From road level to top of unit: Hydrated, orange and yellow, poorly welded matrix with abundant fresh, noncollapsed pumice fragments. Alluvial gravels on tuff are overlain by Bend Pumice. Exposed in quarry a few 100-feet W: Bend Pumice overlain by very poorly welded and nonwelded Tumalo Tuff which contains a finegrained white intralayer at its base. Exposed in roadcut and quarries a few 100-feet E: A NW-SE normal fault which dropped the section about 12 feet on the N.E. side. Bedded pumice deposits are exposed at roadway curve; they belong to the basal member of Bend Pumice and consist of ash-fall and reworked pumice ash and lapilli.

Turn left onto Tumalo Reservoir Road; proceed west. Pleistocene alluvial gravels mantle the nearby terrain. Quarries intermittently visible to the north have been excavated wherever the overburden of alluvium and Tumalo Tuff is sufficiently thin to permit extraction of Bend Pumice.

Tyler Road. Recommended side trip to examine welded facies of Tumalo Tuff. Follow Tyler Road 0.3-mile S., stop at base of grade; outcrops are N.E. of the road. This was near to the $N$. margin of the Tumalo ash flow. Pumice fragments as large as 1 foot contain cores of the only fresh, white, nonhydrated glass to be found in this unit. Along roadway ahead, alluvial gravels give way to scattered outcrops of Deschutes Formation mafic lavas as the Tumalo Fault is approached.
$(0.4)$

12.1

STOP NO. 2: Examine fine grained marginal facies of andesitic Shevlin Park Tuff exposed along N.E. side of road. Bull Flat (W. of the road) is underlain 
by Desert Spring Tuff, Bend Pumice, Tumalo Tuff, Shevlin Park Tuff, and alluvium deposited on the down-dropped side of the Tumalo Fault. Reactivation of the fault S.E. of Upper Tumalo Reservoir has displaced the tuff units and alluvial gravels.

$(1.8)$

13.9

Southeast abutment of Tumalo Dam. Roadcut exposes an oxidized and devitrified andesitic welded tuff of the upper part of the Deschutes Formation, interbedded here between Pliocene mafic lavas. This tuff has been traced more than 16 miles N. and N.E. into the Deschutes Basin. The N. abutment of the dam consists of an open-textured early High Cascade basaltic andesite flow that followed a stream channel through a gap in the fault scarp. The dam was part of a WPA project in which Bull Flat was to become a reservoir to store water brought by a flume system from the Deschutes River. For rather obvious geologic reasons, filling the reservoir was found to be impossible. The roadway ahead crosses over the High Cascade lava flow. This flow is underlain by Desert Spring Tuff, overlain by Shevlin Park Tuff, and has not been displaced by the Tumalo Fault.

$(1.3)$

$(1.4)$

16.6

(1.2)

17.8

(1.1)

18.9

(1.1)

20.0

(0.5)

20.5

(4. 4)

24.9

(0.7)

25.6

Road begins downgrade on $\mathrm{N}$. margin of High Cascade lava flow. This is an excellent point from which to view (S. to N.) Three Sisters, Black Crater, and Mount Washington on Cascade skyline with Triangle Hill group of cinder cones and lavas in middle distance covering the steep eastern slope of an older silicic volcanic highland. Prominent hills N. of Triangle Hill are Three Creek and Melvin Buttes - members of a group of four Pleistocene rhyolite domes. Roadway ahead follows the Tumalo Fault along which Deschutes Formation mafic lavas are exposed on the N.E. side and Desert Spring Tuff is exposed in scattered outcrops on the S.W. side.

Boundary between geologic sketch maps, Figures 3 and 4 .

Hill on the $W$. side of the road is the E. terminus of a High Cascade basaltic andesite lava flow. Deschutes Formation lavas crop out on the Tumalo Fault escarpment on the $E$. side of the road.

Old Plainview School site. Turn left and follow Gist Road to intersection with Highway 20. In this area alluvium mantles Desert Spring Tuff to the S.E. and an early High Cascade basalt porphyry lava to the N.W., both of which spread broadly to the N.E. and are intracanyon to the Deschutes Formation.

Intersection of Gist Road with Highway 20. Turn left on 20 toward Sisters.

Highway curves left around roadcuts in Deschutes Formation lavas. From here to Sisters, Pleistocene alluvium and inconspicuous outcrops of Pliocene mafic lavas are common.

Junction Highways 20 and 126. Proceed W. through Sisters. Sisters is built on Pleistocene alluvium, most of which has been deposited by Squaw Creek. The alluvium is underlain in this area by widespread High Cascade diktytaxitic basalt flows.

Junction Highways 20 and 242. Follow 242 W. toward McKenzie Pass. Excellent view of Three Sisters volcanoes on S.W. skyline. 


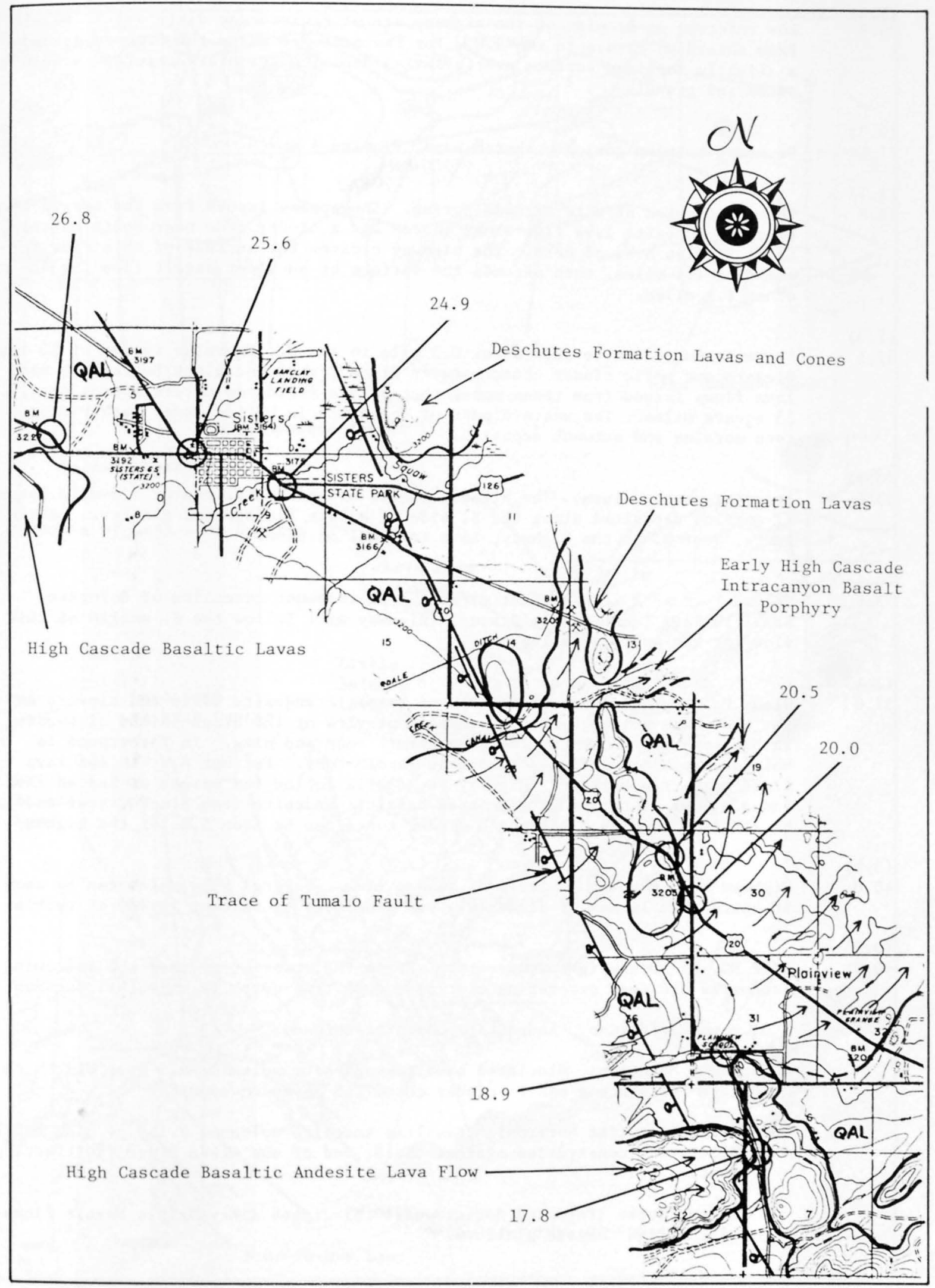

FIGURE 4. GEOLOGIC SKETCH MAP FROM MILE 16.6 TO MILE 27.1 

from shield volcanoes to the S.W. For the next 2.5 miles the highway ascends a slightly inclined surface over alluvial deposits which are chiefly outwash sands and gravels.

$(0.3)$

Boundary between geologic sketch maps, Figures 4 and 5 .

Left-hand curve at site of Cold Spring. The spring issues from the margin of a basaltic andesite lava flow whose source was a cinder cone near South Matthieu Lake, 9 miles S.W. of here. The highway crosses the surface of this flow for the next 1.1 miles, then ascends the surface of an older basalt flow for another 1.1 miles.

Fourmile Butte can be seen about 0.5 mile to the $\mathrm{N}$. Fourmile is one of 10 late Pleistocene mafic cinder cones between Black Crater and Black Butte. So many lava flows issued from these cones that a lava field now covers approximately 25 square miles. The western part of the field is buried under late Pleistocene moraine and outwash deposits.

(3).

Secondary road N. This point marks the easternmost extension of Holocene basaltic lava from Belknap Crater. Highway will follow the S. margin of this flow for the next 3.2 miles. al moraine deposited along the $\mathrm{S}$. side of a late Pleistocene glacier. Little Butte, just $\mathrm{N}$. of the highway, is a terminal moraine.

Windy Point. Glaciated promontory of basaltic andesite lavas and cinders at the N.W. base of Black Crater. Excellent view of the broad shield of Mount Washington surmounted by glaciated summit cone and plug. In foreground is Holocene basaltic andesite lava from Yapoah Cone. Farther N.W. is the lava field of Little Belknap. Highway ahead will follow the margin of Yapoah lava for 3 miles. Outcrops of glaciated basaltic andesite from Black Crater and basalt from smaller Pleistocene cinder cones can be seen S.E. of the highway.

Highway cuts through E. levee of Yapoah flow. Several flow units can be seen in which thin lenses of dense lava are separated by thicker layers of rubble.

STOP NO. 3: Dee Wright Observatory. From the observatory roof the following landmarks are seen proceeding clockwise from true north in azimuthal degrees.

0 Mount Jefferson: Andesitic composite volcano.

7 Cache Mountain: Glaciated basaltic andesite volcano, $0.9 \mathrm{~m} . \mathrm{y}$. old, with late Pleistocene basalt cinder cones and lavas on summit.

11 Bald Peter (far horizon): Basaltic andesite volcano, $2.1 \mathrm{~m} . \mathrm{y}$. old, deeply glaciated, constructed against the $\mathrm{N}$. end of the Green Ridge fault escarpment.

20 Dugout Butte (forested foreground): Glaciated diktytaxitic basalt flows of the High Cascade platform. 


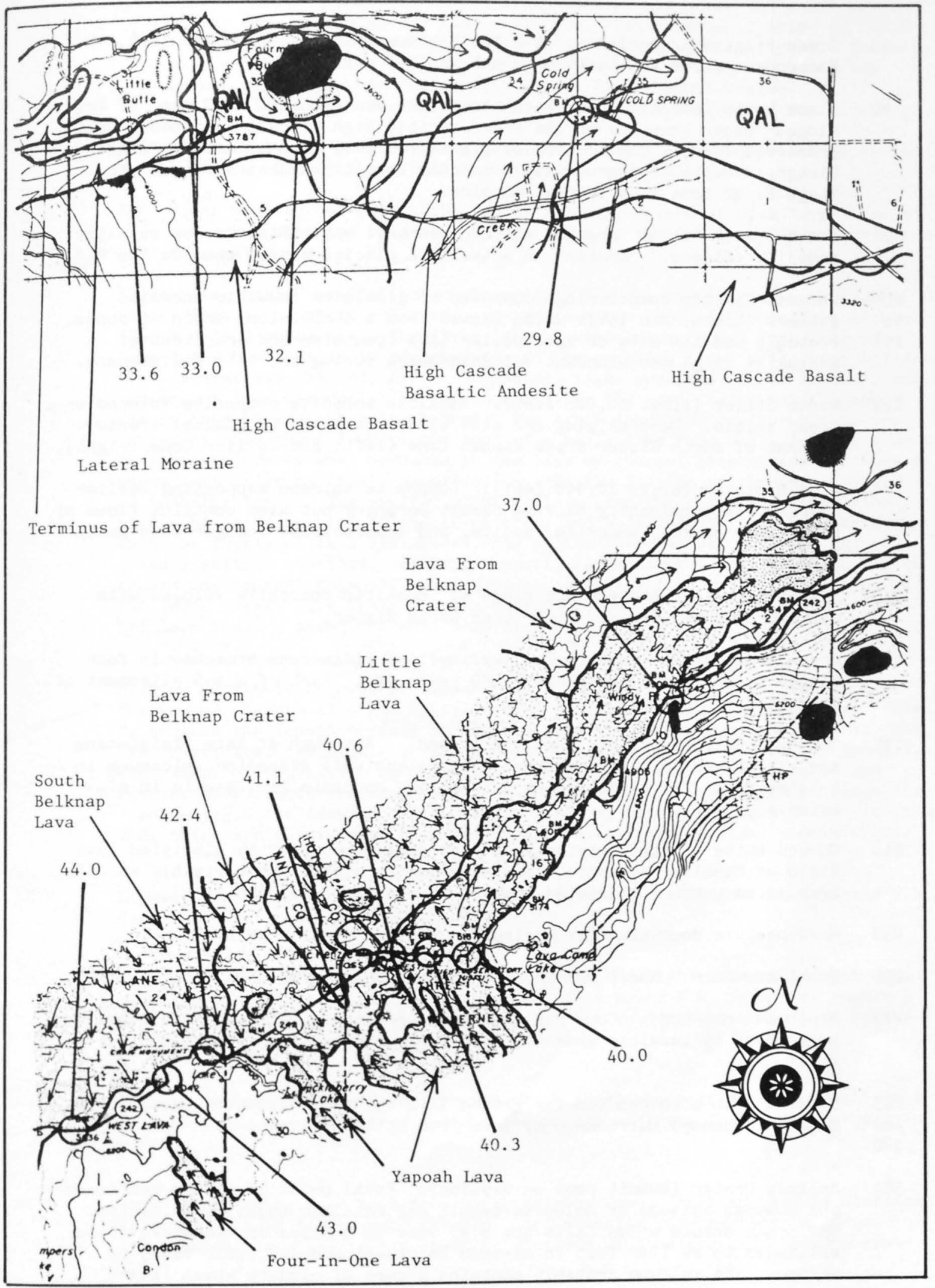

FIGURE 5. GEOLOGIC SKETCH MAP FROM MILE 27.1 TO MILE 34.5 AND FROM MILE 34.5 TO MILE 44.6 
Green Ridge (far horizon): N-S fault block mountain, 20 miles long. Escarpment faces $W$. Lavas on crest are 5-6 m.y. old.

Black Butte (background): Basaltic cinder cone located at $S$. end of Green Ridge. Older than any of the other visible High Cascade volcanoes; well preserved form is due to lack of glaciation east of the Cascade Range. Bluegrass Butte (foreground): Glaciated basaltic andesite cinder cone. Ridge $E$. of cone is a lateral moraine.

Black Crater (fills most of eastern sector): Late Pleistocene basaltic andesite volcano. "Crater" is actually a glacial cirque open to the N.E.

105 Unnamed Cascade summit ridge composed of glaciated basaltic andesite to cinders, bombs, and lavas which issued from a 5-mile-long chain of cones.

155 Probably was the site of spectacular lava fountains and eruptions of unusually large and abundant volcanic bombs during the late Pleistocene.

168 North Sister (elev. 10,085 feet). Basaltic andesite composite volcano on a broad shield. Central plug and dike systems exposed by glacial erosion. At base of North Sister stand Yapoah Cone (left) and Collier Cone ( $r i g h t$ ).

174 Middle Sister (elev. 10,045 feet): Composite volcano supporting Collier Glacier. Predominantly olivine basalt porphyry but also contains flows of basaltic andesite, andesite, dacite, and rhyodacite. Younger than North Sister.

178 Summit of Little Brother and ridge W: Basaltic composite volcano with exposed plug and dikes. Older than North Sister.

188 Four-in-One cinder cone (below skyline): A ridge-cone breached in four places by andesite lava flows, 2600 years ago. Part of a $\mathrm{N}-\mathrm{S}$ alignment of 19 vents.

197 The Husband (on skyline, partly obscured): Although of late Pleistocene age, it is one of the oldest and most extensively dissected volcanoes in this region. The exposed plug of basaltic andesite is 1/4-mile in diameter.

218 Condon Butte: Late Pleistocene cinder cone surrounded by glaciated lava field of basaltic andesite. Nested summit craters. Knob visible at left base is an unnamed glaciated dome of rhyodacitic obsidian.

Horsepasture Mountain (far horizon): Western Cascade peak.

Scott Mountain: Small summit cone on a broad glaciated basaltic shield.

South belknap Cone: Cone was formed and breached 1800 years ago, then surrounded by basaltic andesite lava from a nearby vent about 1500 years ago.

Unnamed twin steptoes (in foreground lava field): Glaciated basaltic andesite volcanoes surrounded by lava from Little Belknap.

309 Belknap Crater (summit cone on skyline): Focal point of a long-continued and complex episode of Holocene basalt and basaltic andesite volcanism. The broad shield which fills the N.W. view is 5 miles in diameter; it is estimated to be 1700 feet in maximum thickness and 1.3 cubic miles in volume. The volcano probably contains a core of cinders which inter- 
fingers with peripheral lavas and whose surface expression is the summit cone. Basaltic andesite issued from vents at the north and south bases of the cone approximately 1500 years ago. Lava poured 12 miles to the $W$. and ash was ejected from the northernmost of two summit craters. The main bulk of Belknap ash, which has been traced over an area exceeding 100 square miles, was ejected earlier from a larger south crater. Still earlier lavas were basaltic and moved eastward 7 miles from their vents.

321 Little Belknap: A subsidiary shield volcano, built 2900 years ago on the E. flank of the larger Belknap shield.

340 Mount Washington (elev. 7795 feet): Glaciated remnant of a large basaltic andesite composite volcano. Central plug is flanked by $\mathrm{N}-\mathrm{S}$ swarm of dikes in summit cone.

"Lava River Trail" east of the observatory: The observatory is located on a blocky flow of basaltic andesite, erupted from the base of Yapoah Cone between 2600 and 2900 years ago. The first lobe of Yapoah lava moved over this area toward the N.W. but as it advanced toward the opposing slope of Belknap Volcano, its movement was checked, arcuate pressure ridges appeared on its surface, and subsequent lava was deflected toward the N.E. The area just E. of the observatory then became the main channel. The trail leads the visitor across the center of this channel where the roof of a small lava tube collapsed and a host of vertical cracks were produced in the lava by thermal contraction and loss of gases just prior to final consolidation. On the E. side of the main channel is an imposing levee. The visitor might well imagine the channel in full flood, rising at least as high as the levee crest and spilling over the eastern flank. When the supply of lava diminished, the molten interior drained away and the channel surface subsided. Lacking support, large segments of the levee tipped toward the central channel, causing deep, irregular tension cracks to open in the levee crest. The trail affords a view of one of these cracks and of several lava tongues along the east base of the levee.

$(0.3)$

40.6

$(0.5)$

41.1

42.4

(0.6)

43.0

(1.0)

44.0

Highway curves in descent of Yapoah flow W. margin. Trees grow readily upon the younger Yapoah flow but sparsely upon the older Little Belknap flow. This is because the Yapoah surface is covered with blocks, interstitial scoria, and fine particles; the Little Belknap surface is much more coherent. In general, the extent of vegetation on Holocene lavas is governed more by climate and surface characteristics than by age of the lava. Where the highway leaves the Yapoah margin and crosses a pre-Belknap surface, notice the dark soil. It is 3 feet thick and consists of lapilli and ash chiefly from Belknap summit cone.

Highway passes over the crest of a Little Belknap lava tongue which poured S.E. down the older Belknap shield.

Craig Lake. Glacial striations can be seen on the light-colored bedrock marginal to Belknap lava. Late Pleistocene glaciers moved N.W. from here toward a valley that drained $W$. to McKenzie canyon. The entire valley has been buried beneath the Belknap shield.

Highway is straight and level for 0.6 miles ahead where it crosses an alluvial fill that has been deposited against the margin of lavas from South Belknap cone.

STOP NO. 4: Margin of lava from South Belknap Cone. Belknap lava is distinct from Yapoah lava in its more coherent, occasionally ropy surface on large, dismembered slabs and in its abundant clusters of fine-grained glomeropheno- 
crysts of plagioclase, olivine, and clinopyroxene. This lava was erupted 1800 years ago. To the $\mathrm{N}$. is an excellent view of $\mathrm{S}$. slope of Belknap volcano. Twin Craters cinder cone is visible to the W.; it was active 2600 years ago. Next 1.1 miles leads over glaciated lava from Condon Butte.

$(0.6)$

44.6

$(0.7)$

45.3

$(1.2)$

46.5

$(0.8)$

47.3

$(0.4)$

47.7

$(0.4)$

48.1

(3. 3)

51.4

$(2.1)$

53.5

Boundary between geologic sketch maps, Figures 5 and 6 .

Trail to Hand Lake. Hand Lake is dammed by lava from Twin Craters. Highway leads S. across Lake Valley, an area of low relief between lavas of Twin Craters to the $\mathrm{N}$. and Sims Butte to the S. Late Pleistocene glaciers moved S.W. over this valley on their way to the head of Lost Creek canyon. Several lobes of ice branched off through low divides to the W., excavating depressions in the bedrock lava. The depressions are now occupied by lakes such as Melakwa and Benson. Most of the valley floor is covered with reworked deposits of volcanic ash from Belknap Crater, Sims Butte, and Mount Mazama.

Three Sisters view point. North Sister is a basaltic andesite composite volcano on a shield base. Middle and South Sisters are younger, do not rest upon shields, and are much more diverse in composition. Forested slope in E. foreground consists of glaciated basalt flows from Little Brother volcano.

Right-hand curve followed by $0.4 \mathrm{miles}$ of straight level highway over reworked ash and lapilli from Sims Butte cinder cone, 0.5 miles S.E. The alluvium was deposited in a depression along the $\mathrm{N}$. margin of Sims Butte lava. Sims Butte was active sometime during the interval 7,000 to 12,000 years ago, because Mazama ash occurs on Sims Butte lava and cinders from Sims Butte rest upon latest Pleistocene glacial drift. An 800-foot cone was built while short lava lobes spread N. and S., and ash and lapilli drifted N.E. Finally, a lava vent opened at the western base and a large sector of the cone was carried away.

Left-hand curve; highway crosses over the central part of the western lobe of basaltic andesite lava from Sims Butte. The lava issued from a vent 3000 feet E. of this point, spilled into Lost Creek canyon, and covered the floor of the canyon to a point 9 miles $W$. of here.

Parking area on left side of highway. High-standing margin of lava from Collier Cone can be seen a short distance to the $\mathrm{S}$. The next 3 miles of highway cuts and abrupt switchback turns present a seemingly endless succession of thin, slaggy flows of basaltic andesite that poured from Sims Butte down the walls of the Lost Creek glacial trough. Occasional views of South Sister and The Husband are encountered.

Hairpin curve to the right with parking area. Recommended side trip. Follow trail about 0.8 miles to Linton Lake. Trail crosses over several nested lava levees and the central lava gutter, each of distinct mineralogical and chemical composition, but all from Collier Cone. Collier Cone was active sometime between 500 and 2500 years ago. With respect to its variable composition, Collier Cone is similar to the much-studied Mexican volcano, Paricutin. The Collier lava dammed Linton Creek to form Linton Lake.

Parking area and trail to Proxy Falls. Recommended side trip. On the short trail to the falls is a view of the Deer Butte plug and associated cinder cone, enclosed within lavas of a shield volcano. As a result of intense glaciation on the $\mathrm{N}$. canyon wall, the entire butte is exposed in cross section. The trail 


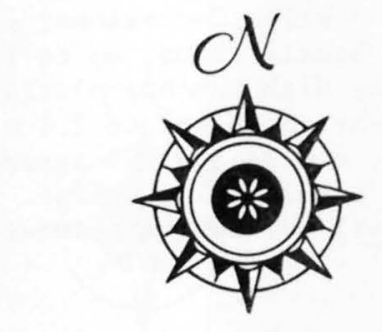

Lava From South Belknap

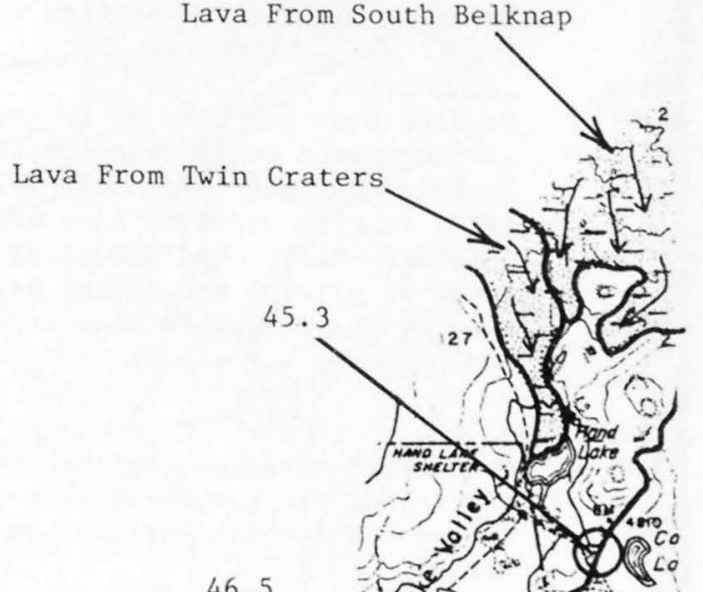

Early High

47.7

46.5

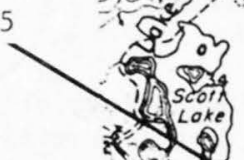

is.

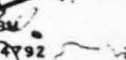

47.3
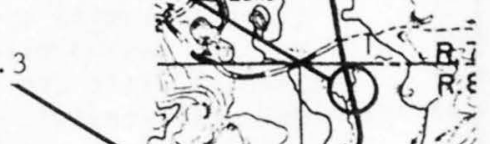

Cascade

Basalt

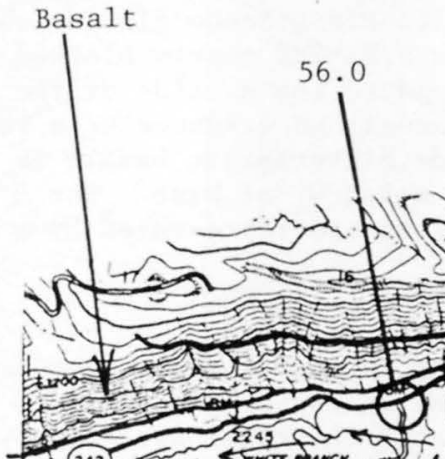

Lava From Deer Butte
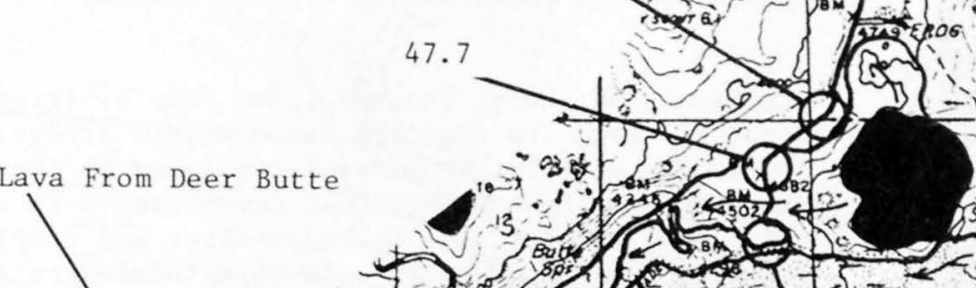

अर्ष
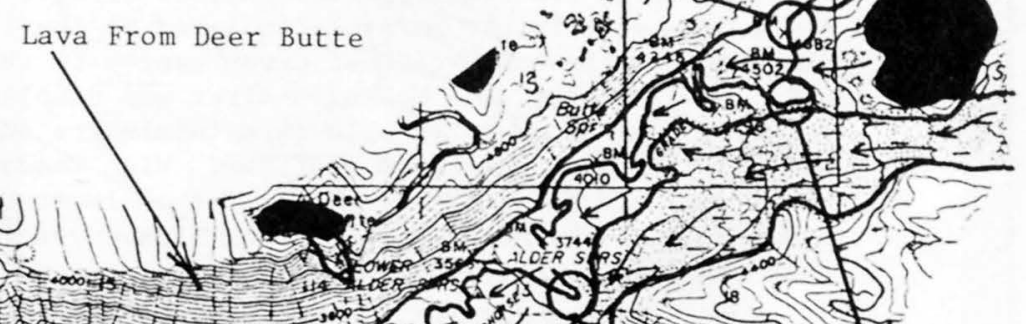
leads over the Collier flow, about 0.7 miles from its terminus. Many waterfalls spill down the $\mathrm{S}$. wall of the canyon; some are fed by springs from interbeds between lava flows in the cliffs, but the main Proxy Falls is that of a creek which drains a hanging valley, 800 feet above.

$(2.5)$

56.0

(1.9)

57.9

(0.9)

58.8

(3.6)

62.4

(1.0)

63.6

(1. 3)

64.9
Parking area and road S. to Youth Camp. For the next 3 miles, occasional views of the canyon walls reveal a sequence of diktytaxitic basalt flows, up to 1500 feet in combined thickness, which forms the base of the High Cascade platform. Flows in this vicinity have been dated at $3.9 \mathrm{~m} . \mathrm{y}$. (near the base) to $2.1 \mathrm{~m} . \mathrm{y}$. (near the top). Individual flows are thin, relatively coarse-grained aggregates of olivine and augite set in a porous matrix of tabular plagioclase. Many of the flows are separated by brick-red, baked soil horizons and interbeds of sand and gravel.

Boundary between geologic sketch maps, Figures 6 and 7 . During the last major glaciation the canyon at this point was so full of ice that a small lobe overtopped the lateral moraines on the N. rim and moved 2 miles down an adjacent valley.

Clear area followed by small bridge over White Branch Creek. Lost Creek and its tributaries appear and disappear in springs and sinks in the Sims lavas. For the next 3 miles all geologic features except Holocene lava and Pleistocene glacial drift are obscured by luxuriant forest. In the canyon walls High Cascade diktytaxitic basalt rests with erosional unconformity upon volcanic and volcaniclastic rocks of the Western Cascades, chiefly the Outerson Formation.

Junction of Highways 242 and 126. Turn N. (right) onto 126. Rest rooms, gasoline, and food are available at McKenzie Bridge, 2 miles $W$. Highway cuts $W$. and E. expose terminal moraines emplaced by the late Pleistocene glacier that emerged from the mouth of Lost Creek canyon to the S.E. and nearly blocked the McKenzie drainage. The McKenzie River was displaced to the $\mathrm{N}$. side of the valley but was apparently able to maintain its channel; no evidence of a related backfill has been found upstream. High Cascade diktytaxitic basalt is intracanyon to McKenzie River valley for at least 9 miles W. of here. For 5 miles down the McKenzie Valley, the intracanyon flows are represented by a medial ridge (Foley Ridge).

Road left to Belknap Hot Springs. One of three hot springs in this area aligned N-S and probably locallized by a fault zone which is partly buried by High Cascade lavas. Rimrock cliffs on the W. side of the river are composed of fine-grained basaltic andesite lavas resting upon a section of diktytaxitic basalts. Both units are erosional remnants of a much more extensive High Cascade sequence deposited on rocks of the Outerson Formation along the eastern edge of the Western Cascades.

Road to the right leads up Scott Creek. Recommended side trip. The High Cascade-Western Cascade boundary is located 2 miles up this road. Below the boundary is an assemblage of nonporphyritic platy basalts, porphyritic basalts, breccias, and tuffaceous interbeds which are cut in many places by $E-W$ normal faults and are generally inclined to the $S$. Above the boundary is a section of nearly horizontal palagonitic tuffs, basaltic pillows, dikes, and flows which are part of the early High Cascade diktytaxitic basalt sequence. Above the palagonitic tuffs is a series of thin-bedded, siliceous tuffs capped by a thick intracanyon basalt flow whose columnar joints, spiracles, and pipe vesicles are excellently exposed. Roadcuts and canyon walls along the next 10 miles of highway reveal mafic lavas and volcaniclastic rocks of the Western Cascades, 


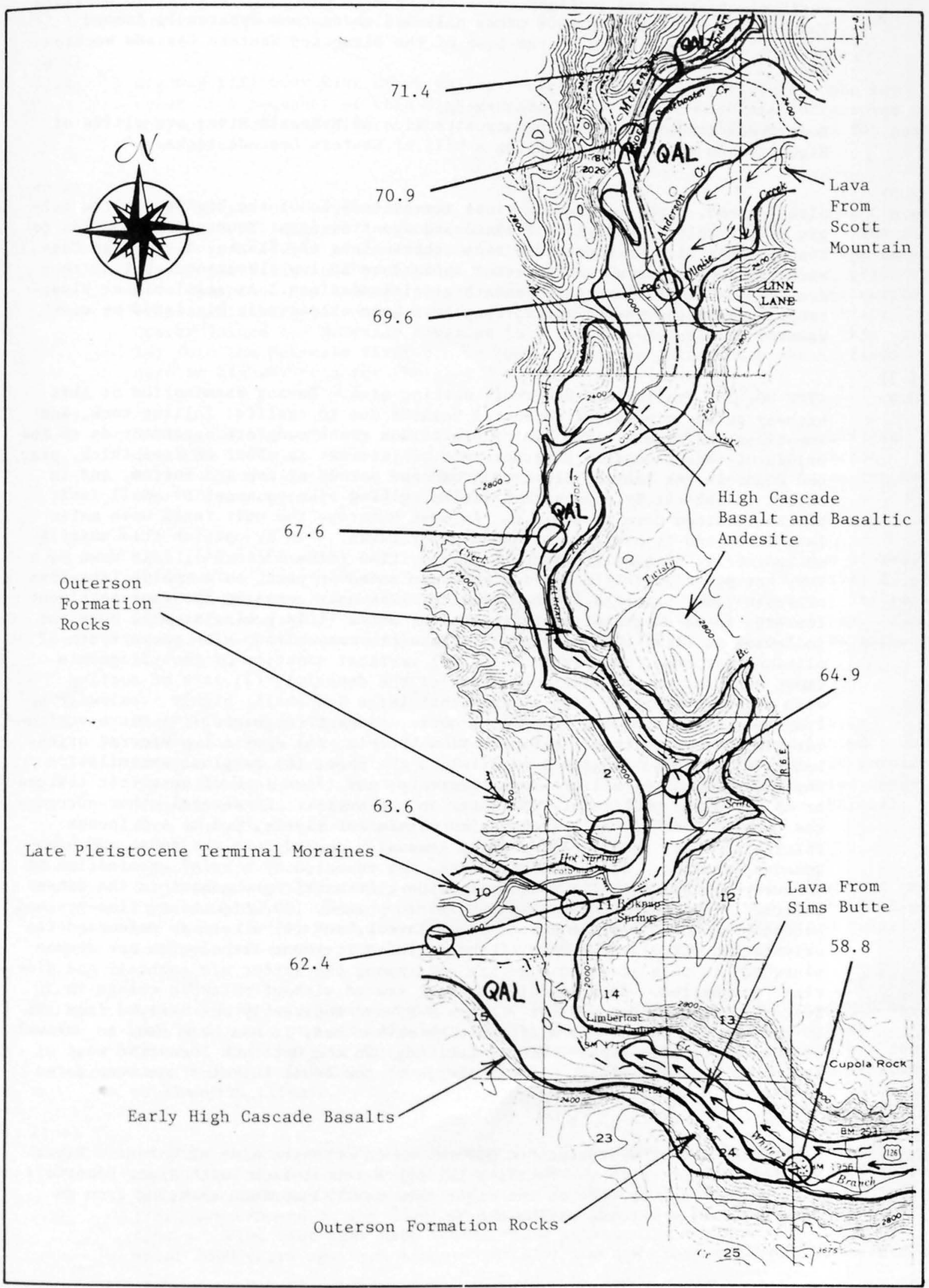

FIGURE 7. GEOLOGIC SKETCH MAP FROM MILE 57.9 TO MILE 72.3 
variously faulted and inclined, overlain by High Cascade diktytaxitic basalts. The High Cascade basalts were often pillowed where they apparently dammed streams and formed lakes at the base of the dissected Western Cascade escarpment.

(2.7)

67.6

(2.0)

69.6

(1.3)

70.9

Deer Creek Road, left. On the opposite side of McKenzie River are cliffs of High Cascade basalt flows capping a hill of Western Cascade rocks.

Ollalie Road, right. Forested slope immediately E. of the highway is the margin of a basalt flow of late Pleistocene age from Scott Mountain, 6.5 miles to the E. This flow is similar to many others along the flanks of the High Cascades in presenting a fresh, recent appearance at low elevations, but as they are traced higher, they pass beneath glacial moraines. At still higher elevations, near their source vents, they have been extensively glaciated or even removed by glacial erosion.

STOP NO. 5: Trailbridge Reservoir parking area. During examination of this highway cut be mindful of potential hazards due to traffic, falling rock, and impatient colleagues. Two geologists seldom reach complete agreement as to the origin of this deposit. The rock unit of interest is about 40 feet thick, gray and dense in the center, black to brown and porous at top and bottom, and is offset in the cut by four normal faults, giving rise to a set of small fault blocks inclined down to the N.E. In most outcrops the unit rests upon mafic lava flows and is overlain by mudflows or lavas. In my opinion this unit is an ignimbrite of basaltic andesite composition ( $\mathrm{SiO}_{2} 53$ to 54), laid down by a very hot pyroclastic flow. It might have moved in part, as a mobile lava-foam or froth-flow, prior to intense welding. The unit contains too many pertinent features to be adequately described here, but a field geologist will note the following at first observation: (1) Basaltic composition with phenocrysts of olivine, pyroxene, and plagioclase, (2) vertical zonation of rock fragments (most abundant in the lower one-third of the deposit), (3) lack of sorting with regard to size or density such that large and small, highly vesicular fragments are mixed with respect to dense, compact fragments, (4) micro-vesicular top and base without rubble or flow breccia, (5) distinct preferred orientation of elongate fragments parallel to the base, (6) marginal assimilation and discoloration of silicic rock fragments, and (7) a lack of eutaxitic texture or of any other particulate character in the matrix. In several other outcrops the basal 6 feet of the unit contains persistent layers, 0.5 to 4.0 inches thick with sharp interfaces, passing gradually upward into the dense and homogeneous interior. Additional features, not revealed by a brief examination of an outcrop, include: (1) Holocrystalline pilotaxitic groundmass in the dense interior, (2) lack of hydrous phenocrystic phases, (3) ubiquitous, fine-grained, secondary chabazite in the porous basal layers, and (4) a reverse paleomagnetic orientation throughout. Some of the included fragment lithologies are common elsewhere in this area and some are not; among the latter are gabbroic and dioritic porphyries. This deposit has been traced without noteable change in features, discontinuously for 7 miles $\mathrm{N}-\mathrm{S}$, and apparently was derived from the E. rather than the $W$. As a distinctive marker bed, it has been used to unravel structural complications (chiefly faulting) in the Outerson Formation west of the upper McKenzie River. A bulk sample of the dense interior has been dated by $\mathrm{K}-\mathrm{Ar}$ at $5.0 \mathrm{~m} . \mathrm{y}$.

$(0.5)$

71.4 Right-hand curve; hydroelectric powerhouse on opposite side of McKenzie River. Water is conducted to the facility through a tunnel from Smith River Reservoir 2 miles $W$. Highway cuts on the right show several springs emerging from an aquifer of High Cascade pillow basalt. 
$(0.5)$

72.8

75.2

75.9

$(1.1)$

77.0

(1.5)

$+78.5$

(1.7)

80.2

(0.5)

80.7

(1.4)

82.1

Highway fill over Kink Creek valley. Beginning of a long grade up onto the crest of a sequence of thin High Cascade basalt flows which are intracanyon to the upper McKenzie River. The flows are well exposed in highway cuts for the next mile.

South margin of Holocene basalt flow. Lava from the N. base of Belknap Crater, 8 miles S.E., entered the McKenzie River canyon here, 1500 years ago. The flow poured in a double cascade down cliffs to the $W$. and spread out upon the canyon floor, extending another 2 miles downstream. During the Pleistocene, prior to development of the Belknap shield volcano and related lava fields, the entire western discharge of meltwater from ice between Mount Washington and Black Crater joined the McKenzie River at this point. Lava flowed through this valley into the McKenzie River canyon many times; the intracanyon basalt flows seen in highway cuts for the last 2 miles were so derived.

Series of highway cuts and cliffs to the right expose many thin lava flows dated at $1.2 \mathrm{~m} . \mathrm{y}$. They are probably a part of a large early High Cascade basaltic andesite shield volcano whose central plug and flanking lavas can be seen in the opposite wall of McKenzie River canyon, 1 mile $W$.

Sahalie Falls parking lot. Recommended scenic stop. Two thick flows of basaltic andesite lava from the Sand Mountain chain of cinder cones ( 3.3 miles E. of here) moved into McKenzie River canyon in this area, 3000 years ago. The terminus of the first flow is marked by Koosah Falls, 0.4 miles downstream. The second flow, whose terminus is marked by Sahalie Falls, is seen in the highway cut ahead.

Road on right to Clear Lake. Clear Lake is $1.5 \mathrm{miles}$ long, fed by large springs, and is more than 120 feet deep in places. It was formed behind a dam of lava which issued from a cinder cone S. of Sand Mountain and poured across the McKenzie River. Rising waters inundated a standing forest; several dozen snags are still rooted on the lake floor. Wood from the snags and charcoal from beneath the east-shore lavas are both $3000 \mathrm{C}-14$ years old.

South margin of Holocene lava and outlet channel from Fish Lake. The lava came from early vents of the Sand Mountain chain of cinder cones and dammed Hackleman Creek to form Fish Lake 3800 years ago. The lava is basaltic and relatively thin with smooth ropy surfaces; tree molds are common.

Road to Fish Lake Campground on left. Highway crosses from 3800-year-old basaltic flow to younger, thicker, blocky basaltic andesite flow from Nash Crater. Fish Lake is dry during each summer, but this apparently was not the case before the $1900^{\prime} \mathrm{s}$. Lava-dammed lakes are sometimes sensitive indicators of changing climate.

Junction of Highway 126 with Highway 20. Turn right (east) on 20. The junction area has been invaded by Holocene basalt flows on three separate occasions: (1) 3800 years ago from a group of cones between Nash Crater and Sand Mountain (lava now exposed on the floor of Lava Lake, 0.5 miles N.), (2) subsequently from a buried vent near Nash Crater (lava surrounding the junction), and (3) about 3000 years ago from exposed vents at the N.W. base of Nash Crater (blocky 


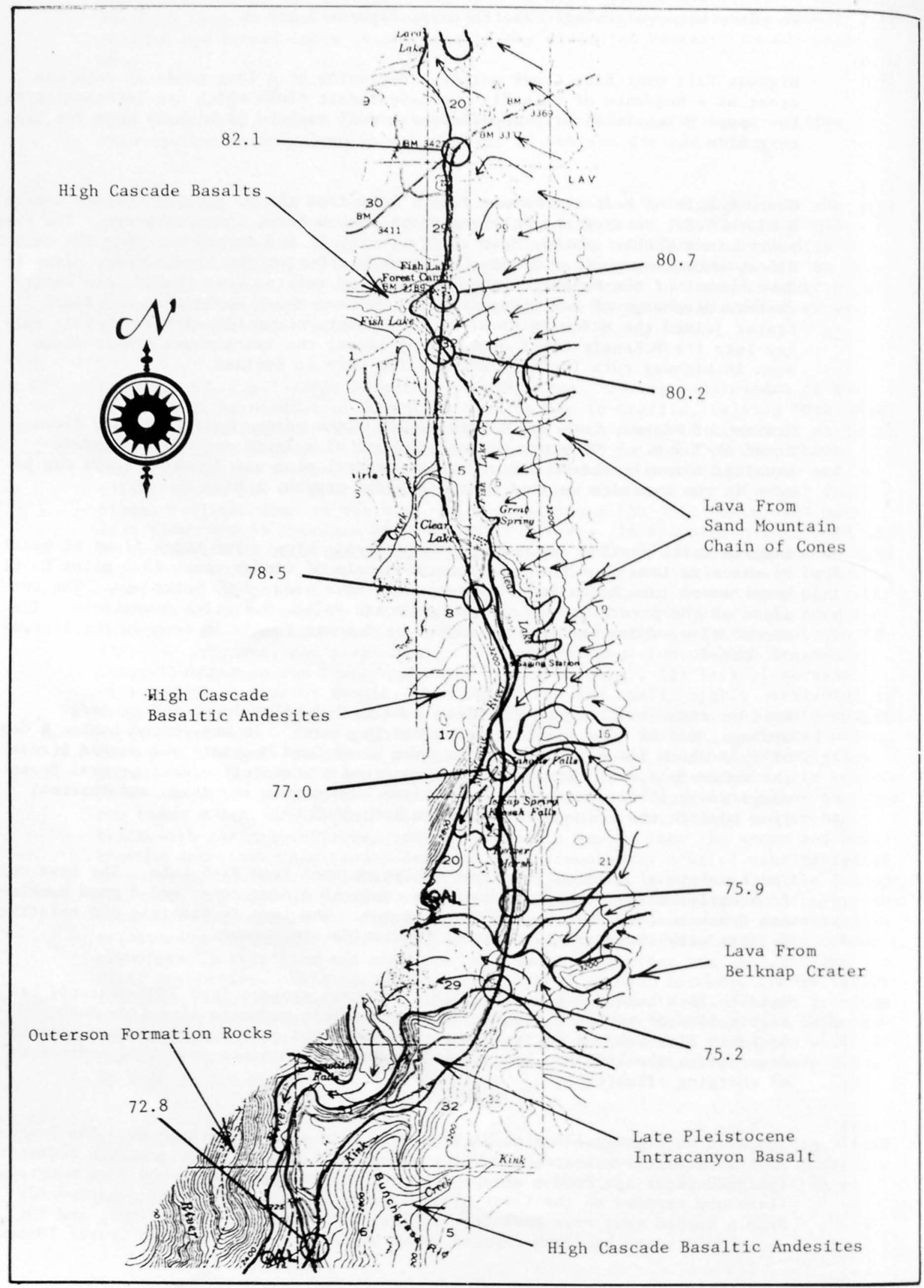

FIGURE 8. GEOLOGIC SKETCH MAP FROM MILE 72.3 TO MILE 83.5 
lava front about 200 feet S. of the junction).

(1.4)

83.5

$(0.6)$

84.1

$(0.6)$

84.7

(0.6)

85.3

$(1.0)$

86.3

(1.5)

87.8

(1.5)

89.3
Boundary between geologic sketch maps, Figures 8 and 9 . Sawyer's Cave, adjacent to the highway on the right, is a short lava tube with a well-preserved ropy crust on its eastern floor.

Gradual right-hand curve across a lava field composed of basaltic andesite flows (S.E. of the highway) from Nash Crater and younger flows (N.W. of the highway) from Little Nash Crater. Fine ash from Nash Crater fell on both of these flows, but the resulting deposit is thin and to be seen it must be recovered from interstices in the lavas.

Road to quarries in Little Nash Crater, left. Recommended side trip, but not suitable for a large bus. Follow gravel road to top of cone. Watch for trucks. Little Nash Crater has been breached on the W. by lavas which extend from the base of the breached area, westward for 1.7 miles. The quarried areas are littered with discarded volcanic bombs and bomb fragments up to 4 feet in diameter. The top of the cone affords a good view of the maturely dissected Western Cascade escarpment and nearby High Cascade Holocene cones and lava fields. Follow a gravel road $W$. and $N$. from the cone to Highway 22 and examine the large road cut $\mathrm{N}$. of 22 . It reveals a later Pleistocene terminal moraine mantled with a thin layer of Mazama ash, overlain by a bed of fine mafic ash from Nash Crater. This is overlain by coarse rock fragments blasted from bedrock and moraine over the Little Nash Crater vent. The top layer in the cut consists of mafic lapilli from Little Nash Crater. Turn E. on Highway 22.

Santiam Junction; Highways 20 and 22. Continue E. on 20. Late Pleistocene lateral moraines form ridges to the $\mathrm{N}$. and $\mathrm{S}$. of the junction area, outlining the last advance of glacial ice. Holocene volcanic activity in the junction area includes: (1) early basalt flows that moved N.W. toward Lava Lake from vents between Nash Crater and Sand Mountain, (2) basalt flows from Nash Crater, (3) development of the Lost Lake chain of cones and associated basalt flows, and (4) basaltic andesite flows from the S. and N.W. bases of Nash Crater. During this last phase of activity at Nash Crater, Little Nash Crater was formed and breached by flows of basaltic andesite. All of these volcanic episodes deposited lava or ejecta or both in the vicinity of Santiam Junction.

Broad left-hand curve around S. cone of Lost Lake chain of cinder cones. In this part of the chain, three cones were constructed across a glacial canyon and the resulting ridge dammed Lost Creek to form Lost Lake (one mile ahead). The cone $\mathrm{N}$. of the highway contains a crater 1000 feet wide and 300 feet deep.

In highway cuts and on hillside N. of the highway are several outcrops of columnar and platy-jointed basaltic andesite lava from a glaciated cone, 1.5 miles N.E., near Craig Lake. Older rocks in the $\mathrm{S}$. wall of this canyon have been dated by $\mathrm{K}-\mathrm{Ar}$ at $0.43 \mathrm{~m} . \mathrm{y}$. The lavas are overlain by a mantle of reworked mafic ash, chiefly from Lost Lake Cones and Little Nash Crater.

Broad left-hand curve around W. margin of Hogg Rock. Very well developed platy jointing in a glaciated volcanic dome of nearly aphyric andesite. Remnants of a columnar-jointed black glassy margin can be seen. View to the $N$. includes Three Fingered Jack; to the N.W., Maxwe1l Butte; to the W., Lost Lake chain of cones. Hoodoo Butte and Hayrick Butte can be seen to the S. Hoodoo is a cinder cone with a summit crater, shielded from Pleistocene glaciation by Hayrick Butte, which stood as an elongate andesite dome, in the path of the advancing ice. 


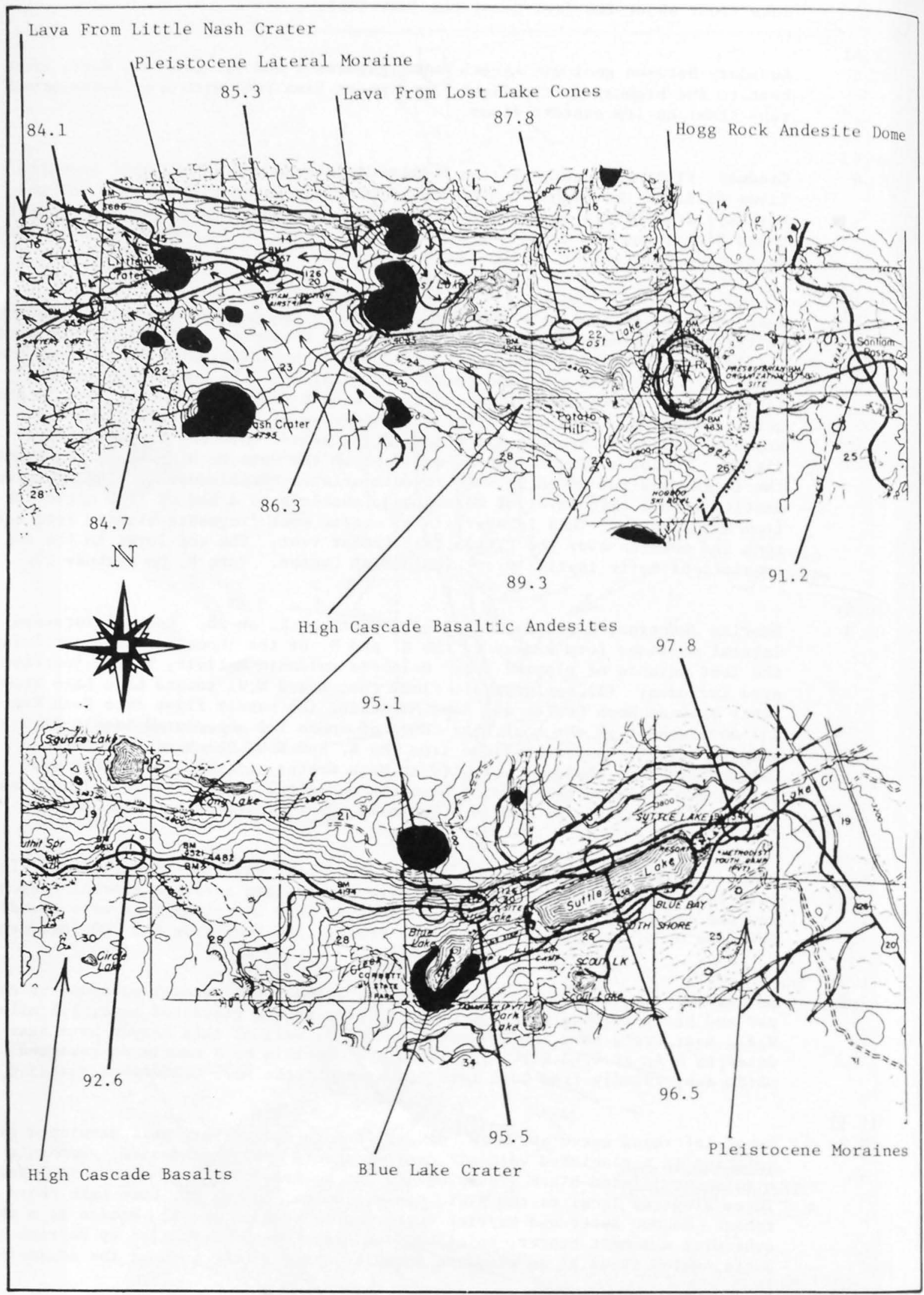

FIGURE 9. GEOLOGIC SKETCH MAPS FROM MILE 83.5 TO MILE 91.6 AND FROM MILE 91.6 TO MILE 99.8 

lavas which spread $E$. and $W$. from cones and lava vents along the High Cascade crestline from Highway 20, S. to Mount Washington. It should be noted that red cinders, so prevalent on road cuts between Little Nash Crater and Suttle Lake, have been deposited by snowplows and are not part of the natural stratigraphy.

$(1.4)$

92.6

$(2.5)$

35.1

(0.4)

95.5

(1.0) 96.5

(1. 3) 97.8

(2.0)

99.8

(1. 5)

101. 3

(2.6)

103. 9

Trailhead to Square Lake, left. From this point to the E. base of the High Cascade platform, basaltic andesite lavas of reverse paleomagnetic polarity are exposed in highway cuts.

Blue Lake overlook, right. Blue Lake occupies a Holocene crater surrounded by a rim of cinders, spatter, and bombs of basaltic andesite, ejected 3500 years ago. Although no lava appeared, the eruption must have occurred with considerable violence, for most of the crater was blasted out of solid bedrock and large fragments were scattered in all directions. The landscape is blanketed with cinders for 3 miles $\mathrm{E}$. and S.E.

\title{
Left-hand curve. Highway cuts in thick, platy-jointed basaltic andesite flows
} have been dated by $\mathrm{K}-\mathrm{Ar}$ at $0.54 \mathrm{~m} . \mathrm{y}$., but must be at least $0.7 \mathrm{~m} . \mathrm{y}$. because they possess reverse paleomagnetic polarity.

Midpoint of long downgrade N. of Suttle Lake. Glacial drift of a late Pleistocene lateral moraine which forms an E-W ridge 2 miles long and 600 feet high is exposed in N. side highway cuts. Suttle Lake rests in an elongate basin enclosed by lateral and terminal moraines. Cache Mountain and Mount Washington are prominent to the S.W.

Road to Blue Lake, right. Next 0.5 miles of highway will lead through late Pleistocene terminal moraines. This represents the lowest elevation reached by an eastward extension of the ice sheet which accumulated between Mount "Washington and Three Fingered Jack. The moraines are covered with 0.5 to 1.0 feet of fine ash from the Sand Mountain chain of cinder cones and by approximately 1 foot of younger cinders from Blue Lake Crater.

Boundary between geologic sketch maps, Figures 9 and 10. Highway leads over irregular surface underlain by a widespread field of Pleistocene diktytaxitic basalt flows.

\begin{abstract}
Junction. Leave Highway 20 , turn left on road to Metolius River and Camp Sherman. Route ahead will lead clockwise around the base of Black Butte. The butte is 3200 feet high and 4 miles in diameter. It is a composite cone of basaltic cinders and lavas constructed at the S. end of the Green Ridge fault escarpment. In spite of its youthful profile, Black Butte is older than many of the dissected High Cascade volcanoes such as Three Fingered Jack and Mount Washington, probably because it stands in the rain shadow of the Cascades. It has no summit crater, deep gullies are incised on its flanks, rocks on its surface have a relatively thick, weathered rind, and its lavas possess reverse paleomagnetic polarity. K-Ar ages average $0.45 \mathrm{~m} . \mathrm{y}$. , but the standard errors are large. The next 2 miles of roadway lead over a forested lava field of diktytaxitic basalt which overlies lavas from Black Butte.
\end{abstract}

\footnotetext{
Junction. Turn right on U.S.F.S. No. RD 14 to "Head of Metolius."
} 


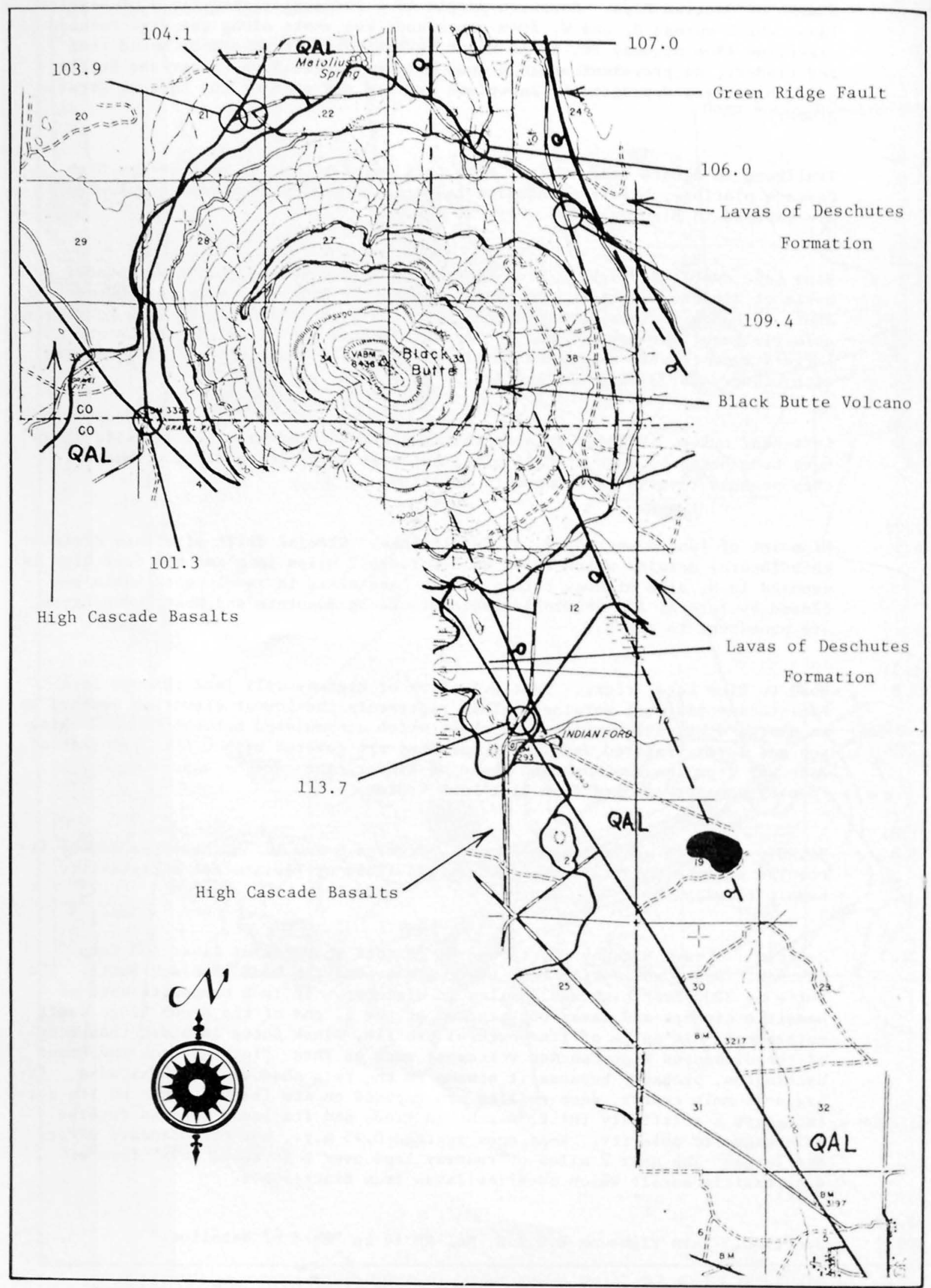

FIGURE 10, GEOLOGIC SKETCH MAP FROM MILE 99.8 TO MILE 119.0 
Secondary road, U.S.F.S. No. RD 1430, turn right and follow this road uphil1 for 3 miles. The Metolius River emerges from large springs at the $N$. base of Black Butte, 1 mile E. of this point. Black Butte and younger Cascade lavas buried the channel of a north-flowing ancestral Metolius River. Groundwater still moves through this channel, emerging at the $N$. margin of Black Butte lava. Large boulders of Black Butte lava are abundant along this road, but no outcrops will be seen.

(1.9) 106.0

(1.0) 107.0

(0.3)

107.3

(2.1) 109.4 (4.3) 113.7

(0.7)

119.7

124.6

(3. 0 )

127.6

Left-hand turn from N. slope of Black Butte to W. slope of Green Ridge. Intermittent outcrops of Pliocene mafic lavas separated by flow breccias will be seen for the next 1 mile.

STOP NO. 6: find viewpoint near top of grade. Parts of one of the most significant structural features on the E. flank of the central Cascades, namely the Green Ridge fault block, can be seen from this point. The west-facing escarpment extends $\mathrm{N}$. for 15 miles and rises 2000 feet above the Metolius River valley. Basalt, basaltic andesite, and andesite lavas with interbedded ashflow and air-fall tuffs ranging in age from 5.0 to $9.2 \mathrm{m.y}$. , occur in the face of the escarpment; they have been traced E. into the correlative Deschutes Formation. Magmas of Black Butte probably ascended through the Green Ridge fault zone and a well preserved mafic cinder cone and lava flow of Pleistocene age also rests on the fault trace, 3.0 miles N. of here. Several High Cascade peaks can be seen to the W. Most prominent are Mount Washington (S.W.), Three Fingered Jack (W.), and Mount Jefferson (N.W.).

Junction with Allingham Road, U.S.F.S. No. RD 1120. Turn right and follow RD 1120 south. The hillside visible about 0.5 miles E. is the S. end of the main Green Ridge escarpment; the roadway leads across part of a ramp structure between two parallel faults. Large altered boulders of Deschutes Formation lava will be seen along the roadside for the next 5 miles.

Junction with road leading E. (RD 1139). Continue south on U.S.F.S. RD 11 to rejoin Highway 20 .

Junction with Highway 20. Turn left toward Sisters. From here to Sisters the highway crosses a nearly flat alluvial plain chiefly consisting of late Pleistocene outwash sands and gravels from High Cascade glacial systems. The alluvium rests upon early Pleistocene lava flows and is overlain by late Pleistocene cinder cones and associated lavas.

Boundary between Geologic Sketch Maps, Figures 10 and 11. Junction of Highways 20 and 242; Town of Sisters. Proceed E. through Sisters.

Junction of Highways 20 and 126. Proceed S.E. on 20 toward Bend.

Junction of Gist Road and Highway 20. Proceed toward Bend on 20. For the next 2 miles, the highway crosses a flow of early High Cascade basalt porphyry which spread 9 miles N.E. and entered Deep Canyon in the Deschutes Basin.

Right-hand curve and junction of Fryrear Road with Highway 20. Low hills on both sides of the highway are composed of Pliocene basaltic andesite lavas near the top of the Deschutes Formation. Straight and level part of highway for 2.2 


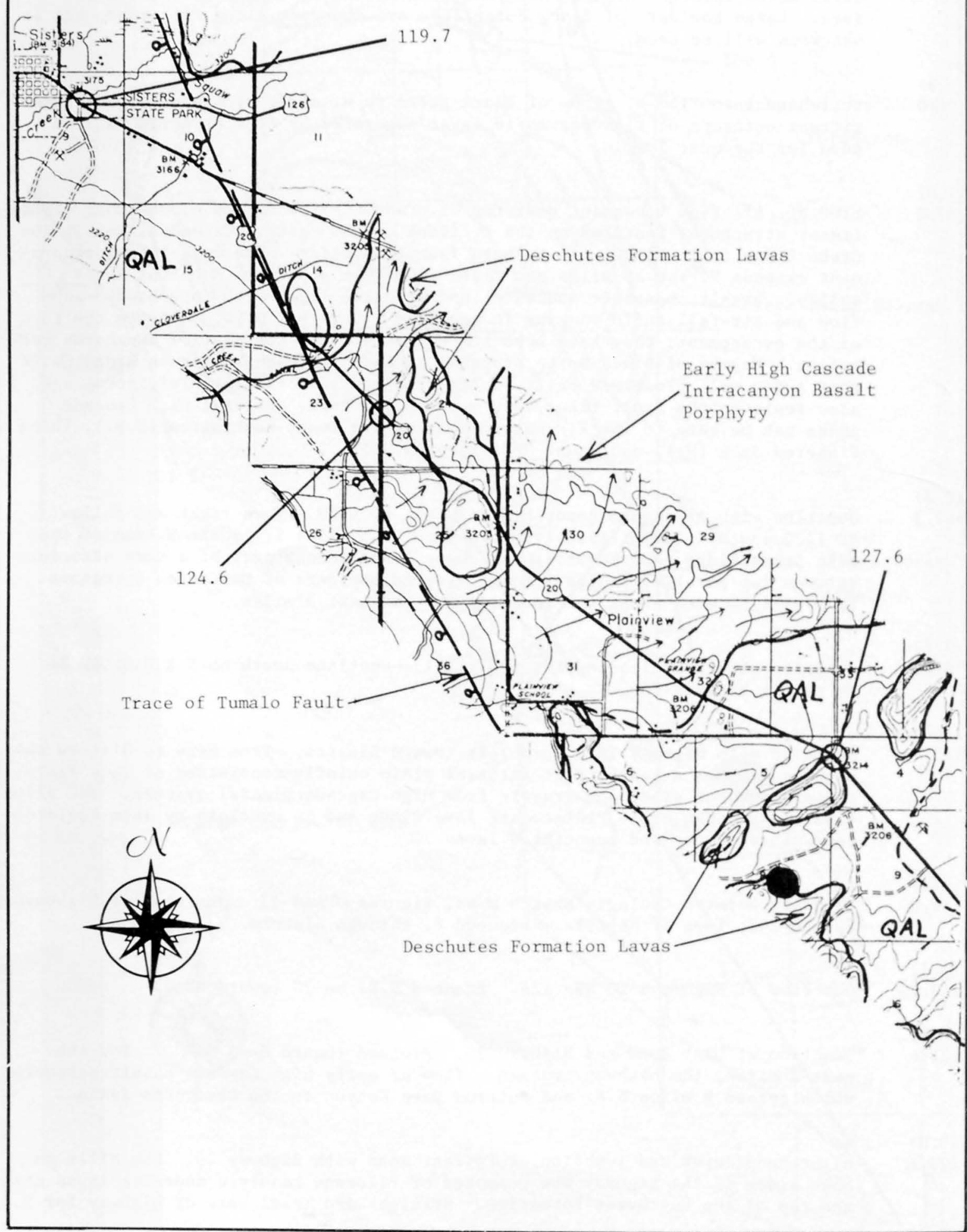

FIGURE 11. GEOLOGIC SKETCH MAP FROM MILE 119,0 TO MILE 129.1 
miles ahead is underlain by Desert Spring Tuff, obscured by alluvial cover toward the N.W.

(1.5)

129.1

$(0.2)$

129.3

(2.6)

131.9

(1.1)

133.0

$(0.5)$

133.5

(1.2)

134.7

$(1.3)$

136.0

(3. 3)

139.3

Boundary of Geologic Sketch Maps, Figures 11 and 12.

Gully trending N.E. has exposed pink Desert Spring Tuff in both banks. The ash flow moved N.W. in this area, toward Dry Canyon. Hill 0.7 miles E. is an early Pleistocene cinder cone.

Junction of Couch Market Road and Highway 20. The low hill E. of the highway is a small block of upper Deschutes Formation mafic lava bounded by northwesttrending normal faults. Dozens of such faults occur N.E. of the Tumalo Fault between Green Ridge and Bend; they are part of the Brothers-Sisters Fault Zone.

Laidlaw Butte on the right. Laidlaw is a Pleistocene cinder cone which was active after Desert Spring Tuff, Bend Pumice, and Tumalo Tuff were deposited in this area.

Right-hand curve and downgrade to floor of Deschutes River valley. Highway cuts along the grade expose pink nonwelded Tumalo Tuff in a position close to the N.E. margin of the Tumalo ash flow. The ash flow moved 3 miles farther N.E. and an unknown, but probably much greater distance eastward, where it is now buried beneath Pleistocene lava fields.

Highway 20 crosses Deschutes River. Alluvium on the valley floor has been quarried for gravel. Highway grade up the E. valley wall exposes Bend Pumice and Tumalo Tuff (which are underlain by Desert Spring Tuff at water level), overlain by gravel beds. At the top of the grade, basaltic lava flows rest upon the gravels.

One of several Highway cuts through basaltic lava which exposes pressure ridges in cross section. The lava was moving N.W. in this area from late Pleistocene vents on the N. flank of Newberry Volcano. The Deschutes River was forced westward to its present course along the west margin of the lava field. The city of Bend, E. of the river, has been built upon this lava field.

Junction of Highway 97 and route to city center. Turn right and proceed to downtown Bend. Turn right again at Newport Avenue. Proceed to College Way and completion of field trip circuit at 142.0 miles. 


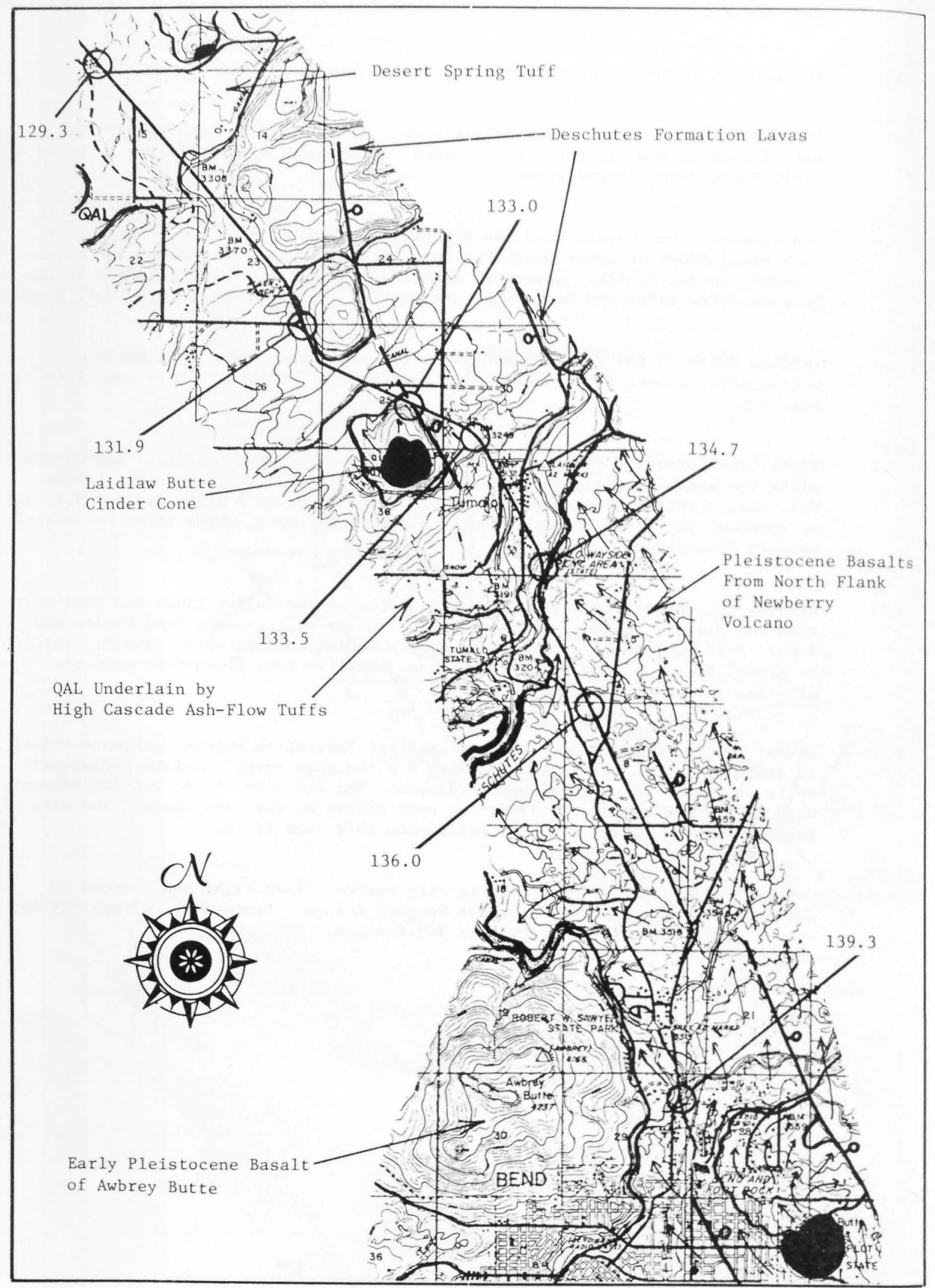

FIGURE 12. GEOLOGIC SKETCH MAP FROM MILE 129.1 TO MILE 142.0 


\section{REFERENCES}

Armstrong, R. L., Taylor, E. M., Hales, P. O., and Parker, D. J., 1975, K-Ar dates for volcanic rocks, central Cascade Range of Oregon: Isochron/West, No. 13, p. 5-10.

Peck, D. L., Griggs, A. B., Schlicker, H. G., Wells, F. G., and Dole, H. M., 1964, Geology of the central and northern parts of the Western Cascade Range in Oregon: U.S. Geol. Survey Prof. Paper 449, 56 p.

Peterson, N. V., Groh, E. A., Taylor, E. M., and Stensland, D. E., 1976, Geology and mineral resources of Deschutes County, Oregon: Ore. Dept. Geo1. Min. Ind., Bu11. 89, $66 \mathrm{p}$.

Scott, W. E., 1977, Quaternary glaciation and volcanism, Metolius River area, Oregon: Geol. Soc. Am. Bull., v. 88, p. 133-134.

Sutter, J. F., 1978, K-Ar ages of Cenozoic volcanic rocks from the Oregon Cascades west of $121^{\circ} 30^{\prime}$ : Isochron/West, No. 21, p. 15-21.

Taylor, E. M., 1968, Roadside geology, Santiam and McKenzie Pass Highways, Oregon: Ore. Dept. Geol. Min. Ind. Bul1., v. 62, p. 3-33.

, 1978, Field geology of S.W. Broken Top Quadrangle, Oregon: Ore. Dept. Geol. Min. Ind., Specia1 Paper 2, 50 p.

Thayer, T. P., 1937, Petrology of later Tertiary and Quaternary rocks of the north-central Cascade Mountains in Oregon: Geol. Soc. Am., Bul1. 48, p. 1611-1652. 
NEWBERRY VOLCANO, OREGON

Norman S. Macleod, David R. Sherrod, U.S. Geological Survey, Menlo Park, California 94025

Lawrence A. Chitwood, U.S. Forest Service, Bend, Oregon 97701

and

Edwin H. McKee, U.S. Geological Survey, Menlo Park, California 94025

\section{GEOLOGIC SUMMARY}

Newberry Volcano, centered about 20 miles southeast of Bend, Oregon, is among the largest Quaternary volcanoes in the conterminous United states. It covers an area in excess of $500 \mathrm{mi}^{2}$, and lavas from it extend northward many tens of miles beyond the volcano. The highest point on the volcano, Paulina Peak with an elevation of $7,984 \mathrm{ft}$, is about 4,000 ft higher than the terrain surrounding the volcano. The gently sloping flanks, embellished by more than 400 cinder cones, consist of basalt and basaltic andesite flows, andesitic to rhyolitic ash-flow and air-fall tuffs and other types of pyroclastic deposits, dacite to rhyolite domes and flows, and alluvial sediments produced during periods of erosion of the volcano. At Newberry's summit is a 4- to 5-mile-wide caldera that contains scenic Paulina and East Lakes. The caldera has been the site of numerous Holocene eruptions, mostly of rhyolitic composition, that occurred as recently as 1,400 years ago.

Many geologists have studied various aspects of Newberry Volcano starting with I. C. Russell (1905) who visited it during a horseback reconnaissance of central and eastern Oregon in 1903. Howell Williams (1935, 1957) mapped the flanks of the volcano in reconnaissance and studied the caldera in more detail. His outstanding work forms the basis for subsequent investigations, most of which have focused on caldera rocks or young flank basalt flows. No comprehensive study has been made of the geology of Newberry's forest-covered and Mazama ashcovered flanks even though they form more than 95 percent of the area of the volcano. As part of a geothermal resource investigation of central and eastern Oregon, the first three authors have mapped the sixteen $7-1 / 2^{\circ}$ quadrangles that cover the flanks of Newberry at a scale of 1:62,500, and reinterpreted and partly remapped the caldera. Highly generalized geologic sketch maps are shown in figures 1 and 2 . The new mapping and $\mathrm{K}-\mathrm{Ar}$ dating by the last author require substantial reinterpretation of the history of the volcano and of formation of the caldera and subsequent volcanic activity within it.

Newberry lies 40 miles east of the crest of the Cascade Range in a setting similar to Medicine Lake Volcano in California (Donnelly and others, this vol.). Both volcanoes have the same shape, are marked by summit calderas, contain abundant rhyolitic domes and flows, have widespread ash flows in addition to the more areally extensive basalt and basaltic-andesite flows and their related cinder cones, have similar petrochemistry, and have been the sites of eruptions of pumiceous tephra and obsidian flows during the last few thousand years.
Newberry lies at the west end of the High Lava Plains, a terrain formed of Miocene to Quaternary basalt flows and vents punctuated by rhyolitic domes and vent complexes (Walker and others, 1967; Greene and others, 1972; Walker and Nolf, this vol.). The rhyolitic rocks show a well-defined monotonic age progression starting at about $10 \mathrm{~m} \cdot \mathrm{y}$. east of Harney basin and decreasing to less than $1 \mathrm{~m} \cdot \mathrm{y}$. at Newberry's eastern border (Walker, 1974; MacLeod and others, 1975; McKee and others, 1976). Newberry rhyolites appear to be a continuation of these ageprogressive rhyolitic rocks.

A complexly faulted terrain surrounds Newberry. The northeast-trending Walker Rim fault zone impinges on Newberry's southern flank but offsets only its older flows. A zone of faults that offsets older flows on the lower northern flank extends northwestward into the Cascade Range at Green Ridge. Although Newberry lavas obscure the relations of the Walker Rim and Green Ridge fault zones, they likely join beneath Newberry and represent but one curving fault system. The Brothers fault zone, a major west-northwest-trending zone of faults, extends across the extreme northeastern flank but does not apparently offset surficial Newberry flows. It probably extends at depth to join or abut against the Green Ridge-Walker Rim fault zones.

The north and south flanks of Newberry Volcano, which extend the greatest distances from the summit caldera, are almost exclusively veneered by basalt and basaltic andesite flows and associated vents. The basalt flows form much of the surface in a broad region extending far north of the volcano (Peterson and Groh, 1976) as well as southward to the Fort Rock basin. Individual flows are a few feet to more than $100 \mathrm{ft}$ thick and cover areas of less than 1 square mile to many tens of square miles. Flow margins are commonly well preserved even on older flows, but the flows are complexely interwoven and it is difficult and time consuming to trace individual flow boundaries. Most flows are of block or aa type; pahoehoe surfaces occur locally on a few lower flank flows. Lava tubes are common, and some extend uncollapsed for distances of 1 mile (Greeley, 1971); some lower flank flows may have been fed by tube systems. Casts of trees occur in many flows, particularly the younger ones.

The basalt and basaltic andesite flows can be readily divided into two groups on the basis of their age relative to Mazama ash $\left({ }^{14} \mathrm{C}\right.$ age $6,600-$ 6,700 years) derived from the volcano at Crater Lake 70 miles distant. The youngest lava flows overlie Mazama ash, and their ${ }^{14} \mathrm{C}$ ages range from 5,800 to 6,380 years $\left({ }^{14} \mathrm{C}\right.$ ages of this magnitude are generally about 800 years younger than actual 


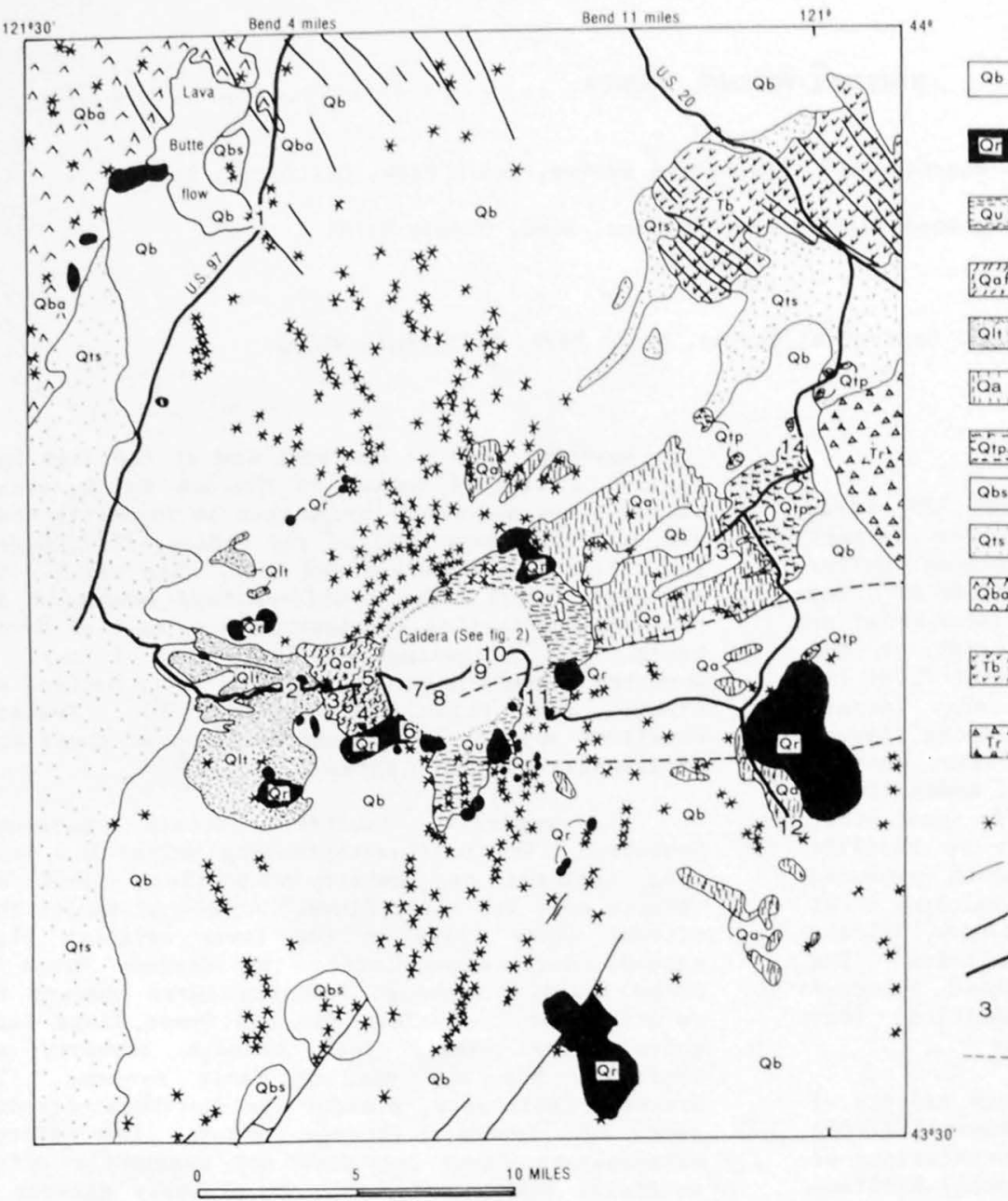

Qb Unditlerentiated basalt and basaitic andesite flows (Lava Butte flow is labeled), earty Pleistocene to Holocene

Rhyolite to dacite domes. Hows. pumice rings. and vent complexes: early Pleistocene to Holocene

Qu Undifferentiated pumice talls, ash flows, and alluvial Jeposits of the upper flanks. Pleistocene and Holocene

Ash flow fuffs and aggiutinated pyroclastic tocks of upper west tlank. Pleistocene

Lif Lapili futf of west tiank. Pleistocene

Undifterentiated alluvial deposits with interbedded lapilit tutt (Qit). ash flow tuth and pumice fall deposits. Pleistocene

Qtp:- Ash flow tuft of Teepee Draw; Pleistocene

Qbs Basalt and pasaltic andesite of small shields. Pleistocene

Qis Fluvial and lacustrine sediments: Pleistocene and Pliocenel?

asait, basaltic andesite, and andesite flows, ast flow tufts. and pumice tall deposits of the Cascade Range, Pleistocene

ib:- Basait flows and interbedded cinders and scoria deposits, late Miocene

A Q Rhyolite to andesite flows, domes, and pyrociastic rocks of the Pine Mountain area, early Miocene

* Cinder cones and fissure vents

Contact

Fault

Field thip route

3 Field trip stop

$10^{-1}$ isopach of young pumice fall

Figure 1. Geologic sketch map of Newberry Volcano.

Geology of the caldera is shown in figure 2.

ages). Carbon for isotopic dating was obtained from carbonized root systems at the bases of lava tree casts (Peterson and Groh, 1969) and from beneath cinder deposits that extend as plumes leeward of cinder vents related to the flows (Chitwood and others, 1977). The young flows may have erupted during a much shorter period of time than the age spread indicates, perhaps as little as a few weeks or several years. All other flows are covered by Mazama ash and are older than $6,700{ }^{14} \mathrm{C}$ years; surface features on some flows suggest a relatively young age, perhaps 7,000 to 10,000 years, others are likely several tens or hundred of thousands of years old.

Seventy-three basaltic to andesitic flow rocks or bombs from associated vents analyzed by Higgins (1973) and Beyer (1973) contain 48 to 60 percent $\mathrm{SiO}_{2}$. The mean silica content of these rocks is about 54 percent, similar to that of analyzed rocks from the adjacent Cascade Range. Of these analyzed Newberry rocks, only about 20 percent contain less than 52 percent $\mathrm{SiO}_{2}$, about 60 percent lie between 52 and 56 percent, and the remaining 20 percent have 56 to 60 percent. Thus the dominant analyzed rock type is basaltic andesite similar to many rocks in the Cascade Range. The analyzed rocks are generally biased toward younger rocks, however, and many of the older voluminous flows on the lower flanks are basalt, mostly of high-alumina type (table 1, col. 1). The 6,000-year-old flows contain 52 to 57 percent $\mathrm{SiO}_{2}$ and are basaltic andesites (table l, col. 2).

More than 400 cinder cones and fissure vents have been identified on the flanks of Newberry--fev other volcanoes in the world contain so many. They are concentrated in three broad zones that join on the upper part of the volcano. The eastern zone is a continuation of the High Lava Plains zone of basaltic vents and parallels the Brothers fault zone; except for cones high on the east flank, most cones in this zone appear relatively old. The northwestern zone of vents is collinear with the zone of faults on the lowermost flank that extends to Green Ridge in the Cascade Range, and the southwestern zone is collinear with the Walker Rin fault zone. Fissures and alined cinder cones generally parallel the belts in which they occur. The distribution of the vents, and particularly of alined vents and fissures, suggests that the northwest and southwest zones, and perhaps the faults that they parallel, are part of one broad arcuate zone that curves in the vicinity of Newberry's summit. Some alined cinder cones and fissure vents near the summit occur in arcuate zones 
arallel to the caldera rim and likely lie along ing fractures; some occur along faults whose aldera side is downdropped.

Most of the cinder cones are well preserved ving to their high porosity and consequent ibsorption rather than runoff of water. Larger absorptire as much as $500 \mathrm{ft}$ high, typical cones are 200 to $300 \mathrm{ft}$. Most are marked by summit craters flows emerge from their bases. Cinders dispersed by prevailing winds during eruptions form drons extending leeward from some cones such as lava Butte (Chitwood and others, 1977) (stop 1, road Lissure vents consist of long ridges or trenchlike depressions formed by cinders, spatter and agglutinate flows. Small pit craters are developed along some fissure vents. Cinder cones and fissure vents on the lower flanks are generally devold of fragments of rhyolitic rock, whereas many of those higher on the volcano contain rhyolitic inclusions (stop 3, road $\log$ ).

Shieldlike vents occur at Spring and Green Butte on the southwest flank and Green Mountain to the northwest of Newberry. They are 1 to 3 miles across, have gentle slopes, and are more faulted and older than most surficial Newberry flows.

Many of the hills on Newberry's flanks are rhyolitic domes. In addition, pumice rings, obsidian flows, and small rhyolite or obsidian protrusions occur in many places. Most of the domes form rounded hills, such as McKay Butte on the west flank, that are 100 to $500 \mathrm{ft}$ high and up to 4,000 $\mathrm{ft}$ across. The largest dome, which forms Paulina Peak (stop 6, road $\log$ ), extends southwestward from the caldera wall for 3 miles. Its very elongate outcrop suggests that it was emplaced along a northeast-trending fissure or fault; an obsidian flow crops out farther down the slope on a direct extension of the axis of the Paulina Peak dome and nay have been erupted from the same buried fissure or fault.

Several small rhyolitic outcrops may be the tops of rhyolite domes that are more extensive at depth. An example is along Paulina Creek on the west flank of Newberry where obsidian irregularly invades basaltic andesite flows over a small area. In addition, the common occurrence of rhyolite as fragments in cinder cones on the upper flanks attests to the relative abundance of rhyolite at depth on the upper part of the volcano.

$\mathrm{K}-\mathrm{Ar}$ ages were determined on six rhyolite domes and flows. The ages range from 400,000 to 700,000 years, although many undated rhyolites are probably younger. Some small spinal protrusions, domes, and pumice rings on the upper southeast flank may be less than 10,000 years old. In contrast to the relative antiquity of many rhyolites on the flanks, those in the caldera are commonly younger than Mazama ash and as young as 1,400 years.

Ash flows, pumice falls, mudflows, and other pyroclastic deposits are common on the west and east flanks of Newberry and are likely present at depth on the north and south flanks below the veneer of basalt and basaltic andesite flows. The oldest known unit occurs on the lower northeast and east flank and consists of a widespread rhyolitic ash flow identified by G. W. Walker (pers. commun., 1973) during reconnaissance mapping of adjacent areas to the east. It has been referred to informally as the Teepee Draw ash flow for outcrops along Teepee Draw (stop 14, road $10 \mathrm{~g}$ ). The Teepee Draw ash flow crops out along ravine walls for at least 6 miles toward the caldera before being buried by younger rocks. Along some ravines it exceeds 70 $\mathrm{ft}$ in thickness, but it may be considerably thicker because its base is exposed only where kipukas of older basalt project through it; also the upper part is eroded. The ash flow crops out roughly over a $50^{\circ}$ quadrant of the volcano, and, as it is apparently older than the surficial rocks on the other flanks, may be present at depth completely around the volcano. Original volume of the unit is difficult to estimate without information on distribution at depth on the other flanks, but it likely is much more than 10 cubic miles. The Teepee Draw ash flow probably relates to an early, perhaps the earliest, period of caldera collapse.

Farther up the northeast flank the Teepee Draw ash flow is buried to progressively greater depth by alluvial sediments derived by erosion of rocks higher on the slopes. Interbedded in or underlying this alluvium are basalt and andesite flows, and several other ash-flow tuff units (stops 12 and 13, road $\log$ ). Some of these ash flows are widespread, others occur in only a few scattered localities (commonly plastered on the caldera side of cinder cones). Most of these post-Teepee Draw ash flows are characterized by dark-colored, probably dacitic, pumice.

The west flank of the volcano contains two major tephra units. The older unit forms most of the lower two-thirds of the slope and overlies basalt flows and vent deposits that in many places are deeply eroded. This unit also occurs on the northeast flank where it occurs higher in the section than most of the ash flows. Although locally over $200 \mathrm{ft}$ thick, it is rarely exposed. Most of the scree-covered roadcuts along the paved road on the west flank that leads to the caldera are in this unit (stop 2, road $10 \mathrm{~g}$ ). The unit consists of gray to black ash, lapilli, and small bombs and abundant accidental lithic fragments. The lapilli and bombs have characteristic cauliflowerlike surfaces and virtually all contain angular to rounded inclusions of rhyolite, dacite, and andesite; some inclusions are fused and frothed. Trenches dug in the deposit show that it is massive. In no place have we seen any indication of collapse of pumiceous lapilli or welding. All of the lapilli and bombs, as well as the ashy matrix, have the same normal natural remnant magnetization, as measured by a field fluxgate magnetometer, which suggests emplacement temperatures above the Curie point for the entire unit. Most of the unit was likely deposited as pyroclastic flows. In one area the unit is palagonitized and much more indurated and has characteristics more like that of a lahar. Lapilli and bombs identical to those in this unit are an ubiquitous and voluminous component of most alluvial deposits on the volcano. Furthermore, numerous gravel pits beyond the flanks of the volcano contain similar lapilli as a major component of the gravel. The original volume of the unit was probably several cubic miles. Its eruption could have been accompanied by caldera collapse.

The second major tephra unit on the west flank forms the smooth and gently dipping upper part of the flank extending for about 2 miles from the caldera rim. At localities farthest from the rim (stop 4, road $\log$ ) the unit consists of many thin ash-flow units, commonly 3 to $20 \mathrm{ft}$ thick. They are reddish to brownish in color and consist of 
andesitic scoria and pumice and accidental lithic fragments in a poorly sorted lithic- and crystal-rich ashy matrix. Bases of individual units are commonly welded. Toward the caldera rim, the ash flows progressively change character and in many places near the rim, as at Paulina Falls (stop 5, road $(0 g)$, thick units have the appearance of agglutinate flows. These deposits probably represent hot co-ignimbrite lag deposits.

Alluvial deposits occur over broad areas of the northeast, lower southeast, and upper south flanks where they form rounded slopes with virtually nonexistent exposure. Most of the deposits are gravel and sand, but the occurrence of boulders as float at some horizons along sides of ravines indicates that boulder beds are present also; pumice falls and ash flows are interbedded in the alluvial deposits in some areas. Because most of the uppermost slopes of the volcano in areas where the alluvium is present are veneered by young pumice falls, we were not able to determine the origin of the deposits near the caldera. They may be fluvial but equally well may be of glacio-fluvial or glacial origin. Farther down the slope they are probably entirely fluvial, representing broad alluvial fans.

Much of the uppermost northeast, east, and southern flanks extending for about 1 to 2 miles outward from the caldera rim are formed of pumice and ash deposits derived from vents within the caldera. Most of the deposits are younger than Mazama ash, but scattered holes dug through them show that similar deposits underlie Mazama ash in a few places. Much of the east flank of the volcano is covered by an extensive pumice fall (stop 11, road $(0 \mathrm{~g}$ ) derived from the vent for the Big Obsidian flow in the caldera (Sherrod and MacLeod, 1979). It extends as a plume oriented N. $80^{\circ}$ E., is well over $10 \mathrm{ft}$ thick near the caldera rim, and thins to about $10 \mathrm{in}$. at a distance of about 40 miles from the caldera.

Williams (1935, 1957) first recognized that the 4- to 5-mile-wide depression at the summit of the volcano is a caldera; Russell (1905) had originally suggested that it was a large glacial cirque. Owing to the absence of known ash flows on the flanks, Williams (1957) interpreted the caldera as resulting from "* * * drainage of the underlying reservoir either by subterranean migration of magma, or, more likely, by copious eruptions of basalt from flank fissures * * *," with summit collapse occurring along ring fractures. Higgins (1973), on the other hand, interpreted caldera formation as due to tectonic-volcanic collapse along fault zones that supposedly intersected at the summit. As noted by Peterson and Groh (1976), the main axis of the Brothers fault zone lies far north of the caldera, rather than crossing the summit, and faults within the zone do not appear to offset Newberry lavas. Also, most of the faults shown by Higgins on the upper part of Newberry that he uses as part of his structural interpretation could not be corroborated.

Ash flows and other tephra units are now known to be common and voluminous on the flanks. Thus the caldera seems much more likely to be the result of voluminous tephra eruptions from magma chambers below the former summit with concomitant collapse of the summit in a manner similar to that of most other calderas the size of Newberry's or larger. As there were several major tephra eruptions, it seems likely that collapse occurred several times, each collapse involving areas smaller than that of the present caldera. Accordingly, the present caldera interpreted as several nested calderas of different age.

The ages of the calderas and of the ash flows that we consider to be related to their formation are poorly known. Higgins (1973) interprets the caldera age as Holocene on the basis of the absence of obvious widespread glacial deposits. However, many rocks on the volcano, particularly on its uppe flanks, are now known to be several hundred thousan years old, so absence of glacial features probably is not meaningful. Also, several of the large: volcanoes on the east side of of the Cascade crest, which are about the same height as Newberry, show obvious glacial features, yet some of them ate nearly a million or more years old.

The ring fractures along which collapse occurred are not exposed, yet their general location is indicated by arcuate zones ( $f \mathrm{ig} .2$ ), visible on aerial photographs. It is not possible to relate individual ash-flow units to collapse along specific ring fractures. Also it is possible that collapse occurred along parallel ring fractures at the same time. Two parallel walls on the southeast side of the caldera present an interesting problem in interpreting the origin of the caldera wall sequences (described later). If the inner wall is the younger, then the area between the inner and outer wall may be formed of old caldera-fill deposits. The inner wall is thickly mantled by young tephra deposits, and the only exposures are a relatively small area of rhyolite in the lower part of the slope. The remainder of the slope on this wall dips $30^{\circ}$ to $40^{\circ}$, near the angle of repose, and has a very uniform smooth shape. If the young tephra deposits were locally underlain by indurated rocks, as are present in the other walls, it seens likely that the slope would be more 1rregular. Thus this caldera wall likely is dominantly or entirely formed of relatively unconsolidated fragmental rocks, probably caldera-fill deposits. The rhyolite exposed locally at the base of the wall may be a faulted dome that was originally within the caldera. The upper part of the northeast wall, above exposures of caldera wallrocks, may also be formed of caldera-fill deposits, the older caldera wall being farther north.

The walls of the caldera are mostly covered by younger deposits (talus, pumice falls, etc.) and the wallrocks are only locally exposed. They are described by Williams (1935) and in more detail by Higgins (Higgins and Waters, 1968; Higgins, 1973). The most continuous exposures are along the north wall extending from the Red Slide, north of Paulina Lake, to the northeast obsidian flow, which drapes the wall northeast of East Lake. The base of the wall sequence is formed of platy rhyolite. Higher in the section are basaltic andesite flows, palagonite tuff, cinder and agglutinated spatter deposits, and at the top of the exposures are palagonite tuffs.

Exposures in the east wall are found only from about midway on East Lake northward to the Sheeps Rump, a cinder cone along the wall at the northeast corner of the caldera. The intermittent exposures consist of basaltic andesite or andesite flows, palagonite tuff, and pumice deposits. The last range from unwelded and uncollapsed pumice to densely welded deposits. 


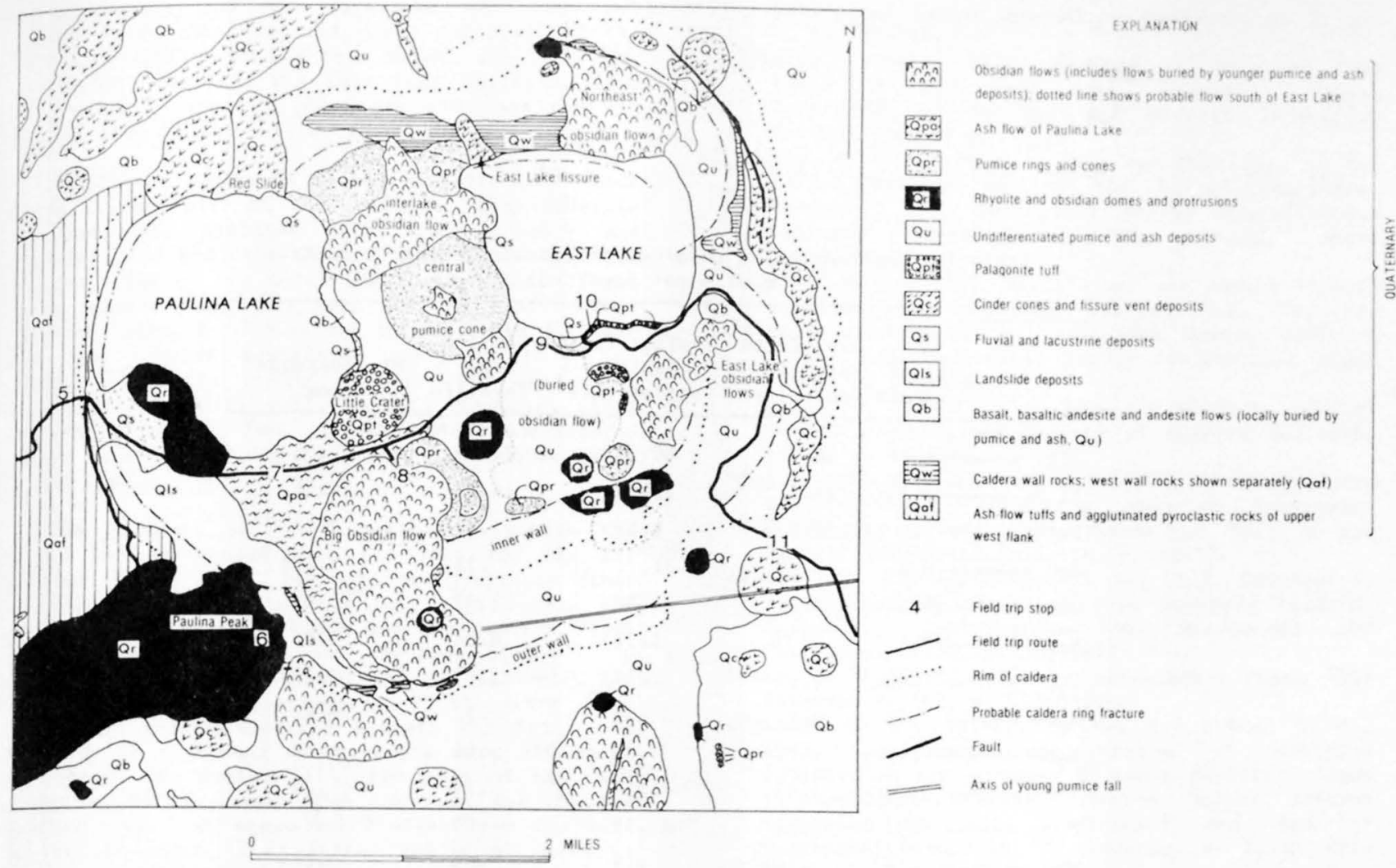

Figure 2. Geolocic sketch map of Newberry caldera.

Other than exposures of rhyolite south of East Lake, the inner south caldera wall is unexposed and is covered by thick pumice fall deposits. The outer south wall has exposures only near the Big Obsidian flow and farther west below Paulina Peak. The best exposures, midway between Paulina Peak and the $\mathrm{Big}$ Obsidian flow, consist of a lower platy rhyolite, overlain by basaltic andesite flows, dikes, and cinder deposits with local interbedded pumice fall deposits, and with a cliff-forming obsidian flow at the top. At the west end of this exposure are outcrops of bedded pumiceous tuffs that have been fused near their contact with the overlying obsidian flow; part of the apparent base of the obsidian flow is fused tuff even on the east end of the outcrop. South of the Big Obsidian flow vent are exposures of andesitic or dacitic ash flows and basaltic andesite flows, and below Paulina Peak a ledge of basalt crops out in one small area.

Most of the caldera floor is formed of rhyolitic rocks including domes, flows, and pumiceous tephra deposits (ash flows, pumice falls, explosion breccias), but basaltic andesite and andesite flows and palagonite tuff rings occur in several places. Williams (1935) and Higgins (1973) have provided much useful data on the floor rocks, although we interpret the relative ages of many of the units differently. The floor rocks represent but the tip on the iceburg with respect to the total f111 present in the caldera. A core hole, currently being drilled for the U.S. Geological Survey has so far penetrated $1,700 \mathrm{ft}$ of caldera-fill deposits, mostly pumiceous tephra, with a few rhyolitic and dacitic flows, and lake sediments $1,000 \mathrm{ft}$ below the surface.
Mazama ash is a useful datum with which to roughly subdivide the caldera rocks as older or younger than about $6,700{ }^{14} \mathrm{C}$ years. All the mafic rocks are older than Mazama except for those along the East Lake fissure. The East Lake fissure has not yielded carbon for dating, but the summit basaltic andesite flows along the same fissure less than a mile north are about $6,090{ }^{14} \mathrm{C}$ years old (S. W. Robinson, written commun., 1978). Included in the pre-Mazama basaltic rocks are the interlake basaltic andesite flow (east shore of Paulina Lake), Red Slide cinder vent and flows (north side of Paulina Lake), Sheeps Rump cinder cone and flow (northeast side of East Lake), and east-rim fissure and the associated flow from it that extends to East Lake. The palagonite tuff rings that occur southeast of Paulina Lake (Little Crater) and near the south shore of East Lake (stop 10, road log) are also pre-Mazama in age. Rhyolitic rocks of preMazama age include two domes along the south shore of Paulina Lake, a large obsidian flow in the northeast corner of the caldera, an obsidian dome that crops out near the caldera wall south of East Lake with an obsidian flow that extends northward from the dome to East Lake, and a poorly exposed dome(?) south of the Central Pumice cone. In addition, rhyolitic pumice falls, lacustrine deposits (i.e., east shore of Paulina Lake), and landslide deposits (north of Paulina Peak) are known to locally underlie Mazama ash.

The post-Mazama rhyolitic deposits occur in the eastern half of the caldera ( $f i g .2)$. They include obsidian flows, pumice rings and cones, ash flows, pumice falls, and other pumiceous tephra deposits. Hydration-rind dating by Friedman (1977) indicates that the Central Pumice cone, between East and 
Table 1. Representative chemical analyses of Newberry rocks. $[\mathrm{n} \cdot \mathrm{r} \cdot \mathbf{n}=$ not reported]

\begin{tabular}{|c|c|c|c|c|c|c|}
\hline & $\begin{array}{l}\text { Flank } \\
\text { basalt }\end{array}$ & $\begin{array}{l}\text { Lava Butte } \\
\text { basaltic- } \\
\text { andesite }\end{array}$ & $\begin{array}{l}\text { Paulina Falls } \\
\text { andesitic- } \\
\text { agglutinate }\end{array}$ & $\begin{array}{l}\text { Paulina } \\
\text { Peak } \\
\text { rhyolite }\end{array}$ & Big & $\begin{array}{l}\text { Obsidian } \\
\text { flow }\end{array}$ \\
\hline $\mathrm{SiO}_{2}$ & -49.1 & 56.0 & 60.43 & 71.07 & & 72.02 \\
\hline $\mathrm{Al}_{2} \mathrm{O}_{3}$ & -17.6 & 16.1 & 16.06 & 14.92 & & 14.61 \\
\hline 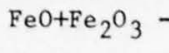 & -9.0 & 7.7 & 6.51 & 2.81 & & 2.43 \\
\hline $\mathrm{MgO}$ & -8.9 & 4.49 & 1.71 & .22 & & .164 \\
\hline $\mathrm{CaO}$ & -10.0 & 8.2 & 4.58 & 1.08 & & .85 \\
\hline $\mathrm{Na}_{2} \mathrm{O}$ & -2.6 & 3.72 & 5.71 & 6.04 & & 5.16 \\
\hline $\mathrm{K}_{2} \mathrm{O}$ & -.43 & 1.25 & 1.54 & 3.03 & & 3.89 \\
\hline $\mathrm{H}_{2} \mathrm{O}+\cdots$ & -.71 & $\mathrm{n} \cdot \mathrm{r}$. & $.53^{\circ}$ & .17 & & $\mathrm{n} \cdot \mathrm{r}$. \\
\hline $\mathrm{H}_{2} \mathrm{O}-\cdots$ & -.10 & $\mathrm{n} \cdot \mathrm{r}$. & .07 & .01 & & $\mathrm{n} \cdot \mathrm{r}$. \\
\hline $\mathrm{TiO}_{2}$ & -1.0 & 1.13 & 1.30 & .29 & & .24 \\
\hline $\mathrm{P}_{2} \mathrm{O}_{5} \ldots$ & -.31 & $\mathrm{n} \cdot \mathrm{r}$. & .59 & .05 & & $\mathrm{n} \cdot \mathrm{r}$. \\
\hline $\mathrm{MnO}$ & -.16 & .14 & .15 & .09 & & .064 \\
\hline $\mathrm{CO}_{2}$ & $-<.05$ & $n \cdot r$. & .61 & $<.05$ & & $n \cdot r$. \\
\hline
\end{tabular}

Column 1. Higgins (1973, table 6, col. 62).

Column 2. Beyer (1973, table 1c, LB-4).

Column 3. Higgins (1973, table 4, col. 19).

Column 4. H1ggins (1973, table 4, col. 27).

Column 5. Laldley and McKay (1971), average of 66 analyses. 
Paulina Lakes, and the Interlake and Game Hut obsidian flows that crop out north and south of it, are only slightly younger than Mazama ash $\left({ }^{14} \mathrm{C}\right.$ age, $6,600-6,700$ years). The East Lake obsidian flows are apparently about 3,500 years old, and the Big obsidian flow is about 1,400 years old.

Widespread pumiceous tephra deposits cover much of the eastern part of the caldera. They underlie the East Lake obsidian flows and probably are slightly older than the Central Pumice cone and the obsidian flows on its north and south sides. These tephra deposits may have been derived from several different vents, but holes dug through them indicate that they consist dominantly of 5 to $10 \mathrm{ft}$ of massive to poorly bedded pumice with accidental fragments (palagonite tuff, basalt, rhyolite, etc.) overlain by several feet of well-bedded mud-armored pumice, accretionary lapilli, ash, and pumice (stop 9 , road $\log$ ).

The youngest period of volcanism within the caldera was associated with the vent for the Big obsidian flow. It began with eruptions that produced a widespread pumice fall that covers the southern part of the caldera and the eastern flank of the volcano (Sherrod and MacLeod, 1979). ${ }^{14} \mathrm{C}$ ages of 1,720+200 (Higgins, 1969) and $1,550 \pm 120$ (s. W. Robinson, written commun., 1978) years were obtained on carbon directly beneath the fall. On the basis of thickness measurements from 150 holes dug through the pumice fall, the axis of the fall extends N. $80^{\circ}$ E., away from the vent for the Big obsidian flow. At about $5-1 / 2$ miles from the vent the fall is about $12 \mathrm{ft}$ thick, and at 40 miles it decreases to about $10 \mathrm{in}$.

The pumice fall was followed by eruptions that produced an ash flow that extends over a broad area between the Big Obsidian flow and Paulina Lake. It is well exposed in roadcuts, near the Big Obsidian flow (stop 7 , road $10 \mathrm{~g}$ ). ${ }^{14} \mathrm{C}$ ages of the ash flow are $1,270 \pm 60$ and $1,390 \pm 200$ years (Pierson and others, 1966); Meyer Reubin, in Friedman, 1977), with an older age $(2,054+230$ years $)$ obtained many years ago by Libby $(195 \overline{2})$. The final event was the eruption of the Big Obsidian flow and the domal protrusion that marks its vent. Slight collapse occurred over a one-half-mile-wide area around the vent before the flow was erupted. The flow extends northward from near the outer caldera wall to near the paved road in the caldera and, in its northern part, partly filled an older pumice ring (stop 8, road $\log$ ).

Considering the long time over which eruptions took place on Newberry, the volcano should be considered dormant but capable of future eruptions even though about $1,300-1,400$ years have transpired since the last eruptions. Newberry is ideally suited for those who wish to see diverse volcanic features. Its rocks range widely in composition, and examples from it could be used to illustrate a nearly complete atlas of the types of products of volcanism.

\section{LIST OF REFERENCES}

Beyer, R. L., 1973, Magma differentiation at Newberry crater in central Oregon: Eugene, University of Oregon, Ph. D. thesis, $84 \mathrm{p}$.

Chitwood, L. A., Jenson, R. A., and Groh, E. A., 1977, The age of Lava Butte: The Ore Bin, v. 39, no. 10 , p. 157-164.

Friedman, Irving, 1977, Hydration dating of volcanism at Newberry Crater, Oregon: U.S.
Geological Survey Journal of Research, v. 5, no. 3, p. 337-342.

Greeley, Ronald, 1971, Geology of selected lava tubes in the Bend area, Oregon: Oregon Department of Geology and Mineral Industries Bullet in $71,47 \mathrm{p}$.

Greene, R. C., Walker, G. W., and Corcoran, R. E., 1972, Geologic map of the Burns quadrangle, Oregon: U.S. Geological Survey Miscellaneous Geologic Investigations Map I-680, scale $1: 250,000$.

Higgins, M. W., 1969, Airfall ash and pumice lapilli deposits from Central Pumice cone, Newberry caldera, Oregon, in Geological Survey Research 1969: U.S. Geological Survey Professional Paper 650-D, p. D26-D 32 .

1973, Petrology of Newberry volcano, central Oregon: Geological Society of America Bulletin, v. 84, p. $455-488$.

Higgins, M. W., and Waters, A. C., 1968, Newberry caldera field trip, in Andesite Conference Guidebook; Oregon Department of Geology and Mineral Industries Bulletin, p. 59-77.

Laidley, R. A., and McKay, D. S., 1971, Geochemical examination of obsidians from Newberry caldera, Oregon: Contributions to Mineralogy and Petrology, v. 30, p. 336-342.

Libby, W. F., 1952, Chicago radiocarbon dates III: Science, v. 161, p. 673-681.

MacLeod, N. S., Walker, G. W., and McKee, E. H., 1975, Geothermal significance of eastward increase in age of upper Cenozoic rhyolitic domes in southeast Oregon: Second United Nations Symposium on the Development and Use of Geothermal Resources, Proceedings, v. 1, p. 465474.

McKee, E. H., MacLeod, N. S., and Walker, G. W., 1976, Potassium-argon ages of Late Cenozoic silicic volcanic rocks, southeast Oregon: Isochron/West, no. 15, p. 37-41.

Peterson, N. V., and Groh, E. A., 1969, The ages of some Holocene volcanic eruptions in the Newberry volcano area, Oregon: The Ore Bin, v. 31, p. 73-87.

1976, Geology and mineral resources of Deschutes County, Oregon: Oregon Department of Geology and Mineral Industries Bulletin 89, 66 p.

Pierson, F. J., Jr., Davis, E. M., and Tamers, M. A., 1966, University of Texas radiocarbon dates IV: Radiocarbon, v. 8, p. 453-466.

Russe11, I. C., 1905, Preliminary report on the geology and water resources of central Oregon: U.S. Geological Survey Bulletin 252, 138 p.

Sherrod, D. R., and MacLeod, N. S., 1979, The last eruptions at Newberry volcano, central Oregon [abs.]: Geological Society of America, Abstracts with Programs, v. 11, no. 3, p. 127.

Walker, G. W., 1974, Some implications of Late Cenozoic volcanism to geothermal potential in the High Lava Plains of south-central Oregon: The Ore Bin, v. 36, no. 7, p. 109-119.

Walker, G. W., Peterson, N. V., and Greene, R. C., 1967, Reconnaissance geologic map of the east half of the Crescent quadrangle, Lake, Deschutes, and Crook Counties, Oregon: U.S. Geological Survey Miscellaneous Geologic Investigations Map I-493, scale $1: 250,000$.

Williams, Howel1, 1935, Newberry volcano of central Oregon: Geological Society of America Bulletin, v. 46, p. 253-304.

1957, A geologic map of the Bend quadrangle, Oregon, and a reconnaissance geologic map of the central portion of the High Cascade Mountains: Oregon Department of Geology and Mineral Industries Map, scales $1: 125,000$ and $1: 250,000$. 
ROADLOG FOR

\title{
NEWBERRY VOLCANO, OREGON
}

\author{
Norman S. MacLeod, David R. Sherrod \\ U.S. Geological Survey, Menlo Park, California 94025
}

Lawrence A. Chitwood, U.S. Forest Service, Bend, Oregon 97701

and

Edwin H. McKee, U.S. Geological Survey, Menlo Park, California 94025

The route of this field trip (figs. 1, 2) leads southward from Bend across the basalt and basaltic-andesite flows of Newberry's northwest flank and eastward up the west flank where pyroclastic units are visited. Several stops in the caldera, including an overview stop provided by Paulina Peak, show the diversity of caldera rock units. The trip continues down the east and northeast flanks with stops to see several ash-flow tuffs and returns to Bend across the apron of basalt flows that extend far north of Newberry. Total mileage of the trip is about $118 \mathrm{mfles}$, all on paved or improved gravel roads that are readily traversed by passenger cars or buses. Mileages are approximate, all turns and stops are underlined, and old and new (in parenthesis) U.S. Forest Service road numbers are shown where appropriate. The ${ }^{14} \mathrm{C}$ ages of young basalt flows are mostly from Peterson and Groh (1969).

Miles

0.0 Junction U.S. Highways 97 and 20 in Bend, Oregon. Elevation 3,630. Head south on U.S. Highway 97 .

$(0.7)$

0.7 Diktytaxitic olivine-phyric high-alumina basalts exposed in railroad underpass and intermittently for the next 11 miles to south are typical of Newberry's lower flank flows. Northwest-trending faults that extend in a broad zone through the Bend area offset the flows. A typical analysis of a lower flank flow is shown in table 1 , column 1 .

3.9 Road 1821 (18) leads eastward to interesting lava tubes (Boyd Cave, 9 miles; Skeleton Cave, 12 miles; Wind Cave, 13 miles; and Arnold Ice Cave, 13 miles)

Ash-flow tuff exposed on east side of U.S. 97 near draw. Ash flow is widespread around the Bend area and was derived from the Cascade Range west of Bend. Outcrops and float near railroad west of road show a wide range in pumice composition.

10.0 Roadcuts expose cinder plume that extends northeast from Lava Butte. Charcoal from base of cinders here yielded ${ }^{14} \mathrm{C}$ age of $6,160 \pm 65$ years (Chitwood and others, 1977).

$(0.7)$

10.7

Northwest-trending fault exposed on east side of highway offsets diktytaxitic olfvine basalt. Note young "Gas Line" basaltic-andesite flow south of fault $\left({ }^{14} \mathrm{C}\right.$ age $5,800 \pm 150$ to $6,160 \pm 65$ years, (S. W. Robinson, written commun., 1978). 
13.0 STOP 1 at top of Lava Butte (elevation 4,970 ft). The basaltic andesite flow derived from Lava Butte extends northward more than 5 miles and westward 3 miles to the Deschutes River. A chemical analysis of the flow is shown in table 1, column 2. It is one of many basaltic andesite flows on Newberry that have ${ }^{14} \mathrm{C}$ ages of about 6,100 years. Several, including the "Gas Line" and Mokst Butte flows, can be seen from this stop. Note also the many cinder cones on the north and northwest flank, an area formed mostly of basalt and basaltic-andesite flows and associated vents, most of which are younger than the pyroclastic units that will be visited on the east and west flanks. A panorama of the Cascade Range, particularly of the Bachelor Butte, Broken Top, and Three Sisters area, can be viewed from here. South of Lava Butte, Pleistocene (and Pliocene?) lacustrine and fluvial sediments of the La Pine basin lie between Newberry Volcano and the Cascade Range. Return to Highway 97.

14.8 Turn south on U.S. Highway 97.

16.0 Road on east leads to Lava River Cave, $1 / 4 \mathrm{mile}$ from highway. The mile-long lava tube is now a state park and is open to the public (lanterns can be rented at the entrance).

18.4 Sun River Junction. Road on east goes by Camp Abbot Cinder Pit ( $3 / 4 \mathrm{mile}$ ) to Lava Cast Forest (9-1/2 miles). The cinder pit coptains brilliant blue, green, gold, and red cinders. Lava Cast Forest flow $\left({ }^{14} \mathrm{C}\right.$ ages, $6,380 \pm 130$ and $6,150 \pm 210$ years) contains numerous well-developed tree casts. A mile-long paved trail leads past many casts. Other young flows accessible by this road include Forest Road $(5,960 \pm 100$ years $)$, Mokst Butte, and Lava Cascade $(5,800 \pm 100$ years $)$.

$(2.4)$

20.8

Fall River Junction. Road on east leads to Sugarpine Butte flow $\left({ }^{14} \mathrm{C}\right.$ age, $5,870 \pm 100$ years).

24.0 Cross old logging railroad grade that went to the now abandoned town of Shevlin. Many hundreds of miles of roads on Newberry are on or along old railroads developed about 50 years ago when logging in the area was at a peak.

$(0.6)$

24.6 Approximate boundary of Newberry lavas and sediments of the La Pine basin. Gravel in this area is mostly composed of black lapilli with rhyolitic inclusions like those that form the lapilli tuff at stop 2 . These can be seen in this area in several pits, including the garbage dump (Southwest Landfili), east of the highway.

$(1.2)$

25.8 La Pine State Recreation Area junction. To west 5 miles are excellent exposures of fluvial and lacustrine sediments, including diatomite, along the scenic Deschutes River.

$(1.1)$

26.9 Turn east (elevation 4,205 ft) on Paulina Lake Road, U.S. Forest Service Road $2129(21)$. Road crosses Mazama ash-covered alluvial sediments. 
29.9 Outcrops of Newberry lava flows near road. Farther along the road these flows are locally buried by lapilli tuffs like those at stop 2 as well as by gravel.

$(0.5)$

30.4

(3.2)

33.6

$(2.9)$

36.5

$(0.4)$

36.9

$(0.6)$

37.5 Contact of lapilli tuff and cinder cones. These vents probably fed flows exposed farther down the road that underlie the lapilli tuff. Cinder cones are buried on their east (caldera) sides by ash-flow tuffs like at stop 4 .

$(0.7)$

38.2 Float of andesitic ash-flow tuff along road.

$(0.1)$

38.3

$(0.1)$

38.4

At this site on September 19, 1979, The Cascade Rattlesnake Award was presented to J. P. Lockwood before a cheering audience of 80 geologists.

Road 2045 provides access to three rhyolite domes at and near McKay Butte (KAr age, $0.6 \pm .1 \mathrm{~m} \cdot \mathrm{y}$. , may be reversely polarized).

STOP 2 (elevation 5,420) at large scree-covered slope on north side of road. The lapilli tuff at this stop is one of the most widespread tephra units on Newberry's flanks. The unit is rarely exposed but the lapilli in it are distinctive so that float from the unit can be recognized. On the west flank the lapilli tuff covers an area of about 30 square miles, with basalt flows cropping out locally beneath 1t; higher on the west flank it is overlain by ash-flow tuffs like those at stop 4. The lapilli tuff on the northeast flank occurs higher in the section than the ash-flow tuffs to be seen at stops 12 , 13, and 14. It is also a major constituent of gravel deposits on all sides of the volcano. The lapilli tuff is deeply eroded but locally exceeds $200 \mathrm{ft}$ thick, and original volume was probably 5 to 10 cubic miles. It consists of dark gray to black lapilli, and less common blocks and bombs, in an ashy lithic-rich matrix. Sorting is very poor and in observed outcrops the unit is massive. Most lapilli are finely vesicular to frothy, have cauliflowerlike surfaces, and contain small, generally angular, rhyolite, and more mafic inclusions. The normal polarization of the lapilli and matrix suggests that they were above the Curie point temperature when deposited. The poor sorting and massiveness of the unit suggest that it was a hot pyroclastic flow or flows. The large volume of the unit permits speculation that its eruption may have been accompanied by caldera collapse. Continue upslope on road.

Upper snowmobile parking lot. Rhyolite domes or flows occur north and south of here.

\section{Turn south to U.S. Forest Service pit F-17, also known as "Mixture Butte."}

STOP 3 (elevation 5,960 ft) at "Mixture Butte," a cinder cone with rhyolite and pumice inclusions. The pit is on the north side of a horseshoe-shaped cone that is buried by ash-flow tuffs on its east (caldera) side. Rhyolite and pumice, as well as basalt and andesite, occur as inclusions in the cinders and bombs and as accidental fragments in the deposits. Some inclusions have been fused and have flowed. The pumice, in blocks to more than $2 \mathrm{ft}$ wide, commonly shows bands of different color and probably composition. A mile-long rhyolite dome crops out about 1 mile to the southwest, contains phenocrysts similar to those in the pumice and rhyolite inclusions and may extend at depth 
beneath the cinder cone. Possibly the pumice is derived from a buried pumice ring associated with the dome. Many cinder cones and flows on the upper flank of the volcano contain rhyolite inclusions. Rhyolite domes and flows crop out in many places and may be much more extensive at depth. Return to Paulina Lake Road.

(0.1)

38.5

$(0.6)$

39.1

$(0.9)$

40.0

$(0.2)$

40.2

Turn east on Paulina Lake Road. Area between here and stop 4 is almost entirely underlain by andesitic ash-flow tuffs; found as large slabs of float and less commonly as outcrop.

Turn south on Road 2131 (2121) (elevation 6,020 ft).

West of road is eroded cinder cone with associated flows that are partly buried by ash-flow tuff.

STOP 4 (elevation 5950). Park at road intersection and walk $500 \mathrm{ft}$ eastward along small side road to exposures of ash-flow tuff along side of ravine. Andesitic ash-flow tuffs crop out over a 5-square-mile area of the upper west flank of the volcano and grade near the rim to pyroclastic deposits that have characteristics more nearly like agglutinate deposits, as at stop 5. The unit consists of ash flows as little as $1 \mathrm{ft}$ thick to as much as $30 \mathrm{ft}$. The ash flows are pumiceous, rich in lithic fragments and crystals, and reddish brown. Even thin units commonly show welding. At many localities collapsed pumices are brilliant blue and green. The ash flows are very near vent deposits, perhaps from a ring fracture near the west side of the caldera, and have relatively small volume. Ash-flow tuffs similar to these occur at scattered localities on the upper east flank. Return to Paulina Lake Road.

$(1.1)$

41.3

Turn east on Paulina Lake Road:

$(1.0)$

42.3 Turn north into Paulina Falls parking lot.

$(0.1)$

42.4 STOP 5 Paulina Falls (elevation 6,240 ft). Paulina Creek drains Paulina Lake, less than $1 / 2$ mile to the east. The indurated rocks that form the cliffs of the falls are agglutinated andesitic pyroclastic deposits formed of many thin to thick units. Similar rocks occur along the caldera wall for about $1-1 / 2$ miles north of the creek. They grade down the creek into ash flows like those at stop 4 and represent very near vent deposits, perhaps from a ring fracture bordering the west side of the caldera. Most of the deposit is probably co-ignimbrite $1 \mathrm{ag}$, many units being entirely fall, others stubby agglutinated pyroclastic flows. A chemical analysis for this locality is shown in table 1 , column 3. The less indurated rocks below the cliffs are formed of poorly sorted and rudely bedded ash, lapilli, and blocks with abundant accidental lithic fragments. Some beds low in the section contain accretionary and mudarmored lapilli. The contact between the lower and upper unit is gradational. Probably the eruptions first deposited relatively cold material, perhaps from phreatic eruptions, and temperatures increased to the point where all fragments were agglutinated at time of deposition. Lapilli tuffs like those at stop 2 occur at creek level only a few hundred feet downstream from the falls. Return to Paulina Lake Road.

$(0.1)$

42.5 Continue east on Paulina Lake Road.

$(0.3)$

42.8 Turn south on road 2160 (500) to Paulina Peak. 

rhyolite dome.

(0.6)

44.7

(1.1)

45.8

(1.3)

47.1

View northward of gently sloping upper west flank formed mostly of ash-flow tuffs like at stop 4. Note rhyolite domes at and near McKay Butte (N. $60^{\circ} \mathrm{W}$., $5-1 / 2$ miles). View of numerous cinder cones on south flank and long narrow Surveyor flow
$\left({ }^{14} \mathrm{C}\right.$ age $6080 \pm 100$ years $)$. STOP 6 Paulina Peak (elevation 7,984 ft). Before looking at the caldera, walk to peak for view southward. Note fault-bounded Walker Mountain (S. $42^{\circ}$ W., 35 miles). Faults of the Walker Rim zone extend to Newberry's lower south flank. Some of the older rocks, such as the reversely polarized dacite flows on Indian-Amota Butte (S. $30^{\circ} \mathrm{E}$, 11 miles), are offset several hundred feet by northeast-trending faults; faults that cut the nearby basalt flows have vertical offsets of less than $100 \mathrm{ft}$ and the faults disappear upslope below younger flows. Other distant features include:

(1) Bald Mountain (S. $12^{\circ}$ W., 28 miles), a rhyolite dome on the south side of a poorly preserved 4- or 5-million-year-old caldera with widespread ash-flow tuffs that crop out from Fort Rock Valley east of it, to Walker Mountain.

(2) Cascade Range. From south to north on a clear day you can see Mount Shasta, Mount Scott, Crater Lake, Mount Thielson, Diamond Peak, The Three Sisters, and nearby Bachelor Butte and Broken Top, Mount Washington, Three Fingered Jack, Mount Jefferson, Mount Hood, and Mount Adams.

(3) Fort Rock Valley southeast of Newberry with numerous palagonite tuff rings, cones, and maars. Included in these are Fort Rock in the middle of the valley, and beyond it about 39 miles from here is Table Rock, the site of a field trip by Heiken and Fisher (this vol.).

(4) To the east are China Hat (N. $85^{\circ}$ E., 11 miles) and East Butte next to it. They are 0.8 - and $0.9-\mathrm{m} \cdot \mathrm{y} \cdot-\mathrm{old}$ rhyolite domes on the west end of the belt of age transgressive rhyolite vents. Note the 5-m.y.-old rhyolites of the Glass Buttes dome complex on the skyline (S. $80^{\circ}$ E., 60 miles). The High Lava Plains, a broad zone of Miocene to Quaternary basalts in addition to rhyolite domes and flows, extends from Newberry beyond Glass Butte.

Now walk to the north along and beyond the fence bordering the cliffs of Paulina Peak to a viewpoint about $50 \mathrm{ft}$ below the elevation of the parking 1ot. Please use caution in this area--the cliffs are $500 \mathrm{ft}$ high. The generallized geologic map of the caldera (fig. 2) should be referred to for identifying features. From this location you can see the inner and outer (near pumice flats) walls of the south side of the caldera. The caldera wall rocks have been described by Higgins and Waters (1968) and Higgins (1973). The south wall near the Big Obsidian flow consists of platy rhyolite, basaltic andesite flows, scoria and cinder deposits, and an overlying obsidian flow. At the west end of the wall exposures is a thick sequence of near-vent pumice and ash deposits that have been fused near their contact with the obsidian flow. The north and east caldera walls contain rhyolite and basaltic andesite flows and pyroclastic rocks, as well as palagonite tuff; the east wall also contains near vent welded rhyolitic pumice deposits. Basaltic vents and flows occur on the north wall near Paulina Lake (Red Slide) and East Lake (East Lake fissure, Sheeps Rump), and a long fissure vent occurs near the top of the east wall. All of these vents and associated flows are pre-Mazama ash in age, 
except the East Lake Fissure. It is the southernmost vent of the northwest rift zone sequence of basalt flows and vents, about 6,100 years old, and contains abundant inclusions of obsidian, rhyolite, etc. (Higgins and Waters, 1970).

Young rhyolitic flows, pumice cones, rings, and other tephra deposits are widespread around East Lake. Hydration-rind dating by Friedman (1977) indicates that the East Lake obsidian flows are about 3,500 years old and that many of the other obsidian flows and pumice cones (Interlake flow, Gamehut flow, Central Pumice cone) are 4,500 to 6,700 years old.

The youngest period of volcanism was associated with the vent for the Big Obsidian flow. Eruptions began with a widespread pumice fall that now covers much of Newberry's east flank and which will be seen later at stop 11 . Higgins (1969) obtained carbon from beneath the fall that has a ${ }^{14} \mathrm{C}$ age of $1,720 \pm 250$ years, and we found carbon at another locality with an age of $1,550 \pm 120$ years (S. W. Robinson, written commun., 1978). Isopachs of the pumice fall clearly show that it was erupted from at or very near the vent for the Big Obsidian flow (Sherrod and MacLeod, 1979). Later eruptions produced the Paulina Lake ash flow (stop 7) 1,300 to 1,400 years ago. The final event was the eruption of the Big Obsidian flow and the domal protrusion that marks its vent. Slight collapse occurred over a $1 / 2-m i l e-w i d e$ area around the vent before the flow was erupted.

Paulina Peak dome extends about 3 miles southwest down the flank and is about 1 mile wide. It is marked by large rills parallel to its axis that formed during expansion of the surface of the dome much as cracks form on french bread. The age of the dome is not yet known, but an obsidian flow that occurs on axis with the dome farther down the flank is $0.4 \mathrm{~m} \cdot \mathrm{y} \cdot$ (E. H. McKee, unpub. data, 1979), and Paulina Peak dome may be similar in age. An analysis of rhyolite from the Paulina Peak dome is shown in table 1 .

Return to Paulina Lake Road.

$(4 \cdot 3)$

51.4 Turn east on Paulina Lake Road.

$(0.1)$

51.5 Paulina Lake campground provides a convenient lunch stop.

51.8 Roadcuts expose Mazama ash covered by a few inches of fine ash from Newberry eruptions. Holes dug through the Mazama ash show that it overlies sand and gravel deposits.

52.3 Road traverses south side of two rhyolite domes, overlain by Mazama ash and bordered on south by landslide deposits.

$(0.3)$

52.6 Roadcut exposes rudely bedded ash and pumice deposits, perhaps the remnant of a pumice ring associated with the rhyolite domes.

$(0.1)$

52.7 Westernlimit of Paulina Lake ash flow.

$(0.2)$

52.9 STOP 7 Paulina Lake ash flow. Concrete boxes on south side of road preserve collecting site for carbon in ash flow. Originally dated by Libby (1952) as $2,054+230{ }^{14} \mathrm{C}$ years, subsequent dates indicate a younger age $(1,270 \pm 60$ years, Pierson and others, 1966; and 1,390+200, Meyer Reubin, in Friedman, 1977). The ash flow extends from the Big Obsidian flow to the shore of Paulina Lake. Ridges and furrows on the ash flow are apparently primary features, and 
their orientation suggests that the vent is located beneath the southern part of the Big Obsidian flow (Higgins, 1973). Although pumice is generally abundant, the ash flow in many places is composed almost entirely of ash. The absence of collapse and welding indicates the deposit had only a moderate temperature when emplaced, but sufficient for oxidation to give the deposit a slightly pinkish color. Continue eastward on road over ash flow.

$(0.4)$

$(0.4)$

53.7

$(0.1)$

53.8

$(0.1)$

53.9

$(0.4)$

54.3

$(0.5)$

54.8

(0.5)

55.3

$(0.3)$

55.6 Turn left to East Lake Campground and walk eastward along shore.

Road on north leads to Little Crater Campground and interesting exposures along shoreline of palagonite tuff and silicified pumiceous, fossiliferous, lake deposits.

Turn Right to parking lot next to Big Obsidian flow.

STOP 8 (elevation 6,370 ft) Big Obsidian flow. Before walking to the flow, note that the pinkish Paulina Lake ash flow overlies weathered pumice deposits of a pumice ring on the east side of the parking lot. Lost Lake pumice ring is partly covered by the Big Obsidian flow, but its northern part can be seen from the trail ascending the obsidian flow. The trail provides interesting exposures of flow-banded obsidian, pumiceous obsidian, brown streaky obsidian that was formerly pumiceous before it collapsed, and various features indicating the flow behaved in both plastic and brittle manner during its emplacement. Laidley and McKay (1971) did extensive analytical work on the Big Obsidian flow and showed that is is essentially uniform in composition. Their average of 66 chemical analyses is shown in table 1, column 5 . Return to parking lot and to main road; note exposures of palagonite tuff of Little Crater north of road.

Continue eastward on paved road.

Road on south leads to drill site of U.S. Geological Survey core hole. Note Central Pumice cone to north.

Game Hut obsidian flow is exposed on north side of road.

STOP 9 (elevation $6,460 \mathrm{ft}$ ). Pumiceous tephra deposits of the East Lake area. Roadcuts expose massive to rudely bedded pumice and ash with large accidental blocks overlain by mud-armored pumice, accretionary lapilli, pumice, and ash beds. Bomb sags occur in the upper bedded part and indicate that the beds were probably wet and cohesive. A hole dug vertically through the deposits indicates that they are about $14 \mathrm{ft}$ thick and overlie Mazama ash, which rests on obsidian. Tephra deposits, similar to the exposures here, occur over most of the eastern part of the caldera except where buried by younger units (East Lake obsidian flows, etc.). The vent or vents for the deposit are not known, and conceivably may lie in East Lake. The obsidian that underlies the deposit is part of an extensive obsidian flow that, mostly on the basis of topographic expression, probably extends to the south (inner) wall of the caldera, its vent apparently being an obsidian dome near the wall. Continue eastward along road. 
55.7 STOP 10 (elevation 6,382 ft). Palagonite tuff of East Lake. The palagonite tuff is overlain by Mazama ash and by pumiceous tephra deposits like those at stop 9. Many of the beds in the palagonite tuff are formed of mud-armored lapilli and accretionary lapilli, presumably indicating that the exposed part of the unit was deposited above water. Note also several bomb sags. About halfway along the shoreline exposures is a contact between two palagonite tuff units; the western unit is younger and locally is plastered vertically on the eastern unit. The eastern palagonite tuff contains very abundant and large accidental blocks of palagonite tuff that are more thoroughly palagonitized than is the tuff they occur in. From the shore you can look westward to see the Central Pumice cone, northward at the East Lake fissure, and northeastward at the Sheeps Rump and the obsidian flow that extends to the northeastern shoreline. Return to the main road.

$(0.1)$

55.8

$(0.6)$

56.4 Hot springs occur along shore near headland formed of palagonite tuff. Temperatures as high as $80^{\circ} \mathrm{C}$ have been measured, but the hot spring water is diluted by lake water.

Turn east on paved road.

Turn east on gravel road, U.S. Forest Service Road 2129 (21). Note exposures of andesite near road intersection. This flow has been traced southeastward to the fissure that occurs at the top of the east wall of the caldera. This fissure contains rocks of highly variable composition and phenocryst content, as does the flow. Cinders, bombs, and spatter associated with the fissure can be seen from several places along the road.

\section{Pumiceous tephra deposits exposed in roadcuts are similar to those seen at stop 9.}

\begin{abstract}
Road here crosses over andesite flow, but it is buried by Mazama ash and pumiceous tephra like at stop 9.
\end{abstract}

Pumice fall derived from vent for Big Obsidian flow forms a thin surficial unit that thickens as we progress up the road toward the south.

Top of east rim of caldera (elevation $7,008 \mathrm{ft}$ ) covered by pumice fall about 8 ft thick.

STOP 11 (elevation 7,010). Pumice fall derived from vent for Big Obsidian flow. The fall is exposed in a large hole dug in roadcut on north side of road. The fall is about $9-1 / 2$ ft thick here, but the axis of the fall is about $1 / 2$ mile to the south. ${ }^{14} \mathrm{C}$ ages of the fall are $1,720 \pm 250$ (Higgins, 1969 ) and $1,550 \pm 120$ (S. W. Robinson written commun., 1978) years. One hundred and fifty holes dug through the pumfce fall (and most not in roadcuts as at this site) show that it forms a very narrow plume (at the 10-in. isopach it is 6 miles wide by 40 miles long) oriented $\mathrm{N}$. $80^{\circ} \mathrm{E}$., from the Big Obsidian flow vent. The orientation of the plume is the same as the current prevailing wind as indicated by deformed trees on higher ridges and buttes (for instance, on The Dome, a cinder cone immediately south of here). Pumfce lapilli and blocks constitute most of the unit, but accidental fragments of basalt, rhyolite, obsidian, etc., are common. Ash forms a conspicuously small part of the unit. Sizes of the pumice and lithic fragments decrease regularly eastward. 
Within about 6 miles of the vent the upper part of the unit contains a few thin ash beds, generally 1 in. or less thick. They may be products of small groundsurges, ash washed from the eruption cloud, or decline of eruption pulses. Continue east.

$(0.9)$

60.0

$(2.0)$

62.0

(4.7)

66.7

$(0.9)$

67.6

(1.5)

69.1

(0.8)

69.9

(0.5)

70.4

$(0.1)$

70.5

(3.4)

73.9

$(0.4)$

74.3

(4.4)

78.7

(0.9)

79.6

View back to west of The Dome, a cinder cone partly covered by pumice fall. Road down east flank traverses the pumice fall. At the intersection of the road with Road 1821 (18) the pumice fall is about $3.3 \mathrm{ft}$ thick.

Note Red Hill, a young cinder cone to north; pumice fall once covered it but now is eroded.

Turn south on Road 1821 (18) (elevation about 5,250 ft) which passes on west side of China Hat, an $0.8-\mathrm{m} \cdot \mathrm{y} \cdot-\mathrm{old}$ rhyolite dome.

Road intersection (Road 2228), keep to left on 1821 (18).

Note young basalt flow on west. It is overlain by Mazama ash and Newberry pumice fall.

Ash-flow tuff crops out beside road.

Section line 23-26 marker on tree.

STOP 12. Ash-flow tuff (elevation about 5,070 ft). Walk eastward on smal1 dirt road to outcrops of ash-flow tuff. Note the exposures in roadcuts above the small cliffs. This ash flow crops out over a north-south distance of 5 miles but is overlain in places by alluvial deposits and basalt flows. It is buried on the west by similar rocks. The base of the ash flow is not exposed and the top is eroded, but it occurs in outcrops as much as $25 \mathrm{ft}$ high. The ash flow is dark colored and contains abundant gray to black pumice in an ashy lithic-rich matrix. This ash flow may correlate with an ash flow that crops out locally for a distance of about 10 miles northward from this locality, and higher in the section than the ash flows to be visited at stops 13 and 14 . Turn around and go back (northward) on Road 1821 (18).

Cut on east side of road exposes pumice fall over Mazama ash. Old railroad grade to east leads to road on west side of China Hat where pumice falls and ash flows are plastered on the side of the rhyolite dome.

Road 2129 (21) on west, continue northward on 1821 (18).

Road on left leads to site of Brooks-Scanlon Camp No. 3, used in the heyday of logging in the $1930^{\prime} \mathrm{s}$. Exposure of alluvium on left. The alluvium extends up the slope to the caldera rim.

Ravine. South of the ravine are exposures of basalt with local windows of rhyolitic ash-flow tuff. North of draw rhyolitic ash-flow tuff and a thin veneer of gravel form the surficial rocks to and beyond the next turn at 82.2 miles. 
Turn west on Road 2113 (1835) (elevation 4,885 ft) Road is along broad ridge covered by gravel deposits that overlie ash-flow tuffs.

STOP 13. Ash-flow tuff (elevation $5,170 \mathrm{ft}$ ). Park in wide area on south side of road and walk southward to outcrops along side of ravine. This darkcolored ash-flow tuff, characterized by porphyritic obsidian as a common accidental lithic constituent, is formed of black to dark-gray porphyritic pumice in an ashy lithic- and crystal-rich matrix. It crops out along ravine walls at this general elevation for a distance of about 4 miles, beyond which it is buried by basalt flows. Farther upslope it is buried beneath alluvial deposits and basalt flows. The unit is similar to the ash flow visited at stop 12 but has a different lithic component and is much more crystal rich. Ash flows, like those at stop 12, occur further north; some occur plastered on the sides of cinder cones (e.g., Orphan Butte). A thick sequence of lapilli tuff, identical to that at stop 2 on the west flank, occurs about 2 miles northeast of this locality and higher in the section. Turn around and return eastward on road 2113 (1835).

$(2.1)$

86.4

$(1.5)$

87.9

1.2)

89.1

$(0.7)$

89.8

$(0.6)$

90.4

Continue on road 2113 across road 1821 (18). Road traverses area of rhyolitic ash-flow tuff like at stop 14, overlain by thin gravel veneer. Exposures of ash-flow tuff can be seen along many small ravines north and south of road.

Kipuka of basalt projects through rhyolitic ash-flow tuff south of road.

Turn north on Road 2013 (13) (elevation 4,665).

Basalt flow on east was derived from a vent east of China Hat.

STOP 14 (elevation 4,540 ft). Teepee Draw ash flow. Walk west from the border of the National Forest to outcrops of ash-flow tuff on sides of ravines. Note that basalt flows crop out on east side of nearest ravine and on west side of the far ravine immediately north of the ash-flow tuff. This rhyolitic ash-flow tuff covers a large area on the lower eastern and northeastern flank and is buried to the northwest and south by basalt flows. Toward the caldera gravel on the surface of the ash flow thickens to the point where float and outcrops of the ash flow can no longer be found. This is the oldest known tephra unit on the volcano. Plagioclase separated from pumice in it yielded an age of $0.7 \mathrm{~m} \cdot \mathrm{y}$. (McKee and others, 1976), but unfortunately a high atmospheric argon content resulted in an uncertainty as large as the age. The ash flow and overlying units are normally polarized. At this locality the lower part of the ash flow is uncollapsed and consists of large pumices in an ashy lithic- and crystal-rich matrix. The pumices show progressive collapse upward and the top of the unit is welded. Note the scattered fossil fumaroles in the cliff face. Toward the caldera the unit becomes progressively more densely welded. The base of the unit is exposed only where kipukas of basalt project through it and the top is eroded. Along some ravines, however, the unit is more than $70 \mathrm{ft}$ thick with the base not exposed. This ash-flow tuff probably was associated with an early, if not the earliest, period of caldera collapse. It and the ash-flow tuff at stop 13 are older than the tephra deposits of the west flank and may occur at depth entirely around the volcano. Look to the east to see Pine Mountain, a complex 
of flows and intrusions mostly of dacitic to rhyolitic composition that are about $21 \mathrm{~m} \cdot \mathrm{y}$. old and that probably correlate in part with the John Day Formation. Continue north on road.

$(0.9)$

91.3 Turn northwestward on road 2043 (23).

93.3 Outcrop of ash-flow tuff west of road.

$(0.4)$

93.7 Outcrop of ash-flow tuff on subdued hill east of road 1s the most northeasterly known outcrop. Eroded alluvial fan deposits derived from Newberry and Pine Mountain cover the distal part of the ash flow and it is also buried on the west by basalt flows from Newberry.

$(1.1)$

94.8 To the west is Horse Ridge, a highly faulted sequence of older basalt flows and near-vent deposits. The faults are part of the Brothers fault zone.

$(2.5)$

97.3 Junction with U.S. Highway 20. Turn west.

$(1.7)$

99.0 Viewpoint. Dry river canyon is $800 \mathrm{ft}$ wide and $300 \mathrm{ft}$ deep at this point. For next 0.8 mile roadcuts and canyon walls expose lavas of Horse Ridge. The basalt flows, with interbedded tuff and breccia, have yielded a 7-m.y. K-Ar age.

101.0 U.S. Highway 20 from here to Bend crosses diktytaxitic high-alumina basalts derived from Newberry that cover much of the low-lying region to the north.

$(16.4)$

117.4 Road on north leads to Pilot Butte. Although young in appearance, this cinder cone is probably many hundreds of thousands years old, as it is locally overlain by an early Pleistocene pumice fall.

$(0.7)$

118.1 End of trip at Junction of U.S. Highways 20 and 97 in Bend, Oreg. 


\section{GEOLOGIC SUMMARY}

The field trip through the High Lava Plains province of central and south-central Oregon (fig. 1) provides a reconnaissance overview of the Cenozoic volcanic geology along the Brothers fault zone from Bend to Harney Basin, the site of vents for several ash-flow tuffs that cover thousands of square kilometers of southeast Oregon and have volumes of hundreds of cubic kilometers. Most of this area has been mapped only in reconnaissance (Walker and others, 1967; Greene and others, 1972), and many interesting details of the geology have yet to be studied. From east to west the geologic record generally progresses forward in time with some of the youngest volcanic rocks at the west (or Bend) end of the trip and the oldest at the east end in and near Harney Basin. This description is an oversimplification with respect to the basaltic rocks, but the silicic rocks show a well-defined age progression in silicic volcanism described by Walker (1974) and MacLeod, and others, (1976).

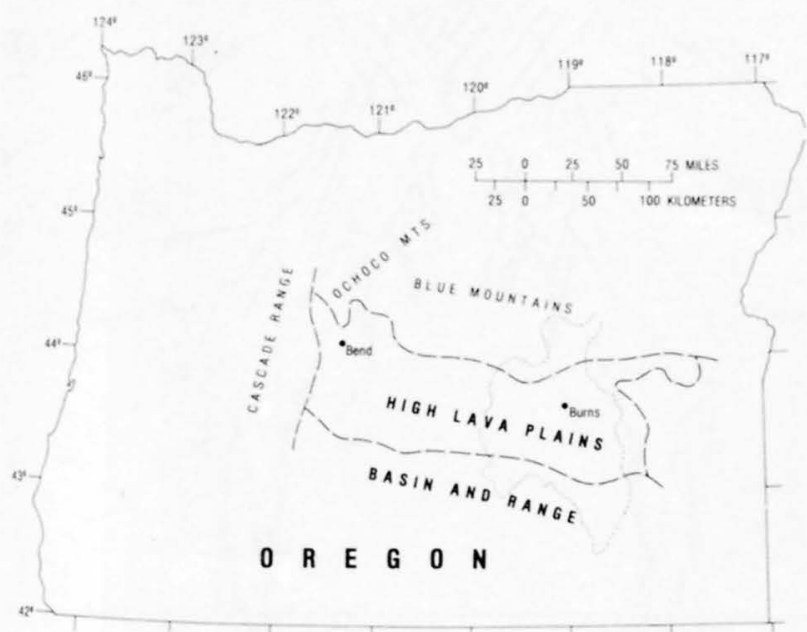

Figure 1.--Index map of Oregon showing the High Lava Plains and approximate outline of Harney Basin (dotted line).

The High Lava Plains province is a middle and late Cenozoic volcanic upland nearly $250 \mathrm{~km}$ long and about $80 \mathrm{~km}$ wide that extends south-eastward from the Cascade Range to the eastern margin of the Harney Basin. Structurally the province is dominated by a west-northwest-trending zone of en echelon normal faults (fig. 2A, B, and C), generally called the Brothers fault zone, that can be traced for most of the length of the province and perhaps well beyond the province boundaries. Eruptive centers for both basaltic and rhyolitic volcanic rocks are concentrated in the zone of faults and in some nearby subsidiary fault zones. A belt of late Cenozoic basaltic flows, extending from the Bend area nearly to the
Idaho border (Walker, 1977), obscures much of the older Cenozoic geology along the Brothers fault zone.

The High Lava Plains are contiguous with and gradational into the Basin and Range province to the south, and many late Cenozoic volcanic rocks and fault structures are common to both provinces. For instance, some of the larger north- and northeast-trending faults, characteristic of the Basin and Range, appear to change to a northwest trend and blend into the Brothers fault zone (Walker, 1977). A comparatively sharp boundary separates the High Lava Plains from the Blue Mountain province to the north, where older Cenozoic and pre-Cenozoic rocks have been brought to the surface in the Blue Mountain-Ochoco Mountains uplift.

Older Cenozoic volcanic and tuffaceous sedimentary rocks are exposed along the northern margin of the High Lava Plains and in kipukas (inliers), such as Pine Mountain, and include parts of the Columbia River Basalt Group and the John Day and Clarno Formations (Walker and others, 1967). In most parts of the province, however, the oldest rocks are aphyric and phyric basalt with plagioclase phenocrysts and minor andesite flows of middle(?) Miocene age. These flows, which have generally been referred to the Steens Basalt, are exposed principally along the southern and southeastern margin of the province; sections hundreds of meters thick are beautifully exposed in the glaciated canyons high on Steens Mountain. An average chemical composition of these

middle(?) Miocene flows (table l, column l) indicates a moderate to low silica content and a somewhat higher than normal alumina content; this average is not a fair representation, however, of the chemical diversity of these rocks, which vary considerably in their proportions of plagioclase, mostly labradorite, and olivine. Isotopic ages of the basalt flows indicate most were erupted about $15 \mathrm{~m} . \mathrm{y}$. ago (Baksi, and others, 1967; Laursen and Hammond, 1974; Walker, and others, 1974).

The basalts and andesites were overlapped by tuffaceous sedimentary rocks and subsequently by widespread sheets of ash-flow tuff. The ash-flow tuffs, which are of rhyolitic composition (table 1, columns 3, 4, and 5), spread laterally over tens of thousands of square kilometers of ancestral Harney Basin and form three principal units that are about 9,8 , and $6.5 \mathrm{~m} . y$. old. The total volume of erupted rhyplitic tephra is unknown but is in the range of $1,000-2,000$ $\mathrm{km}^{3}$. Eruption of this tephra was accompanied by collapse into evacuated magma chambers, which was partly responsible for the development of the large structural depression of Harney Basin. The depression was subsequently filled with younger ash-flow tuffs, tuffaceous sedimentary rocks, and basalt flows and palagonitic sediments--all of middle(?) and late Cenozoic age (Piper, and other, 1939; Baldwin, 1976; Greene and others, 1972). In places, the tuffaceous sedimentary rocks have been diagenetically altered to bentonitic clay minerals, zeolites, and potassium feldspar (Walker and Swanson, 1968), particularly where the sediments were deposited in ancient lakes that filled the lower parts of the structural depression. 


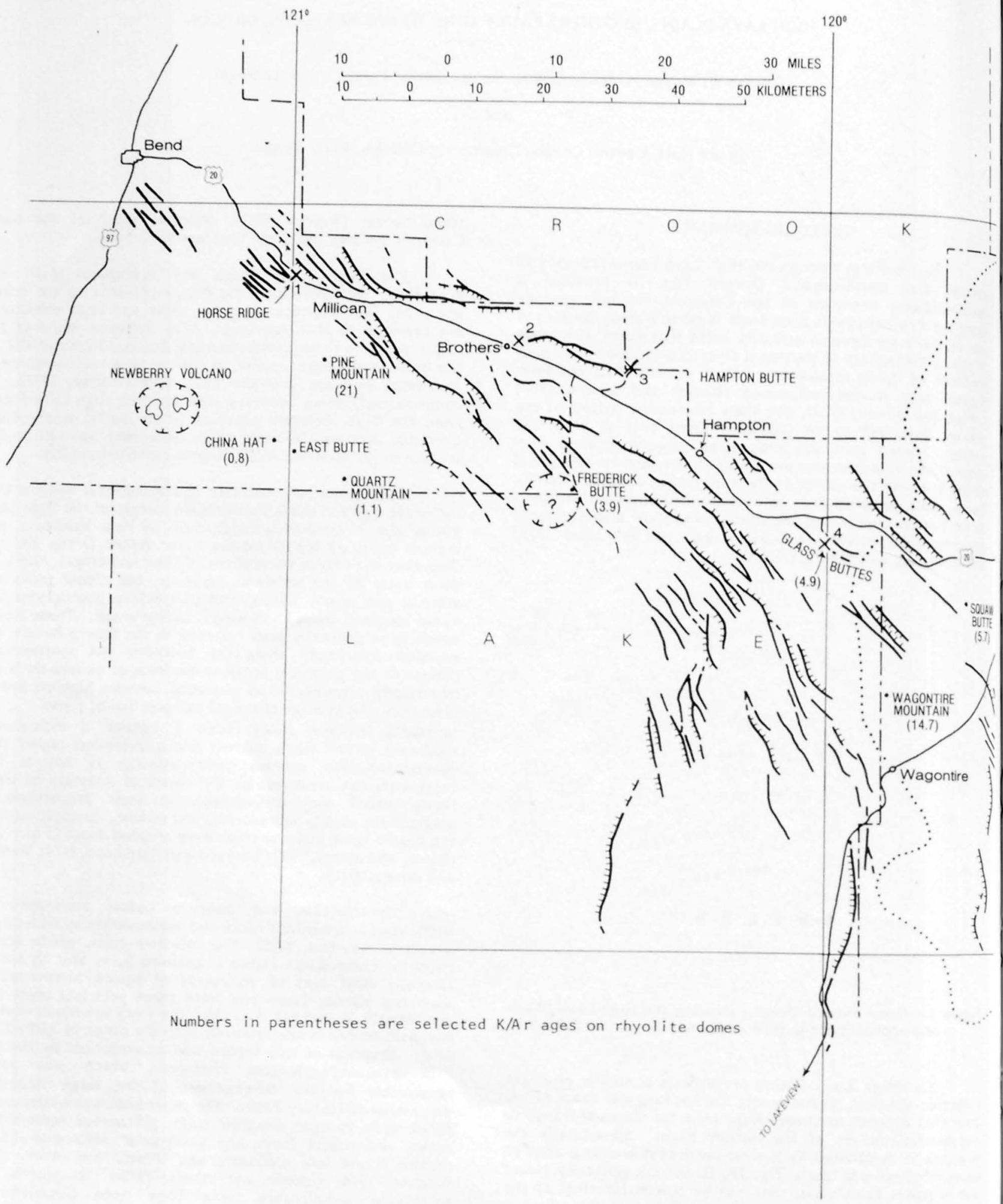

Figure 2A, B, and C.--Map showing route of field trip along U.S. Highway 20 from Bend to Harney Basin, major structural elements, and selected K/Ar ages on rhyolite 


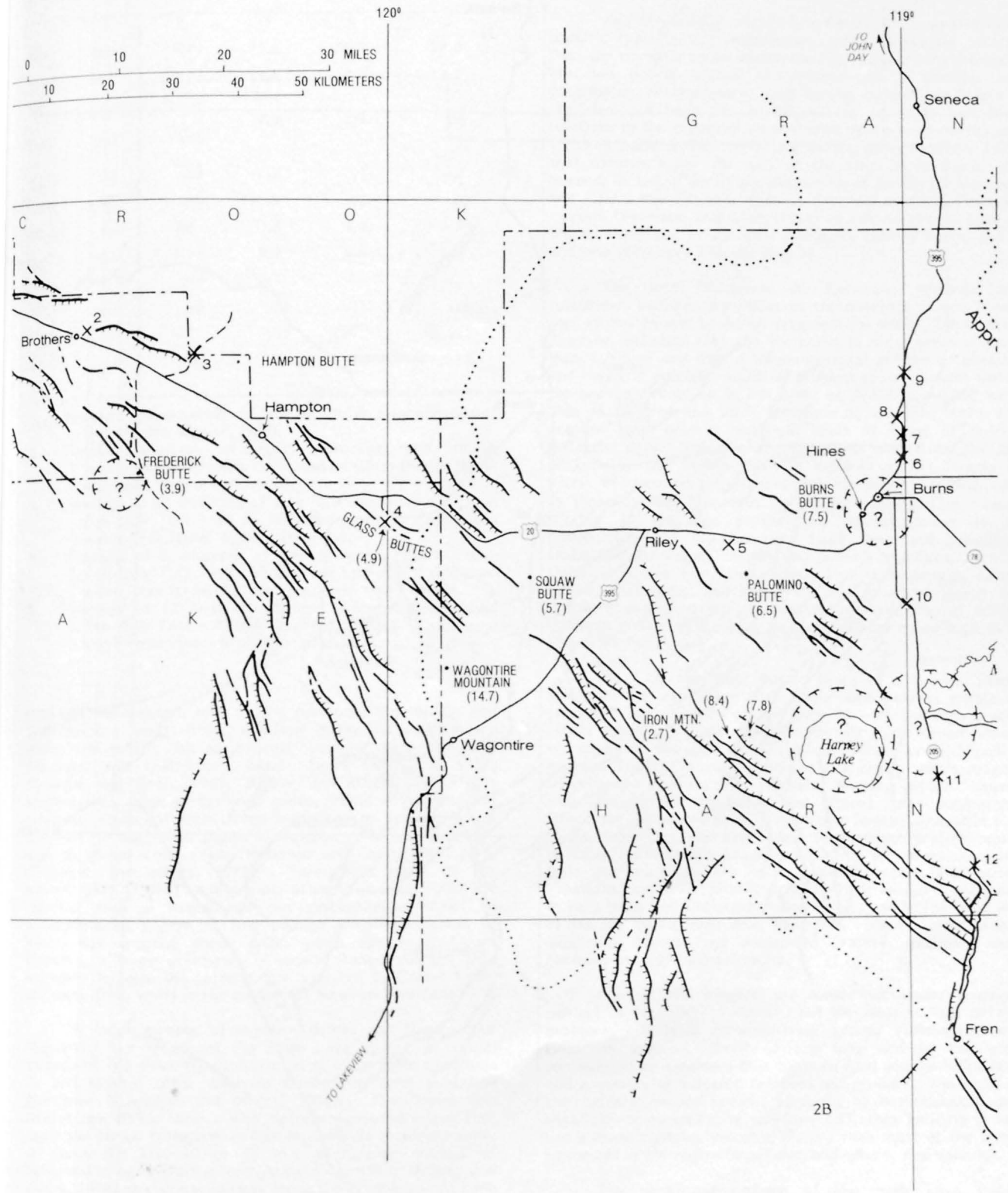


Table 1.--Average (or typical) chemical compositions of selected basaltic and rhyolitic rocks.

\begin{tabular}{lccccc}
\hline & 1 & 2 & 3 & 4 & 5 \\
$\mathrm{SiO}_{2}$ & 48.4 & 75.7 & 75.8 & 74.7 & 77.0 \\
$\mathrm{Al}_{2} \mathrm{O}_{3}$ & 16.7 & 13.4 & 11.6 & 12.3 & 12.1 \\
$\mathrm{Fe}_{2} \mathrm{O}_{3}$ & 4.3 & .26 & & & \\
$\mathrm{FeO}$ & 7.5 & .56 & 2.4 & 2.9 & .9 \\
$\mathrm{MgO}$ & 5.8 & .09 & .2 & .3 & .2 \\
$\mathrm{CaO}$ & 9.0 & .90 & .4 & .5 & .6 \\
$\mathrm{Na}_{2} \mathrm{O}$ & 3.0 & 3.8 & 3.8 & 4.4 & 3.5 \\
$\mathrm{~K}_{2} \mathrm{O}$ & 1.0 & 3.7 & 4.9 & 4.4 & 4.9 \\
$\mathrm{H}_{2} \mathrm{O}$ & 1.5 & .43 &.- & -- & -- \\
$\mathrm{TiO}_{2}$ & 2.2 & .10 & .21 & .15 & .16 \\
$\mathrm{P}_{2} \mathrm{O}_{5}$ & .4 &.- & .05 & -- & .15 \\
$\mathrm{MnO}^{-4}$ & .2 & .06 & .04 & -- & .17 \\
& & & & & \\
\hline
\end{tabular}

1. Average composition of 18 middle(?) Miocene basalt flows (from Walker, 1969).

2. Typical analysis of early Pliocene (4.9 m.y.), peraluminous rhyolite collected on Glass Buttes (from MacLeod, and others, 1976).

3. Average of 18 analyses of late Miocene Devine Lanyon Ash-flow Tuff. All Fe reported as FeO. Calculated water-free (from Walker, in press).

4. Average of 4 analyses of late Miocene Prater Creek Ash-flow Tuff. All Fe reported as Feu. Lalculated water-free (from Walker, in press).

5. Average of 12 analyses of late Miocene Rattlesnake Ash-flow Tuff. All Fe reported as Feo. Calculated water-free (from Walker, in press).

In the western part of the province, the middle and late Miocene basalt flows, ash-flow tuffs, and sedimentary rocks are mostly buried beneath younger late Miocene, Pliocene, and Quaternary basalt flows (Williams, 1957; Peterson and Groh, 1965; Walker and others, 1967) that erupted from widely scattered cones, shield volcanoes, and fissures. Charcoal from trees inundated by several young flows on the northwest flanks of Newberry Volcano have $\mathrm{C}^{14}$ ages of about 6,000 years (Peterson and Groh, 1965, p. 9; Chitwood, and others, 1977). Throughout much of the western part of the province most of these younger rocks are mantled with a widespread but discontinuous sheet of unconsolidated coarse to fine pumice fragments, some of which was erupted about 7,000 years ago from Mount Mazama, a large prehistoric Cascade Range volcano that collapsed to form the caldera now occupied by Crater Lake, and some from vents in the caldera of Newberry Volcano.

A large number of rhyolite domes and flows occur throughout the length of the High Lava Plains; a typical analysis of one dome (Glass Butte) is given in table 1 (column 2), and several other analyses have been been published elsewhere (MacLeod and others, 1976). The domes and related ash flows, show a well defined age progression that spans the period from late middle Miocene to Holocene time, or about the last 10 or 11 m.y. A large number of radiometric ages (Parker and Armstrong, 1972; McKee and others, 1976) of rhyolite masses along the Brothers fault zone and in areas to the south in the Basin and Range province demonstrate that the progression is not along a single linear belt of age-related domes and intrusive bodies, but rather along a broad front or possibly a series of parallel linear belts. The oldest dornes occur at the east and southeast edge of Harney Basin and the youngest at the west near Newberry Volcano.

Age of spatially related late Cenozoic basalt flows and basaltic (palagonitic) sedimentary rocks of greater volume than the rhyolitic rocks within the High Lava Plains province, are too poorly known to demonstrate a parallel age progression. Furthermore, most basalts comparable in age to the rhyolites have yet to be related to vents and their relations to the rhyolites are obscured by the west-northwesttrending band or belt of young basalt flows (Walker, 1977) that extends along the axis of the High Lava Plains and beyond, including basalt accumulations at Jordan (or Morcom) and Cow Lake Craters, east of Steens Mountain, Diamond Craters (Peterson and Groh, 1964) at the northwest base of Steens Mountain, at the west margin of Harney Basin, and in and near Newberry Volcano (fig. 3).

The total thickness of Cenozoic volcanic and tuffaceous sedimentary rocks in the province is not known and estimates are based on fragmentary data. These data, however, indicate that the thickness in most areas is more than $1,700 \mathrm{~m}$ and that a minimum total volume of basaltic and rhyolitic volcanic material erupted to the surface within the province must be on the order of 30,000 to $40,000 \mathrm{~km}^{3}$. This widespread and thick sequence of volcanic rocks was erupted from several different kinds of vents of several different ages. Volcanic accumulations older than the age progression and in the form of kipukas consist largely of silicic to intermediate eruptive and intrusive complexes, such as those at Pine Mountain and Wagontire Mountain. Vents related to the age progression, which appear to be concentrated in the Brothers fault zone and subsidiary fractures, consist of domes and dome complexes, such as those at China Hat, East Butte, Quartz Mountain, Glass, Squaw, Palomino, and Burns Buttes, some of which are probably resurgent domes related to very obscure buried calderas in Harney Basin or to ring-fracture zones such as at Frederick Butte.

Most of the older basalt flows in and near Steens Mountain are associated with major dike swarms visible on glaciated canyon walls on the east face of the high Steens block; younger flows are associated with broad shield volcanoes of low relief, with cinder zones, or with poorly exposed fissure zones. In places the rising basalt magma encountered ground or surface water, which caused fragmentation of the basalt and violent steam explosions. Where the explosions were of moderate intensity basaltic tuff cones, tuff rings, and tuff ridges formed; the best examples of these features are found about 40 to $60 \mathrm{~km}$ south of the field trip route at Fort Rock, Table Mountain, St. Patrick Mountain, and Seven Mile Ridge, all either within or marginal to Fort Rock and Christmas Lake Valley, and in the west end of Harney Basin, near Iron Mountain. More violent steam explosions blasted out prominent craters, including such features as Hole-in-the-Ground.

One of the largest and most spectacular eruptive centers is Newberry Volcano near the western end of the province. It is a comparatively young, Pleistocene and Holocene volcano, about $65 \mathrm{~km}$ long and $40 \mathrm{~km}$ wide surmounted by a caldera that contains East and Paulina Lakes and a variety of volcanic features and products; the walls of the caldera expose several varieties of both basaltic and rhyolitic rocks, including ash-flow tuff, that indicate it has had a more complex volcanic history than most of the other volcanoes in the region (MacLeod, and others, this volume).

The structural pattern of the High Lava Plains province is dominated by the northwest-trending Brothers fault zone which appears to be one of the fundamental structural elements of Oregon. The zone is continuously 


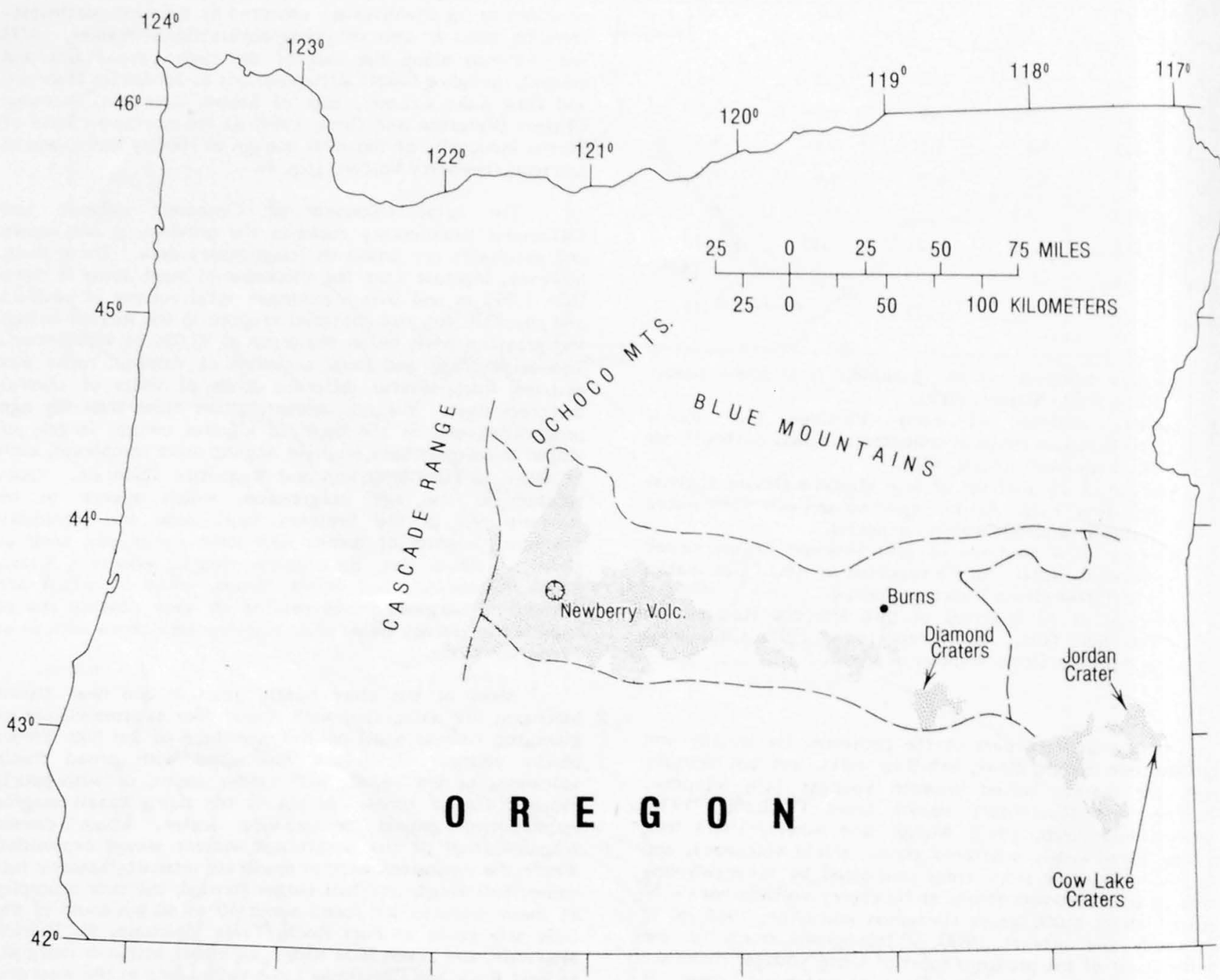

Figure 3.-- West-northwest-trending belt of Middle(?) and late Quaternary basalt fields. 
exposed for nearly $240 \mathrm{kin}$ through south-central Oregon. At ts west end it appears to swing northward into the Cascade Range at Green Ridge. Southeast of Harney Basin the faul zone may curve southward into Nevada (Stewart, and others, 975), or it may continue further east to and beyond Jordan Valley near the Idaho border. North of the fault zone, in the ochoco and Blue Mountains (fig. 1), older Cenozoic and preCenozoic rocks lie at the surface, whereas in and south of the zone a thick mantle of volcanic and volcaniclastic rocks buries the older rocks. Throughout the High Lava Plains, the zone is dominated at the surface by closely spaced (commonly $1 / 2-3 \mathrm{~km}$ apart) en echelon normal faults of moderate to small (mostly $10-100 \mathrm{~m}$ ) displacement that localized many sasaltic and rhyolitic vents of late Miocene through pleistocene age. The abundance and age distribution of vents indicate that recurrent crustal breaking has taken place along the zone for a considerable span of time. Also, many thertheast-trending structures in the southern part of the region, including several of the large normal faults that bound major graben, terminate at this discontinuity or, in places, change direction and seem to merge into it. Apparently both the normal faults of the zone and the many volcanic vents along the zone represent only the surface manifestations of deformation on a large deeply buried structure, the exact nature of which is not known. The pattern of normal faults within and near the Brothers fault zone and the relation of many small monoclinal folds to the faults suggests, however, that the zone overlies a deeply buried fault with some lateral displacement; the normal faults denote only adjustment of brittle surface and near surface volcanic and tuffaceous sedimentary rocks. Analysis of surface features permits either right- or left-lateral displacement on this buried structure, al though right-lateral movement seems inore likely (Walker, and others, 1967; Lawrence, 1976).

\section{REFERENCES CITED}

Baksi, A. K., York, C., and Watkins, N. D., 1967, Age of the Steens Mountain geomagnetic polarity transition: Journal of Geophysics Research, v. 72, no. 24, p. 6299-6308.

Baldwin, E. M., 1976, Geology of Oregon (Revised): Kendall/Hunt Publishing Company, Dubuque, Iowa, $147 \mathrm{p}$.

Chitwood, L. A., Jensen, R. A., and Groh, E. A., 1977, The age of Lava Butte: The Ore Bin, v. 39, no. 10, p. 157-164.

Friedman, Irving, and Peterson, Norman, 1971, Obsidian hydration dating applied to dating of basaltic volcanic activity: Science, vol. 172, p. 1028.

Greene, R. C., Walker, G. W., and Corcoran, R. E., 1972, Geologic map of the Burns quadrangle, Oregon: U.S. Geological Survey Miscellaneous Investigations I-680, scale $1: 250,000$.

Laursen, J. M., and Hammond, P. E., 1974, Summary of radiometric ages of Oregon and Washington rocks, through 1972: Isochron/West, no. 9, 32 p.

Lawrence, R. D., 1975, Strike-slip faulting terminates the Basin and Range province in Oregon: Geological Society of America Bulletin, v. 87, no. 6, p. 846-850.

MacLeod, N. S., Walker, G. W., and McKee, E. H., 1976 Geothermal significance of eastward increase in age of upper Cenozoic rhyolitic domes in southeast Oregon: Second United Nations Symposium on the development and use of geothermal resources, Proceedings, v. 1, p. $465-474$.

McKee, E. H., MacLeod, N. S., and Walker, G. W., 1976, Potassium-argon ages of Late Cenozoic silicic volcanic rocks, southeast Oregon: Isochron/West, no. 15, p. 37-41.

Parker, Donald, and Armstrong, R, L., 1972, K-Ar dates and $\mathrm{Sr}$ isotope ratios for volcanic rocks in the Harney Basin, Oregon: Isochron/West, no. 5, p. 7-12.

Peterson, N. V., 1978, Clastic dikes in southeastern Oregon: The Ore Bin, v. 40, no. 7 , p. 130-131.

Peterson, N. V., and Groh, E. A., 1964, Diamond Craters, Oregon: The Ore Bin, v. 16, no. 2, p. 17-34.
Peterson, N. V., and Groh, E. A., (eds.), 1965, Lunar geological field conference guide book: Oregon Department of Ceology and Mineral Industries, Bulletin $57,51 \mathrm{p}$.

Piper, A. M., Robinson, T. W., Jr., and Park, C F., Jr., 1939, Geology and ground-water resources of the Harney Basin, Oregon: U.S. Geological Survey Water-Supply Paper 841, $189 \mathrm{p}$.

Stewart, J. H., Walker, G. W., and Kleinhampl, F. J., 1975, Oregon-Nevada lineament: Geology, p. 265-268.

Walker, G. W., 1969, Some comparisons of basalts of southeast Oregon with those of the Columbia River Group: Proceedings Second Columbia River Basalt Symposium, p. 223-237.

1974, Some implications of Late Cenozoic volcanism to geothermal potential in the High Lava Plains of southcentral Oregon: The Ore Bin, v. 36, no. 7, p. 109-119

1977, Geologic map of Oregon east of the 121 meridian: U.S. Geological Survey Miscellaneous Investigations Map I-902, scale 1,500,000.

1979, Revisions to the Cenozoic stratigraphy of Harney Basin, Southeastern Oregon: U.S. Geological Survey Bulletin 1475, in press.

Walker, G. W., Dalrymple, G. B., Lanphere, M. A., 1974, Index to potassium-argon ages of Cenozoic volcanic rocks of Oregon: U.S. Geological Survey Miscellaneous Field Studies Map MF-569, scale 1:1,000,000, text, table, 2 sheets.

Walker, G W., Peterson, N. V., and Greene, R. C., 1967, Reconnaisance geologic map of the east half of the Crescent quadrangle, Lake Deschutes, and Crook Counties, Oregon: U.S. Geological Survey Miscellaneous Geologic Investigations Map 1-493, scale 1:250,000.

Walker, G. W., and Swanson, D. A., 1968, Summary report on the geology and mineral resources of the Harney Lake and Malheur Lake areas of the Malheur National Wildlife Refuge, north-central Harney County, Oregon: U.S. Geological Survey Bulletin 1260-L, p. L1-L17.

Williams, Howel, 1957, A geological map of the central portion of the High Cascade Mountains: Oregon Department of Geology and Mineral Industries, in cooperation with U.S. Geological Survey, scales 1:125,000 and $1: 250,000$. 
ROADLOG FOR HIGH LAVA PLAINS, BROTHERS FAULT ZONE TO HARNEY BASIN, OREGON

George W. Walker, U.S. Geological Survey, Menlo Park, California 94025

and

Bruce Nolf, Central Oregon Community College, Bend, Oregon

This road log gives point by point information on the geology from Bend to Harney Basin and into the Diamond Craters area at the southeast margin of Harney Basin. The route of the field trip and the locations of some important geographic landmarks are shown on figures $2 \mathrm{~A}, 2 \mathrm{~B}$, and $2 \mathrm{C}$; the road $\log$ is keyed to these figures by mileages between principal points of interest and by field trip stops.

MILES Junction U.S. Hwys. 97 and 20 in Bend, Oregon, heading east on U.S Hwy. 20.

0.8 Jct. with Pilot Butte Road. Pilot Butte, a late Pliocene or early Pleistocene cinder cone, is lapped by a pumiceous air-fall dated at between 1 and $2 \mathrm{~m} . \mathrm{y}$.

For next few miles we travel on Pleistocene basalt cut by northwest-trending faults with displacements of up to $40 \mathrm{~m}$; physiographic relief reduced or eliminated by sedimentation in downthrown blocks.

4.3 Jct. of road to Alfalfa. For several miles traverse young basalt partly covered by Mazama ash. Highway begins climb through older $(7 \mathrm{m.y.}$.) near vent basalt flows and flow breccias that characterize Horse Ridge. Northwest-trending faults, with up to 150 $m$ vertical offset, cut these basalts.

STOP NO. 1. At road jct. Geologic features that can be seen from this point include (from oldest to youngest):

a. Pine Mountain to southeast, a kipuka of silicic to intermediate volcanic rocks dated at about $21 \mathrm{~m} \cdot \mathrm{y}$.

b. To west and north, faulted late Miocene ( $\approx 7$ m.y.) basalt of Horse Ridge. Note fault scarp north of and parallel to the highway. North of this fault are several additional and parallel normal faults which have localized basaltic vents in the form of small lava cones and cinder cones.

c. To southwest the large volcanic edifice is Newberry Volcano. (Refer to MacLeod and others, this volume.)

d. To south, China Hat and East Butte represent silicic domes near west end of the age progression of silicic domal rocks along the Brothers fault zone (MacLeod and others, 1976). Age of China Hat is $0.78 \pm 0.20 \mathrm{~m} . \mathrm{y}$. and East Butte is $0.85 \pm 0.05 \mathrm{~m} . \mathrm{y}$.

e. Low terrain to south and southeast is underlain by young basalt flows and lacustrine and fluviatile sediments of probable Pleistocene age.

Note that normal faulting along this part of the Brothers fault zone is bracketed by the 7 m.y. basalt of Horse Ridge and the basin fill. Faulting of Newberry Volcano and of flows in Bend basin indicate some displacements in middle Pleistocene to Holocene time. 
As we leave this stop, note thin-bedded lacustrine sediments in roadcut on nor th side of highway and a mile or so further on, and also on north side of highway, echelon normal faults that cut basalt of Horse Ridge.

Millican. Note scarp of another echelon fault north of highway.

Second flow from top of basalt sequence exposed on scarp north of highway has been dated at 6.5 m.y.

Younger, much less faulted flows interbedded with gravelly sediments adjacent to highway.

Jct. with State Hwy. 27.

STOP NO. 2. at Brothers rest area. Flat topped ridge to northwest is capped by basalt of late Miocene age, probably comparable in age to basalt of Horse Ridge. Irregular treecovered hills to the north and ridges forming northern skyline are composed of Eocene to middle Miocene volcanic and volcaniclastic rocks, including the Picture Gorge Basalt and the John Day and Clarno Formations. Foreground is underlain by Quaternary basalt and sediments. Source for some younger flows is low conical hill to the east-northeast with a tank on top. Rounded hill to south of highway is rhyolite of unknown age, probably older than the age progression.

Jct. with road south to Frederick (Fredrick) Butte. Fault scarp north of highway is in late Pliocene or Pleistocene basalt.

Jct. Camp Creek road. Turn northeast off highway on side trip. Go 3.6 miles to cattle guard. STOP NO. 3. Rim to the northeast of cattle guard is $3.9 \mathrm{~m} . y$. old ash-flow tuff which apparently came from vent area south of highway. Frederick Butte, to southsouthwest, is $3.9 \mathrm{~m} . \mathrm{y}$. old and composes one of several rhyolite domes on the east margin of a circular collapse area, probably the source of this ash-flow tuff.

Note that the ash-flow tuff and overlying basalt are cut by faults and here are downdropped south of the fault. South of highway both basaltic and rhyolite vents can be seen as low hills. Hampton Butte, to east, is a volcanic pile that includes older rocks and intrusive rhyolite. The Clarno Formation crops out on west side and intrusive rhyolite forms conspicuous hill on south side of Hampton Butte. Return to U.S. Hwy 20 and continue east.

South of highway both north and south facing fault scarps are visible that cut Pliocene and Pleistocene basalts (younger than ash-flow tuff from Frederick Butte vent complex).

Note ash-flow tuff rims north of highway.

Hampton Station. As we approach Glass Buttes, the faulted basalts on both sides of highway are probably Pliocene in age. Some of these basalts appear to lap against the rhyolite domes of Glass Buttes.

Jct. Buck Creek Road, to G. I. Ranch.

Jct. with BLM road to south. Side trip to outcrops of dated obsidian associated with Glass Buttes volcanic complex. Drive 2.7 miles to small reservoir.

STOP NO. 4. Outcrops of obsidian, dated at 4.9 m.y., on both sides of wash. Glass Buttes complex is elongate in northwest-southeast direction, approximately parallel to the Brothers fault zone. At the east end of this group of rhyolite domes are opalite-type mercury deposits and a thermal well. Return to highway.

Note large mafic vent north of highway that fed Plio-Pleistocene basalt flows. Proceed east on U.S. Hwy. 20. 
Juniper-covered hills north of highway are another rhyolitic complex elongate nor thwestsoutheast parallel to the fault zone.

(3.4)

84.8

(11.4)

96.2

102.4

103.7

111.6

(0.5)

112.1

(4.0)

116.1

(2.7)

131.6

135.1

Squaw Butte visible ahead. Squaw Butte sits in the middle of another rhyolitic complex, dated at 5.1 m.y., surrounded by basalt which in places laps onto the rhyolite.

Dry Mountain north of the highway is a large rounded volcanic pile of faulted middle Miocene hypersthene andesite lapped by 6-m.y.-old ash-flow tuffs. A few miles north of Dry Mountain, pre-Cenozoic rocks are exposed, some as old as Devonian. Valley north of highway and south of Dry Mountain is filled with Pleistocene gravel and a few thin Pliocene and Pleistocene basalt flows.

Jct. U.S. Hwy 395 (Riley). Fault scarps cutting Pliocene or possibly late Miocene basalt flows to the north and northeast of highway.

Sharp peak on southern skyline is Iron Mountain, a rhyolite dome dated at 2-3 m.y. This appears to be the only exception in the well-defined age progression in silicic volcanism.

Enter area underlain by palagonitic (basaltic) bedded tuffs of Pliocene and Pleistocene age.

Ditch on north side of highway provides best exposures of these tuffs.

STOP NO. 5: Highway rest area.

Palamino Buttes, south of highway, consists of 6.5-m.y.-old rhyolite; adjacent to Buttes on east is eroded basaltic cinder cone. Buttes lapped by basalt flows dated elsewhere at $2-3-m . y$. Both the basalt and underlying rhyolite are cut by northwest-trending normal faults with decreased offset of the basalt.

South of highway for next several miles, rim of 2-3-m.y. basalt underlain by tuffaceous sedimentary rocks generally referred to as part of the Harney Formation. These sedimentary rocks rest on the Rattlesnake Ash-flow Tuff.

Exposure of Rattlesnake Ash-flow Tuff in roadcut.

Outcrop of rhyolite south of highway and additional outcrops to northeast and north of highway. These rhyolites are part of the Burns Butte volcanic complex which has been dated at $7.8 \mathrm{~m} . y$. Within the complex are some mafic cinder cones.

Borrow pit on south side of highway exposes one of these mafic cinder cones. Clastic dikes cutting these cinder cones have recently been described by Peterson (1978).

City limits of Hines, Oregon.

Jct. of U.S. Hwy 20 (also U.S. Hwy 395) and State Hwy. 78 in the center of Burns, Oregon. Burns lies at the northwest margin of a nearly circular area that represents central Harney Basin, an area characterized mostly by flat-lying younger fill and some dune deposits. Central Harney Basin lies within a much larger structurally depressed area that coincides approximately with the physiographic basin outlined on fig. 2 . The structural basin evolved in part concurrently with the eruption of late Miocene ash-flow tuffs, which are traversed by the next stage of the field trip.

Turn north on U.S. Hwys. 20 and 395.

Jct. U.S. Hwy. 20 and 395, turn north on 395.

STOP NO. 6: Exposures, about $20 \mathrm{~m}$ thick, of Rattlesnake Ash-flow Tuff, which has been dated at about $6.4 \mathrm{~m} . \mathrm{y}$. on the basis of numerous analyses. A single flow and cooling unit of rhyolitic ash-flow tuff that rests on bedded sedimentary rocks. Consists of a well 
developed basal vitrophyre, an overlying glassy zone containing abundant spherulites, and a thick vapor-phase zone characterized by abundant lithophysae above that. The unit dips gently southward into Harney Basin. This ash-flow tuff originally covered nearly $50,000 \mathrm{~km}^{2}$ of east-central and southeast Oregon, reaching a maximum thickness near Iron Mountain (southwest part of Harney Basin) of more than $60 \mathrm{~m}$.

Vents for this and underlying late Miocene ash-flow tuffs are buried beneath younger fill in the lower central part of Harney Basin. Only indirect and meager evidence is available as to their location and character.

(1.0)

136.1

(0.7)

136.8

(1.3)

138.1

142.2

$(0.0)$

(1.7)

STOP NO. 7: Prater Creek Ash-flow Tuff exposed in road cut. Single flow and cooling unit that is $8.4 \mathrm{~m} . y$. old, and is slightly more mafic than the Rattlesnake and Devine Canyon Ash-flow Tuffs. This unit is characterized by low crystal content and abundant lithophysae. Maximum thickness is about $30 \mathrm{~m}$; its extent is poorly known because it is largely buried by younger materials including the Rattlesnake Ash-flow Tuff. Unit is underlain by bedded tuffaceous sedimentary rocks; inter-ash-flow tuff units thin away from central Harney Basin.

Cross railroad tracks.

STOP NO. 8: Upper non-welded part of Devine Canyon Ash-Flow Tuff. Columned ashflow tuff across creek to the north-northwest is welded and compacted lower part of the same unit, samples of which have been dated from a number of widely separated localities at about 9.2 m.y.

STOP NO. 9: Outcrops on both sides of road of Devine Canyon Ash-flew Tuff. A single cooling, probably multiple-flow unit that covers more than $18,000 \mathrm{~km}^{2}$ centered on the east half of Harney Basin and extending north, south, and east of the basin. Maximum thickness is about 35 to $40 \mathrm{~m}$, although most of the unit is less than $10 \mathrm{~m}$ thick. Isopaching suggests a source caldera in the vicinity of Burns, perhaps with its west margin in the vicinity of Burns Butte. Contains as much as 30 percent crystals and crystal fragments, mostly sodic sanidine, some quartz, and minor, ubiquitous green ironrich clinopyroxene. Thinner distal ends tend to be glassy, whereas thicker sections exhibit more devitrification and locally extensive vapor-phase alteration.

At this point turn around and return to Burns.

\section{LOG FROM BURNS TO DIAMOND CRATERS}

Jct. of U.S. Hwys. 20 and 395 with State Hwy. 78. Head east on 78.

Jct. State Hwys. 78 and 205. Turn south on 205.

STOP NO. 10: Viewpoint on spur gravel road, south rim of Wrights Point. Wrights Point consists of a $2.4-\mathrm{m} . \mathrm{y}$. valley-fill basalt flow which has been eroded into positive relief. The point extends $6.5 \mathrm{~km}$ from here eastward; the vent is several kilometers to the west. Visible beneath the basalt flow are some of the best exposures of bedded tuffaceous sedimentary rocks of the Pliocene Harney Formation.

From this point looking to the south-southwest, the juniper-covered hill is Dog Mountain, original site of the type section of the Harney Formation. Inasmuch as Dog Mountain is a palagonite tuff ring, atypical of the formation, road cuts on Wrights Point have been recently designated a reference section (Walker, in press). The tuff ring is late Pliocene. West of Dog Mountain are a number of additional young basaltic vents (tuff rings, cinder cones, lava cones, and dikes). East and southeast of Dog Mountain are many more young basaltic vents, including those at Malheur National Wildlife Refuge Headquarters, at Coyote Buttes, and Diamond Craters.

Steens Mountain (elev. 9,733 feet; 2,967 m), a west-tilted fault block capped by the middle Miocene Steens Basalt dominates the southeast skyline. On the east-southeast skyline is Duck Butte, a large rhyolitic dome complex about $10 \mathrm{~m} . \mathrm{y}$. old, considered by 
(10.7)

(1.5)

43.6

MacLeod and others (1976) as probably the oldest rhyolitic unit within the age progression.

Excellent view to the west of the rhyolitic dome at Iron Mountain.

Bridge at Narrows. Some geophysical data suggest that one or more source calderas for the late Miocene ash-flow tuffs are centered about here ( $\mathrm{H}$. R. Blank, oral communication, 1974). Harney Lake, to west, is the current sump of the Harney Basin drainage system. Low hills to the east are young basaltic cinders, palagonite tuffs, and related flows.

Jct. with road to Malheur National Wildlife Refuge Headquarters and to Princeton, Oregon. Along this road are numerous young basaltic vents, mostly characterized by low rounded hills consisting of red cinders, common cored bombs, and agglutinated basalt.

STOP NO. 11: Roadcut in a crystal-poor pumicite that is thoroughly altered by zeolitization (erionite, clinoptilolite, etc) and may represent either an ash-flow tuff or a pumice slurry deposit that flowed into shallow water. Pumice fragments are neither collapsed nor welded.

Excavated basaltic cinder cone to east of highway. Rim on west side of road is welded pumiceous ash-flow tuff, probably Rattlesnake Ash-flow Tuff. Cap on Saddle Butte is a basalt flow interstratified with the Harney Basin depositional sequence.

Exposures in low roadcut of non-compacted, non-welded, partly altered crystal-rich Devine Canyon Ash-flow Tuff. Alteration suggests that this also may represent deposition of ash-flow in wet environment.

STOP NO. 12: On moderately well welded crystal-rich Devine Canyon Ash-flow Tuff (9.2 m.y.). This is overlain by pumiceous ash-flow tuff to the west and is underlain locally by as much as $150 \mathrm{~m}$ of bedded tuffaceous sediments which lap south and southeastward on to middle Miocene ( $\approx 15 \mathrm{~m} . y$.) Steens Basalt. The overlying pumiceous tuff also thins to the south.

Note the several northwest-trending fault scarps in which units are stepped up to the south. This is a prominent northwest-trending zone which can be traced almost $100 \mathrm{~km}$.

Exposures of densely welded Devine Canyon Ash-flow Tuff.

Turn left on paved road to Diamond, Oregon.

Rimrock on both sides of road is Devine Canyon Ash-flow Tuff. View to south-southwest of large northeast-trending, east-facing scarp along the fault zone that separates the west-tilted High Steens block from the Jackass Mountain block. This is one locality near the southern margin of the Brothers fault zone where a northeast-trending fault system curves into a northwest-trending system.

Excellent profile to the north of the Diamond Craters volcanic complex. This complex has been studied by Peterson and Groh (1964). From here can be seen a few vents and local gentle doming of basalt flows within the complex. The valley to the north and east is underlain by surficial deposits resting on Devine Canyon Ash-flow Tuff which is faulted and underlies the Diamond Craters complex.

Turn north on gravel road to Diamond Craters.

Left at "Y" on road to Diamond Craters. Shortly beyond this point we see basalt flows of the Diamond Craters complex that lap onto Devine Canyon Ash-flow Tuff.

Road jct. at borrow pit in cinder cone. The principal part of the complex is west and north of this point. 
STOP NO. 13; END MILEAGE LOG. Travel from here is dependant on time available and interest of participants. Following are notes from selected viewpoints.

a. On hill top, approximately $1 \mathrm{~km}$ north of borrow pit jct., we are on the south margin of a 2.3-km-long northwest-trending graben along the crest of an elongate domal structure in the basalt. This graben was apparently the site of little or no eruptive activity. Summit collapse probably resulted from withdrawal of lava from a highstanding magma body beneath this up-arched structure. The complex includes five of these elongate domal structures all of which are oriented in a northwest-southeast direction.

Four of the five are characterized by various degrees of summit fracture and collapse.

In the near foreground to the south is a prominent pit crater and related basalt flows. Many of these youngest vents are localized at the margin of domal structures (at point of maximum flexure) and represent points of lava egress at times of summit collapse.

The tendency to use degree of vegetative cover to determine relative ages of flows can be misleading. For example, in the foreground to the south, the flow with more sagebrush cover laps onto the less vegetated flow.

Based on evaluation of weathering features in this dry environment, we believe that this basaltic complex is late Pleistocene in age, rather than Holocene. Thus far no materials suitable for isotopic dating have been found, but an age of $17,000+2,000$ years was obtained by Friedman and Peterson (1971) on hydration rinds of rhyolitic material enclosed in basalt bombs.

Jackass Mountain, to the west-southwest, is the high point on the Jackass Mountain fault block which is bounded by prominent scarps. Most of the rims to the south are faulted and eroded Devine Canyon Ash-flow Tuff. Some patches of Rattlesnake Ash-flow Tuff are present on the back (west) slope of Steens Mountain. The giant west-dipping Steen Mountain block is bounded on the east by a precipitous northeast-trending, 1,800-m-high fault scarp, and is lapped on the west by sedimentary rocks containing a Barstovian vertebrate fauna and by late Miocene ash-flow tuffs and interbedded sedimentary rocks.

NOTE: For those interested, a loop road between Frenchglen and northern Catlow Valley traverses the dip slope and crest of the High Steens.

The lower country to the north of the Diamond Craters complex is locally underlain by accumulations of young basalt, mostly valley-filling flows. Some of these flows effectively closed off the pluvial drainage from Harney Basin.

On the skyline to the north, older rocks crop out north of the Brothers fault zone.

b. Approximately $2 \mathrm{~km}$ west of the graben is a large vent area referred to by Peterson and Groh (1964) as the central crater complex. This complex is localized by a partly filled northwest-trending graben at the crest of another elongate domal structure. Probably graben development and eruptive activity were at least in part contemporaneous. More than 30 separate vents have been identified within this depression. Vent activity ranged from quiet emission of lava to highly explosive volcanophreatic events. Blocks of Devine Canyon Ash-flow Tuff and associated units are found in the tephra; exotic blocks up to $50 \mathrm{~m}$ in maximum dimension are present. Other features within this central crater complex include exhumed conduits, driblet spires and spatter cones, and small-scale collapse structures. 
A FIELD TRIP TO THE MAAR VOLCANOES OF THE FORT ROCK - CHRISTMAS LAKE VALLEY BASIN, OREGON G. H. Heiken, Geosciences Division, Los Alamos Scientific Laboratory, Los Alamos, NM 87545

R. V. Fisher, Dept. of Geology, University of California, Santa Barbara, CA 93106

N. V. Peterson, State of Oregon, Dept. of Geology and Mineral Industries, Grants Pass, OR 97526

The Fort Rock - Christmas Lake Valley basin is a former lake basin that existed from late Pliocene through late Pleistocene time. The basin is about $64 \mathrm{~km} 10 \mathrm{ng}$ and $40 \mathrm{~km}$ wide (Fig. 1). Eruptions of basaltic magma occurred along faults that trend diagonally across the basin and adjacent highland, forming maar volcanoes within and on lake margins and forming cinder cones with flows beyond the lake margins (Peterson and Groh, 1963; Heiken, 1971).

The purpose of this field trip is to visit several of the maars and a maar complex in and near the basin.

Road Log: (cumulative distance, in miles; stop-to-stop mileages are in parentheses) (Fig. 2).

0.0 La Pine Junction; intersection of Oregon State Highways 97 and $31 . \quad$ Proceed down Highway 31 , to the southeast.

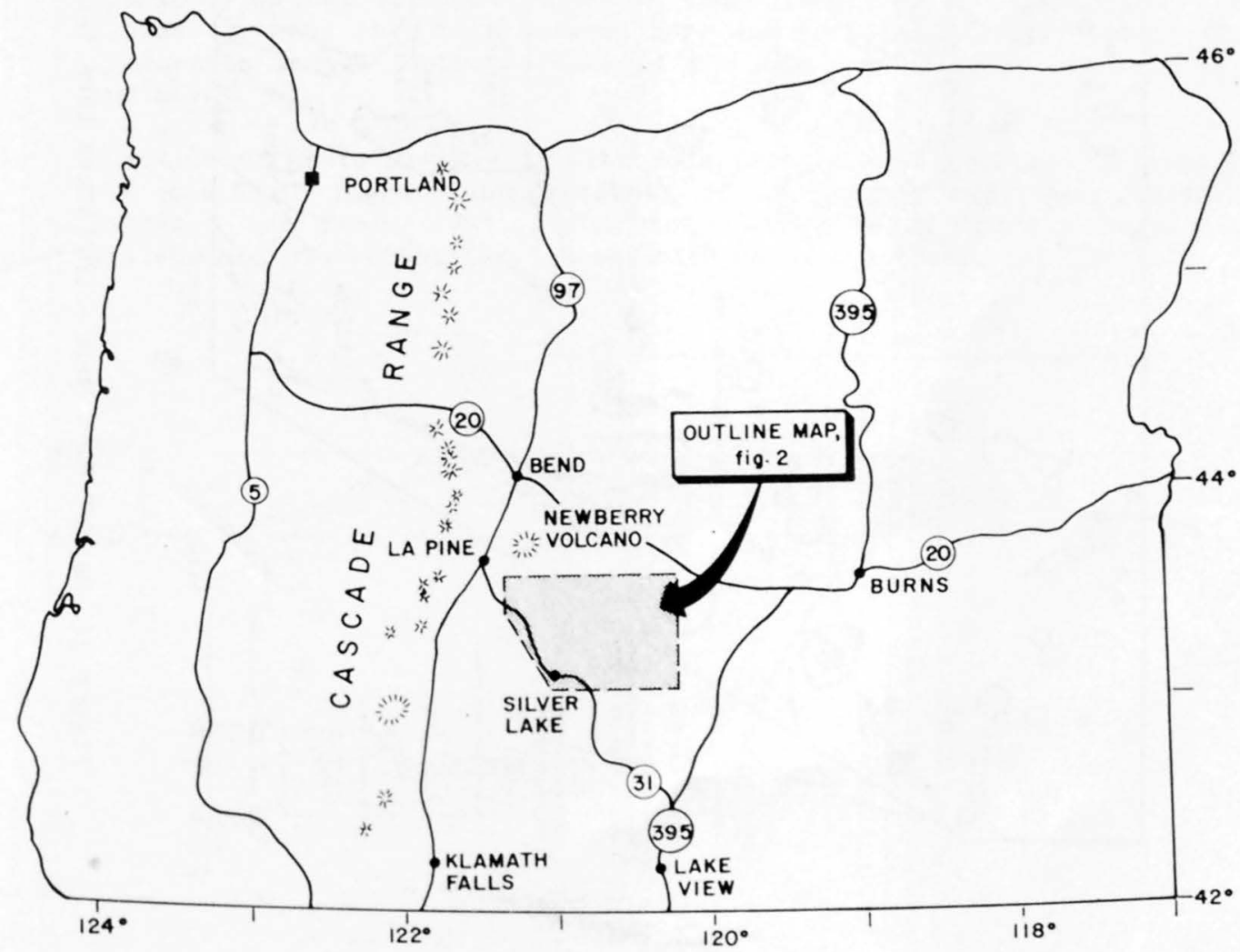

Figurs 1: Location map. 


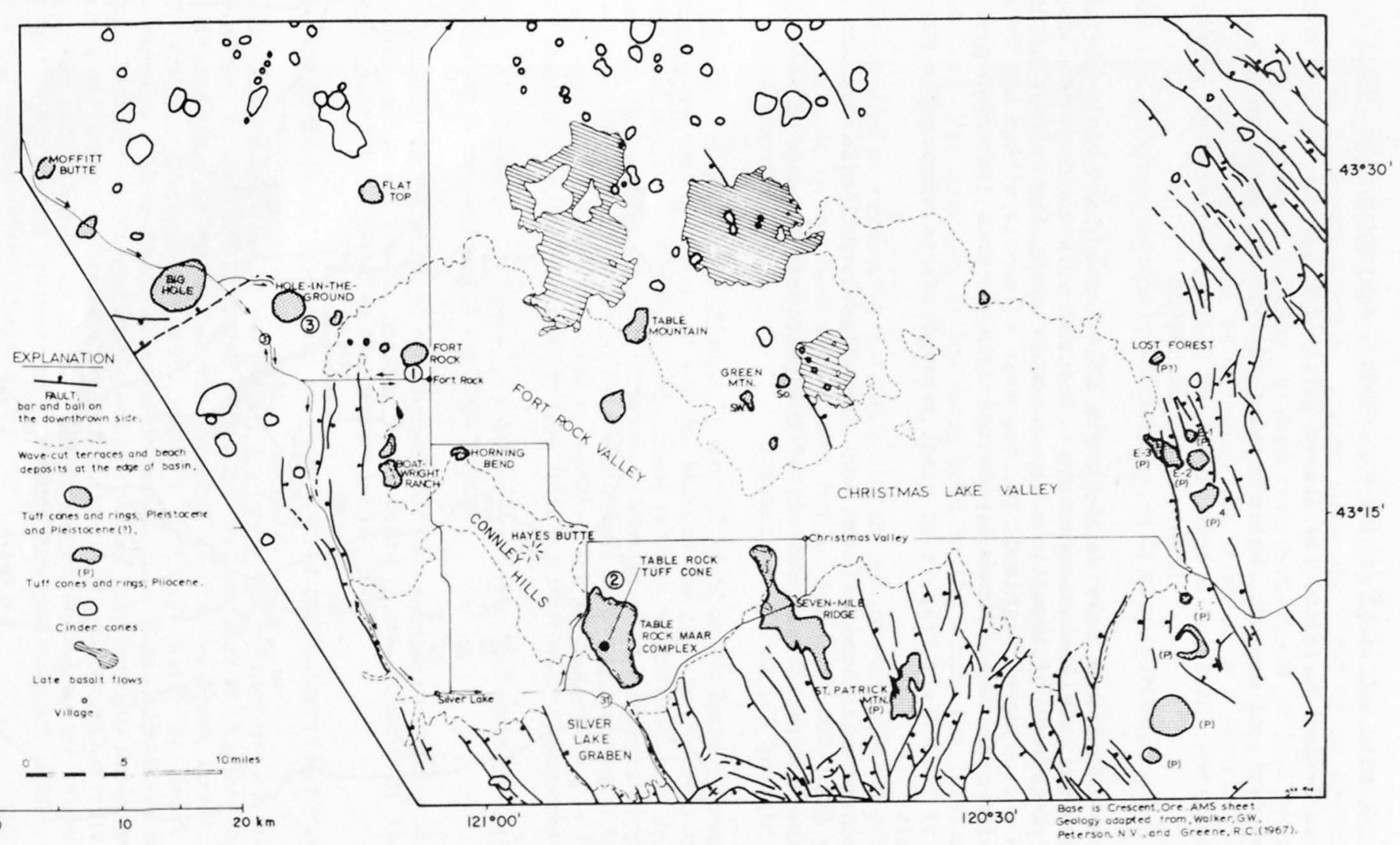

Figure 2: Map of Fort Rock - Christmas Lake Valley Basin, showing route of field irip. 
Railroad crossing; as is typical of the area between La Pine Junction and Fort Rock Valley, the surface (except for steepest slopes) is mantled with Mazama

(7.1)

10.0 pumice from crater Lake.

$(0.3)$

10.3

Bend in road; Moffitt Butte tuff ring is straight ahead.

Moffitt Butte is on left; its base is about $50 \mathrm{~m}$ east of road in the woods.

\section{Moffitt Butte}

Moffitt Butte is a dissected tuff ring, $1400 \mathrm{~m}$ in diameter and $120 \mathrm{~m}$ high. It is a prominent topographic feature, but is obscured by the forest from the road. Although not associated with a lake basin, as is the case for Big Hole and Hole-in-the-ground, Moffitt Butte is a tuff ring composed of hyaloclastic tuffs. Rising magma may have encountered permeable aquifers beneath the cone. A line of tuff rings between here and the Fort Rock Basin are along a topographic low between Fort Rock and the La Pine basins.

The crater floor of Moffitt Butte is about $80 \mathrm{~m}$ above the surrounding plain. A parasitic vent, and small tuff ring, $510 \mathrm{~m}$ in diameter, is located on its southwestern flank. The deposits consist of sideromelane lapilli-tuff in graded and ungraded beds, 3 to $30 \mathrm{~cm}$ thick. Near the main ring crest is an unconformity dipping $20^{\circ}$ into the crater that truncates beds dipping outward at $35^{\circ}$ (Fig. 3). Rocks above the unconformity consist of a $1 \mathrm{~m}$ thick bed of angular basalt blocks and $18 \mathrm{~m}$ of very well-bedded lapilli-tuff.

The crater of the parasite vent is filled with lava that issued from a dike on its northwest edge.

13.1 Road cut through pressure ridge or large tumuli in a basalt flow. This is typical of many road cuts between here and Fort Rock Valley; basalt flows are from vents on the southern flank of the Newberry Volcano; overlain by Mazama pumice.

(1.5)

14.6

Junction of State Highway 31 with Rock Creek Road (gravel). Exposed in road cut south of highway are remnants of an unnamed tuff ring (Ridge 28 of Peterson and Groh, 1963); gray to orangish-brown (partly palagonitized), well-bedded hyaloclastites. Most units contain accretionary lapilli.

NW

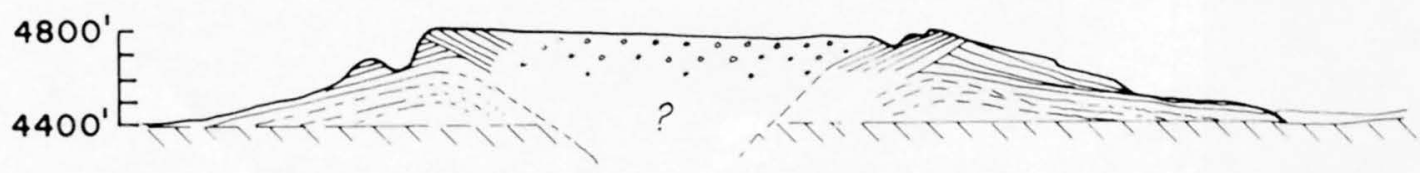

NE SW

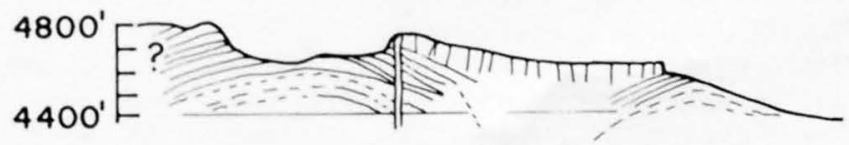

Figure 3: Cross-sections through Moffitt Butte, Klamath County Oregon. The upper cross section is through the main body of the tuff ring. The lower cross-section is through a parasitic vent on the southwest flank of the ring; the lava-filled crater is close to the highway. 
Big Hole

A gravel road from this junction goes into the crater of Big Hole, a circular, 1820 m diameter maar crater. Deposits of the tuff ring are 24 to $30 \mathrm{~m}$ thick at the crest and extend 1800 to $2500 \mathrm{~m}$ beyond the crater rim. The deposits are thickest on the northeast side, along Highway 31 (Big Hole Butte).

The tuff ring is composed of moderate- to well-bedded sideromelane lapilli-tuff and tuff breccia, in beds $5 \mathrm{~cm}$ to a meter thick. The tuff-breccia beds include porphyritic basalt blocks up to $2.5 \mathrm{~m}$ in diameter; there are abundant bedding plane sags caused by impact of these blocks into once water-saturated ash beds during the eruption. Best exposures of these deposits are along gullies on the eastern rim of the maar. Convolute bedding within the rim deposits is well exposed along the east rim (Fig. 4).

Within the crater is a 152 m-wide ledge that appears to be the top of a large block that slumped into the crater, possibly during the eruption. Collapse into the crater of such large blocks would explain the large volume of the crater and small percentage of xenoliths within the ejecta.

$(0.6)$

20.2 On the right are well-bedded hyaloclastic tuff deposits of Big Hole tuff ring. Deposits are thicker on the northeast rim, probably caused by prevailing winds from the southwest during the eruption. The thicker deposit is called Big Hole Butte, although it is not a separate structure or vent.

$(0.4)$

20.6

(4.5)

25.1

Good exposure of Big Hole tuffs on right side of Highway 31.

Junction of State Highway 31 with the road to Hole-in-the-ground (HIG) (Proceed along Boundary Road, \#245). The side trip to HIG will not be included in the overall mileage. Forest Road 245 is gravel; follow signs for 2.8 miles (one left turn and one right turn to the west rim and to HIG overlook).

\section{Hole-in-the-ground}

Hole-in-the-ground is described by Peterson and Groh (1961, 1963) and by Lorenz (1971). Lorenz's (1971) abstract is as follows:

"Hole-in-the-Ground is a volcanic explosion crater or maar located in Central Oregon on the edge of Fort Rock basin. At the time the crater was formed between 13,500 and 18,000 years ago a lake occupied most of the basin and the site of the eruption was close to the water level near the shore. The crater is now 112 to $156 \mathrm{~m}$ below the original ground level and is surrounded by a rim that rises another 35 to $65 \mathrm{~m}$ higher.

The volume of the crater below the original surface is only 60 percent of the volume of the ejecta. The latter contains only 10 percent juvenile basaltic material, mainly sideromelane produced by rapid quenching of the lava. Most of the ejected material is fine grained, but some of the blocks of older rocks reach dimensions of 8 $\mathrm{m}$. The largest blocks are concentrated in four horizons and reached distances of $3.7 \mathrm{~km}$ from the center of the crater. Accretionary lapilli, impact sags, and vesiculated tuffs are well developed.

The crater was formed in a few days or weeks by a series of explosions that were triggered when basaltic magma rose along a northwest-trending fissure and came into contact with abundant ground water at a depth of 300 to $500 \mathrm{~m}$ below the surface. After the initial explosion, repeated slumping and subsidence along a ring-fault led to intermittent closures of the vent, changes in the supply of ground water, and repeated accumulations of pressure in the pipe. Four major explosive events resulted from pressures of over 500 bars in the orifice of the vent. Ejection velocities during these periods reached 200 meters per second. The corresponding pressures 


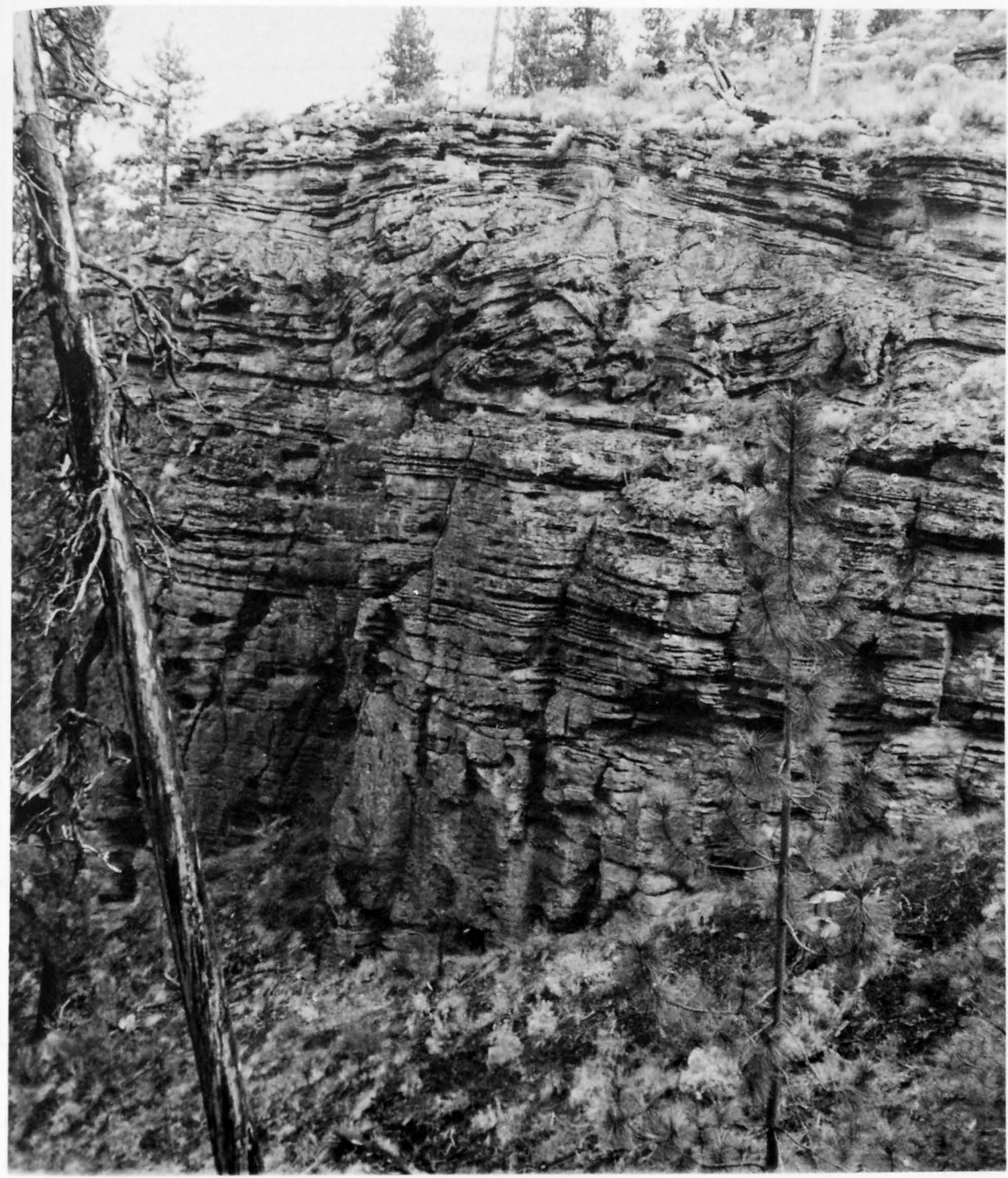

Figure 4: Maar deposits, east rim of Big Hole. We11-bedded tuffs and 1apil1ituffs are characteristic of the maar volcanoes of this region. Convolute bedding is well displayed in places; it is caused by decollement-like movement of cohesive tuff down the flank of the tuff ring. 
CENTER FOR VOLCANOLOGY

UNMERSITY OF OAEGON

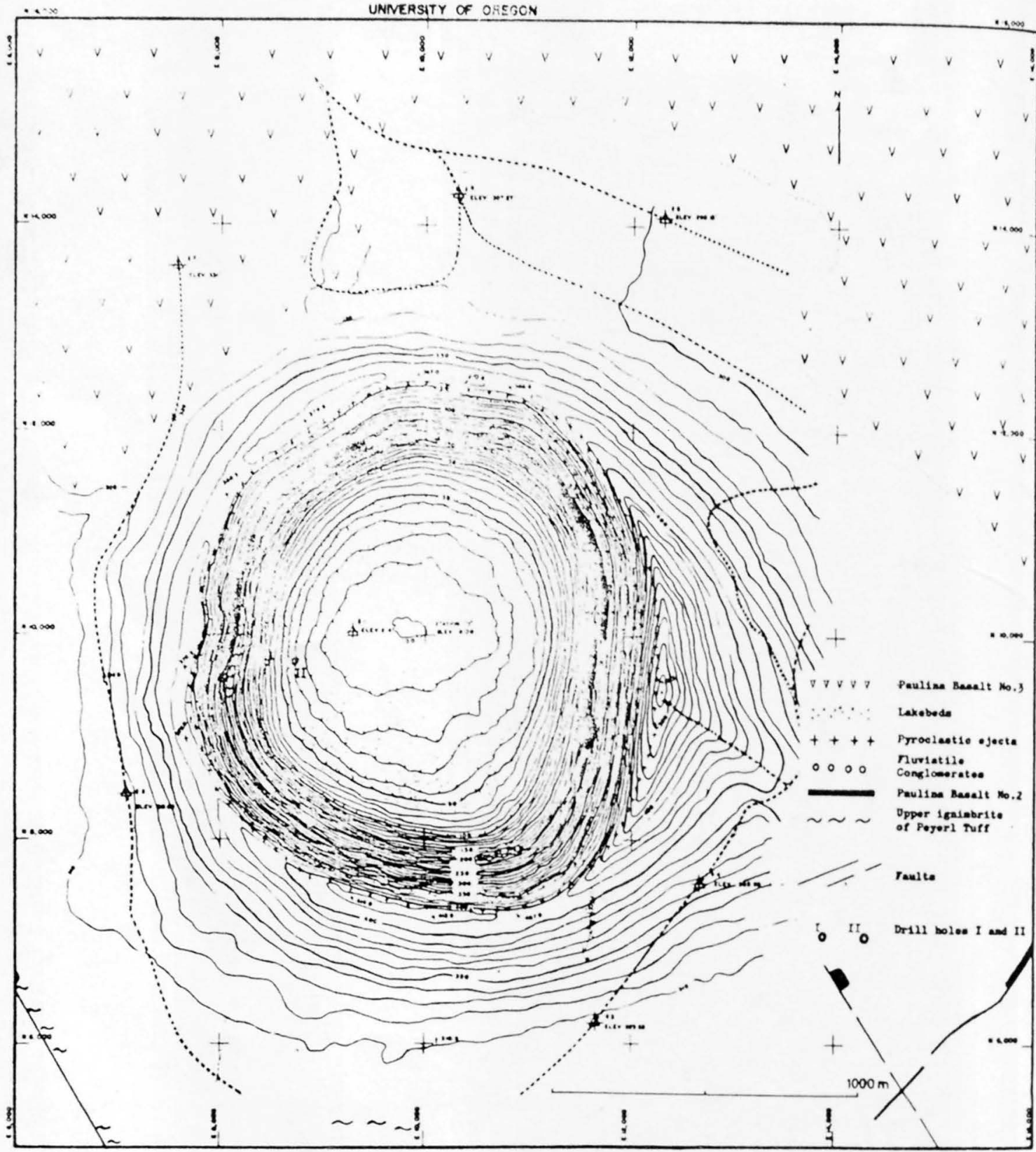

Figure 5: Topographic and geologic map of Hole-in-the-Ground. Contour interval is ten feet. Field control by J. W. Hawthorne. 


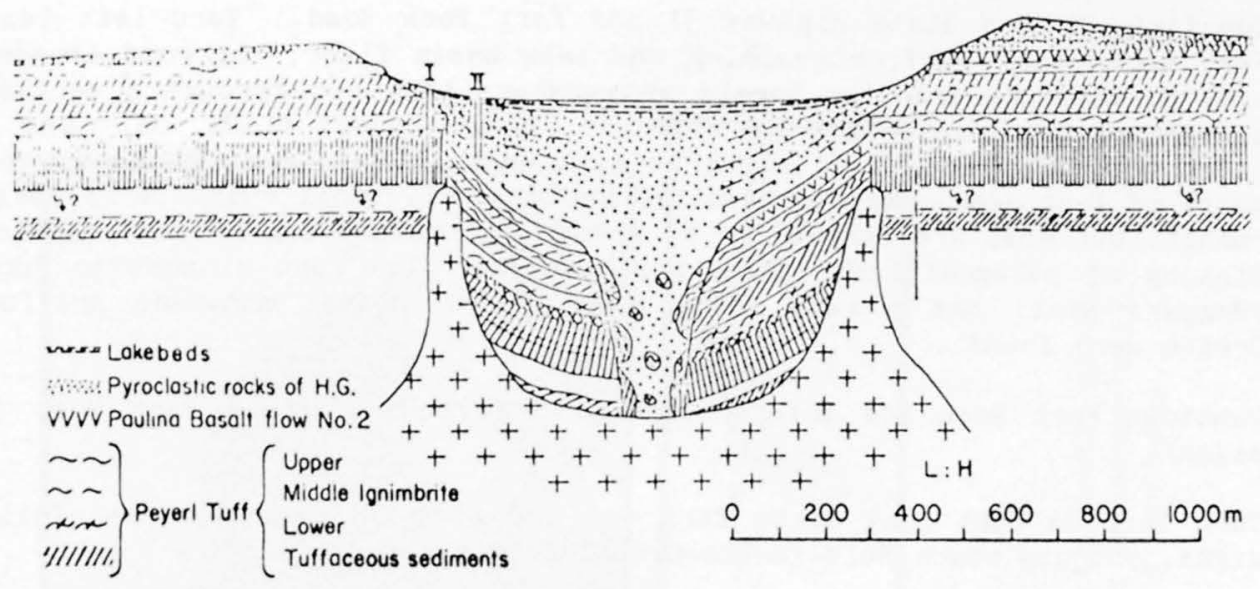

xuva Porphyrific bosolf, type 4

thatituly Porphyritic bosalt, type 3

שx:s Finograinod basalt, type 5

I,II Drillhole No. I, No. II

${ }_{+}{ }^{+}$Intrusive basalt

Figure 6: Geologic section through Hole-in-the-Ground based on surface exposures, drill holes and geophysical data. Interpretation by Lorenz (1971).

and velocities during intervening, less violent stages were in the range of 200 to 250 bars and about 130 meters per second.

The kinetic energy released during the most violent eruptions was approximately $9 \times 10^{20}$ ergs and the seismic events that must have accompanied these explosions had a magnitude of about 5. Ejecta 10 centimeters in size were thrown to heights of 2 to 3 kilometers and the eruption cloud may have reached 5 kilometers or more. The axis of eruption was slightly inclined toward the southeast; the form of the vent seems to have had a more important influence than wind. Base surges that accompanied some of the explosions left deposits of vesiculated tuff.

The total energy derived from the basaltic magma was of the order of $5.7 \times 10^{23} \mathrm{ergs}$. Most of this energy went into heating of ground water and the enclosing country rocks; only a small part, possibly a tenth was released by expansion and vaporization of the water and mechanical processes, such as crushing, acceleration and ejection of debris.

Geophysical measurements indicate a domical intrusion below the crater floor and extending upward as a ring dike around the margins of the crater."

Return to State Highway 31.

$(1.7)$

26.8

26.8 to

28.2
Picnic grounds on right.

Section (top to bottom) through (1) basalt flow (from flanks of Newberry Volcano?) and (2) Peyerl Tuff; a section consisting of $4.0 \mathrm{~m} . \mathrm{y}$. old pyroclastic flows and tuffaceous sediments. The section is exposed along Highway 31 in road cuts. If you stop, please leave your auto at the top of the hill in the picnic grounds and stay on the edge of the road; there are numerous fastmoving logging trucks on this highway! 
(0.9)

Junction, Oregon State Highway 31 and Fort Rock Road. Turn left (east) on Fort Rock road. Before reaching the lake basin floor, the road crosses several north-south trending horsts and grabens that cut through a section consisting of the Peyerl Tuff and Pliocene (?) age basalt flows. On the left (north) of Fort Rock road along an east-west line to Fort Rock are the remnants of four deeply eroded basaltic vents. Only small remnants of lava lakes remain, but most are surrounded by aprons of rounded cobbles and pebbles consisting of palagonitized hyaloclastic tuffs. The vent closest to Fort Rock (Beggars Heel) has a cave where some of the oldest man-made artifacts in Oregon were found.

$(6.4)$

35.5

Downtown Fort Rock and intersection with Fort Rock State Park Road (follow signs).

$(0.1)$

35.6

(0.5)

36.1

Turn left to Fort Rock State Park (if you stay on this road and follow the signs, you can reach Hole-in-the-Ground from the east side).

Fort Rock

Fort Rock, with its spectacular wave-cut cliffs, is an isolated maar volcano within a monotonous, flat lake basin (Peterson and Groh, 1963). The wave-cut remnant is $1360 \mathrm{~m}$ in diameter and $60 \mathrm{~m} \mathrm{high}$, and the present crater floor is 6 to $12 \mathrm{~m}$ above the floor of the lake basin. The south rim has been breached by waves of the former lake, providing easy access to the crater. A wave-cut terrace occurs $20 \mathrm{~m}$ above the floor of Fort Rock Valley (Fig. 7).

The maar is composed of orange-brown lapilli-tuff in beds of $1 \mathrm{~cm}$ to $1 \mathrm{~m}$ thick that can be traced from within the crater to the outer flanks. Graded beds with accretionary lapilli are common.

Inward-dipping beds are parallel to the crater walls (Fig. 7) and suggest that the crater is funnel shaped; the innermost beds dip inward at angles of 20 to 70 degrees. On the west side of Fort Rock is a distinct angular unconformity where the deposits, truncated by slumping into the crater, are plastered with younger beds. These younger beds are part of a continuous pyroclastic sequence on the outer flanks. An incipient slump is visible on the east flank where the sequence is in-place with quaquaversal dips away from the rim crest; fracture planes associated with the slump, dip inward at 40 degrees, the same angle as the surface of the unconformity on the opposite side of the crater.

Fort Rock is typical of most of the smaller, isolated maars of the Fort Rock-Christmas Lake Valley basin, such as Table Mountain, Flat Top, Lost Forest, Green Mountain SW and Green Mountain S (Fig. 2).

$(7.00)$

43.1

Return to junction of Fort Rock Road and Highway 31 and turn left (south), down Highway 31 toward Silver Lake.

An alternate route, from the center of downtown Fort Rock, is south along Lake County Road 513. This is a gravel road that is a short-cut to Silver Lake, but the bridges will not support heavy trucks or buses. If you take this alternate route of 16.5 miles, you will go between a north-south trending normal fault (west) and the Connley Hills (east). As you leave the lake basin, near junction with County Road 510-C you will see the northern end of the Connley Hills, a line of domes of intermediate composition. Remnants of a small maar are plastered onto the northernmost dome, near the former lake shoreline. South of the Connley Hills is Hayes Butte, a basaltic shield. These volcanoes stood as an island in the lake that was present here during late Pliocene-Pleistocene time.

To the west, several broad, older (Pliocene) maar volcanoes are exposed in a low ridge, partly buried by basalt flows. a gravel road to the west (turn right, 5.3 miles south of the town of Fort Rock) crosses one of these maars. It is on private land, however. Please ask for permission to enter before doing so. 


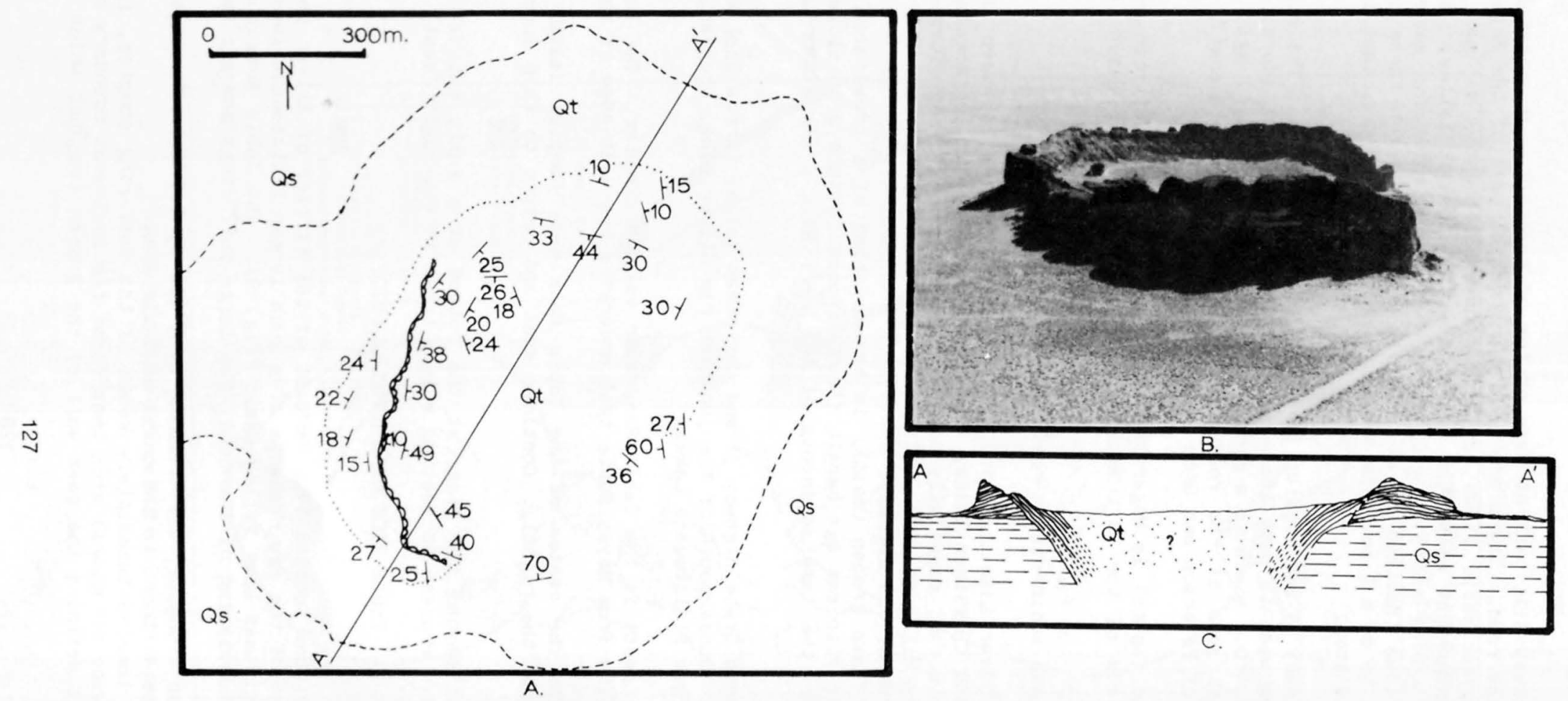

Figure 7: Fort Rock tuff ring. A. MAP. Qs - Pleistocene lake sediments, mostly diatomites. Qt - tuffs, lapilli-tuffs and tuff breccias. Scalloped line is an unconformity. Dotted line is the cliff edge. B. Oblique aerial photograph, from the southwest. C.
Cross-section. 
After crossing a small divide, you will enter Paulina Marsh; no outcrops until you reach the intersection with Highway 31 near Silver Lake.

$(0.4)$

43.5

(3.1)

46.6

$(9.4)$

56.0

$(2.8)$

58.8

$(1.9)$

60.7

$(6.4)$

67.1

(2.0)

69.1

(2.0)

71.1

(1.1)

72.2

Road cut (Highway 31); park at base or top of road cut. Be careful; stay on the side of the road. There are good exposures of part of the Peyerl Tuff, a sequence of pyroclastic flows and interbedded sediments, as much as $150 \mathrm{~m}$ thick, that crops out along the west side of Fort Rock Valley. Radiometric ages of $4.47+0.84$ and $3.35+0.44 \mathrm{~m} . \mathrm{y}$. were determined for several of the pyroclastic flows (Macleod et al., 1976). The source for these pyroclastic units appears to be a 7 to $10 \mathrm{~km}$ wide caldera near Wart Peak, that is about 15 $\mathrm{km}$ WSW of this stop.

Junction, Highway 31 and Wickiup Springs - Stams Well Road. The ridge on the horizon to the west is near the east rim of the Wart Peak Caldera, identified by N. MacLeod. Due south is a cinder cone of late Pliocene(?) age.

On the east side of the road is a poorly exposed Pliocene(?) maar, the Wastina Maar of Peterson and Groh (1963).

Straight ahead (south) is Hager Mountain, a $5.9 \mathrm{~m} . \mathrm{y}$. old silicic dome on the southwestern rim of the Fort Rock - Christmas Lake Valley Basin (MacLeod et al., 1976).

Exposure of lake sediments in road cut (Highway 31 ).

Town limit; Silver Lake. As you drive along Highway 31 between the town of Silver Lake and Christmas Valley Road, note the wave-cut terraces and notches along the basin rim, especially northward around the "island" formed by Hayes Butte, Connley Hills and the Table Rock Maar Complex. The maars are straight ahead and north of the highway.

The Silver Lake graben (south) is the keystone of a broad arch broken by normal faults; Pliocene age basalt flows exposed in this arch slope northward into and under the lake sediments of the Fort Rock - Christmas Lake Valley Basin.

Junction, Oregon State Highway 31 and Christmas Valley (Arrow Gap) Road. Turn left (north). Dunes south of the junction rim Silver Lake, the marshy remnant of a much larger Pleistocene Lake.

On the right (east) is the Table Rock maar volcano complex. The lowest cliff is a basalt flow from Hayes Butte that underlies the west edge of the complex.

Dirt road into the center of the Table Rock maar complex leaves the paved county road (to the right). Continue east and return to this junction after visiting stop A.

Stop A. Just beyond the pass, at the bottom of a gully cut into the maar complex, stop. Proceed on foot up a jeep trail to the right (east).

TABLE ROCK MAAR COMPLEX (STOP 2)

\section{General Description}

Table Rock is a tuff cone located $14.5 \mathrm{~km}$ east of the village of Silver Lake, on the shore of Silver Lake, one of the few remnants of a much larger Pleistocene lake that once filled the Fort Rock-Christmas Lake Valley Basin (Fig. 2). The Table Rock tuff cone is part of a maar complex consisting of the cone, two large tuff rings and six smaller tuff rings or eroded vents.

This complex forms an elongate, NNW-trending oval 5.6 by $8.8 \mathrm{~km}$. The highest point, about $395 \mathrm{~m}$ above the basin floor, is the crest of Table Rock.

Silver Lake graben, located immediately south of the tuff-ring complex, is the keystone of a broad 25-km-wide structural arch that forms the southwest boundary of the lake basin. The normal fault defining the east wall of the graben (through which Highway 31 


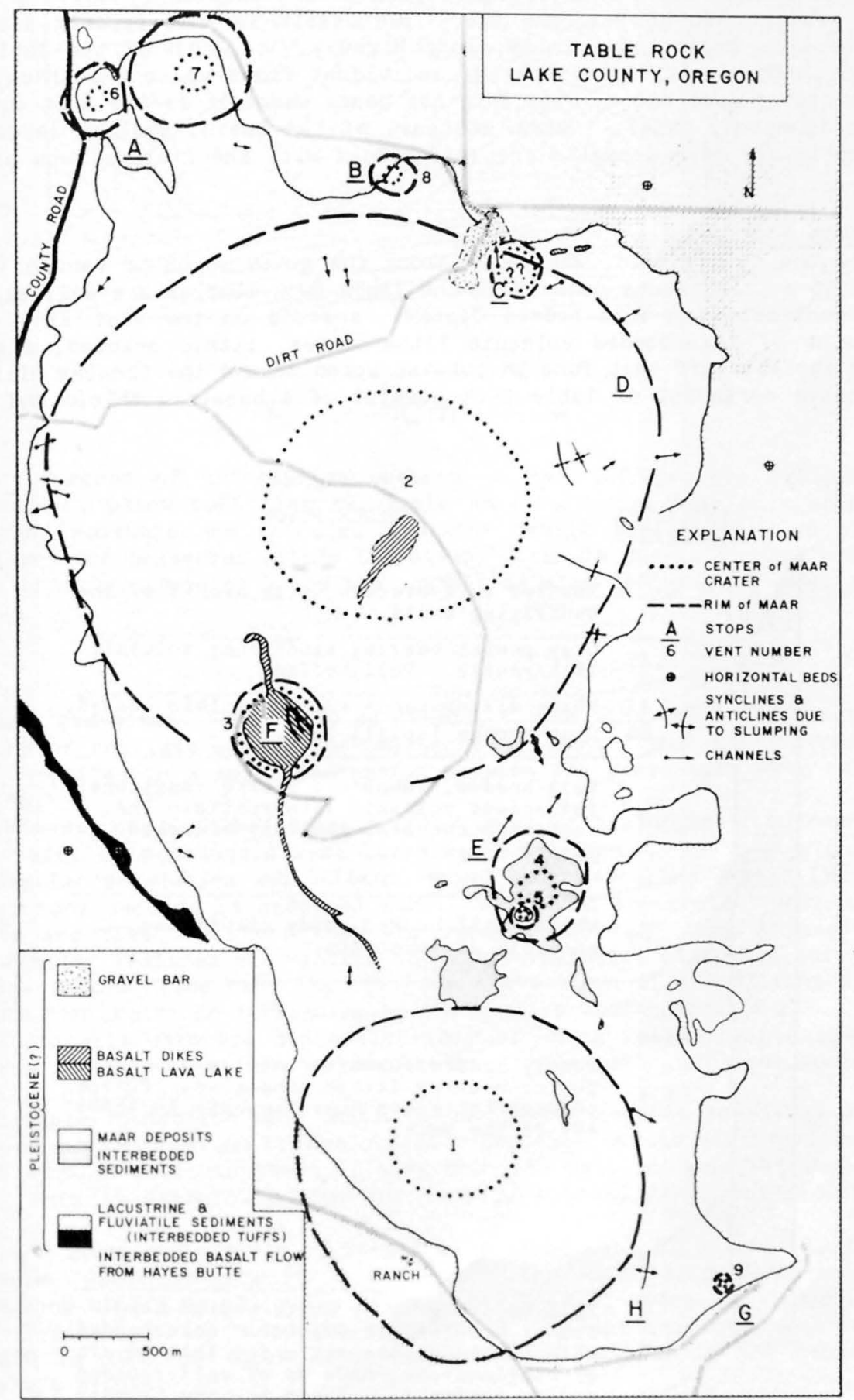

Figure 8a: Table Rock tuff ring complex. 
continues over Picture Rock Pass) is parallel to the long axis of the maar complex and possibly lies beneath it. The fault, however, does not cut any of the tuff deposits.

The tuff ring complex overlies a $220 \mathrm{~m}$ thick section of lake sediments and interbedded tuffs, and sands and gravels derived from the Connley Hills. These predominantly lacustrine sediments overlie the Picture Rock Basalt (Hampton, 1964), a feldspathic diktytaxitic basalt unit of Pliocene age. The basalt is well-exposed along the southern edge of the lake basin, especially along Highway 31, south of the Table Rock Complex. The Picture Rock basalt, consisting of individual flows up to $9 \mathrm{~m}$ thick, with an aggregate thickness of over $230 \mathrm{~m}$, dips into the basin where it is the main aquifer tapped for irrigation (Hampton, 1964). South and east of the basin, shallow lacustrine and flood plain deposits and maar deposits are interbedded with the Picture Rock basalt (Walker et al., 1967).

Stop A, table Rock Complex

Park on the county road, walk east along the gully south of vent 6 (bluff on north) for about $350 \mathrm{~m}$. Sediments underlying the Table Rock Complex are well-exposed here (Fig. 8). In contrast with well-bedded diatomites found on the east side of the complex, these consist of interbedded volcanic litharenites, lithic arkoses, diatomaceous siltstones and lapilli-tuff that form an outwash apron around the Connley Hills. The Connley Hills, located northwest of Table Rock consist of a basaltic shield and intermediate to

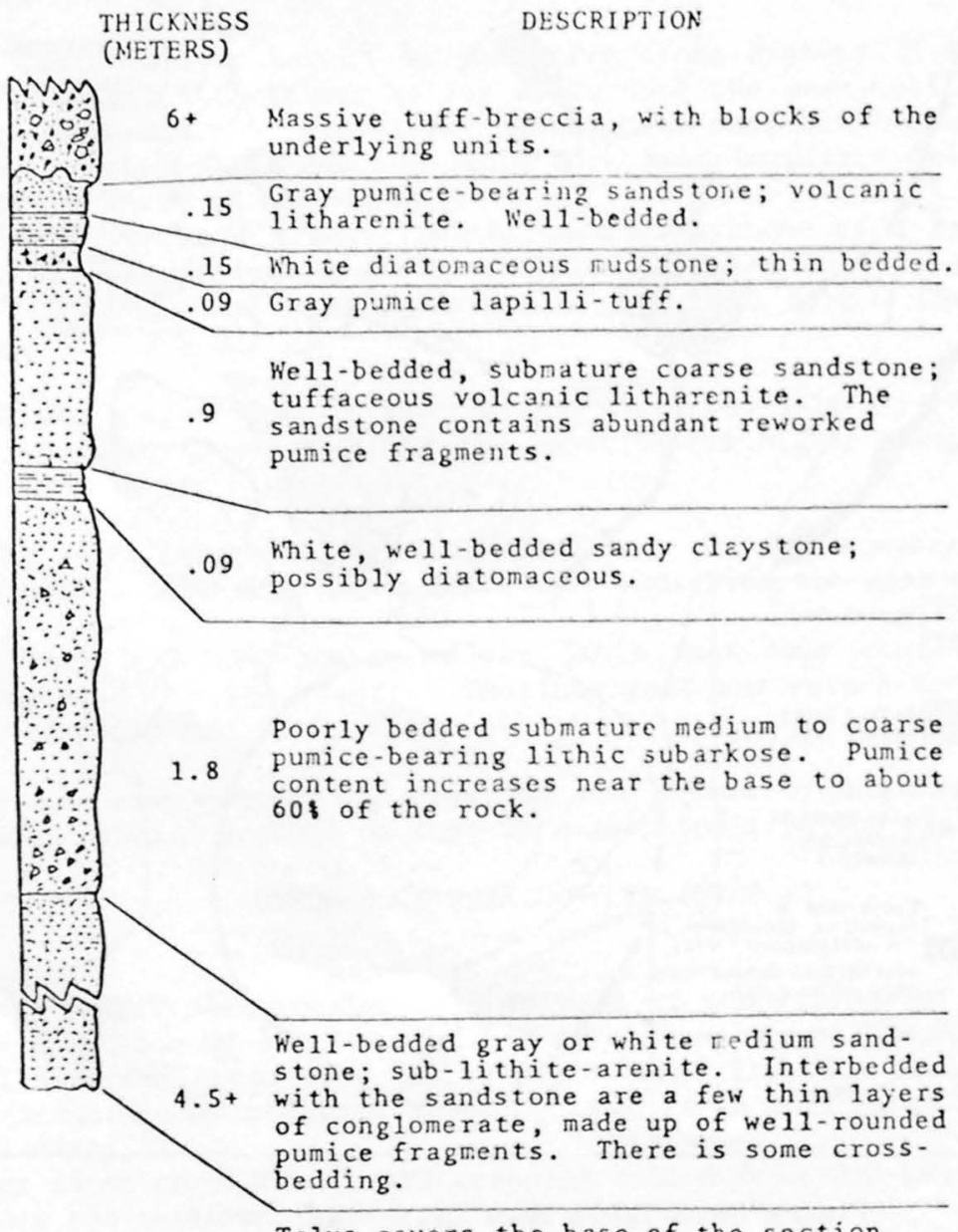

Talus covers the base of the section.

Figure 80: vection of sediments exposed under the northwest corner of the Table Rock tuff ring complex. 

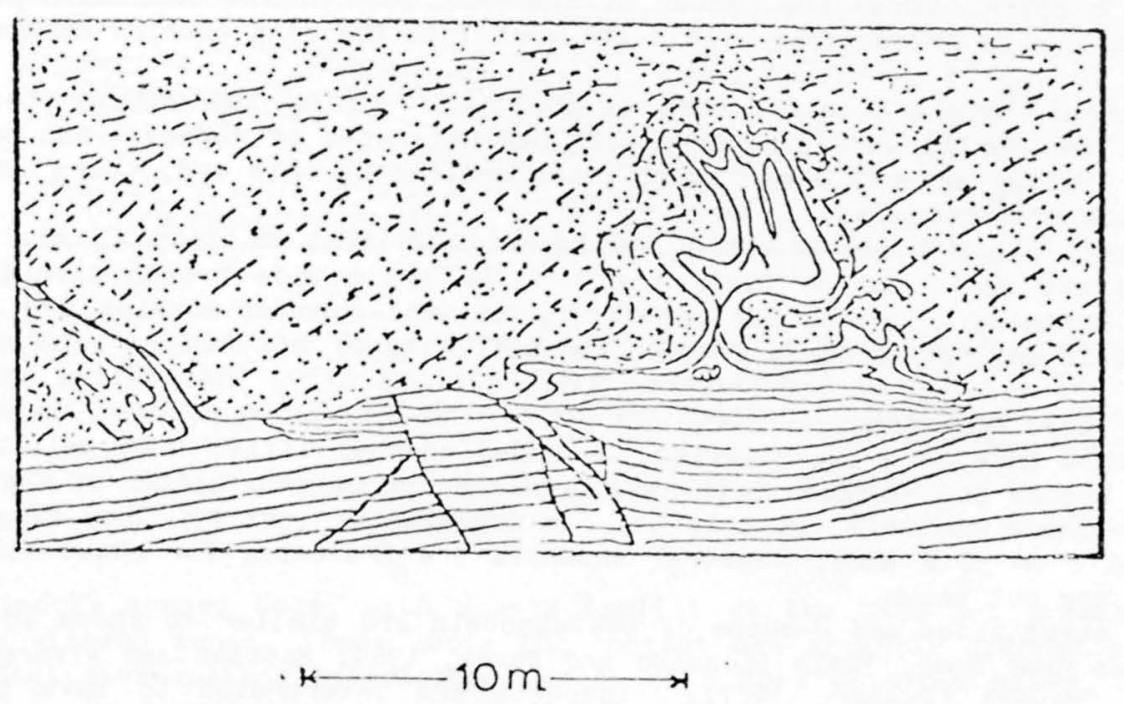

Figure 9: Diagram of doformation pattern at the tuff-breccia (stippled) - sediment (plain) concict, below tuff ring $\left.\right|_{2}$, table Rock tuff ring complex. Uppermost layers of sandstone and mudstone are intruded into the basalt tuff-breccia as dikes. Deformed bedding planes are preserved within the dikes, although nearly pinched off where the dike enters the breccia. Bedding, below the contact is also deformed by small scale faults.

silicic domes and flows. They were an island, $6.4 \mathrm{~km}$ wide and $19 \mathrm{~km}$ long, throughout the late history of the lake basin. The sediments are higher than those of the basin and may have been deposited in a small depression between the large tuff ring (2) and the hills to the north.

The sediments are deformed beneath thick units of hyaloclastic tuff-breccia and penetrate the tuffs as mudstone dikes; the dikes vary from $<2 \mathrm{~cm}$ to $3 \mathrm{~m}$ thick. They have sharp, irregular boundaries and bulbous, ovoid and sheet-like shapes (Fig. 9). The entire sedimentary section is deformed here. Away from the contact with the tuff breccia these units are flat, but here they dip beneath the tuff ring at angles of 30 to 40 degrees. Similar features are visible in finely-laminated diatomite beds under the 7-mile Ridge Complex (see map, Fig. 2). It isn't known if the tilting is due to subsidence around the crater or to loading by the massive tuff-breccia.

The plastically deformed sediments, many of which retain original bedding features within dikes, suggest that the sediments were water-saturated when buried by the overlying massive hyaloclastic breccias.

The unstable foundation upon which the tuff-ring complex rests may also account for some large-scale deformation of hyaloclastic deposits on its eastern flank. Broad anticlines and synclines within the tuff ring deposits may, in some instances, be caused by slumping. This is especially true for vent 2, a broad ring with deposits up to $120 \mathrm{~m}$ thick.

The bluff immediately north of Stop A is part of vent 6, a small tuff ring about 240 $m$ in diameter with deposits $25-30 \mathrm{~m}$ thick. The outer slopes of the ring have been eroded, leaving cliffs on all sides except the SW edge, where its deposits lap onto tuff ring 2. Typically, the deposits consist of well-bedded, yellow-brown sideromelane lapilli-tuff in 1-60 cm thick beds. About five percent of the deposit consists of angular basalt blocks.

Stop B, Table Rock Complex

A small vent and tuff ring (vent 8) exposed in cross-section along the cliff cuts hyaloclastic tuff and tuff-breccia of the tuff ring 2. The vent is about $33 \mathrm{~m}$ in diameter; the tuff ring remnant has a radius of $120 \mathrm{~m}$. The vent has vertical walls and is 
filled with near-vertical, concentric beds of yellow-brown sideromelane lapilli-tuff, 3 $\mathrm{cm}$ to $2 \mathrm{~m}$ thick. Near the center of the vent some of the beds have slumped (Fig. 10). Some beds can be traced from within the vent into the ring located on the surface of tuff ring 2 .

Vertical beds are interpreted as follows: during the waning phases of activity, vertical vent walls were plastered with bed after bed of cohesive ash until the vent was filled. Unlike several other small vents similar to this one, there is no central core of massive tuff-breccia.

Between Stops B and C there are wave-cut cliffs; at Stop C, the wave-cut feature breaches the north end of tuff ring 2. The $120 \mathrm{~m}$ wide breach through which the road passes, contains a gravel bar consisting of well-rounded cobbles and pebbles of palagonite tuff and tuff-breccia eroded from tuff ring 2.

\section{Stop C, Table Rock Complex}

Visible here is a steep-walled, U-shaped channel filled with well-bedded tuff. The channel trends and plunges north away from the approximate center of vent 2 . This is one of 23 U-shaped channels cut into the rim deposits of vent 2. They range from 1 to $21 \mathrm{~m}$ deep and 2 to $30 \mathrm{~m}$ wide. Several channels are traceable for about $150 \mathrm{~m}$, but original lengths are not known.

The steep sides and U-shape of the channels are similar to those in deposits of maar volcanoes near Rome, Italy (Losacco and Parea, 1969; Mattson and Alvarez, 1973) and Koko Craters, Hawaii (Fisher, 1977). Channels are interpreted to have been cut by base surges. Infilling beds, which thin and curve up against channel sides with some extending over the sides onto the rim beds of the tuff cone, were deposited by base-surge flows and by air-fall. The absence of consolidated palagonite tuff cobbles within the channels indicates that they were cut prior to palagonitization and induration of the tephra.

East of the channel, along the inside rim of vent 2, the effects of palagonitization on hyaloclastic tuffs are well shown. Well-bedded sideromelane tuffs have been hydrothermally altered to massive, featureless orange-brown to dark brown, brittle palagonite tuff. The contact between slightly palagonitized bedded rocks and hydrothermally palagonitized tuffs is sharp; it is irregular and crosses bedding planes (Fig. 11). Only

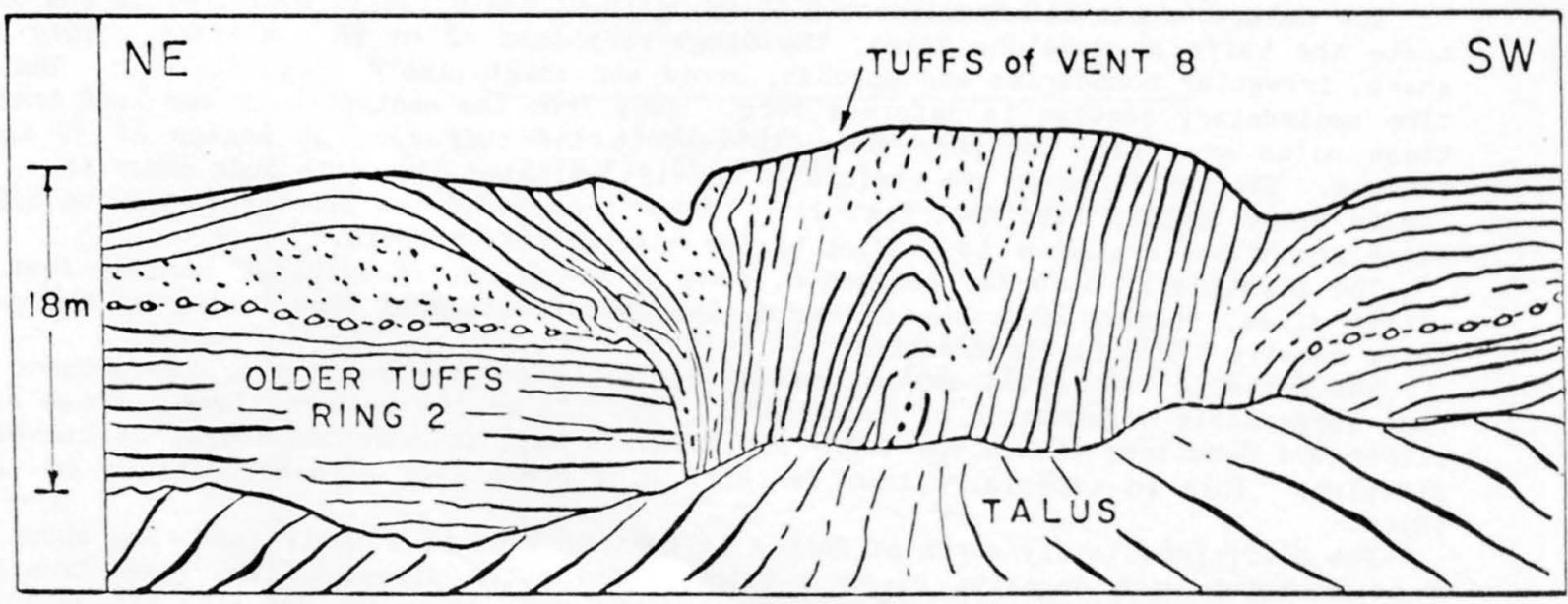

Figure 10: Sketch of the cliff face in which vent 8, Table Rock tuff ring complex, is exposed. Heavy dots outline the ground surface prior to the eruption of vent 8 . A remnant of a small tuff ring around the vent is visible. 


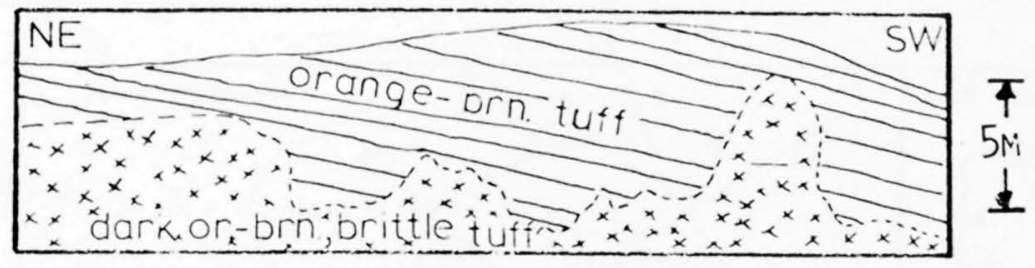

Figure 11: Bedding within the Table Rock maar complex is often destroyed by palagonitization of the well-bedded tuffs by late-stage hydrothermal activity. The dotted line traces the contact between partly palagonitized and completely palagonitized tuff.

the most distinctly graded beds, with coarse lapilli at the base are preserved in the hydrothermally altered zones. Beds above the contact are slightly altered sideromelane tuffs; individual sideromelane pyroclasts consist of a core of brown glass, rimmed with orange or yellow-orange palagonite. Some pyroclasts, especially smaller ones, are completely altered, but their relict forms are preserved. There are also traces of zeolite and calcite cement between pyroclasts.

Below the hydrothermal contact, sideromelane pyroclasts are completely altered to palagonite, and the rock is crossed by dessication(?) cracks that break it down into 10 to $40 \mu \mathrm{m}$ particles. With the "homogenization" of the rock, grain size differences responsible for visibility of bedding and sedimentary structures are destroyed. The end product is a massive, brittle rock composed of clays, zeolites, iron oxide and calcite cut by NW-trending to W-trending joints (vertical).

Massive, altered areas within craters suggests that the alteration is due to reaction of sideromelane pyroclasts (basaltic glass) with steam seeping through ejecta. This process is being observed at Surtsey, Iceland (Jakobsson, 1978).

Stop D, Table Rock Complex

Continuing east and then south to the rim of vent 2, then back down to the central crater area, many physical characteristics of maar volcanoes may be seen, including planar graded and reversely graded lapilli-tuffs, cross-bedding (with current directions uphill, out of crater), bedding plane sags (block sags), and convolute beds.

\section{Stop E, Table Rock Complex}

Park vehicles near the base of Table Rock and walk southeast about $500 \mathrm{~m}$ to the edge of a depression about $45 \mathrm{~m}$ deep and $360 \mathrm{~m}$ in diameter and open to the lake basin on the east side. The area, designated as vent 4, formed a crater in tuffs of vents 1 and 2 , with crater walls sloping inward at angles of 30 to 85 degrees. Parallel to and covering the crater walls are well-bedded, steeply dipping layers of lapilli-tuff, with an aggregate thickness of $60 \mathrm{~m}$ (Fig. 12a). Yellow-brown lapilli-tuff and tuff-breccia are present in beds ranging in thickness from $1 \mathrm{~mm}$ to $1 \mathrm{~m}$. These beds dip steeply within the vent and may be traced out of the vent onto the remnants of a small maar deposit overlying tuffs of vents 1 and 2 (Fig. 12b). Wet, sticky hyaloclastite tephra were plastered onto crater walls during the waning phases of the eruptive activity; many have remained in place, but some sections have slumped and overturned.

Lake sediments consisting of white diatomaceous mudstones occur within the crater of vent 4. These deposits lie nearly $30 \mathrm{~m}$ above the lake basin floor and were deposited in a crater lake apart from the larger basin.

Within the southern part of the crater of vent 4 is a prominent oval column of tuff (18 $\mathrm{m}$ high, $90 \mathrm{~m}$ long) that may have been the conduit for a small vent (5) (Fig. 13a). The column consists of concentric, steeply dipping tuff beds that cut across and therefore are younger than the crater lake sediments of vent 4 . Within $2 \mathrm{~cm}$ of the tuff-lake sediment contact, the flat-lying lake sediments are brittle, (affected thermally by the hyaloclastic tephra of the conduit?) Beds of sideromelane tuff and lapilli-tuff dip 


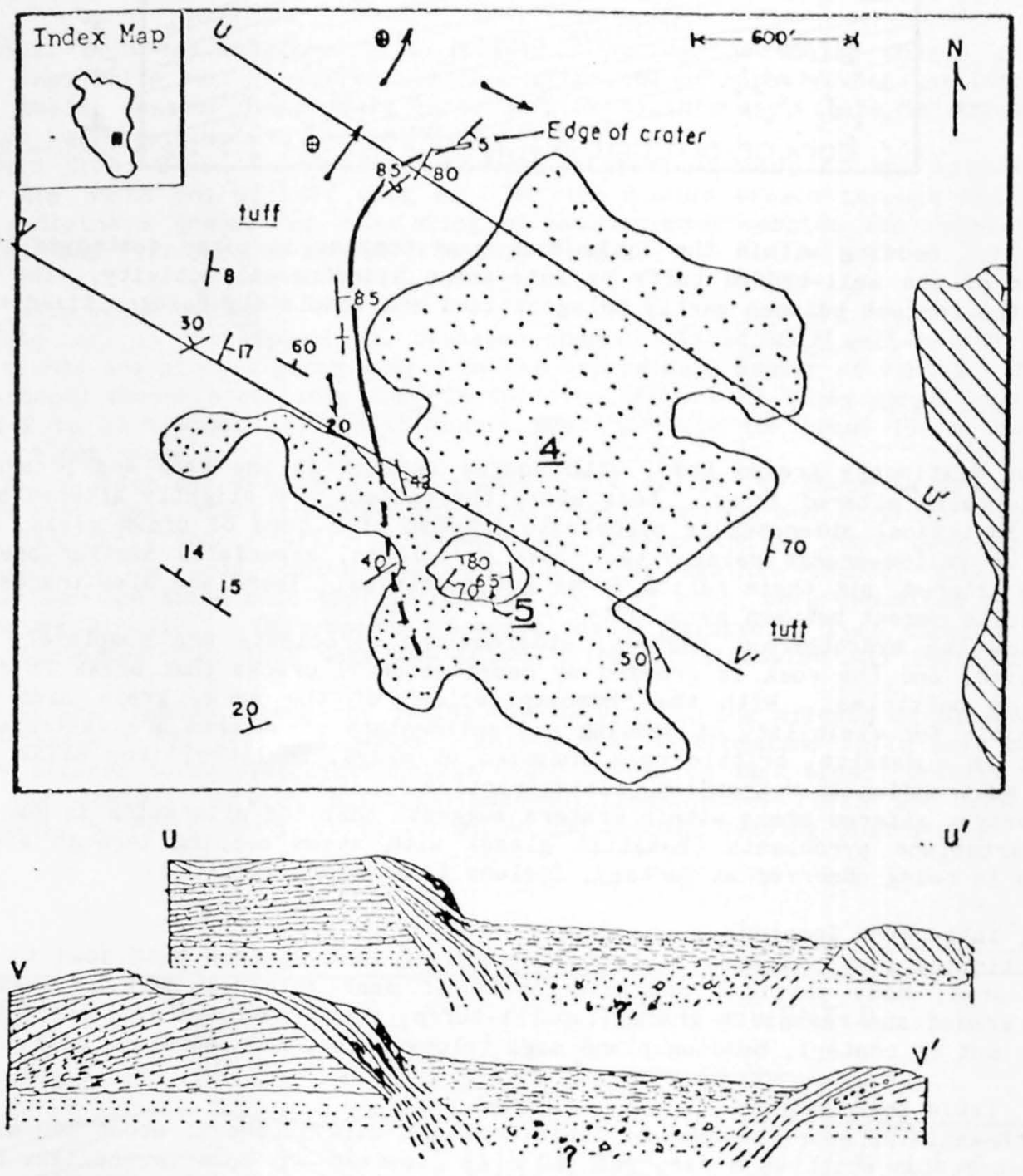

Figure 12a: Sketch map of vent areas 4 and 5, Table Rock tuff ring complex. The map is represented on the index map (inset) as a black square. An outline of the Table Rock tuff ring complex is shown in the index map. The present crater edge of vent 4 is shown with a double line. Plain areas are bedded tuffs, stippled areas are crater lake sediments and alluvium, diagonal lines represent lake sediments of the Fort Rock Christmas Lake Valley Basin. Vent 5 is located at the south edge of the crater of vent 4.

Figure 12b: Cross-sections $U-U^{\prime}$ and $V-V^{\prime}$. The alternating stipple-line pattern represents bedded tuffs of tuff ring 2, the continuous 1 ine pattern represents bedded tuffs of represent lake sediments underlying the tuff ring complex. 


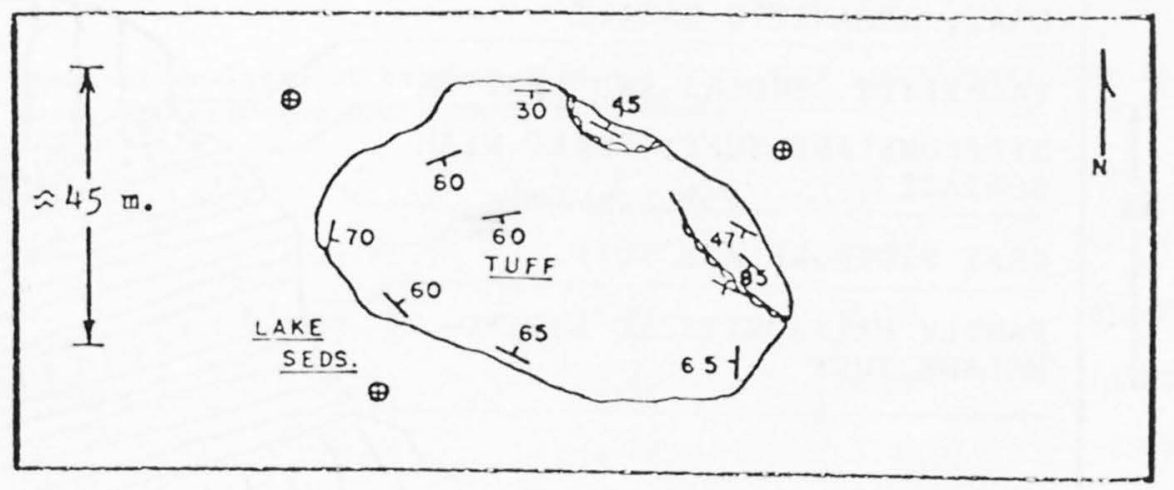

Figure 13a: Sketch map of vent area 5, Table Rock tuff ring complex. Scalloped lines represent the most pronounced unconformities, with the scallops on the upper beds. The oval, concentric arrangement of the bedding is shown by the arrangement of attitudes.

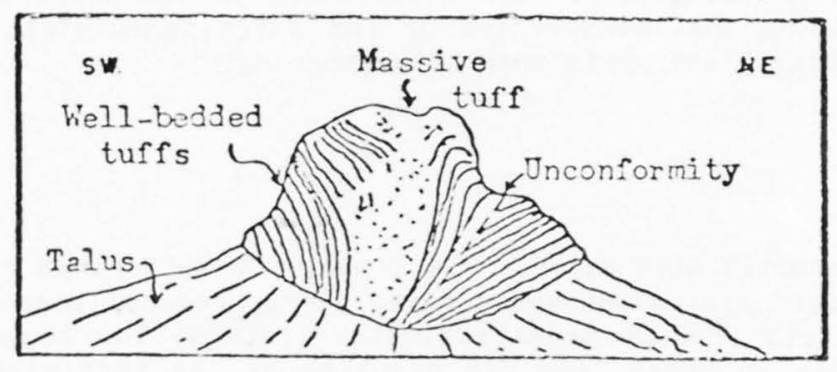

Figure 13b: Field sketch of the southeastern end of vent area 5 .

inward from the outer edges of the conduit of vent 5 at angles of 30 to 80 degrees (Fig. 13). The center of the conduit consists of massive tuff breccia containing blocks of lake sediment. As at vent 8 (Stop B) and vent 4, concentric beds with steep dips suggests that cohesive tephra was plastered onto crater walls during (waning phases?) of explosive activity. The vents may have been progressively clogged with tephra, somewhat analogous to clogging of pipes with grout.

Stop F, Table Rock Complex

Proceed up the dirt and gravel road to the top of Table Rock. Table Rock is an erosional remnant of a tuff cone constructed above lake level on the southern rim of vent 2 . At present it is a symmetrical cone about $1530 \mathrm{~m}$ in diameter at the base, tapering to a diameter of about $360 \mathrm{~m}$ at a height of $360 \mathrm{~m}$ above the surrounding plain. The cone is capped with flat-lying basalt which once filled the crater, but erosion has modified the original cone, exposing the once-ponded basalt lava lake (Fig. 14). Dikes extend north and SSE of the crater lake, parallel to the long axis of the tuff ring complex.

On the lower flanks of the cone, the rocks are mostly hyaloclastic tuffs; yellowbrown or orange sideromelane and palogonite lapilli-tuff occurs in $1 \mathrm{~mm}$ to $2 \mathrm{~m}$ thick beds. Near the summit, the uppermost hyaloclastites are overlain by 1.5 to $6 \mathrm{~m}$ of massive black or red cinders and bombs from fire-fountaining (Strombolian eruption) that preceded the filling of the crater with lava (Fig. 15).

The lava lake is vertically jointed high-alumina basalt (Table 1). Blocks of the lava have slumped toward the east, leaving 2-3 $\mathrm{m}$ high scarps along NNW-trending fractures.

Why is the shape of Table Rock tuff cone different from the broad, low maars of most of the complex? A possible answer is the depth of explosive steam generation where 


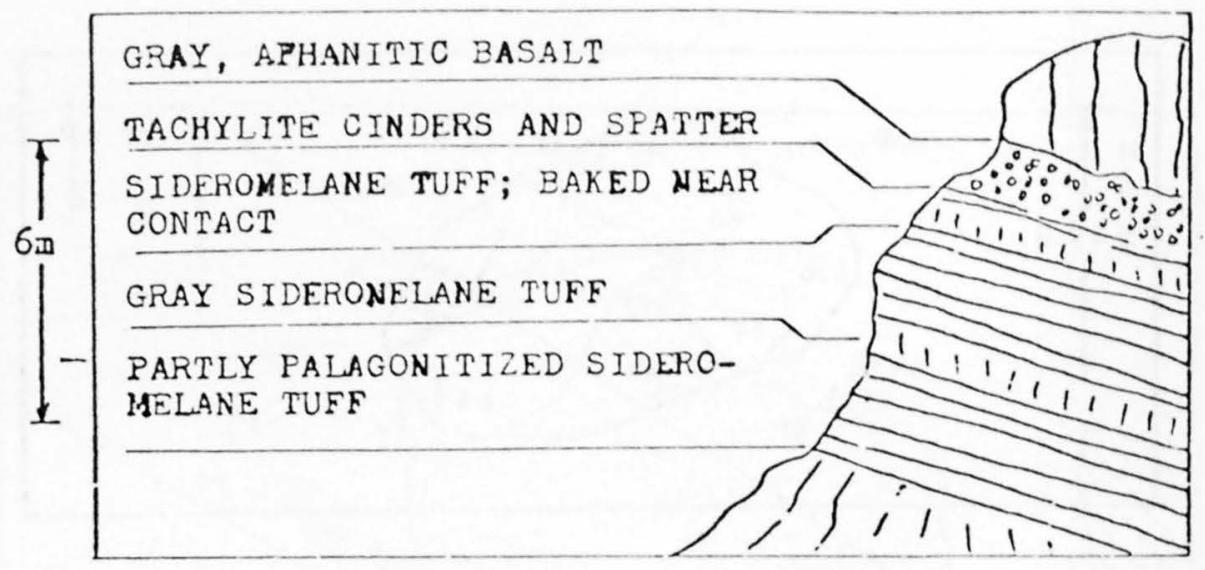

Figure 14: Section of tuff exposed below the lava lake on the west and south side of the Table Rock tuff cone. A zone of tuffs (sideromelane) immediately below the former lava lake is not altered to palagonite. Tuffs elsewhere in the tuff cone are partly altered to palagonite, implying that dehydration of the tuffs immediately below the lava lake decreases the instability and resistance to weathering.

ascending magma interacted with water. The broad, low tuff rings may have resulted from shallow phreatomagmatic explosions where magma nearly reached lake level. Shallow steam explosions would likely produce broad explosion craters, low fragment trajectories and base surges resulting in broad, low rim deposits of the tuff rings. The base of the Table Rock tuff cone is, however, located on the rim of vent 2 above former lake level. About $210 \mathrm{~m}$ below the cone base is a highly permeable aquifer within basalt flows which lies beneath essentially impermeable diatomite beds. In contrast with shallow explosions, phreatomagmatic explosions within the aquifer may have been guided by the conduit, resulting in higher angle trajectories and a higher, steep-sided cone.

There is an excellent view of the entire complex and the Fort Rock-Christmas Lake Valley basin from the top of Table Rock:

South - The edge of the basin, consisting of normally faulted Picture Rock Basalt of Pliocene age (Hampton, 1964). Silver Lake is located within a graben that is the keystone of a broad arch. The Table Rock Complex is situated along one of these normal faults, but not cut by it.

Also visible are wave-cut terraces and beach deposits that border the basin at an elevation of $1336 \mathrm{~m}$. The lake basin is about $64 \mathrm{~km} \mathrm{long}$ and $40 \mathrm{~km}$ wide, with numerous islands such as Hayes Butte and the Connley Hills, NW of Table Rock. The lake probably existed from mid(?) Pliocene to late Pleistocene time. During that period, eruptions of basaltic magma along normal faults that cut across the basin produced maars within and immediately adjacent to the lake and cinder cones and flows beyond the lake margins.

East - $13 \mathrm{~km}$ east of Table Rock and overlapping the basin margin is Seven-Mile Ridge, a NW-trending group of five overlapping maars. The complex is $12 \mathrm{~km} l o n g$ and $3.2 \mathrm{to} 4.8$ $\mathrm{km}$ wide. The best preserved maars are at the basin edge above the former lake level; they drape over a $61 \mathrm{~m}$ high fault scarp. The two northernmost maars have been eroded by wave action to flat-topped mesas, 9 to $18 \mathrm{~m}$ high.

Stop G, table Rock Complex

This stop, at the southern end of the table Rock Complex, is best reached by dirt roads from near the junction of State Highway 31 and the southern route to the village of Christmas Valley. Vent area 9, a small, tuff-filled conduit similar in size to vent 5 , crops out as a 6 to $9 \mathrm{~m}$ high knoll at the edge of a wave-cut terrace. It is about $30 \mathrm{~m}$ 
Table 1. Chemical analyses of basalts from the Fort Rock - Christmas Lake Valley Basin. $X-$ ray fluorescence analyses by $G$. Heiken.

Sample No.

1

$$
\mathrm{SiO}_{2}
$$

50.54

50.34

3

4

$\mathrm{Al}_{2} \mathrm{O}_{3}$

16. 18

15.67

50.67

52.39

$\mathrm{FeO}$ (total)

10.03

10.82

17.28

16.02

$\mathrm{MgO}$

6.63

8.08

10.87

8.49

$\mathrm{CaO}$

9.90

10.33

7.05

6.48

$\mathrm{Na}_{2} \mathrm{O}$

2.70

3.09

10. 12

9.73

$\mathrm{K}_{2} \mathrm{O}$

0.59

0.39

2.42

3. 33

$\mathrm{H}_{2} \mathrm{O+}$

0.2

0.0

0.39

0.86

$\mathrm{H}_{2} \mathrm{O}-$

0.2

0.3

0.0

0.8

$\mathrm{TiO}_{2}$

1. 37

1.68

0.6

0.6

$\mathrm{MnO}$

0.19

0.19

1. 37

1. 23

Total

98.53

100.9

0.19

0.16

1. Basalt flow in the lava lake of tuff cone 3, Table Rock tuff ring complex.

2. Lava Lake in the crater of the north tuff ring, Table Mountain.

3. Basalt from a dike which crosses the largest tuff ring in the Seven-Mile Ridge tuff ring complex.

4. Pahoehoe flow from Lava Mountain.

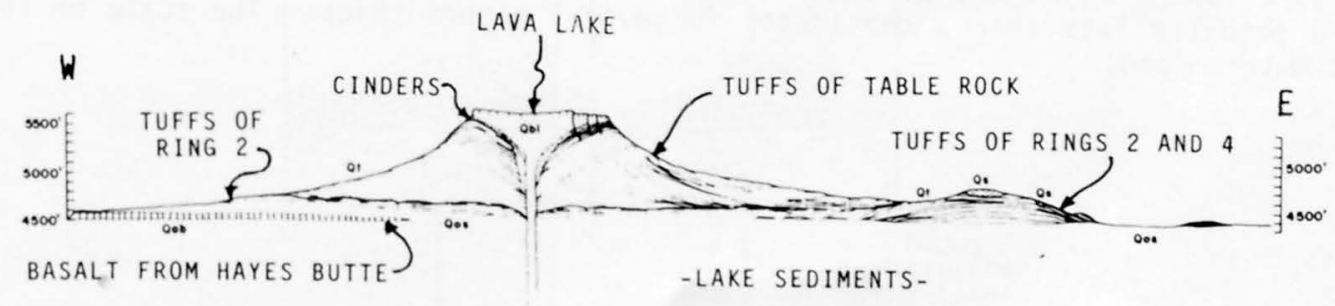

Figure 15: Cross-section, Table Rock. 


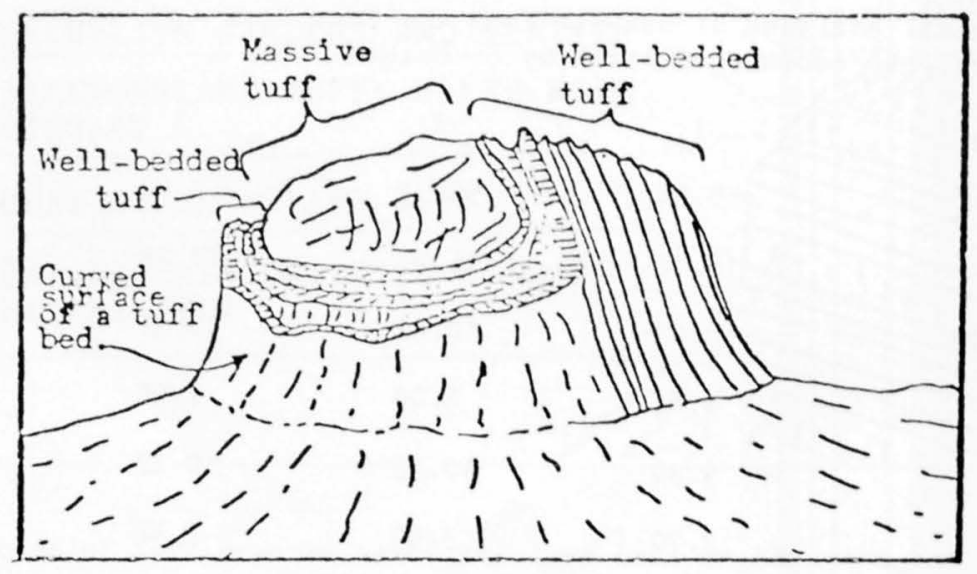

Figure 16a: Sketch of vent 9, Table Rock tuff ring complex, showing the concentric arrangement of tuff beds around the outer edges and massive tuff in the center. Stop G.

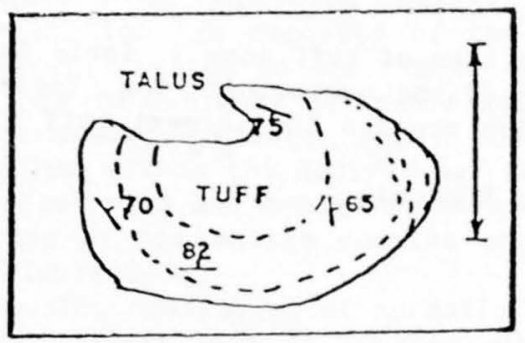

Figure 16b: Sketch map of vent 9. Dotted lines represent the geoemetry of beds which are actually less than a centimeter to several meters thick. The scale on the right is 30 meters long. 
in diameter. Tuff beds, $1 \mathrm{~cm}$ to $75 \mathrm{~cm}$ thick, are concentric and are plastered onto vent walls (walls now unexposed). The core of the vent is massive, palagonitized tuff (Fig. 16).

Stop $H$, Table Rock Complex

About $450 \mathrm{~m}$ west of stop G, on the southeastern flank of vent 1, only two ridges remain as erosional remnants of vent 1. These ridges $r$ ise about $95 \mathrm{~m}$ above the lake basin floor. Originally this maar may have been nearly $3 \mathrm{~km}$ in diameter.

The ring is composed of palagonitized sideromelane tuff, lapilli-tuff and tuff-breccia. The rocks form brownish-gray deposits on the outer flanks and ridge tops and orange-brown deposited within the crater. On the flanks, the tuff beds are in uniform, 1 to $2 \mathrm{~m}$ thick layers. Within the crater, however, hydrothermal activity has completely palagonitized and "homogenized" the tuff as is the case in vent 2 .

Deposits in some parts of ring 1 are deformed by slumping and are characterized by convolute bedding. The $61 \mathrm{~m}$ thick section of tuffs at stop $H$ are folded into a steep, overturned anticline in sharp contact with underlying, undeformed beds (Fig. 7). The glide plane for this slump is within the tuff sequence that dips outward (SE) from the vent at an angle of 6 degrees.

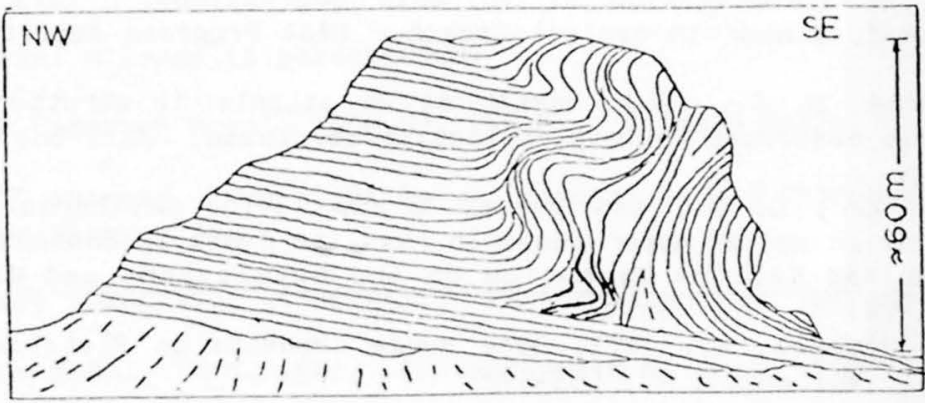

Figure 17a: Slump structure in bedded tuff on the east edge of Tuff Ring 1, Table Rock. Stop $\mathrm{H}$.

Figure 17b: (Below). Diagrams illustrating the history of events leading to the formation of the slump illustrated in Fig. 16b.

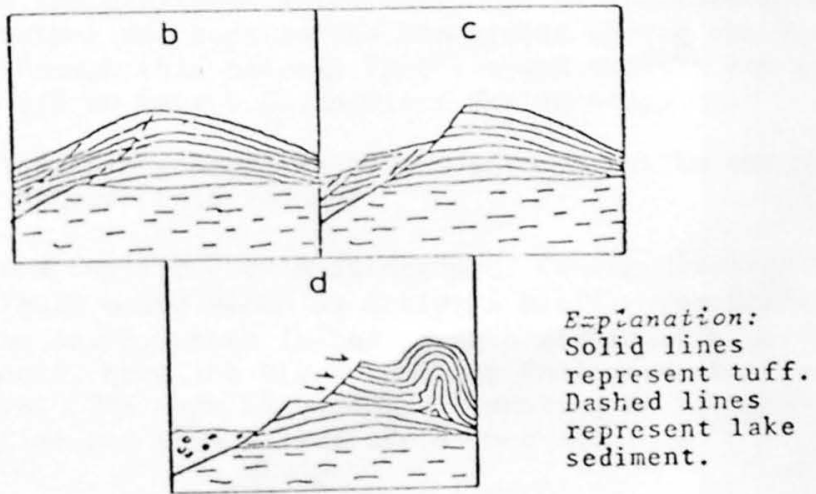

b. Formation of anticline-like structure typical of tuff rings by deposition of tuffs during eruption(s).

c. Masscs of bcdied tuff slump into the crater.

d. Unstable tuff remaining on the outer flank of the ring sides toward the southeast along a more competent detachment horizon. 
Return to Bend, via Oregon Highway 31. For more information on the region, see the enclosed references.

\section{REFERENCES}

Fisher, R. V., 1977, Erosion by volcanic base-surge density currents: U-shaped channels. Geol. Soc. Amer. Bull. 88, 1287-1297.

Hampton, E. R., 1964, Geologic factors that control the occurrence and availability of ground water in the Fort Rock basin, Lake County, Oregon. U.S. Geol. Surv. Prof . Paper 383B, B1-B29.

Heiken, G. H., 1971, Tuff rings: examples from the Fort Rock - Christmas Lake Valley basin, south-central Oregon. Jour. Geophys. Res., 76, 5615-5626.

Jakobsson, S. P., 1978, Environmental factors controlling the palagonitization of the Surtsey tephra, Iceland. Bull. Geol. Soc. Denmark, 27, 91-105.

Lorenz, V., 1970, Some aspects of the eruption mechanism of the Big Hole maar, central Oregon. Geol. Soc. Amer. Bull. 81B, 1823-1830.

Lorenz, V., 1971, An investigation of volcanic depressions. Part IV. Origin of Hole-in-the-ground, a maar in central Oregon. NASA Progress Report, NGR-38-003-012, $113 \mathrm{p}$.

Lusacco, U. and Parea, G. C., 1969, Saggio di un atlante di strutture sedimentarie e post-sedimentarie osservate nelle piroclastiti del Lazio. Atti Soc. Nat. e Matem. di Modena, $94,30 \mathrm{p}$.

MacLeod, N. S., Walker, G. W., and McKee, E. H., 1976, Geothermal significance of eastward increase in age of upper Cenozoic rhyolite domes in southeastern Oregon. in Proc., Second United Nations Symposium on the Development and Use of Geothermal Resources, 465-474.

Mattson, P. A. and Alvarez, W., 1973, Base surge deposits in Pleistocene volcanic ash near Rome. Bull. Volcanol., 37, 553-572.

Peterson, N. V. and Groh, E. A., 1961, Hole-in-the-ground, central Oregon. Meteorite Crater or volcanic explosion? The Ore Bin, 25, 73-88.

Peterson, N. V. and Groh, E. A., 1963, Maars of south-central Oregon. The Ore Bin, 25, 73-89. 
ROADLOG FOR FIELD TRIP TO MEDICINE LAKE HIGHLAND

Julie M. Donnelly-Nolan, U.S. Geological Survey, MS 18, 345 Middlefield Rd., Menlo Park, CA 94025

Eugene V. Ciancanelli, Cascadia Exploration Corporation, 3358 Apostol Rd. Escondido, CA 92025

John C. Eichelberger, Geological Research G-6, Los Alamos Scientific Laboratory, Los Alamos, NM 87545

Jon H. Fink, Geology Department, Stanford University, Stanford, CA 94305

Grant Heiken, Geological Research G-6, Los Alamos Scientific Laboratory, Los Alamos, NM 87545*

MILES (interval mileage in parentheses)

0 Leave Cimarron Motel, 3060 So. 6th St., Klamath Falls, and head east

3.1 At "Y" in road, keep right to avoid going toward Winnemucca. Continue south on Oregon Highway 39.

$(14.0)$

17.1 Highway turns east at Merrill. Pass through town and continue east to

(2.0)

19.1

$(1.9)$

21.0 Jog left to State Line Liquors, then right, and continue south toward Fish and

33.8

$(3.3)$

37.1 STOP 1. Captain Jack's Stronghold.

Geologically, this stop illustrates flow-end features in a high-alumina basalt flow. The stronghold is one of the major features at Lava Beds National Monument, and Aaron Waters has contributed his geo-historical study of the Stronghold to the published guidebook. One of the Park Rangers, Patti Easterla (whose grandfather was born in the Stronghold during the Modoc War) has agreed to guide us through this natural fortress and explain how so few Indians were able to hold off so many U.S. soldiers for so long.

The unusual topography here, which was so critical to the Modoc's defense, is explained by Waters (this volume).

Drive west from Captain Jack's Stronghold, facing directly toward the north-south fault scarp known as Gillem's Bluff. Pre-Highland lavas are exposed in the scarp, which is one of several stepping up to the west. As the road turns south, note the Big Horn Sheep Enclosure where some 35-40 sheep currently live. The Park Service is attempting to reintroduce the sheep which were once native but were killed off around 1900 .

* Authors are listed alphabetically except first author. See Acknowledgements for further credits. 


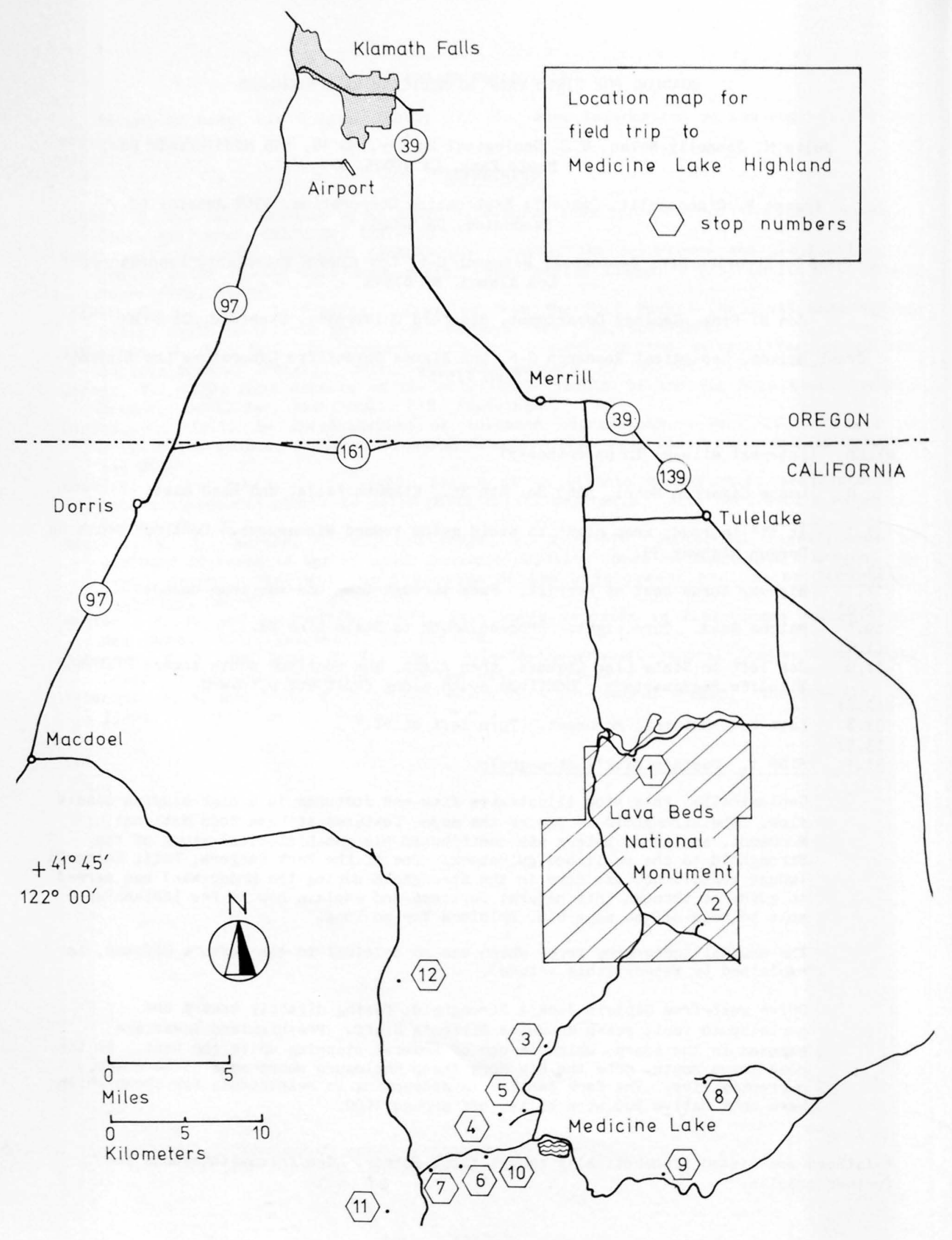


(12.9)

50.0

(1.7)

51.7

(0.2)

51.9

(0.3)

52.2

(2.8)

55.0

(4.6)

57.6

(6.3)

63.9

(0.1)

64.0

(0.1)

64.1

(1.8)

65.9

As you leave the fault scarp and head southeast, cross the Devil's Homestead flow which is very young in appearance. It apparently vented at Fleener Chimneys, spatter cones sitting astride the southward continuation of the Gillem's Bluff fault scarp.

Visitor Center

Turn left onto Valentine Cave Road

STOP 2. Valentine Cave.

This is one of nearly 300 lava tube caves in Lava Beds National Monument. Many of the more important and accessible caves have been mapped in detail by Aaron Waters and his field assistants, at the request of the National Park Service. Waters has also written descriptions to accompany the maps, one of which describes Valentine Cave (Waters, 1976).

"Valentine is an interesting, clean and varied cave. Here one can see a lava-tube system which is almost undamaged by post-lava collapse. The cave shows most of the features to be found in lava tubes: among them pahoehoe floors, lava pools, and lava cascades; well-developed lavacicles and dripstone on ceilings and walls; extraordinarily interesting lava benches, one of which marks a high-level stand of viscous lava that attempted to crust outward from the walls; and still another kind of bench made by the penetration and "bulldozing" away of collapse blocks and rubble as molten lava under hydraulic pressure forced its way through the tube. Large pillars around which the lava stream divided and reunited are present in the upper part of the cave. The central part of the cave shows interesting lava falls and cascades through which the lava stream was transferred from a higher level to a lower level. Downstream from this area of breakdowns, the Valentine tube subdivides into distributaries which are gradually phased out downstream by filling with lava."

Return to main road and turn right.

Drive past Visitor Center again and turn left onto dirt road to Medicine Lake.

Mammoth Crater (optional stop). Pit crater at summit of broad, low, basaltic shield. Source of many of the lavas in the Monument, probably including the flow that made the Stronghold (Waters, this volume.)

Continue south, first on paved and then on dirt road.

Turn sharp right and drive one-tenth of a mile along west side of spatter cones.

Park and walk north along spatter cones, then up onto flow for

STOP 3. Tree Molds

There are numerous tree molds in the area immediately north of the last of the several spatter cones that are aligned approximately north-south. The lava was apparently very fluid when it first emerged, flowing around the trees in its path. Many of the molds are large enough to climb down into. Most are 10-15 feet deep; a few had snow at the bottom all summer. About 200 feet north of the last spatter cone, the flow has a rougher surface and there appear to be no more molds.

Return to main road and turn right; continue south.

Turn right on good dirt road. 
Park and hike northwest about 200 feet to narrow dirt track. Turn left and walk about half a mile into an area of recent cracks. The largest one is 30 to 40 feet deep and has snow at the bottom. The exposed sequence is pumice over scoria, both overlying platy andesite that is well-displayed in the ragged edges of the cracks. Most cracks trend north to northeast here, with the west side down where offset can be determined. This is the same offset displayed at the next part of Stop 4.

Faulted cinder cone.

Return to dirt road track and walk northwest to pumice-covered cinder cone. Climb up on cone and stand on east side of fault scarp. The scarp is red and bare of pumice, thus fault movement followed deposition of the pumice. The fault trends north-northeast and at each end is covered by a very young rhyolitic flow.

There is an excellent view to the northwest from this spot. Eat lunch and then proceed north along the fault to Crater Glass Flow. Climb up on the flow and examine the spines on the surface. Note the scarcity of pumice on top of the flow despite the abuncance of pumice surrounding it.

Return to cars and proceed northeast to junction with main road.

Park for STOP 5. Glacial Striations.

Andesite is polished and grooved in a northwesterly direction. See Anderson (1941) for a description of the glaciation of the Highland.

Return to cars and proceed northeast to junction with main road.

67.9 Turn right and drive south over rim of caldera as described by Anderson (1941).

$(0.3)$ right at next intersection with a good road.

\section{Turnoff to Little Mt. Hoffman. Keep right.}

At Little Glass Mountain, turn left and follow east edge of flow.

STOP 6. Park for first Little Glass Mountain stop. See accompaning article by J. H. Fink for description.

This stop offers an opportunity to observe the different units which make up the flow stratigraphy. First we note the layer of tephra which covers the ground surrounding the flow. Isopach maps indicate that the source of this tephra is under Little Glass Mountain (Heiken, 1978).

Return to junction and turn left, driving around north side of Little Glass Mountain.

STOP 7. Park for second Little Glass Mountain stop. See accompaning article by J. H. Fink for description.

Turn around and return to Medicine Lake.

Medicine Campground. 
Leave Medicine Campground. Proceed east to Amnica Sink turnoff.

83.7

$(0.8)$

84.5

(1.)

86.6

(0.8)

87.4

(1.5)

88.9

(4.2)

93.1

(9.7)

102.8

$(0.6)$

103.4

(0.8)

104.2

(2.4)

106.6

$(0.4)$

107.0

$(0.2)$

107.2

Turn left.

View of Annica Sink. Take either fork. Anderson (1941) felt that Annica

Sink had been connected with Medicine Lake prior to extrusion of the Medicine Lake dacite flow. Keep on the main road and head east.

Road junction. Turn left.

Note Hoffman dacite flow on left.

Road junction. Turn left toward Glass Mountain.

Pause for view: dome of Glass Mountain to northeast, Hoffman flow (dacite) in foreground, rhyolite dome of Mt. Hoffman to northwest (highest point on the Highland), and directly north is a bare area on the forested ridge in the distance. At the bare area (the "Hot Spot") steam is emitted and temperatures of $890 \mathrm{C}$ have been measured within a half meter of the surface. Continue around south edge of Glass Mountain. Red Shale Butte and Lyons Peak, on the right, consist mostly of basalt and andesite.

Road junction. Turn left.

Sharp left turn onto dint road (sign points to Lava Beds N.M., 10 mi.).

Road junction. Keep left.

Turn left onto pumice-covered road.

Road junction. Keep right.

Turn sharp left onto narrow road running parallel to flow front.

STOP 8. Glass Mountain

Park and walk up bulldozed road onto flow. This location was chosen specifically to show the mixing of magmas involved in the genesis of the Glass Mountain dacite-rhyolite flow (Anderson, 1933; Eichelberger, 1974, 1975).

The north quarry site affords an opportunity to see the extremes in lava types produced during a single eruption of the Glass Mountain volcano. Thirteen vents along a northwest-southeast trending fissure were active during this eruption, which occurred within the last thousand years. Nine northwestern vents and the southeastern-most vent produced domes, while lavas of the intervening three vents coalesced to form the Glass Mountain flow, $1 \mathrm{~km}^{3}$ in volume. The flow consists af three dacitic eastern lobes which grade westward to rhyolite and are overlain by rhyolite lobes.

We are now at the point where the largest of the rhyolite lobes stopped as it overran the largest of the earlier dacite lobes. The dacite lobe flowed a total of $6 \mathrm{~km}$ from the middle flow vent; our present location is $31 / 2 \mathrm{~km}$ from that vent. The northern flow vent probably also fed this lobe, and the southern flow vent may have contributed lava as well. The rhyolite lobe came entirely from the northern flow vent, $3 \mathrm{~km}$ distant. However, there was no break in the eruption between the two lobes, since the lobes merge in a continuous surface west of the vents. Nor is there any discontinuity in lithology, since the dacite lobe grades upstream to rhyolite at the middle and south vents. Variation in lithology within lobes occurs over a shorter 
distance normal to stream flow, reflecting the strong velocity gradient in that direction during emplacement. Hence "younger," and therefore more rhyolitic, lava occurs in the inner portion of each lobe.

Contrast between the older and younger lobes is apparent in flow morphology as well as lithology. The rhyolite lobe is 2-3 times thicker than the dacite lobe on the same slope. The dacite varies from dense, massive lava with some flow banding to vesicular, scoriaceous, and brecciated materials, particularly abundant on the flow surface. The dacite always contains abundant basaltic xenoliths, and a large portion of the phenocrysts within the dacite were derived from disaggregation of these xenoliths. The rhyolite varies from dense obsidian to very light pumice which is confined to the surface. Obsidian has been forced upward through the surface pumice in pressure ridges. Interiors of both the dacite and rhyolite lobes are massive lava.

Samples of the basaltic xenoliths have a density of $2.15 \pm 0.04 \mathrm{~g} / \mathrm{cm} 3$, independent of the vesicularity or composition of the host lava. The mass density of the xenoliths (i.e. density without vesicles) is $2.79 \pm 0.01$ $\mathrm{g} / \mathrm{cm}^{3}$. Densities of non-vesicular host lavas are as follows: obsidian near middle vent--2.38 $\pm 0.01 \mathrm{~g} / \mathrm{cm}^{3}$, dacite at this stop--2.49 $\mathrm{g} / \mathrm{cm}^{3}$, dacite at distal end of this $10 \mathrm{be}--2.55 \mathrm{~g} / \mathrm{cm}^{3}$.

Development of this compositionally zoned flow can be viewed as a consequence of "bubbling" of basaltic magma through a rhyolitic magma chamber. Bulk composition and phase assemblage of the dacite are attributable to addition of basaltic material to rhyolitic magma. The rounded shape of the xenoliths and distinctive "quench" texture indicate that basalt was introduced into the chamber as a liquid, was chilled against rhyolitic magma, and consequently underwent rapid crystallization. Vesiculation accompanying crystallization produced a layer of low-density foam at the base of the rhyolitic magma body. This foam was removed by flotation as it formed and became concentrated at the roof of the chamber. The volume increase due to inflation of the foam triggered the eruption which

first tapped the foam-rich hybrid dacite at the top of the chamber.

Eruptions of similar lavas prior to the Glass Mountain event suggest that the chamber is a large-volume, long-lived feature beneath the Highland. Known densities of the materials, evidence that flotation occurred, and reasonable estimates of water content of basaltic magma constrain the depth of this chamber to within about $10 \mathrm{~km}$ of the surface.

The road onto the flow provides easy access to the surface of the rhyolite lobe. The climb takes 15-20 minutes and provides views of the summit dome which was extruded from the north flow vent, the distal end of the dacite lobe, and many other interesting features of Glass Mountain and its environs.

$(1.4)$

108.6

$(3.9)$

112.5

$(9.8)$

122.3

$(0.9)$

123.2
Drive east on narrow road back to main road. Turn right.

Junction with paved road. Turn sharp right and return toward Medicine Lake.

Turnoff to Glass Mountain. Keep left.

STOP 9 (optional).

At second turnoff to Glass Mountain, park at intersection and hike north in to explosion crater. This is one in a northeast-trending series of explosion craters which extend for about three miles. These craters expose the local stratigraphy which here is andesite over porphyritic Lake Basalt.

Continue on main gravelled road keeping first right, then left, at

intersections with other good roads, to four-way intersection. 
(3.4)

126.6

(6.1)

132.7

(0.7)

133.4

(0.6)

134.0

(1.4)

135.4

(2.1)

137.5

(1.1)

138.6

(0.8)

139.4

(0.9)

140.3

(2.1)

142.4

(0.8)

153.2

(0.9)

154.1
Turn right toward Medicine Lake. Continue past Medicine Lake campgrounds and Ranger Station west toward Little Glass Mountain.

Little Mt. Hoffman turnoff. Turn left.

STOP 10. Little Mt. Hoffman

Lunch and panoramic view (weather permitting) of Mt. Shasta, Lassen Peak, and Mt. McLaughlin, with Little Glass Mountain directly below us.

Bottom of Little Mt. Hoffman. Turn left at junction.

At Little Glass Mountain, keep right.

Turn left at main (Harris Spring) road.

Road to Lost Spring and Tennant. Turn right.

At junction with road to Tennant, continue straight ahead toward Lost Spring.

STOP 11. Andesite Tuff

This is nearly the southernmost mapped exposure of this ash-flow tuff. Here it is nonwelded to partially welded and you can see both the unoxidized buff-colored matrix having dark gray pumices, and the reddish to reddish-brown matrix color which is more typical of this widespread and distinctive unit. It extends at least 200 feet uphill to the west and is nonwelded to partially welded throughout. According to mapping by Hughes (1974), the tuff is exposed a mile and a half to the north at at elevation of 6400 feet, its highest known occurrence. It is also mapped by Weaver (1975) four miles to the southwest. Hart (1975) mapped large areas of it in the northeastern quarter of the Bray $15^{\prime}$ quadrangle, just west of the Medicine Lake quadrangle. Hughes, Weaver, and Hart were students of S. A. Mertzman at Franklin and Marshall College, and some of their work is summarized in Mertzman (1977).

The thickest apparent exposure of the tuff is right here, but its poorly-welded character suggests that the tuff may simply be coating the surface of the hillside to the west. To the north, the tuff is exposed on the south side of Mt. Dome, almost 20 miles from here. To the northeast, we have mapped it east of the Callahan flow at about 5800 feet in elevation. In the areas to the north and east, it is a very thin unit, always less than 20 feet thick and typically 2-5 feet thick. The source of the tuff is unknown but may be buried under younger lavas to the northwest of Medicine Lake. If the tuff's average thickness is taken to be 20 feet and its areal extent to be 250 square miles, its total erupted volume is one cubic mile. Although its volume is minor, it is very important as a stratigraphic marker.

- Drive a tenth of a mile further down the road, turn around, and return to Harris Spring road. Turn left. Proceed north on good road past cattle guard.

Turn right on next good dirt road.

Follow road east then south just past junction. Park. 
Porphyritic olivine basalt overlies glassy andesite and underlies andesite tuff. Walk up on top of tuff to get view south toward the Highland. Directly to the south near Dock Well, about 5 miles from here the tuff overlies these same two units as well as two other andesites and two silicic domes. Anderson (1941) thought that the domes had intruded into a

two-hundred-foot thickness of andesite tuff, but detailed mapping shows that the tuff flowed around the domes, lapping up onto the eastern one. The tuff is actually very thin, and it appears unstratified because it has flowed down a steep slope and because most blocks are viewed from the top. Samples collected near Dock Well yield a normal magnetic polarity.

Further to the east, but west of the Callahan flow, the tuff is exposed in patches as high as 5600 feet. It overlies an olivine andesite, two basalts, and an older rhyolite flow. East of the Callahan flow it overlies a glassy porphyritic dacite and an andesite, as well as an older sequence of aphyric rhyolite and dacite on top of porphyritic spherulitic rhyolite. The pre-tuff sequence in each case is complex, with all rock types from basalt through rhyolite represented. The post-tuff sequence consists mostly of silicic andesites piled up around Medicine Lake and young basalts on the flanks of the volcano. The youngest eruptions are bimodal, with basalts lower and rhyolites higher on the volcano.

$(0.9)$

155.0

Turn around and return to paved road. Turn right. About $41 / 2$ miles further north, there is a good paved road to the right. Keep left and proceed northwest into Red Rock Valley, then west and northwest to Macdoel and Highway 97. Turn right and go north through Dorris toward Klamath Falls. For those returning to the Klamath Falls airport, turn right at Joe Wright Road (sign points to Kingsley Field which is the Klamath Falls airport).

\section{Acknowledgements}

Donnelly-Nolan was principally responsible for the road log, but Ciancanelli, Fink, and Heiken provided valuable assistance in choosing field trip stops. Eichelberger wrote the description of Glass Mountain (Stop 8), Ciancanelli measured the temperature at the Hot Spot. L. Hose provided valuable assistance with field trip logistics and also discovered and mapped the exposures of andesite tuff east of the Callahan flow.

We wish to thank P. Easterla of the staff at Lava Beds National Monument for guiding us through Captain Jack's Stronghold and A. C. Waters for contributing the unpublished description of Valentine Cave. We also thank the U.S. Forest Service and the U. S. Park Service for their cooperation and assistance.

\section{References}

Anderson, C. A., 1933, Volcanic history of Glass Mountain, northern California: American Journal of Science, vol. 26, p. 485-506.

1941, Volcanoes of the Medicine Lake Highland, California: University of California Publications, Bulletin of the Department of Geological Sciences, vol. 25, no. 7 , p. $347-422$.

Eichelberger, J. C., 1974, Magma contamination within the volcanic pile: origin of andesite and dacite: Geology, vol. 2, p. 29-33.

1975, Origin of andesite and dacite: evidence of mixing at Glass Mountain in California and at other circum-Pacific volcanoes: Geological Society of America Bulletin, vol. 86, p. 1381-1391.

Hart, W. K., 1975, Geology of the northern one-half of the Bray Quadrangle: map to 
accompany unpublished B.A. thesis, Franklin and Marshall College, scale 1:62,500.

Heiken, G., 1978, Plinian-type eruptions in the Medicine Lake Highland, California, and the nature of the underlying magma: Journal of Volcanology and Geothermal Research, vol. 4, p. 375-402.

Hughes, J., 1974, Geology of the western Medicine Lake Highlands and Garner Mt. Area, map to accompany unpublished B.A. thesis, Franklin and Marshall College, scale $1: 62,500$.

Mertzman, S. A., Jr., 1977, The petrology and geochemistry of the Medicine Lake

Volcano, California: Contributions to Mineralogy and Petrology, v. 62, p. $221-247$.

Waters, A. C., in press, Captain Jack's Stronghold: this volume. 1976, Valentine Cave: National Park Service unpublished document.

Weaver, S., 1975, Geology of the southeast Bray quadrangle, California: map to accompany unpublished B.A. thesis, Franklin and Marshall College, scale 1:62,500. 


\section{Introduction}

"..... reached by a side road, the visitor comes to Captain Jack's stronghold, an area of natural rock trenches and rock shelters in the lava flows, where a tiny band of Indians held hundreds of troops at bay for almost 5 months..... The record tells the tale of a motley army of badly trained soldiers, led by inept officers on a battlefield of the Indian's choosing about which the army intelligence had absolutely no information. Given such conditions, tragedy was inevitable for settlers on the north shore of Tule Lake, and for Jack's and Hooker Jim's bands of Modocs." (Keith A. Murray, in preface to Erwin R. Thompson, 1971, Modoc War: Argus Books, Sacramento, Calif., 188 p. plus appendices).

Last of the California Indian uprisings, the Modoc War (November 29, 1872 to June 4, 1873) has been chronicled by many newspaper writers, historians, social scientists, and others. The written record, however, is blurred and contradictory as to the causes, motives, heroism, and savagery of principal participants on both sides. Parts of the record have been greatly fictionalized and romanticized, and some even falsified as Jeff $C$. Riddle scornfully notes:

"I have read Capt. William T. Drannan's book, 'Thirty Years on the Plains,' where he wrote about the Modoc warriors. According to what he says, he captured and killed more Modoc warriors than Capt. Jack really had when he commenced fighting. Jack had only fifty-two warriors in all. I knew every one of them. ("Jeff C. Riddle, 1914 (reprinted 1974), The Indian History of the Modoc War, Urion Press, Eugene, Oregon, 295 p.)

Our report and accompanying map makes no attempt "to set the record straight" with regard to what has been reported about the historic and sociological roots of the Modoc War. Instead we investigate the question repeatedly asked by almost every writer: How was it possible that 53 Modoc men, aided (or encumbered ?) by twice as many women and children, withstood a siege through the dead of winter, routed 300 U.S. troops engaged in the first major assault, withdrew undetected after repulsing a second assault of 650 troops supported by mortars and howitzers, and then only a few days later staged a successful ambush and inflicted 25 fatalities upon a patrol composed of 59 enlisted men and 6 officers?

One part of the answer to this question is that the Indians chose a superb, but by no means unique, natural fortress in which to make their stand. This fortress, however, is only one part of the total equation. The vital point is that the Modocs knew thoroughly and in detail the nature of the terrain south of the shore line of Tule Lake; the army was totally ignorant of this landscape's military advantages. Writers about the Modoc War clearly have not understood the real nature of the terrain in which the Indians holed up any more than did the U.S. troops and their officers. One historian writes vaguely about the Modocs "disappearing into the Schonchin flow" as if this barren patch of recent aa lava had some mythical power to swallow up the Indians and hide them from pursuing Army patrols. In fact this almost treeless expanse of small and loose blocks of lava would be the worst possible place for the Indians to try to hide; and the Modocs avoided the Schonchin flow completely. Some writers have assumed that the Stronghold is "within the Schonchin flow, " but the distal end of the Schonchin flow is 3.8 kilometers $(2.4$ miles) south of the stronghold, and the source of the flow is at the east base of Schonchin Butte, another 6.4 kilometers (4 miles) further south. The Schonchin flow played no part in the Modoc war, except it seems possible that a few members of Captain Jack's band may have staged the Thomas-Wright ambush out of fear of being trapped by this army patrol against the inhospitable west edge of the Schonchin flow.

We will first describe the terrain in and near the Stronghold, as seen through the eyes of a geologist. Then we return to the Modoc War and discuss, in terms of terrain, the consequences of the first and second assaults by the Army upon the Stronghold, followed by an analysis of how the Modocs were able to withdraw from the Stronghold undetected, and a few days later stage the disastrous Thomas-Wright ambush.

\section{The Terrain}

Today the country in and adjacent to Captain Jack's Stronghold consists of four kinds of topographic surfaces (see map).

1. The Tulelake plain, which in 1872-1873 lay beneath the waters of Tule Lake. Since 1906 over $3 / 4$ of the area of this large but shallow lake has been reclaimed for farmland.

2. Lowlands, of low relief, underlain by lobes and tongues of solidified lava, border the shoreline both to the east and west of the Stronghold. The lowlands are rough surfaced in places, but the variation in height is 2 meters or less. The lava tongues grade at the shoreline into pillow lavas interspersed with sandy beaches of hyaloclastic debris (black glass sand and pillow-like ellipsoids of basaltic lava, which formed where the molten lava tongues were quenched and granulated by entry into the waters of former Tule Lake). 

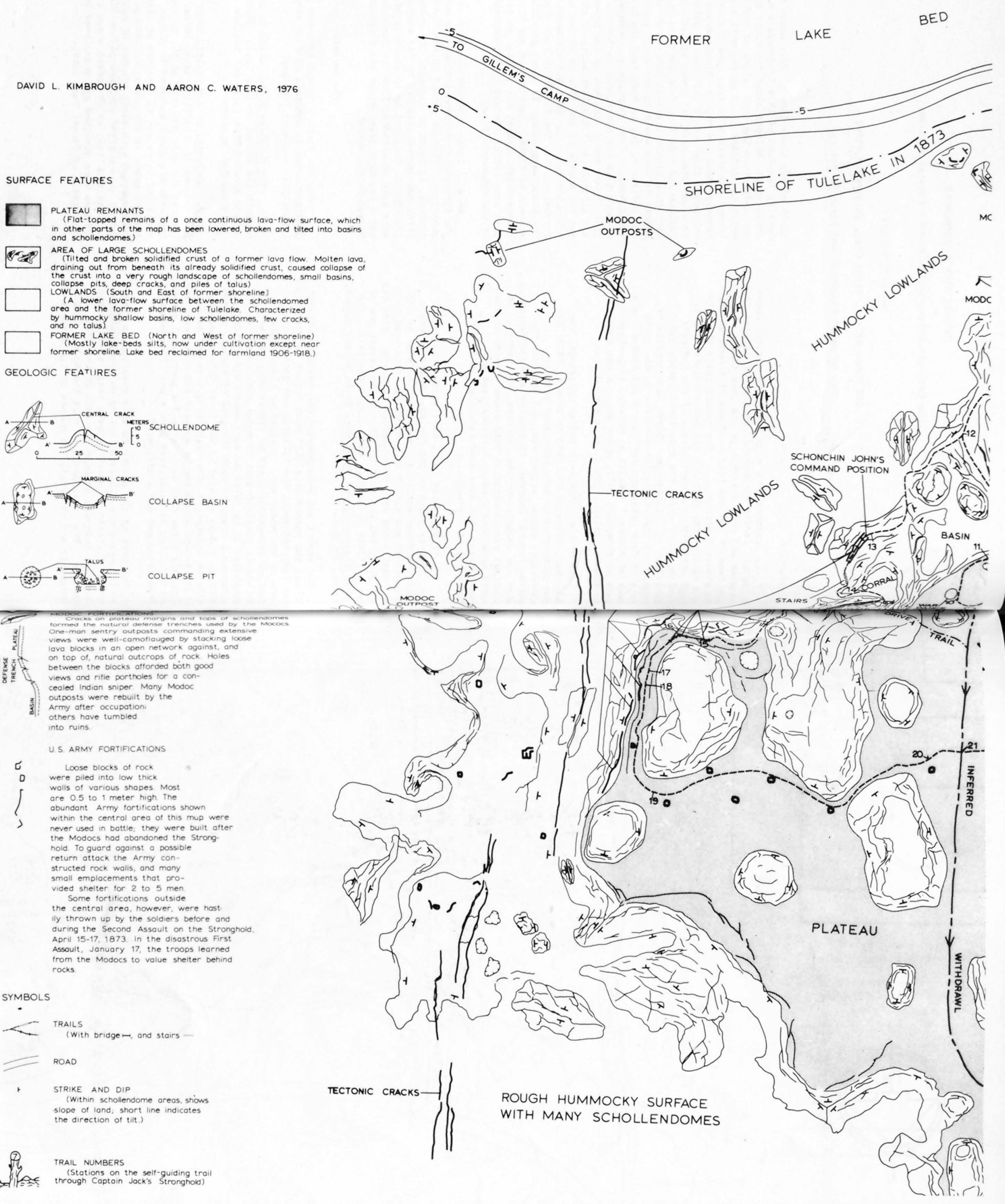

A

COLLAPSE BASIN

(8)

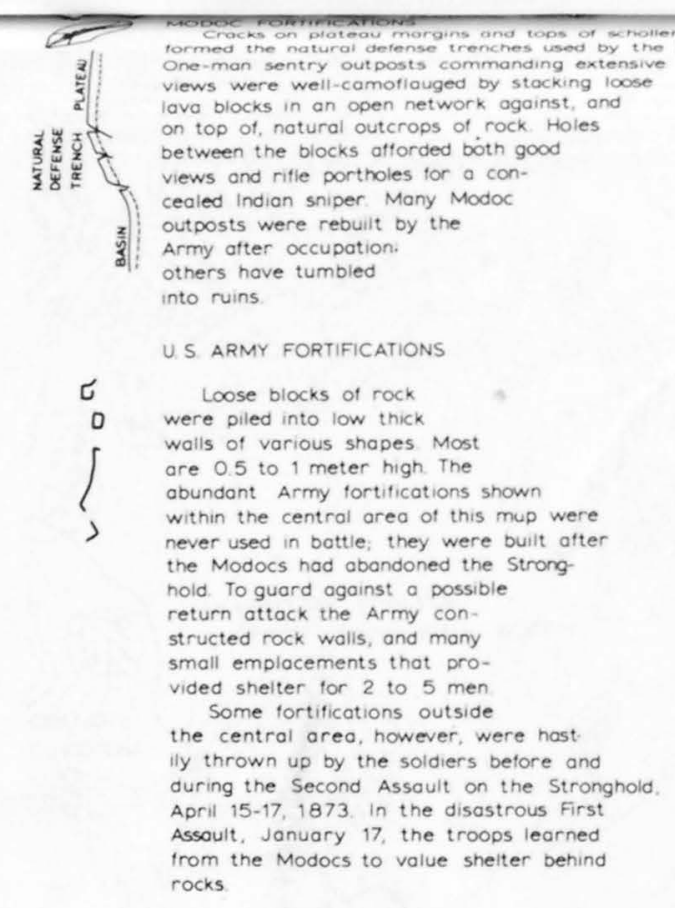

SYMBOLS

-... traills

- (With bridge - and stairs -

STRIKE AND DIP

(Within schollendome areas, shious slope of land; short line indicates

7 TRAIL NUMBERS

TRAIL NUMBERS
(Stations on the selt-guiding trail
through Coptoin Jack's Stronghoti 


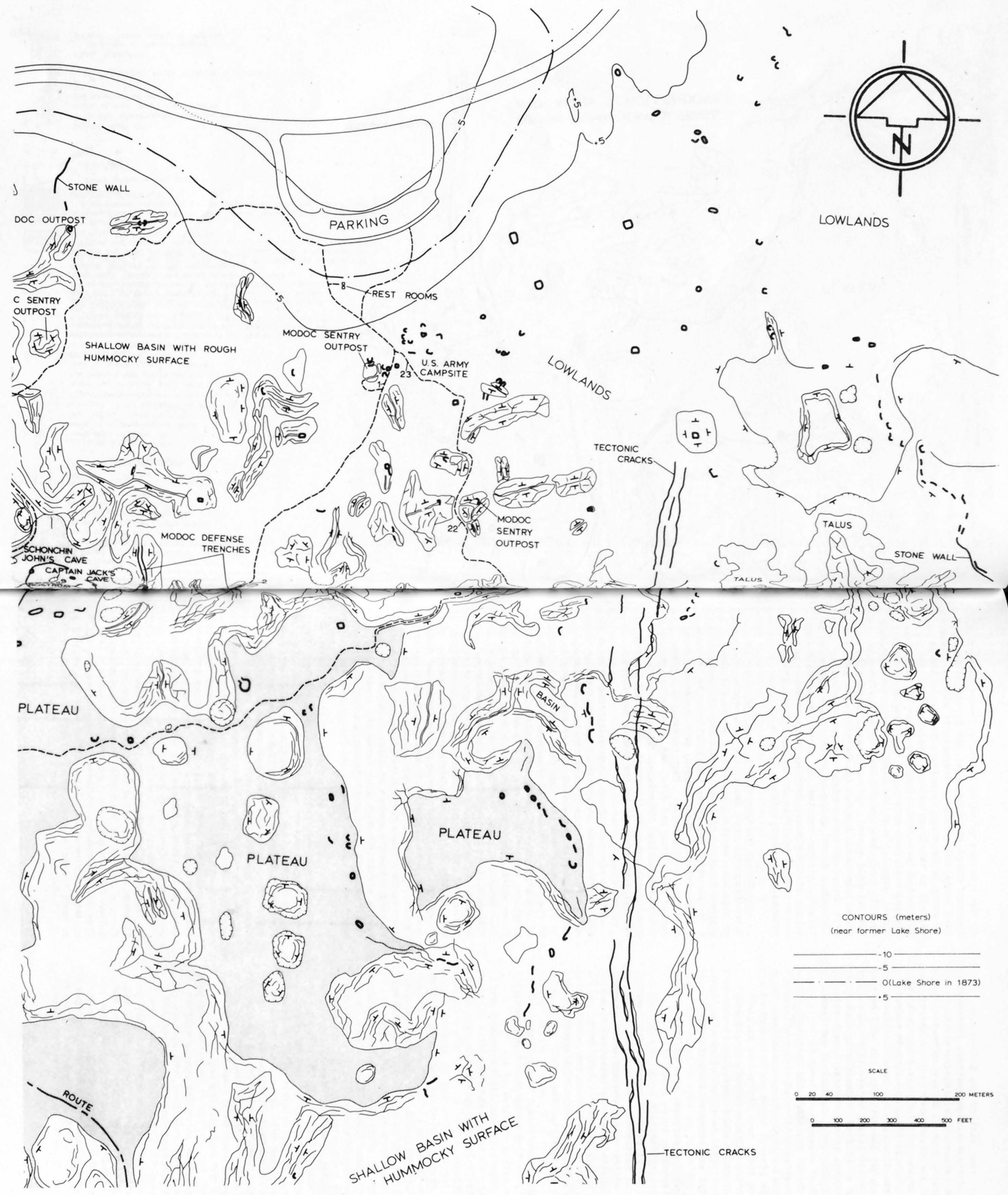


3. The Plateau, that part of the Stronghold where the Modocs had their living quarters (see map) is the northernmost remnant of a plateau, whose surface $r$ ises gradually from 10 meters above the former shoreline at the Stronghold to 30-40 meters a few miles farther south. This plateau (shown with a zip pattern on the map) is the surface of an older and much thicker lava flow than the ones that form tongues and lobes across the lowlands. As will be described in more detail later, before this thick flow had completely solidified, renewed eruptions swelled its still molten interior until lava broke out from the flow front, and also drained out from beneath its solidified crust in a plexus of underground lava tubes. Therefore the plateau surface in the Stronghold is dimpled with small sag basins and by vertical-walled collapse pits (see map). Moreover, the plateau edges which were close to the original flow front have "turn-down margins" produced as the plateau surface sagged outward and was riven with deep cracks and fissures as it was rafted forward and let down to a lower elevation while molten material was escaping from beneath it,

4. Schollendomes. A marginal area of large schollendomes is present on three sides of the plateau remnant in the Stronghold area, and it continues to border other plateau remnants for many miles to the east and southwest. These schollendomes are detached parts of the former plateau crust which have broken into elongate domes characterized by a deep central cleft along their top. Many deep fissures and minor cracks branch from the central cleft. (For description and sketch of a schollendome see the Explanation accompanying the map).

We now describe in more detail the geologic nature and origin of each of these four topographic units as they occur within the area of the accompanying map. This will give the background and perspective necessary to understand how the topography was effectively used by the Modoc defenders of the stronghold.

\section{Tulelake plain, Contrasted with the Tule Lake of 1872}

In 1872 the area north of Captain Jack's Stronghold looked very different than it does today. Instead of the grain fields laced with irrigation and drainage ditches, the waters of Tule Lake lapped against a steep slope of crazily tilted lava blocks that formed a schollendome field between the shoreline and a flat-topped plateau 12 to 20 meters above the lake. The change from lake to farms was brought about by diversion of Lost River to irrigate arid lands farther west. Over a period of about 12 years (1906-1918) the lake shrank to less than $1 / 4$ of its former area, and the hyaloclastic silts and sands on the lake bed, fortified with organic matter from the tule swamps that flourish in shallow water, became rich farm land. The position of the original shoreline in 1873, and the shape of the present 1 and surface immediately adjacent to it, are shown by 5-meter contours on the accompanying map.

Only over a stretch of about 500 meters (1/3 mile) did the shoreline of Tule Lake come against the belt of large schollendomes that rim the plateau remnant of the Stronghold. Both east and west the shoreline is against lava lowlands that rise only 0 to 3 meters above the level of the former lake. The site of a non-permanent Indian village that occupied a rocky ledge just above lake level on the eastern lowland one kilometer $(0.6 \mathrm{mile})$ northeast of the center of the stronghold (see map) can be identified by the numerous grinding holes for seeds abraded into the surface of the lava rock, and by the litter of bird bones and shells of fresh-water clams. Today a 10 -meter bluff drops from the site of the Indian village to the former lake floor, which is now cultivated farm land. Here the shore of Tule Lake dropped into deep water, but other parts of the shore, especially at the head of bays, were bordered by wide sandy beaches and bayhead bars formed of hyaloclastic gravel, silt and sand. Sand and silt blown from these beaches by the wind also smoothed over the rough lava surface of the adjacent lowlands. Travel along or close to the shoreline was relatively easy, but the bay where the schollendomed margin of the plateau reached the lake was a place where passage could be denied by a small group of determined outpost snipers.

The Broken Surface of the Lava Plateau. - In describing with more detail the area above the level of Tule Lake we start with the plateau and then proceed to areas of lower elevation. This is the order in which the three topographic units (plateau surface, schollendomed margin, and lowlands), were developed geologically. Each represents a phase during the climax and dying out of a major episode of volcanic activity. Tracing them in order of development makes it easier to understand how the natural fortress used by the Modocs was formed.

The surface of the plateau (zippitone area on the map) is the top of an unusually thick lava flow which spread into this area from the north. Numerous cracks along the margin of the plateau penetrate 10 to 12 meters below its top; this depth is perhaps $1 / 3$ of the total thickness of the lava flow at the time of its greatest inflation during the climax of the eruption. The flow is one of a great number of lava flows which spread north and east from vents in and near Mammoth Crater, located 15 kilometers $(9.4$ miles) airline to the south. The molten lava, however, did not travel all this distance on the surface of the ground. Instead it was transmitted most of the way through underground lava tubes. (For an analysis of various parts of the lava-tube systems see the maps and reports on display at the visitor Center in Lava Beds National Monument). Small distributary tubes fanning out from one major branch of this intricate system of large lava tubes became active within the flow that forms the plateau at Captain Jack's Stronghold during the last stages of eruption, as we show later.

The distribution of remnants of the plateau surface indicates that this thick flow reached its farthest north extent within the area of Captain Jack's Stronghold. From here the irregularly lobate flow front trended about South $65^{\circ}$ East to and beyond Fern Cave; and in the opposite direction it runs approximately South $30^{\circ}$ West for about 3 kilometers. At most points, however, the exact position of the flow front can be inferred only within a width of about 500 meters, because in almost all places the flow's margin was broken up and partly inundated by late movements of molten lava within the interior of the flow after its front and crust had partly solidified.

After the flow front stopped moving and a 1 - to 15-meter thick crust had congealed on top of the flow, a resurgence of volcanism sent large volumes of molten lava through the long system of tubes. Lava from distal branches of these tubes entered the still molten interior of the flow, lifting it and putting so much hydraulic stress against the flow front that 
molten lava broke through in numerous places. During this maximum phase of eruptive activity the still nolten lava beneath the plateau crust began to creep toward these new breaches, setting up skeins of flow toward the points of lowest stress. During the toward stages large parts of the flow front and parts of the crust of the flow began to break up under these stresses and were rafted slowly forward on the back of the moving currents below. At the base of the flow front small lobes and tongues of molten lava escaped to the surface and flowed on to the north. After eruptive activity at the distant vents had ceased the molten interior of the flow and the lava filling the underground tubes continued to drain out, leaving many parts of the plateau crust unsupported. such parts sagged downward, replacing the space left by the departing lava from the interior. Large masses of the solidified flow front, and finger-like tongues of the crust extending hundreds of meters upstream from the flow front, sagged down and were dragged forward as the lava beneath them leaked out. (Note on the map the many small oval collapse basins, and the long finger-like basins with schollendomes which indent the plateau).

Wherever the edge of the plateau "turned down" to replace the escaping lava beneath, deep tensional cracks and fissures formed in the turned down flap. In places parts of these fissured margins were rafted away, forming schollendomes. Nearly all edges of the plateau remnants became an intricate maze of deep fissures which greatly impede travel across this terrain. Where shallow distributary lava tubes drained out, post-lava collapse of the plateau surface into the tubes has left numerous vertical-walled collapse pits and collapse trenches.

Inspect the area of the map at the end of the plateau remnant where the Modocs took up residence. Each of the faint lines represents a crack or fissure too wide to jump over without extreme caution, and for each line on the map there are many more cracks in the ground (omitted from the map). These fissures, especially the big ones at or near the top of the turndown flaps, are the "natural trenches" used by the Modocs. Note that they are nearly continuous along the edge of the plateau on three sides of the Modoc encampment. These plateau-edge fissures, however, were only the last line of defense; the Modocs also used rock clefts on the tops of schollendomes beyond the plateau margin as sentry outposts.

The Schollendomed Margin of the Lava Plateau. The map shows much better than words how this frontal part of the thick flow that formed the plateau was broken up and transformed into a broad marginal area of schollendomes. Schollendomes form when a thick crust of lava congeals over the top of a lava flow, and then is jostled, undermined, and partly carried away by draining out of the still molten lava beneath the crust. Thus the schollendome field at Captain Jack's Stronghold grades upslope into the "turndown" edge of the plateau remnants. Downslope the frontal end of the schollendome field is engulfed by the thin lobes and tongues of lava that escaped to the surface through the ruptured flow front. In areas east and west of the central part of the stronghold this escaping lava aided in the building of the lowlands along the former shore of Tule Lake.

Only the largest of the schollendomes are indicated on our map. The basins between them, and also the "turndown basins" that project like fingers into unbroken parts of the plateau, are cluttered with smaller schollendomes which range down in size to schollen no larger than a small room and only a meter or two in height. Time did not permit us to map the smaller schollen. Moreover, the clutter of lines that would result from plotting all these cracks and fissures would have made the map unreadable. The unbroken expanses of white paper in this part of the map, however, do give a false impression that some of the wider basins in the schollendomed area might be easy to cross. From a distance they also look easily traversible, but actually they are deceptively cruel to a person who tries to cross them in a hurry. We have used the word hummocky in places on the map to indicate that such surfaces are quite irregular, rough with various sized schollendomes, and riven with hundreds of cracks and fissures.

Several high schollendomes outside the plateau remnants provide excellent viewpoints over the shoreline and lowland areas. The Modocs developed them into well-camouflaged sniper positions by piling loose fretworks of rock in or around parts of the central crack.

Lowlands Built of Pillow Lavas and Hyaloclastic Debris. Numerous outcrops where the lowlands meet the former shoreline of Tule Lake show that lava advancing from the south flowed into the lake. Molten lava changes on contact with a water body into pillow lavas and hyaloclastic deposits. These materials filled in the edges of the original Tule Lake, pushing the shoreline northward much like a delta grows at the mouth of a large river. For details of the mechanics of formation of pillow lavas and various kinds of hyaloclastic deposits consult Fuller (1931) and waters and Fisher (1971).

In a quarry developed for road building materials near the site of the former Indian village (see map), we can examine typical examples of pillow lavas with chilled glass rinds, pillow breccias, and granulated slag-like bits of hyaloclastic material (basalt glass) - the three kinds of deposits characteristically formed where molten basalt advances into a water body. In nearby areas molten lava also escaped directly into the lake through lava tubes. Good examples are on the Hovey Point peninsula west of the Stronghold, and there are several additional vent areas and low maar craters to the east between the Stronghold and Hospital Rock. In places molten lava also erupted directly into the lake, building larger underwater volcanoes at The Peninsula, Juniper Butte, and Prisoners Rock localities several miles to the east and south of the Stronghold.

Most of the lowland area probably was built into the lake by the quenching of lavas that are slightly older than the flow that formed the plateau. The late tongues of lava that broke through the schollendomed front of the plateau flow, however, have also assisted in pushing the lake front farther to the north.

The lowland areas are easily traversed. Although the lava surface is minutely rough, and is in places diversified with small schollendomes about a meter high, the area shows none of the deep fissuring, large schollendomes, or broken areas of talus that make the adjacent schollendomed area so difficult to traverse. Moreover, waves and wind have scattered hyaloclastic sands and silts over the surface of many lowland areas, assuring excellent mobility for travel. Soldiers in training on the lowland areas 
near Gillem's Camp, or on the hyaloclastic flats near Hospital Rock, probably had no concept of the kind of terrain they would meet in their assaults on the stronghold.

\section{The Modoc War}

In late November of 1872, two groups of Modoc Indians were encamped at their winter villages, located about $1 / 2$ mile apart on either side of Lost River a few miles upstream from where it entered Tule Lake. On November 29, a surprise confrontation just at dawn with a patrol of soldiers sent to put the Modocs on the Klamath Indian Reservation ended in a shootout, followed by withdrawal of the Indians from each village. One group, led by Captain Jack, and the other by Hooker Jim, each headed for their Stronghold on the opposite (south) shore of Tule Lake. Jack's group, which also included the women and children from both villages, paddled the 13 miles (21 kilometers) across the lake from the mouth of Lost River during the night of November 29-30. The following day they were joined by Hooker Jim's small group of warriors, who had ridden horses along the 35 mile route around the east end of the lake, and had taken revenge for the fatalities incurred in the early dawn confrontation by killing all men at isolated ranches and settlements along the north and east shore of Tule Lake. In the wake of the revenging Modocs, the widowed women and children of the settlers began the long walk across Stukel Mountain to the security of other white settlements. Men of two entirely different cultures, neither of whom fully comprehended the rights or the motives of the other, were now at war.

The Stronghold. Examine the map and note the nature of the natural fortress which was to be the home of the Modocs for the next 5 months. Here the northern tip of the plateau surface overlooks a bay in the south shore of Tule Lake. The part of the plateau closest to the lake is a rounded table approximately 150 meters in diameter - about the size of a modern football stadium. It is bordered on three sides by a field of large schollendomes; to the south a neck about 50 meters wide connects it with a larger remnant of the plateau.

Within the area chosen for the Modoc's living quarters the plateau surface is dimpled by 8 collapse pits, each a vertical-walled hole 2 to 15 meters in diameter and 3 to 8 meters deep. They formed where parts of the plateau's crust caved into small underground lava tubes. Floors of these pits are covered with large angular boulders tumbled from the roof and walls. In places one can burrow around between these boulders, especially beneath the overhanging walls of parts of the pits, and find small chambers each of which would give protection for 1 to 5 individuals against the rain or snow, and also from the strong cold winds that sweep the plateau in winter and spring. Three of these collapse pits are easily visited from the inner trail constructed by the Park Service: Captain Jack's Cave, Schonchin John's Cave, and Family Cave (see map). Nearby a small mound of pahoehoe lava served as a rostrum from which the Modoc leaders could address their people.

Loose rocks picked up from the surface of the plateau were piled into low dry-walls, forming a partial breastworks around parts of the camp. (These fortifications were later rebuilt into much thicker and higher walls by Army soldiers after the Modocs had withdrawn from the Stronghold). The main defense positions used by the Modocs, however, are the deep natural cracks and crevasses along the top of the turndown edges of the plateau, and similar fissures along the tops of high schollendomes which ring thr sides of the Stronghold. The more strategic and important of these Modoc defense trenches are label on the map. Note that they form a sinuous line alo the entire northwest margin of the plateau, and that they curve into a natural U-shaped ambush 1 ine whic bars access to the Stronghold from the nearest poin of the lakeshore. The floors of these natural defense trenches were cleared of loose debris so the the defenders could pass rapidly along them. Short radial routes by which one can walk to various part of the trench system from the central stronghold without encountering difficult crevasses were well known to the Modoc defenders.

Beyond this natural trench system lay scattered Modoc outposts - high isolated overlooks with unimpaired views of the surrounding country. Most such outposts are located in the central cracks of the highest schollendomes, and were further camouflaged by piling loose fretworks of rock throve: which a sniper's rifle could be extended unobserved. No doubt additional Modoc outposts within the area the map have gone unrecognized during our mapping (see the description of Modoc Fortifications on the map).

Contrary to the statements of several writers, these natural defense features of the stronghold a: not unique. Many other table-like remnants of the lava plateau have even more formidable and deeply-crevassed turndown edges. The unique value the stronghold chosen by the Modocs was its proxin: to the shoreline of Tule Lake. A constant supply water, and of some food from wocus root, waterfowl, fish, and fresh-water clams was thus assured. Also its location denied communication for an enemy usit the easily traversible route along the lake shore. Moreover, the Modocs were well aware of an easy escape route to the south over the flat surfaces of scattered remnants of the lava plateau, whereas one unfamiliar with that terrain would flounder painfull and slowly across the heavily fissured and schollendomed country that surrounds these plateau remnants.

Still another unusual topographic feature, a natural cattle corral, was vital in helping the Modocs withstand the winter siege. Just west of the Stronghold encampment is a small and deep collapse basin, bounded on three sides by the steep and heavily crevassed sides of three large schollendomes and on the fourth (east) side by the steep and deep. fissured turndown flap of the plateau. Miraculously these bordering fissures along the edge of the plateau die out about 200 meters to the south. Hert a smooth and easily traversed slope leads down off the surface of the plateau and northward through a narrow "gate" across the end of the southern schollendome into the natural cattle corral. Stray cattle on the southern plains, and others captured Modoc raids, were driven north across the plateau remnants and into this natural corral, where they could be securely penned in by piling a wall of roci and brush across the narrow gate (see map). Thus at adequate supply of beef was available throughout the winter.

Assault of January 17, 1893. Meanwhile the Arn. stung by their lack of success in "rounding up" the Indians and shocked by the murder of 14 settlers by the retreating Modocs after the Lost River 
confrontation, were preparing for a second attempt. Additional troops were called in from other Army Adds, and groups of volunteers from oregon and california (whose enlistment period was only for 30 days) were hastily organized and haphazardly trained. Also recruited were unorganized volunteers and labor support from nearby towns and ranches. By early January 400 "fighting men" were "raring to go." Lieutenant Colonel Frank wheaton set January 17 for the attack on the Modoc's encampment. At that time their natural fortress was unnamed; it soon became known as Captain Jack's stronghold.

Colonel wheaton's strategy was a pincers movement from both west and east. Three hundred men were to be comitted to battle; 100 held in reserve. Captain Green's cavalry (but dismounted as foot troops) along with contingents of Oregon and California volunteers were to bear the brunt of the fighting and attack from the west. Captain Bernard's smaller command was to advance from the east, primarily as a holding force to keep the Modocs from escaping along the lakeshore lowlands. On January 16 the troops moved into position from their training areas. Green's forces marched 13 miles across rough country to a position on the bluff overlooking the southwest corner of Tule Lake (near Gillem's camp on modern maps). On the same day Bernard's force advanced west over the lowlands adjacent to the south shore of Tule Lake, but because of a heavy fog they probed too far, drew the Modoc's fire, and three men were wounded. Bernard's group then withdrew to an area near Hospital Rock (about 3 kilometers east of the stronghold) and camped for the night.

The morning of January 17 was cold, and a heavy fog encompassed the area around the lakeshore. Wheaton and Green's troops, although on the march at dawn, were slow in making their way down Gillem's bluff and getting organized into a line of skirmishers as they advanced toward the stronghold. No doubt Modoc scouts were fully aware of the troop movements since early dawn, but it was after $11 \mathrm{a} . \mathrm{m}$. before Modoc snipers opened fire. The debacle that followed has been chronicled by many; the most detailed account of number of men, their positions, and their movements during the "battle" is in Thompson (1971, Chapter 4, p. 33-45). After wounding and killing several men the Modoc's relinquished a few of their outposts, thus leading the advancing troops eastward until they were enmeshed in the chaos of deep cracks and crevasses within the schollendomed area. Here the Modoc's fire from their natural defense trenches above was accurate and deadly; casualties mounted, and yet not an Indian had been seen by the befuddled troops. By midafternoon all thought of charging up onto the plateau was abandoned; some parts of the line were already in retreat leaving their dead on the field. Captain Green personally led an attempt to round the Stronghold along the lakeshore and make contact with Bernard's command on the east. They suffered many casualties; most retreated or were killed, but a few men remained concealed behind boulders until

darkness, and then made their way over to Bernard's position. Captain Green was among them.

Bernard's group had also been in trouble during the day. Casualties were inflicted by unseen Modoc snipers. The terrain, although not as difficult as that on the west side, is extensively schollendomed, and in places it contains treacherous groups of crevasses. After learning by signals that the assault on the west side had failed, a more orderly retreat was begun at $10 \mathrm{p} . \mathrm{m}$. On the east side and it continued through the night.

The day after the rout the Modocs searched the battlefield and recovered much valuable booty (Riddle, 1974, p. 56). They found the ground covered with ammunition, rifles and other kinds of guns where the oregon volunteers had stampeded in bad order. In the area where most of the casualties of the soldiers had occurred were 9 carbines and 6 belts filled with carbine cartridges. Also recovered was considerable field equipment, boots and clothing.

The outcome of the January 17 assault was thus a spectacular victory for the Modocs. Casualties of the Army and the Oregon and California volunteers totaled 37, and 6 of the dead were left on the field. The Modocs had no casualties. In Thompson's words (1971, p. 43) "Three hundred men had been unable to make the slightest dent on the magnificient union of lava and Indian skills."

In many written accounts the heavy fog is blamed for the Army's debacle, but a person thoroughly familiar with the terrain can argue effectively that the fog worked to the advantage of the Army, not the Modocs. The Modocs early defense was accomplished entirely by snipers in Modoc outposts. From their secondary natural defense trenches at the top of the plateau, other Modoc defenders could not see through the fog and determine which parts of the Army's line were hung up on fissured ground, which parts were advancing, and which were routed and in retreat. Therefore they could not concentrate their limited manpower to the points where it would be most effective - as they did so successfully later in the disastrous Thomas-Wright ambush.

The Winter Program of "Gradual Compression". The events between January 18 and April 11, 1873 are well summarized in Murray (1968) and additional detail can be found in Thompson (1971, p. 45-65). The Modoc Shaman (Curley Headed Docter) had assured the warriors that they were invincible, and would not suffer a single fatality. After the easy repulse of the January 17 attack they had every reason to believe him. The Army was humiliated. Changes in command took place: Brigadier General E. R. S. Canby and Colonel Alvan C. Gillem were placed in charge, and steps were taken to greatly increase the number of soldiers. The Oregon and California volunteers, who had been so eager to do battle prior to the January 17 assault now had their fill of fighting the Modocs; most of them disappeared the moment their 30-day enlistment was up. Irresolute and conflicting orders also came from the War Department in washington, D.C. A strong feeling arose that it might be better to try to negotiate with the Modocs than to engage them in battle. A Peace Commission of 5 members was set up, but rapid changes occurred in its membership, and the Commission did not truly have the power to give answers with regard to the Indians two chief concerns: l. Establishment of a small reservation for the Modocs in the Lava Beds; 2 . Escape from the hangman's noose for those who had murdered the Oregon settlers after the Lost River confrontation. Moreover the Indians were growing increasingly concerned with the steady build up of troops nearer and nearer to their stronghold. Canby was engaged in a program of "gradual compression." By early April, Gillem's Camp, at the southwest corner of Tule Lake, and only 3 miles from the Stronghold, contained 350 soldiers. On April 6 Captain Mason moved 5 companies of foot soldiers to Hospital Rock, only 2 miles to the east. 
Dissension about future tactics also arose in the Modoc's camp. From their point of view the meetings with the peace Commission had been completely fruitless, and immediately after each meeting Canby had moved additional troops nearer to the Stronghold. This program of "gradual compression" after each meeting could only lead to frustration, and a final explosion of the Modocs.

One of the Modocs proposed that one more peace meeting be held at which General Canby, A. B. Meacham, the head of the Peace Commission, and the other members in attendance would be murdered. This audacious idea captured the fancy of many of the Modoc warriors. They reasoned that if the General in charge of operations, and the head of the peace Commission were simultaneously put out of the way the soldiers might withdraw. Captain Jack knew better, and vigorously opposed the plan, but some of his colleagues taunted him as a coward, pushed him to the ground, and placed women's clothing upon him. His manhood thus called into question, Jack agreed with the plan, and said that he would be the one to murder Canby.

This treacherous plan was learned by Toby Riddle (Winema), a Modoc woman married to a white man, Frank Riddle. The Riddles had served as interpreters during the Peace negotiations. She warned Canby and Meacham of the plan and begged them not to hold another meeting. They did refuse a meeting for the following day, but after Captain Jack formally requested a meeting for April 11, to be held in the "peace tent" located between Gillem's Camp and the Stronghold, Canby agreed. He "assured the Commissioners that the Modocs would 'dare not molest us because (our) troops commanded the situation'" (Thompson, 1971, p. 59).

The meeting waș held. Canby and Jack immediately argued over peace terms. Jack gave the sign, pulled his gun, and killed Canby. Simultaneously Thomas was killed. Meacham was shot several times, but survived because Toby Riddle deflected Schonchin John's aim. She also stopped an attempt by Boston Charley to scalp Meacham. L. S. Dyar and Frank Riddle ran the moment Jack pulled his gun, and each successfully evaded bullets fired by pursuing Modocs.

Assault of April 15-17, 1973. The tragedy of April 11 spurred both the War Department and the local Army command into action. Gillem's and Mason's soldiers were already poised on either side of the stronghold. Mason had $300 \mathrm{men}$, and in addition 70 Warm Springs Indians were riding from their reservation to the north to join him as scouts in time for the battle. The western command under Colonel Gillem and Captain Green already had 375 soldiers at Gillem's Camp. Surely 675 troops plus 70 Indian scouts was sufficient to capture or exterminate 53 Modoc warriors! Wheaton had realized that Coehorn mortars would be more effective than the low-trajectory howitzers in displacing the Modocs from caves and rock trenches. Many mortars had arrived and were ready to be moved into action. Wheaton, from his January 17 experience, had also passed on to his successors that the east side of the Stronghold was much more vulnerable to attack than the west side, but this excellent advice was totally disregarded.

Gillem set April 15 for the assault. Its planning, execution, and final results were almost a carbon copy of the assault of January 17 th, except that this time the scenario was played in slow motion. On the night of April 14-15 the soldiers edged gingerly forward in the darkness until they occupied roughly the same positions that the troops of January 17 had reached when they came under Modoc fire. But in this second assault the troops were prepared to stay and hold on. As the troops on the west side were moving into position under cover of darkness a soldier lost his footing among the jagged rocks and his rifle accidentally fired. Thus the Modoc's were alerted, and their cries of warning were passed along throughout the perimeter of the stronghold. The soldiers immediately bivouacked in place, throwing up rock forts as shelters.

The soldiers on the east side had already constructed numerous low forts of loose rock, and a rock-wall line of defense before the date for the assault was set. The lesson of the value of rock shelters had been well-learned in the January 17 assault. When the Modocs cried out their alert, the troops on the east paused for the night in these shelters.

The next day (April 15) mortar and howitzer shells were poured into the Modoc's encampment, and the troops began a cautious and slow advance. They immediately drew the Modoc's fire. Some success was attained in the early afternoon when Green's troops displaced a few Modoc snipers, who escaped safely to their defense trenches on the margin of the plateau, but not until they had taken a toll of casualties from the advancing troops. As the night of April 15-16 approached, Green ordered his troops to straighten their line and build forts of loose rock, or else find shelter in rock crevices for the night. The advance on the east side had been even more slow and cautious. Throughout this night the artillery sent bursts from their mortars and howitzers toward the Modoc encampment.

On the second day of fighting (April 16) the artillery continued to pour mortar and howitzer shells into the Modoc's lair, and the foot soldiers advanced slowly. An attempt to push forward strongly on the south flank of the west side failed completely. On the eastern front Mason's troops came under sniper fire from their rear as well as in the direction of advance, and were pinned down for most of the day. It became obvious that it would be too costly to try to take the Stronghold by direct charge. The strategy was changed to attempting a simultaneous advance along the lakeshore which would cut off the Modoc's water supply. Reports disagree on whether a real junction of the two forces was made, but at least the soldiers approached close enough to bring any Modoc seeking water under fire. Throughout the night mortar shells were lobbed continuously at the Modoc's positions, and this activity was doubtless far more effective than the desultory and inaccurate rifle fire of the foot troops against an enemy that they could not see. At any rate, it was during this night that the women, children, and most of the Modoc warriors withdrew to the south, undoubtedly following the well-known route across the flat-topped remnants of the lava plateau along which the Modocs had driven cattle into the natural corral. A few Modoc warriors remained through most of the night to harass and taunt the troops "in very plain, if not classical English" (Thompson, 1971, p. 74).

On the morning of April 17 the artillery stopped pouring shells into the stronghold, and troops on both east and west sides began a cautious advance. No sounds came from the Modoc's position, no shots 
were fired, and so soldiers in parts of the Army line advanced more rapidly and soon were on top of the plateau within the Stronghold area. They found it completely deserted. Many soldiers, however, delayed and were still hiding behind their rock shelters. colonel Gillem, angry at their unwillingness to fight "got upon the highest rock available and ordered repeatedly 'Forward,' 'Forward," until finally Mason's Troop G under Captain Bernard came up to join with Green in sweeping the area." (Thompson, 1971, p. 75).

It was an empty "sweep." Over 650 Army regulars had spent 3 days and 3 nights in "battle" and had suffered 23 casualties ( 6 killed, 17 wounded). Their attempt to "round up" or else "exterminate" the Modocs was a complete failure, even though they now occupied the Modoc's Stronghold.

The Modocs, however, had suffered a few casualties as well, and so the Shaman's pronouncement of invincibility was discredited. It is reliably reported that one Modoc warrior was killed by a mortar shell, and very likely two additional Modocs died from the shelling. Sergeant Fitzgerald reported that the severed head of a Modoc was being kicked about by the troops after their entry into the Stronghold, and William Simpson, an English newspaper reporter, drew a picture of a soldier holding the scalp of a Modoc man, erroneously reported to be Scar-Faced Charley (who, however, was still alive and out of the Stronghold). One aged Indian squaw, crawling through the rocks in an attempt to get to water was captured, and then summarily shot through the head. In this war savagery was not restricted to people of one culture or one color.

The Modoc's Withdrawal Route. Much nonsense has been written in Army Reports, as well as by historians and other writers, about the route by which 150-170 people, mostly women and children, were able to escape from the stronghold undetected. It was inconceivable to the Army command that they could slip away so silently in the night without the soldiers' knowledge. The Warm Springs Indians, hired as mercenaries, were suspected of being traitors to their contract and of allowing the Modocs to "escape up a gulley," near the line that the Warm Springs held at the southeast end of the eastern front. Historians, as well, have appealed to the finger-like collapse draws south of the Stronghold, plus connivance with the Warm Springs scouts. Yet an observer who walks through these draws on the ground finds them so cluttered with schollendomes and riven with deep cracks and crevasses that it would be quite impossible to get such a large group through, along with their dogs and horses in one night's time. Even more fanciful are the written statements in some serious reports that the Modocs "slipped past the Warm Springs scouts in a large lava trench" (no such "trench" or "gulley" is there), or the less ambiguous (but quite impossible) statement that they

"disappeared into the Schonchin Flow."

To a topographic engineer or to a geologist equipped with modern airplane photographs of the terrain, the escape route of the Modocs is obvious. They simply walked south and then southeast at a brisk pace on the remnants of the surface of the lava plateau (see map), avoiding the collapse basins which dimple parts of the plateau, and the turndown flaps and schollendomes which clutter the borders of the plateau remnants. The route is precisely the same as the one along which the Modocs had driven over 100 stray and stolen cattle into the natural corral from the plains and highlands to the southeast.

In the area of our map the northern end of this trail is shown by a broken line symbol. Note that its closest point to the Warm Springs position is about $1 / 2$ mile ( 750 meters) but that it is not far from the Modoc natural defense trenches at the top of the turndown flap on the west edge of the plateau. Here the Modocs had totally broken an effort of the soldiers to "push forward strongly" during the previous day's fighting.

Rock Fortifications Constructed by the Army. Where had the Modocs gone? Would they return? Was their disappearance only a ruse preliminary to a surprise attack? Colonel Gillem and his troops did not know. It was obvious that a few Modocs were still around, for the occasional crack of a sniper's rifle was heard, and now and then an Indian could be seen out of rifle range walking on the southern plateau remnants, and others bathed in the lake. So the next few days after the occupation were spent in hastily throwing up rock forts and rock walls for defense in case the Modocs decided to return. Over 200 of these fortifications have been located and are large enough to be shown by appropriate symbols on our map. Another 30 or 40 , including a long but discontinuous rock wall, were put up by Mason's troops before the April assault - they constitute the easternmost line of forts and walls shown on the map.

During this activity the troops also discovered that the easiest travel in the area is on the surface of the lava plateau, and they selected and fortified with 10 larger and stronger "hollow-square" forts an east-west line of easy travel across the plateau remnants south of the Modoc's former living quarters. The outer trail, constructed by the Park Service, follows this line of forts in its east-west course (see map).

The Thomas-Wright Ambush. Colonel Gillem decided to send out patrols in an attempt to $\mathrm{f}$ ind out where the Modocs had gone. Bernard headed a cavalry patrol to the east and northwest, and a second patrol under Perry rode to the southeast on the same day. Near Dry Lake some warm springs Indians, riding with Perry, caught, killed and scalped two Modocs. When the Warm Springs returned on April 21 they also brought information that some Modoc warriors were in the Lava Beds about 4 miles south of the stronghold near a light colored butte (now known as Hardin Butte). Gillem first sent a small patrol to investigate, and then decided to send a large patrol to see if it was feasible to set mortars on Hardin Butte to shell the Modocs in their new hideout. It seems clear from other evidence that only a few Modoc warriors were near Hardin Butte. The route of withdrawal of the Modocs was southeast toward Big Sand Butte and Dry Lake.

The large patrol started for Hardin Butte from Gillem's Camp on April 26. Captain Evan Thomas, son the Adjutant General (retired) Lorenzo Thomas, was in charge. With Evans were the sons of two other Army Generals: Lieutenant Thomas F. Wright and Lieutenant Albion Howe. None of the three had any experience fighting Indians. The patrol moved along slowly from Gillem's Camp, and just before noon they entered an amphitheater bounded by low ridges on the east, south, and west, and located near the west base of Hardin Butte. It is reported that "old hands" among the foot soldiers had been worried on the march by the lack of experience of the officers, and by the careless way in which the patrol trudged along in a 
compact column without deploying skirmishers to the sides. Indeed it is reported that sergeant Romer became disgusted, climbed up the ridge on the west and acted as a flanking guard for part of the journey.

When the patrol reached the floor of the amphitheater Captain Thomas called a halt for lunch. The troops sat in small groups on the sandy ground, and many took their boots off. While the men were resting and eating, Captain Thomas with three other soldiers began to climb the low $r i d g e$ on the south at the head of the amphitheater. Before they had gone far rifle fire came from the very pile of rocks that they had set out to reach. Lieutenant Wright reacted at once by ordering a "set of fours" up the ridge to the southeast; these four men immediately were fired on; they turned and ran back to Wright's position in the middle of the amphitheater. Thomas then ordered Wright to advance with all of Company $E$ onto the opposite ridge (west of the amphitheater). Again the Modocs fired from rock piles in the top of this ridge, but wright and some of his men continued, only to die in the attempt. Others turned and ran. Meanwhile Lieutenant Cranston had taken 5 men to the northeast, hoping to climb high enough onto Hardin Butte to signal Gillem's Camp. All six were killed when they reached the Butte.

The soldiers in the amphitheater were in a state of confusion - many broke and ran toward Gillem's Camp. Those who remained were pinned down on the sandy floor with little or no protection by either rocks or bush. Most were killed or wounded. Although the first survivor of those who ran reached Gillem's Camp before 2 p.m., his story was not believed. Rescue parties were not organized or under way until nearly dark. It was the following day before they picked up the wounded, and buried the dead at the points were they found them. No Modocs were at hand to contest the operations. The return to camp was not attempted until after dark. It was shortly after dawn on April 28 when they straggled into Gillem's Camp.

This stunning victory of the Modocs was accomplished by Scar-Faced Charley with only a few men. Most of the Modoc warriors were on the other side of the Schonchin Flow, far to the southeast. Charley's small band evidently remained behind to check on what was going on in the stronghold and at Gillem's Camp, and also to protect the rear of the departing Modoc's. It is likely that he had less than a half dozen men, and they may have staged the ambush on the spur of the moment because of the fear of being trapped against the west wall of the Schonchin Flow. The only crossing of this flow that is negotiable without hours of slow plodding over treacherous loose lava blocks is just north of the base of Hardin Butte.

From the standpoint of the Army the results of this battle are succinctly summed up in a report from Lieutenant Jocelyn, stationed at Camp Warner: "We have sickening news again from the Lava Beds."

Twenty-five men were killed, and 16 wounded most of them seriously. In historian Thompson's words (1971, p. 91): "Two-thirds of the patrol had fallen victim to the Modocs accurate rifle fire. The rest had run." Again a ring of rock clefts and loose boulders in a schollendomed area had been used with expert precision by Modoc snipers.

Dissension, Flight, Betrayal, and Surrender. Why had the Modocs left their natural fortress? We surmise that two events may have played important roles. Obviously the slow inward "Program of Gradua compression" had its effect in generating frustration and fear. But very likely the shelling by mortars and howitzers during the April attack was the real cause which forced the Modocs to withdraw. During the day and night of April 16 it is reported that the lobbing of shells into the Modoc encampment was almost continuous (Thompson, 1971, p. 72-73). The effects of such shelling on a resident population including women and children was heightened by the fact that the shells also killed one or more warriors. The Shaman's claim that Modoc defenders would never die in battle was proved incorrect.

No matter what the reasons, the task of the Army in rounding up the Modocs now became one of movement and fluidity, instead of a siege. In this new situation the Modocs, deprived of nearby sources of water and food, and encumbered by women, children and the aged, could not forever withstand the probing of cavalry patrols from a well-equipped and well-fed army of over 1,000 men. Nevertheless the retreating Modocs were still a dangerous force to cope with. an May 7 they raided a train of 4 wagons, drove of $f$ its escort of 15 to 20 men - 3 of whom suffered wounds and captured 11 mules and 3 horses. The wagons were empty - the train was on its way to pick up quartermaster supplies - so the Modocs burned them. Three days later, at dawn on May 10, the Modocs surrounded an Army patrol camped for the night near Dry Lake. This time, however, the soldiers stood their ground and drove the Modocs off. Eight troops were wounded, 3 of whom later died, but the Modocs also lost two men killed, one of them the popular leader Ellen's-Man George.

Dissension and betrayal now became important factors in bringing the fighting to an end. The Modocs quarreled bitterly after the Dry Lake battle, and split into two camps. One group who formerly lived mainly along Hot Creek, near Dorris, turned west toward their original homeland. The other and smaller group under Captain Jack remained for the present in the neighborhood of Dry Lake and Big Sand Butte. Army patrols continued to reconnoiter through this area for days, occasionally seeing one or more Modocs. Rock fortifications that the soldiers put up near Dry Lake and south of Big Sand Butte are numerous, and well preserved to this day. Moreover, the visitor who will search out the highest points on this nearly flat plain generally will be rewarded by finding the open fretwork of stones with which a Modoc sniper had camouflaged his observation position.

The Hot Springs group $r$ an into trouble while traveling west. Colonel Jefferson C. Davis, who succeeded to Canby's command, arrived in the lava beds on May 2. He soon broke up the large concentrations of soldiers at Gillem's Camp, the Stronghold, and Hospital Rock into many roving patrols of large size who would live in the Lava Beds "where they could fight at the first opportunity, or could rest and take things easy, like the Indians." Two such patrols picked up the trail of the Hot Creek band. One caught up with and gave chase to the Indians - who scattered in all directions through the rocks, mountain mahogany, and junipers. But 5 Modocs were killed - 3 women and 2 men - and several women, children and horses were captured. Davis ordered his units to regroup, and then continue to harass these Indians, but before they could again take up the chase some Modocs came to the Fairchild Ranch and reported that the Indians wanted to surrender 
(Thompson, 1971, p. 105; Riddle, 1974, p. 128). Davis sent two Indian women that he had employed on other missions to seek out the Modocs and give them the terms of surrender.

John Fairchild and his wife also went up the mountain with them. After a short discussion scar-Faced Charley took the lead in persuading his people to surrender without further bloodshed. Eventually 63 Modoc men, women and children came off the mountain and surrendered. They were a sorry-looking group: clothes in tatters; many lame, sick or injured; and "half-naked children and aged squaws who could scarcely hobble". Hooker Jim, "the Lost River murderer," was not among them, but he came in and surrendered a little later.

Davis' avowed purpose, however, was to catch Captain Jack and to hang him forthwith for the murder of Canby. He lost no time in accelerating the search. Davis had learned the value of hiring Indians to catch Indians, so he immediately hired Steamboat Frank, Hooker Jim, Bogus Charley, and Shacknasty Jim to find Captain Jack (Thompson, 1971, p. 110; Riddle, 1974, p 164). These were the very same Modocs who had taunted Captain Jack into killing Canby. Davis also sent along the two Indian women who had helped arrange the surrender of the Hot Creek group.

Within a week these Modocs, now turned informer, and riding well-fed Army horses, had located Captain Jack's band camped along Willow Creek in a wild and mountainous area east of Clear Lake. A large contingent of troops moved in, and while the traitor Bogus Charley was talking with Captain Jack about surrender, the troops came upon the Indian camp a few hundred meters away and fired a volley of shots into it (Riddle, 1974, p. 147). The hunted Modocs scattered, leaving most of their guns, ammunition, and equipment. Eight Modoc women and some children were taken prisoner, among them Jack's two wives and child. Jack and a few others dashed into a thicket of willows, waited until darkness, and then escaped.

The chase continued. Before it was over Jack and the few members still left in his band had raced approximately 200 miles, first in the rough country along willow Creek, then to Langell valley and Bryant Mountain in Oregon, and back to clear Lake and the lower part of willow Creek again. But the odds against survival were too overwhelming; the mounted patrols, now aided by skilled Indian trackers, had picked up his trail at many points, and on June l, 1873 they closed in. Again Scar-Faced Charley helped in pursuading both Modocs and soldiers to refrain from further bloodshed. Captain Jack, along with two men, three women, and several children surrendered. Another Modoc warrior, Ben Lawver with his wife, boy, and aged father and mother came in a few days later.

The remainder of the Modoc's story is a record that contributes little of honor to either victor or vanquished. Davis, intent on revenging Canby, planned to hang Captain Jack publicly within a few days after capture, but he was frustrated by a ruling from Washington that penalites must be decided by the courts. The results of the trial were predictable. Captain Jack, Schonchin John, Boston Charley, and Black Jim were hanged. Slolock and Barncho, who also were in the vicinity of the peace tent but did not take part in the actual killings, were sentenced to life at Alcatraz. Five wounded Modoc prisoners were killed by two unknown assasins while being transported to jail at Fort Klamath. Another Modoc comnitted suicide after capture. The remaining Modocs, 155 men, women, and children, were banished to a barren tract of land, 5-3/4 square miles in area ( 2.5 miles on a side) near the Quapaw Indian Agency in Oklahoma. Confinement, disease, and poverty then accomplished more than had the efforts of over 1,000 troops. Some few survivors were given permission to return to the Klamath Reservation in oregon after 1909.

The Modoc's eternal monument is the natural fortress of the stronghold, which remains just the same today as when it was formed by the congealing and creeping forward of a large flow of lava more than one million years ago.

\section{References}

Fuller, R. E., 1931, The aqueous chilling of basalt lava on the Columbia River Plateau; American Journal of Science, v. 21, p. 281-300.

Murray, Keith A., The Modocs and Their War: University of Oklahoma Press, Norman, 1958, 346 p. (An objective, interesting, and well-written account by a historian and sociologist who has served as a Park Ranger at Lava Beds National Monument).

Riddle, Jeff C., The Indian History of the Modoc War: First printed in 1914; republished in 1974 by Urion Press, Eugene, Oregon, 1974, 295 p.

(A fascinating book written in simple, straightforward language by the son of the Modoc woman Toby (Winema) Riddle, who served as interpreter during the peace meetings. Jeff Riddle knew all of the Modoc warriors and his reports of conversations among them in their own language give a vivid picture and a new dimension of many of the deliberations among the Indians, and also between Modocs and whites).

Thompson, Erwin N., The Modoc War: Argus Books, Sacramento, Calif., 1971, 188 p. plus illustraions and maps.

(A comprehensive account with particular emphasis on numbers, distribution, personnel, and objectives of the various military units engaged in a struggle. outstanding documentation by notes and references to many little known army, newspaper, and private records that are not easily available).

Waters, A. C., and Fisher, R. V., 1971, Base surges and their deposits: Capelinhos and Taal volcanoes; Journal of Geophysical Research, v. 76, p. 5596-5614. 
PRE-HOLOCENE SILICIC VOLCANISM ON THE NORTHERN AND WESTERN MARGINS OF THE MEDICINE LAKE HIGHLAND, CALIFORNIA

Stanley A. Mertzman

Department of Geology, Franklin and Marshall College, Lancaster, PA 17604

\section{Abstract}

The Medicine Lake Highland is an area of diverse volcanism whose extrusives span the last 1.5 to 2 million years of earth history. The enigmatic Andesite Tuff of C. A. Anderson (1941) has been provisionally placed into the general stratigraphic sequence as one unit within the collage collectively know as the "pre-Medicine Lake andesite" volcanics. This proposed positioning results from field, petrographic, and chemical evidence which suggests the existence of a series of andesitic lava flows that are coeval in age or slightly younger than the Andesite Tuff. One of these equivalent lava flows has given an age of $0.21 \pm 0.05 \mathrm{~m} \cdot \mathrm{y}$. old. If this correlation is accurate, then the conclusion that the Andesite Tuff represents an event which occurred prior to the initial eruptions of the Medicine Lake volcano is true and, therefore, the tuff cannot be correlated with the development of the Medicine Lake summit caldera.

Additional silicic volcanism, including rhyolitic domes and flows, is considerably older $(0.43$ to 0.95 m.y.); a fact which indicates no direct genetic link need exist between the rhyolites and the tuff. Lastly, the rhyolites can be divided into two separate groups on the basis of $\mathrm{SiO}_{2}$, neither of which overlaps that of the Holocene glass flows, a feature for which the Medicine Lake Highland is well known.

\section{Introduction}

Several recent summaries by Macdonald (1972) and Williams and McBirney (1979) concerning the origin of collapse calderas suggest a number of these features formed concurrently with the eruption of ash-flow tuffs. Noble (1969) suggested that such a relationship may in fact explain the origin of the Medicine Lake caldera in northern California. In particular he proposed that a unit known as the Andesite Tuff may correlate with the collapse of the Medicine Lake caldera and, therefore, post-date the extrusion of the "older shield-forming andesite" unit of C. A. Anderson (1941). This interpretation was also reiterated by A. T. Anderson (1976). On the other hand, Mertzman (1977) interpreted these olivine andesite lavas as the initial eruptions of the Medicine Lake volcano and therefore necessarily pre-caldera in age, a conclusion similar to that of C. A. Anderson (1947). These contradictory interpretations are abetted by a lack of outcrop in critical areas and the inability to obtain a reliable $\mathrm{K} / \mathrm{Ar}$ age date from the Andesite Tuff, a difficulty arising from its large scale atmospheric argon contamination. However, field mapping by Walter

(1975) and Mertzman (unpublished data) indicate the existence of andesitic lavas which appear to be coeval with the andesitic ash-flow tuff unit. Subsequent analytical studies concerning these tuff-equivalent lavas has apparently resolved the contradictory interpretations previously outlined and provides a rudimentary stratigraphy on which to build future research in the Medicine Lake Highland.

\section{Geologic Setting}

The Medicine Lake Highland, located approximately $50 \mathrm{~km}$ east-northeast of Mount Shasta in northern California, is the southern extension of a discontinuous belt of shield-like composite volcanoes which lie 30-50 km east of the High Cascade stratovolcanoes. The northern extension of this belt includes Newberry volcano in central Oregon and Simcoe volcano in south-central Washington. Previous research in the Medicine Lake Highland has been recently summarized by Mertzman (1977) and Heiken (1978), and so the writer will present only the highlights of the geologic history. Over the past several years three dozen $\mathrm{K}-\mathrm{Ar}$ analyses have been performed as part of an ongoing attempt to ascertain the geochronologic development of the region surrounding the Medicine Lake Highland and extending toward Mount Shasta. To date, all the samples from within the region covered by Figure 1 are less than two million years old. The oldest lavas are the basaltic rocks of Timber Mountain volcano, which is located just of Figure 1 approxiately 9 miles southeast of Lava Beds National Monument. These lavas range from 1.7 to 1.9 million years old. Thin flows of low potassium high-alumina olivine tholeite are well exposed along the portion of Gillem's Bluff fault scarp within Lava Beds National Monument and vary from 1.0 to $1.4 \mathrm{~m} . \mathrm{y}$. old. In addition, numerous olivine tholeiite flows of nearly identical petrography and chemistry outcrop both around the periphery and intercalated with lavas of the Medicine Lake Highland and range in age from approximately 1.4 m.y. old to Late Pleistocene to Recent. Moving from the Highland westward there are approximately a dozen mostly andesitic composite volcanoes within the Bray, Dorris and Mount Dome quadrangles whose ages fall between 0.3 and $1.3 \mathrm{~m} . \mathrm{y}$. old. It is within the context of this volcanic history that the silicic igneous activity on the northern and western margins of the Highland must be viewed and its origin eventually explained.

\section{DATA}

\section{$\mathrm{K}-\mathrm{Ar}$ results}

The $\mathrm{K} / \mathrm{Ar}$ data are shown in Table 1 with the exact sample locations depicted in Figure 1. Potassium was determined together with all the other major elements utilizing a lithium tetraborate fusion which results in a one inch glass disc. The actual analysis was 


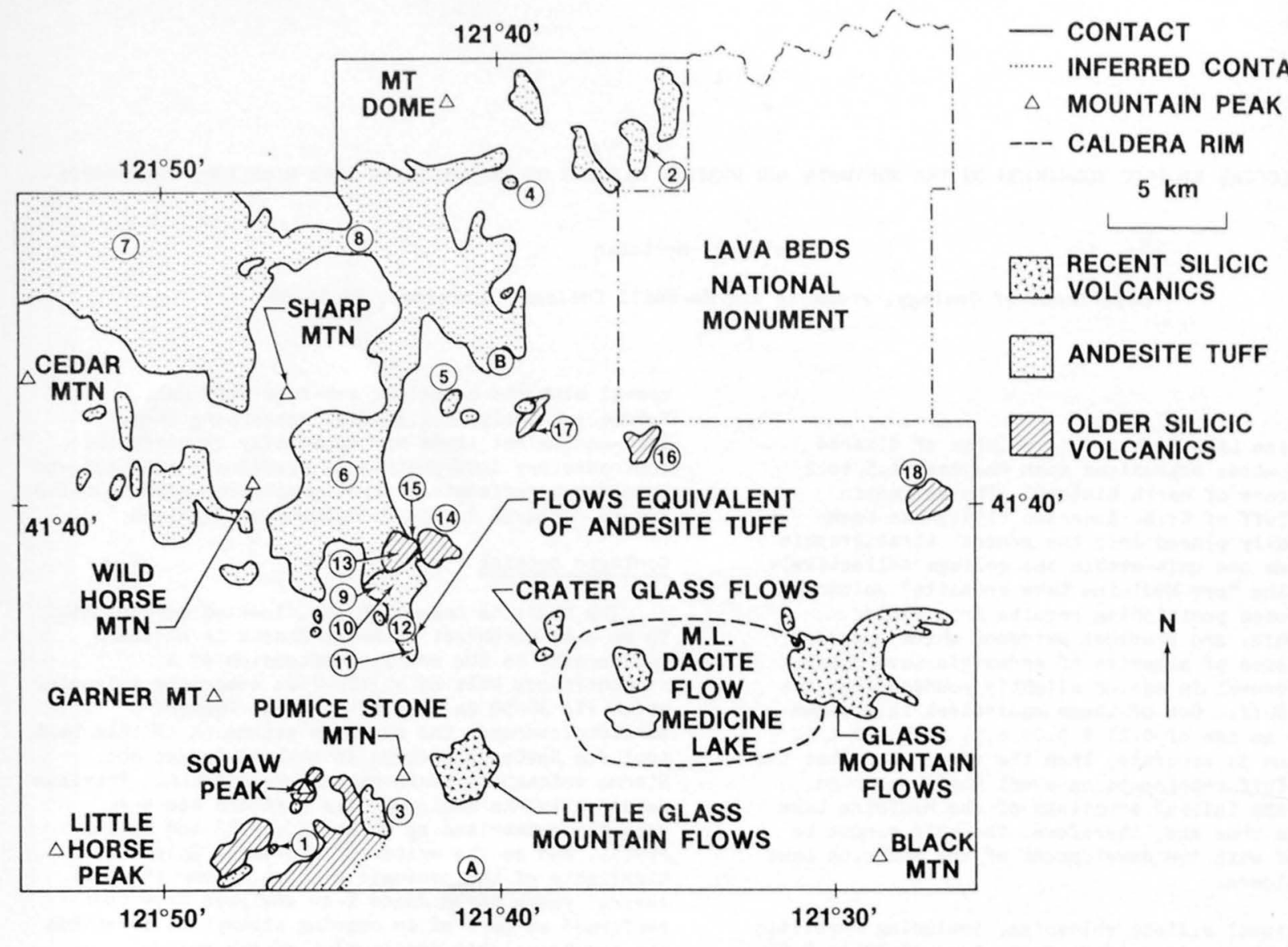

Figure 1. Geologic map of selected rock units from the Medicine Lake Highland area. The stratigraphic column is based in part on $\mathrm{K} / \mathrm{Ar}$ dating.

performed using an automated vacuum X-ray fluorescence spectrometer. Argon was determined by pipette-spiking with $38 \mathrm{Ar}$; the isotopic measurements performed with a MS-10 mass spectrometer. This instrument displays virtually no memory and no mass 36 background. The argon fusion was carried out on 3-6 grams of $8-42$ mesh fragments of whole rock which had been ultrasonically cleaned in distilled water and alcohol, dried in an oven and pre-baked in a vacuum at $250^{\circ} \mathrm{C}$. The uncertainty in the age is estimated utilizing a $0.3 \%$ uncertainty in the argon spike, a $2 \%$ uncertainty in sample homogeneity, and an absolute uncertainty in the potassium of $0.01 \% \mathrm{~K}_{2} \mathrm{O}$.

The silicic rocks dated in this investigation are from rhyolitic flows and domes. The contact relationships between the domes and the surrounding volcanics generally provide rather inconclusive information. These rhyolites range from 0.43 to 0.95 m.y. old with relatively small uncertainties. This spread of ages falls within the range previously quoted for the composite volcanoes located generally west of the Medicine Lake Highland. Any theory which attempts to explain the petrogenesis of this region over the past two million years must come to grips with this space-time-composition relationship which exists between these two groups of volcanic rocks.
The Andesite Tuff is the one major ignimbritic unit in the region and its areal distribution is outlined in figure 1 . In general, it is a poorly welded ash-flow tuff that completely lacks any stratification. However, where the base is exposed (e.g. in the southern portion of the area now known as the "Bighorn Sheep Enclosure" on Gillem Bluff) substantial flattening of pumice lapilli has occurred together with significantly more welding. The writer has made three attempts to radiometrically date this unit using a moderately welded sample, a poorly welded sample, and a plagioclase separate (no potassium feldspar present). None of these attempts were successful due to large scale atmospheric argon contamination. Subsequent detailed field work in the area south of Dock Well by Walter (1975) and myself (See portion of figure 1 delineated as "Flows equivalent of Andesite Tuff") led to the isolation of several andesitic flows which appeared to be the same age or slightly younger than the Andesite Tuff. Petrographic and chemical studies supported the mapping interpretation which has been further substantiated by reconnaissance microprobe mineral analysis. These data indicate that smooth compositional gradations as well as a large measure of overlapping occur between the proposed equivalent lava flows and the tuff with respect to the orthopyroxene, clinopyroxene and plagioclase feldspar. In fact, the plagioclase phenocrysts which 
TABLE 1. Analytical results of $\mathrm{K}-\mathrm{Ar}$ dating. ${ }^{\mathrm{a}}$

\begin{tabular}{|c|c|c|c|c|c|}
\hline $\begin{array}{l}\text { Sample } \\
\text { Number }\end{array}$ & $\begin{array}{c}\text { Map Location } \\
\text { Number }\end{array}$ & ${ }^{40} \mathrm{Ar} \mathrm{b}^{\mathrm{b}} / \mathrm{g}$ & $\begin{array}{c}{ }^{40} \mathrm{Ar} b / 40 \mathrm{Ar} \\
\times 100\end{array}$ & $\begin{array}{l}\mathrm{K}_{2} \mathrm{O} \\
(\boldsymbol{\phi})\end{array}$ & $\begin{array}{r}\mathrm{K}-\mathrm{Ar} \text { age } \\
(\mathrm{m} . \mathrm{y} .)\end{array}$ \\
\hline
\end{tabular}

Rhyolite domes

$\begin{array}{llllll}\text { ML49 } & 18 & 0.0269 & 11.62 & 4.42 & 0.43 \pm 0.04 \\ \text { SM51 } & 17 & 0.0412 & 68.04 & 4.63 & 0.61 \pm 0.03 \\ \text { 56B1 } & 15 & 0.0443 & 5.55 & 3.18 & 0.95 \pm 0.14\end{array}$

Lava flow equivalent of Andesite Tuff

$\begin{array}{llllll}263 \mathrm{Cl} & 12 & 0.0065 & 3.18 & 2.14 & 0.21 \pm 0.05\end{array}$

Earliest Medicine Lake volcano lavas

$\begin{array}{llllll}366 \mathrm{~W} & \mathrm{~A} & 0.00115 & 2.12 & 0.85 & 0.09 \pm 0.05 \\ \mathrm{SM}^{\mathrm{C}}{ }^{\mathrm{C}} & \mathrm{B} & 0.00097 & 0.74 & 0.85 & 0.08 \pm 0.04\end{array}$

\footnotetext{
${ }^{\mathrm{a}}$ Constants used are: ${ }^{40} \mathrm{~K} /$ total $\mathrm{K}=1.167 \times 10^{-4} ; \quad \lambda_{B}=4.962 \times 10^{-10} \mathrm{yr}^{-1}$; $\lambda_{B}=5.81 \times 10^{-11} \mathrm{yr}^{-1}$.

${ }^{b}$ Radiogenic argon, $10^{-10}$ moles.

${ }^{C}$ The age is slightly different from that reported in Mertzman (1977) as a result of

recalculation with the new K-Ar age constants of Dalrymple and Mankinen (1979).
}

occur in both the flows and the tuff have virtually the same zoning pattern in addition to highly similar chemistries. One of the proposed tuff-equivalent lava flows gives an age of $0.21 \pm 0.05$ (Table 1). I submit that this age closely reflects the time of eruption of the Andesite Tuff and, at the very worst, reflects its minimum age.

The Andesite Tuff controls the topography on the northwest side of the Medicine Lake Highland onto which the earliest of the Medicine Lake basaltic andesite flows were extruded. Two stratigraphically equivalent lava flows, from the northwest and the southwest flanks of the Medicine Lake volcano ( $B$ and A respectively in figure 1) have given ages of $0.08 \pm 0.04$ and $0.09 \pm 0.05 \mathrm{~m} . \mathrm{y}$. old. Since these flows represent both the initial eruptions of the Medicine Lake volcano as well as the bulk of the extrusives which compose the Highland (equivalent to the shield-forming platy olivine andesite of C. A. Anderson, 1941) the conclusion can be drawn that the entire 900-1000 m thickness of lavas related to the Medicine Lake volcano (See Mertzman, 1977) has accumulated over the past 100,000 years. A corollary of this conclusion is that the caldera-forming event must be $<100,000$ years old; unfortunately no minimum age can yet be assigned since no rampart-forming andesite, which represents syn-to post-caldera volcanism, has heretofore been radiometrically dated - a void which will be filled over the next several months. Two additional points are worthy of note: since the stratigraphic thickness of the tuff noticeably increases in a southeasterly direction and yet it does not outcrop on the eastern and southern margins of the Highland, it seems safe in assuming that the vent area for the tuff lies buried beneath the younger andesitic lavas of the Medicine Lake volcano. Secondly, the gross age distinctions which exist between the rhyolitic domes and flows and the tuff-equivalent andesitic lavas on the northwest margin of the Highland, which differ by a factor of 3 to 4 , indicate separate pulses of volcanic activity rather than the rhyolite and the tuff being time correlative. The latter interpretation was suggested as a possibility by $C$. A. Anderson (1941).

\section{Chemistry}

Major and trace element chemistry was performed by $\mathrm{X}$-ray fluorescence spectrometry and the resulting data together with CIPW norms are reported in Tables 2 and 3 ; the exact sample locations are depicted in Figure 1. For trace element analysis one gram of dried whole rock powder was mixed with $0.5 \mathrm{~g}$ of microcrystalline cellulose and pressed into pellets using a course grade of cellulose as a backing. Trace element data reduction was achieved by the mass absorption correction method outlined by Hower (1959).

Analyses of the Andesite Tuff are found in Table 2; typically these samples have relatively large loss on ignition values, ranging from 1.87 to $4.52 \%$ by weight, a point which encouraged the writer to calculate the CIPW norms on the basis of recalculated analyses derived by normalizing to 100 percent 
Major and trace element chemistry together

with C.I.P.W. norms of the Andesite Tuff.

The exact sample locations are depicted in figure 1.

TABLE 2.

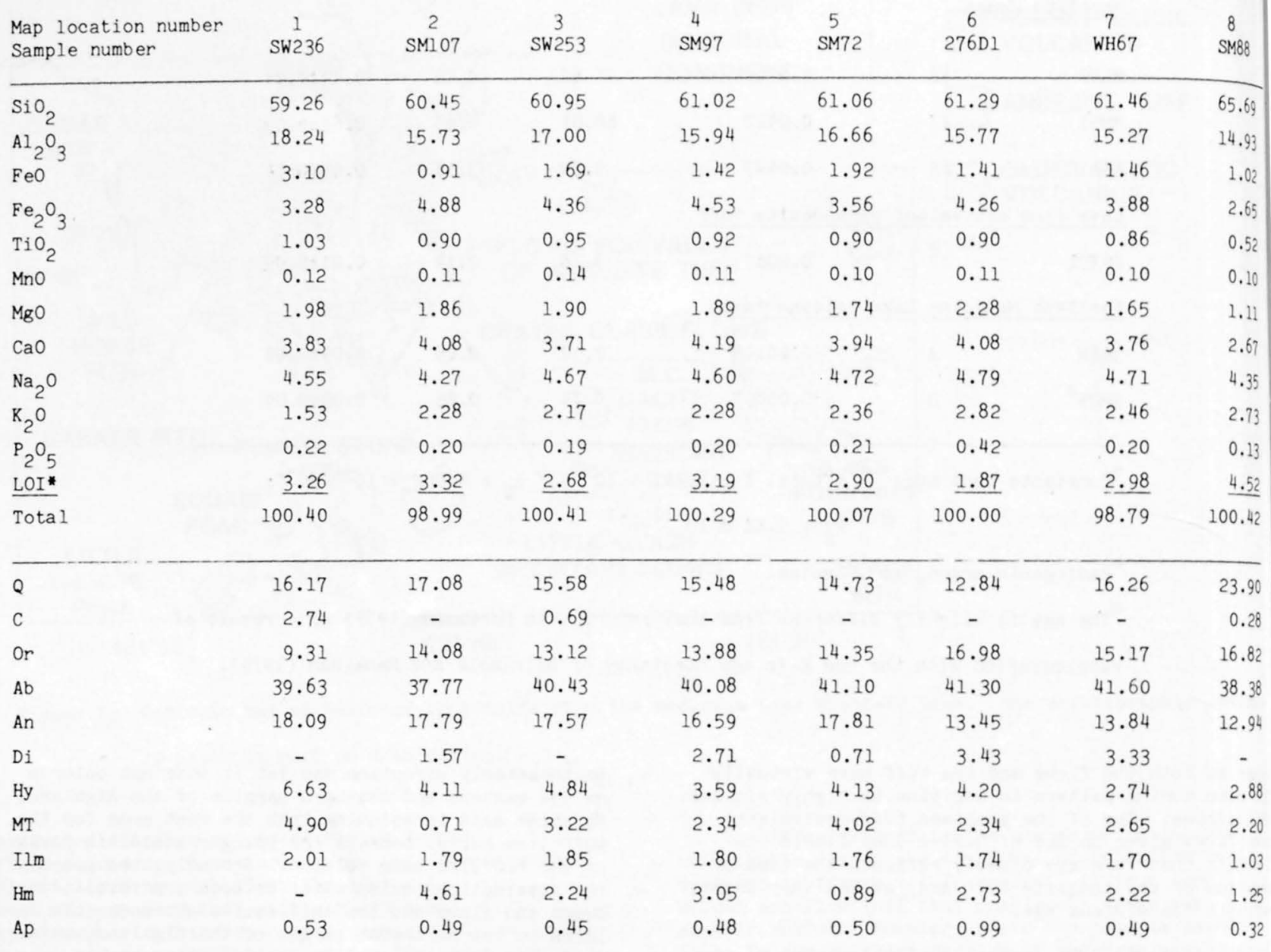

\begin{tabular}{|c|c|c|c|c|c|c|c|c|}
\hline $\mathrm{Rb}$ & 30 & 54 & 46 & 54 & 51 & 72 & 64 & 68 \\
\hline $\mathrm{Sr}$ & 373 & 389 & 373 & 387 & 394 & 377 & 360 & 293 \\
\hline $\mathrm{Ni}$ & 6 & 2 & 6 & 4 & 4 & 2 & 6 & 5 \\
\hline $\mathrm{Zr}$ & 275 & 262 & 260 & 255 & 263 & 242 & 273 & 213 \\
\hline $\mathrm{Ba}$ & 570 & 552 & 640 & 588 & 622 & 523 & 571 & 656 \\
\hline $\mathrm{Y}$ & 33 & 26 & 23 & 17 & 24 & 31 & 21 & 25 \\
\hline V & 115 & 101 & 99 & 121 & 106 & 72 & 94 & 30 \\
\hline $\mathrm{Rb} / \mathrm{Sr}$ & 0.080 & 0.139 & 0.123 & 0.140 & 0.129 & 0.191 & 0.178 & 0.232 \\
\hline $\mathrm{K} / \mathrm{Rb}$ & 423 & 351 & 392 & 351 & 384 & 325 & 319 & 333 \\
\hline
\end{tabular}

- Loss on ignition 
Major and trace element chemistry together with

C.I.P.W. norms of the lava flow equivalent of the Andesite Tuff (9-12). Also included are six analyses $(13-18)$ of older silicic volcanic rocks. The exact sample locations are depicted in figure 1.

TABLE 3.

\begin{tabular}{|c|c|c|c|c|c|c|c|c|c|c|}
\hline $\begin{array}{l}\text { Map location number } \\
\text { Sample number }\end{array}$ & $\begin{array}{c}9 \\
54 \mathrm{BI}\end{array}$ & $\begin{array}{c}10 \\
\text { ML57 }\end{array}$ & $\begin{array}{c}11 \\
259 \mathrm{Cl}\end{array}$ & $\begin{array}{c}12 \\
263 \mathrm{Cl}\end{array}$ & $\begin{array}{c}13 \\
\text { ML55 }\end{array}$ & $\begin{array}{c}14 \\
47 \mathrm{BI}\end{array}$ & $\begin{array}{c}15 \\
56 \mathrm{Bl}\end{array}$ & $\begin{array}{c}16 \\
\operatorname{SM} 38\end{array}$ & $\begin{array}{c}17 \\
\text { SM51 }\end{array}$ & $\begin{array}{c}18 \\
\text { ML } 49\end{array}$ \\
\hline $\mathrm{SiO}_{2}$ & 59.55 & 60.50 & 60.59 & 60.84 & 71.08 & 71.30 & 71.47 & 71.99 & 71.96 & $76 \cdot 38$ \\
\hline $\mathrm{Al}_{2} \mathrm{O}_{3}$ & 16.50 & 16.71 & 16.45 & 16.98 & 14.25 & 14.32 & 14.48 & 14.11 & 12.93 & 12.13 \\
\hline $\mathrm{FeO}$ & 4.36 & 1.88 & 3.74 & 4.56 & 0.70 & 1.07 & 0.91 & 0.60 & 0.82 & 0.70 \\
\hline $\mathrm{Fe}_{2} \mathrm{O}_{3}$ & 1.43 & 4.72 & 1.68 & 1.41 & 1.78 & 1.78 & 1.63 & 2.23 & 0.42 & 0.38 \\
\hline $\mathrm{TiO}_{2}$ & 0.74 & 0.91 & 0.69 & 0.79 & 0.32 & 0.44 & 0.31 & 0.45 & 0.21 & 0.05 \\
\hline $\mathrm{MnO}^{2}$ & 0.10 & 0.12 & 0.10 & 0.11 & 0.07 & 0.08 & 0.06 & 0.05 & 0.04 & 0.04 \\
\hline $\mathrm{MgO}$ & 3.16 & 2.66 & 2.89 & 3.45 & 0.53 & 0.42 & 0.51 & 0.34 & 0.08 & $<.02$ \\
\hline $\mathrm{CaO}$ & 5.56 & 4.88 & 5.25 & 5.74 & 1.74 & 1.92 & 1.66 & 1.24 & 0.86 & 0.46 \\
\hline $\mathrm{Na}_{2} \mathrm{O}$ & 3.58 & 4.18 & 3.69 & 3.85 & 4.73 & 5.10 & 4.78 & 4.87 & 4.06 & 4.46 \\
\hline $\mathrm{K}_{2} \mathrm{O}$ & 2.04 & 2.03 & 2.36 & 2.14 & 3.19 & 3.02 & 3.18 & 4.28 & 4.63 & 4.42 \\
\hline $\mathrm{P}_{2} \mathrm{O}_{5}$ & 0.19 & 0.17 & 0.19 & 0.24 & 0.08 & 0.11 & 0.09 & 0.08 & 0.04 & 0.01 \\
\hline LOI* & 1.49 & 1.48 & 1.21 & 0.72 & 0.98 & 0.95 & 0.87 & 0.36 & 0.29 & 0.44 \\
\hline Total & 98.70 & 100.24 & 98.84 & 100.83 & 99.45 & 100.51 & 99.95 & 100.60 & 99.34 & 99.47 \\
\hline
\end{tabular}

$\begin{array}{lllll}13.30 & 15.15 & 14.09 & 11.59 & 27.48\end{array}$

$26.09 \quad 27.68$

24.63

31.81

32.92

$\begin{array}{rrrrrrrrrr}12.40 & 12.15 & 14.28 & 12.63 & 19.14 & 17.93 & 18.97 & 25.23 & 27.62 & 26.38 \\ 31.16 & 35.81 & 31.98 & 32.54 & 40.65 & 43.34 & 40.82 & 41.11 & 34.68 & 38.11 \\ 23.59 & 21.10 & 21.87 & 22.71 & 8.24 & 7.30 & 7.72 & 3.99 & 3.42 & 0.03 \\ 2.89 & 1.79 & 2.89 & 3.43 & - & 1.21 & - & 1.27 & 0.55 & 1.83 \\ 12.63 & 5.88 & 10.60 & 13.01 & 1.34 & 0.49 & 1.28 & 0.26 & 0.81 & 0.07 \\ 2.13 & 3.86 & 2.49 & 2.04 & 1.58 & 2.44 & 2.25 & 0.79 & 0.61 & 0.56 \\ 1.45 & 1.75 & 1.34 & 1.50 & 0.62 & 0.84 & 0.59 & 0.85 & 0.40 & 0.10 \\ - & 2.12 & - & - & 0.72 & 0.10 & 0.09 & 1.68 & - & - \\ 0.45 & 0.40 & 0.45 & 0.56 & 0.19 & 0.26 & 0.21 & 0.19 & 0.09 & 0.02\end{array}$

\begin{tabular}{|c|c|c|c|c|c|c|c|c|c|c|}
\hline \multirow[b]{2}{*}{$\mathrm{Rb}$} & \multicolumn{9}{|c|}{ TRACE ELEMENTS (p.p.m.) } & \multirow[b]{2}{*}{148} \\
\hline & 56 & 48 & 59 & 54 & 77 & 67 & 63 & 123 & 128 & \\
\hline $\mathrm{Sr}$ & 438 & 412 & 415 & 433 & 176 & 234 & 131 & 91 & 70 & 2 \\
\hline $\mathrm{Ni}$ & 30 & 14 & 19 & 28 & ND & 3 & 3 & ND & $\mathrm{ND}$ & ND \\
\hline $2 r$ & 241 & 229 & 212 & 245 & 217 & 233 & 194 & 367 & 189 & 130 \\
\hline $\mathrm{Ba}$ & 575 & 528 & 523 & 542 & 737 & 728 & 729 & 790 & 664 & 85 \\
\hline Y & 33 & 30 & 24 & 19 & 28 & 20 & 18 & 48 & 54 & 99 \\
\hline V & 99 & 92 & 96 & 106 & 10 & 16 & 10 & 22 & 6 & ND \\
\hline $\mathrm{Rb} / \mathrm{Sr}$ & 0.128 & 0.117 & 0.142 & 0.125 & 0.438 & 0.286 & 0.481 & 1.352 & 1.829 & 74.0 \\
\hline $\mathrm{K} / \mathrm{Rb}$ & 302 & 351 & 332 & 329 & 344 & 374 & 419 & 289 & 300 & 248 \\
\hline
\end{tabular}

Loss on ignition

$\mathrm{ND}=$ not detected 
anhydrous totals. Cast in this light virtually all the tuff samples become more dacitic than andesitic in bulk composition. The only additional facet of their chemistry worthy of highlighting at this time is that three of eight samples are peraluminous. Comparison of the chemistry of the tuffs with that of the four samples for the proposed equivalent andesitic lava flows yields a pattern of lower $\mathrm{SiO}_{2}$ and $\mathrm{Na}_{2} \mathrm{O}$ and higher $\mathrm{MgO}$ and $\mathrm{CaO}$ for the lavas. Also, the percentage of phenocrysts is higher in the lavas than in the tuff samples (See Table 4). These trends are analogous to those reported from numerous other ignimbritic areas (e.g., Lipman and Others, 1966; Ratte and Steven, 1967; Christiansen, 1979), further substantiating this writer's claim of a co-genetic relationship linking the lavas and the andesitic tuff.

The rhyolitic volcanics form two distinct groups on the basis of their $\mathrm{SiO}_{2}$ contents: a low $\mathrm{SiO}_{2}$

TABLE 4

Modal analyses (volume percent). The data reported are average values ( 8 and 4 samples, respectively) which cover the entire range of petrographic variation within both the Andesite Tuff and the lava flows proposed as being equivalent to the tuff.

\begin{tabular}{lcc}
\hline Mineral & Andesite Tuff & Tuff equivalent lavas \\
\hline Olivine & Trace & Trace \\
Orthopyroxene & 3.2 & 3.9 \\
Clinopyroxene & 1.1 & 1.8 \\
Amphibole & Trace & - \\
Opaques & 2.3 & 1.2 \\
Plagioclase & 5.2 & 71.3 \\
Groundmass & 89.3 & \\
& & 21.8 \\
\hline
\end{tabular}

group (71-72\%) and a high $\mathrm{SiO}_{2}$ group (>74.5\%). Examining the age and chemical data concurrently produces a noteworthy correlation between decreasing age and increasing $\mathrm{SiO}_{2}$ content. Further documentation of this emerging pattern is presently underway. Whether or not this age-composition trend can be genetically linked to a viable crystal fractionation model awaits mineral composition data concerning phenocryst-forming phases, thus enabling some quantitative modelling to be performed. It is also intriguing to note that the chemistry of these older rhyolitic extrusives does not mimic that of the Recent silicic glass flow activity in the Medicine Lake Highland (Eichelberger, 1975; Heiken, 1978; Mertzman, in press). Table 5 presents average chemical analyses for the three Recent glass flows. It is evident that these data form a third group, intermediate between the two groups defined by the older silicic volcanism. Sufficient chemistry is currently available, all performed with the same analytical procedures, to probably eliminate insufficient sampling and analytical uncertainty as potential factors producing the clump-like patterns rather than a continuum of elemental variation. Whether or not this older episode (or episodes) of silicic volcanism is monogenetic or polygenetic, is research problem currently under study utilizing microprobe and isotopic techniques.

TABLE 5 .

Major and trace element analyses of three Holocene glass flows from the Medicine Lake Highland. ( $n$ : number of samples analyzed).

\begin{tabular}{|c|c|c|c|}
\hline $\mathrm{n}$ & $\begin{array}{l}\text { Little } \\
\text { Glass } \\
\text { Mountain } \\
\quad 5\end{array}$ & $\begin{array}{l}\text { Glass } \\
\text { Mountain } \\
4\end{array}$ & $\begin{array}{c}\text { Northwest } \\
\text { Glass flow } \\
3\end{array}$ \\
\hline $\mathrm{SiO}_{2}$ & 73.41 & 73.57 & 73.23 \\
\hline $\mathrm{Al}_{2} \mathrm{O}_{3}$ & 13.62 & 13.68 & 13.56 \\
\hline $\mathrm{FeO}^{\mathrm{T}}$ & 2.13 & 2.12 & 2.05 \\
\hline $\mathrm{TiO}_{2}$ & 0.27 & 0.27 & 0.28 \\
\hline $\mathrm{MnO}$ & 0.03 & 0.04 & 0.04 \\
\hline $\mathrm{MgO}$ & 0.35 & 0.22 & 0.30 \\
\hline $\mathrm{CaO}$ & 1.29 & 1.20 & 1.25 \\
\hline $\mathrm{Na}_{2} \mathrm{O}$ & 4.10 & 4.11 & 4.21 \\
\hline $\mathrm{K}_{2} \mathrm{O}$ & 4.28 & 4.29 & 4.28 \\
\hline $\mathrm{P}_{2} \mathrm{O}_{5}$ & 0.03 & 0.05 & 0.05 \\
\hline LOI* & 0.40 & 0.34 & 0.49 \\
\hline Total & 99.91 & 99.89 & 99.74 \\
\hline $\mathrm{Rb}$ & 159 & 162 & 154 \\
\hline $\mathrm{Sr}$ & 107 & 113 & 108 \\
\hline $\mathrm{Ni}$ & $\mathrm{ND}$ & ND & ND \\
\hline $\mathrm{Zr}$ & 229 & 215 & 223 \\
\hline $\mathrm{Ba}$ & 741 & 728 & 722 \\
\hline V & 6 & 8 & 3 \\
\hline $\mathrm{Rb} / \mathrm{Sr}$ & 1.486 & 1.434 & 1.426 \\
\hline $\mathrm{K} / \mathrm{Rb}$ & 223 & 220 & 231 \\
\hline
\end{tabular}

*Loss on ignition.

$\mathrm{ND}=$ not detected. 
Analytical data concerning the older silicic magmatic activity on the northern flanks of Medicine Lake Highland is presented. Available $\mathrm{K} / \mathrm{Ar}$ results give a 0.43 to $0.95 \mathrm{~m} . \mathrm{y}$. range for the rhyolitic volcanism, which can be divided chemically into low silica (71-72\%) and high silica $(>74.5 \%)$ groups. Both of these groups are clearly distinguishable from the Holocene glass flows with respect to chemistry. The areal extent and chemical variability of the Andesite Tuff is outlined. The past inability to radiometrically date the time of eruption of the tuff has tentatively been circumvented by analyzing one of several lava flows which were erupted concurrently with or very shortly after the tuff. The age of the equivalent flow is $0.21 \pm 0.05 \mathrm{~m} . \mathrm{y}$. old, a date that clearly establishes the eruption of the tuff as an event preceding the development of the Medicine Lake andesitic volcano and, therefore, not correlative with the formation of its summit caldera.

\section{ACKNOWLEDGEMENTS}

I thank the Research Corporation for a Cottrell College Science Grant, the Franklin and Marshall committee on Grants, and the American Philosophical Society for financial support of the field work. I also thank Dr. James Aronson of Case Western Reserve University for access to his K/Ar laboratory as well as for his timely advice. The automated vacuum $x$-ray fluorescence spectrometer was purchased with grants from the Pennsylvania Science and Engineering Foundation, the National Science Foundation, the Gulf Oil Company, and the Fleischmann Foundation.

\section{REFERENCES}

Anderson, A. T., 1976, Magma mixing, petrological process and volcanological tool; Journal of Volcanology and Geothermal Research, v. 1. p. 3-33.

Anderson, C. A., 1941, Volcanoes of the Medicine Lake Highiand, California: University of California Publications, Bulletin of the Department of Geological Sciences, v. 25, no. 7, p. 347-422.

Christiansen, R. L., 1979, Cooling units and composite sheets in relation to caldera structure: Geological Society of America Special Paper 180.

Dalrymple, G. B., and Mankinen, E. A., 1979, Revised geomagnetic polarity time scale for the interval 0-5 m.y. B. P.: Journal of Geophysical Research, v. 84, p. $615-626$.

Bichelberger, J. C., 1975, Origin of andesite and dacite: evidence of mixing at Glass Mountain in California and at other circum-Pacific volcanoes: Geological Society of America Bulletin, v. 86, p. 1381-1391.

Heiken, G., 1978, Plinian-type eruptions in the Medicine Lake Highland, California, and the nature of the underlying magma: Journal of Volcanology and Geothermal Research, v. 4, p. 375-402.

Hower, J., 1959, Matrix corrections in the x-ray spectrographic trace element analysis of rocks and minerals: American Mineralogist, v. 44, p. 19-32.
Lipman, P. W. Christiansen, R. L., and $0^{\prime}$ Connor, J. T., 1966, A compositionally zoned ash-flow sheet in Southern Nevada: U.S. Geological Survey Professional Paper 524-F, 47 p.

Macdonald, G. A., 1972, Volcanoes, Prentice-Hall, New Jersey, $510 \mathrm{p}$.

Mertzman, S. A., 1977, The petrology and geochemistry of the Medicine Lake volcano, California:

Contributions to Mineralogy and Petrology, v. 62, p. 221-247.

Mertzman, S. A., in press, The petrogenesis of Recent silicic magmatism in the Medicine Lake Highland: evidence from cognate inclusions found at Little Glass Mountain, California: Geochimica et Cosmochimica Acta.

Noble, D. C., 1979, Speculations on the origin of the Medicine Lake caldera: Oregon Department of Geology and Mineral Industries Bulletin 65, p. 193.

Ratte, J. C., and Steven T. A., 1967, Ash flows and related volcanic rocks associated with the Creede caldera, San Juan Mountains, Colorado: U. S. Geological Survey Professional Paper, 524-H, 58 p.

Walter, R. C., 1975, Geology and petrology of the northwest portion of the Medicine Lake Highland, California: Unpub. B. A. thesis, Franklin and Marshall College.

Williams, H. and McBirney, A. R., 1979, Volcanology: Freeman, Cooper and Co., San Francisco, 397 p. 
Jon H. Fink

Geology Department, Stanford University, Stanford, CA 94305

(Present address: Department of Geology, Arizona State University, Tempe, Arizona 85281)

The purpose of these two stops is to observe and interpret the structural relations exposed at the surface of a very young rhyolitic obsidian flow. Before surface structures can be discussed however, the flow stratigraphy and the original attitudes of foliations must be determined. Unfortunately these Holocene obsidian flows do not have any well exposed cross sections so we are limited to observations of flow fronts and to comparisons with older, more dissected flows. At these stops we will first define the stratigraphy and discuss the attitudes of foliations as seen in flow fronts; then we will go onto the upper flow surface and see the variety of structural relations exposed there.

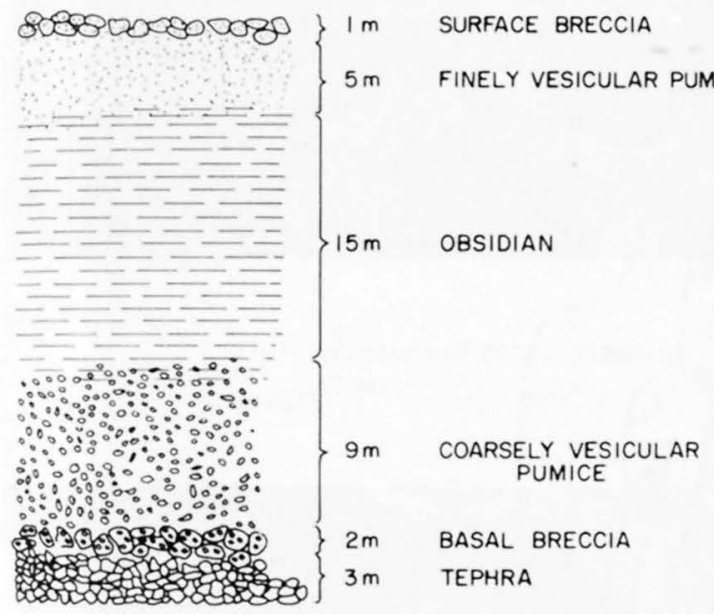

Figure 1. Schematic cross section through a $35 \mathrm{~m}$ thick rhyolitic obsidian flow based on observations of Little Glass Mountain and dissected flows in New Mexico and Lipari, Italy.

Stop \#1 - Northeast lobe, Little Glass Mountain

Before we can interpret the deformed flow structure we must be able to recognize the undeformed structure. This stop offers an opportunity to observe the different units which make up the flow
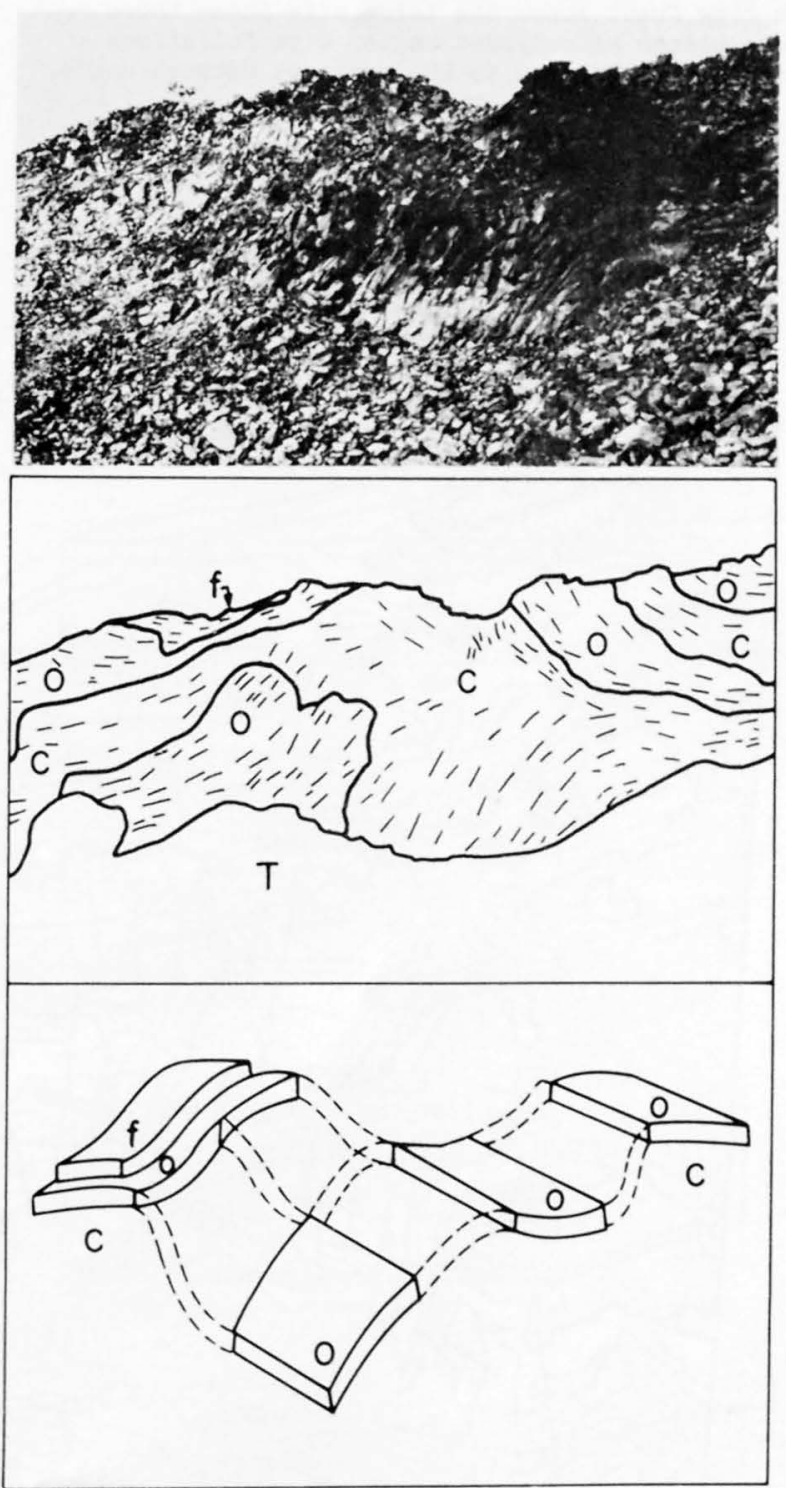

Figure 2. Flow front, Little Glass Mountain. Photo; foliations; interpretation. Complexly folded coarsely vesicular pumice (c) overlain by obsidian ( 0 ) and finely vesicular pumice (f). Base obscured by talus ( $\mathrm{T}$ ). 
stratigraphy. First we note the layer of tephra which covers the ground surrounding the flow. Isopach maps indicate that the source of this tephra is under Little Glass Mountain (Heiken, 1978).

If we look at blocks within the talus pile we can distinguish 3 principal types based on color and vesicularity: black glassy obsidian, brown to greenish grey coarsely vesicular pumice, and whitish grey finely vesicular pumice. These three rock types have uniform chemical composition $\left(73 \% \mathrm{SiO}_{2}\right)$ and all exhibit flow layering, but they differ in density, with the obsidian having the highest. In the flow front above the talus pile these three rock types appear as coherent units, with foliations generally conforming to the contacts between units.
Both in the flow fronts and on the upper flow surface the coarsely and finely vesicular pumice units are nearly always separated by obsidian; they do not appear in conformable contact. Furthermore, the coarse pumice nearly always underlies the obsidian, so that the apparent stratigraphic sequen is (upward): tephra, coarsely vesicular pumice, obsidian, finely vesicular pumice. Above the tephra and on top of the flow are breccias comprised of blocks of the other three flow units (Figure 1).

In older more dissected rhyolite and rhyolitic obsidian flows, foliations near the base are generally horizontal whereas those near the top are more nearly vertical. The depth of the transition from vertical to horizontal flow-layering varies fron

$\underbrace{0 \quad 25 \quad 50 m}$

Talus

Coarsely vesicular pumice

Obsidian

Finely vesicular pumice

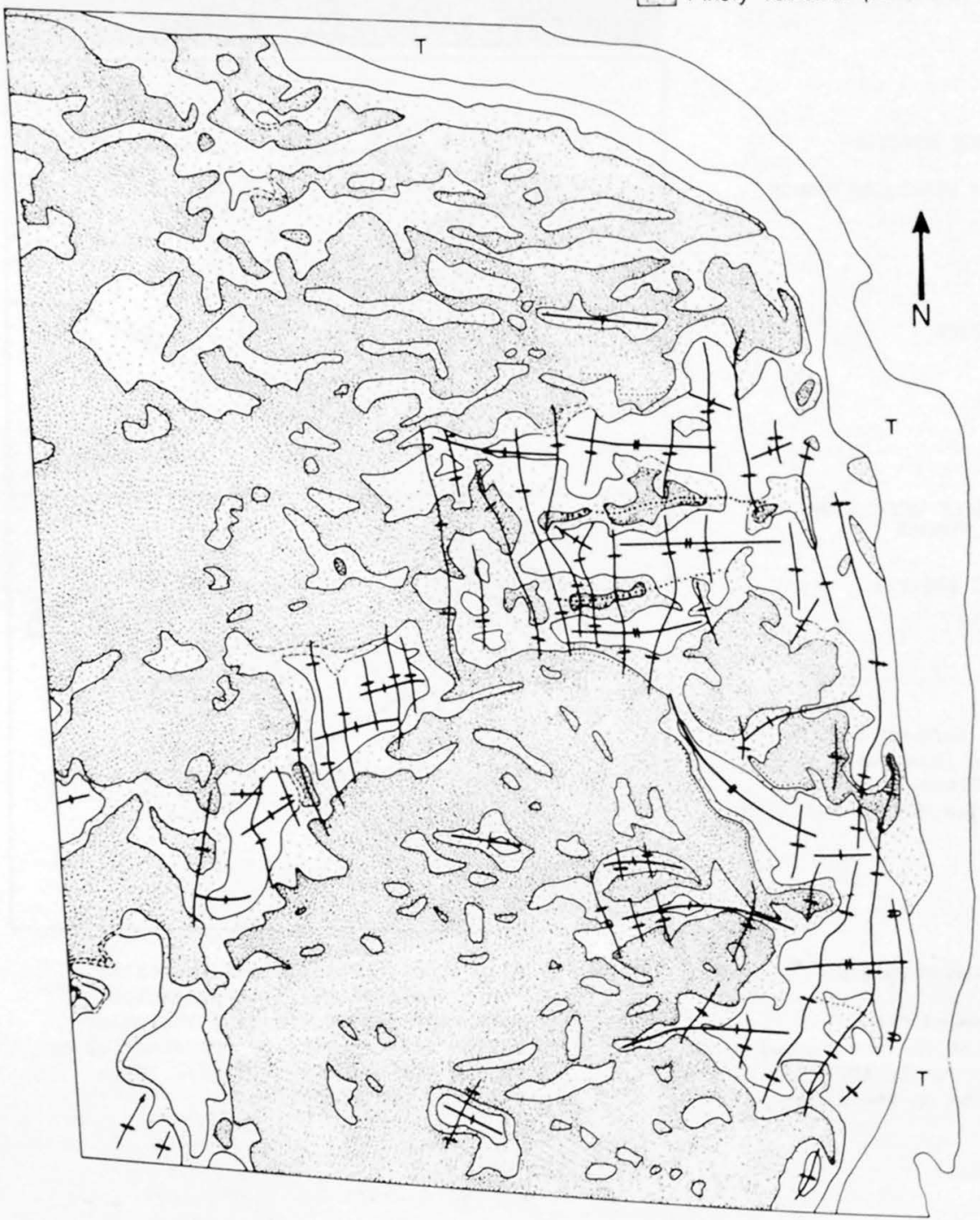

Figure 3 .

Map of part of northeast lobe, Little Glass Mountain. Compressional fold axes marked by 1 ines with arrows; axes of fractures marked by lines with one or two cross bars (two bars indicates separations across fracture of more than $5 \mathrm{~m}$ ). Dotted lines indicate margins of fracture surfaces. 
flow to flow and within a given flow, however it generally lies within the top 25\% of the flow. Thus within the stratigraphy seen in Little Glass Mountain the contact between the coarse pumice and obsidian layers may be considered to be originally horizontal. Mapping the orientations of this contact on the flow surface indicates the deformation. Figure 2 shows the three units exposed in a fold within the flow front. This fold and others like it

Figure 4. Compressional folds in flow front, northwest lobe, Little Glass Mountain:

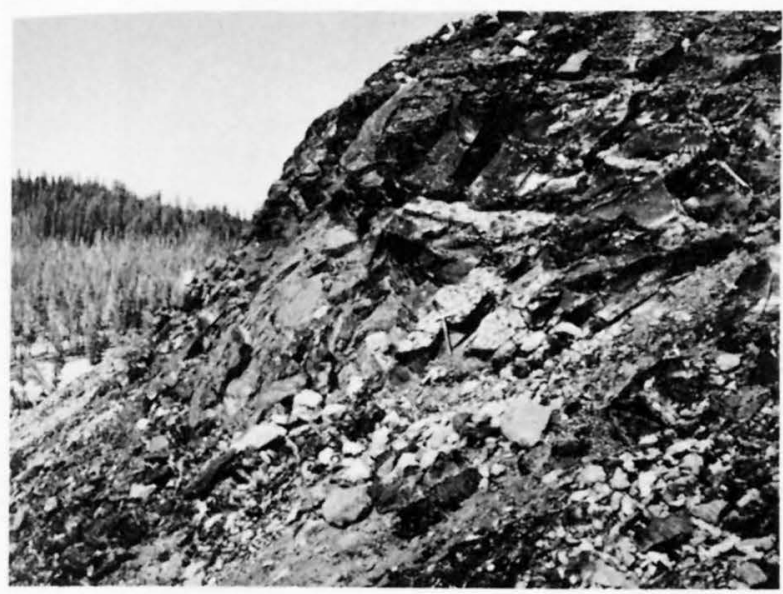

a) overturned fold, plunging into flow.

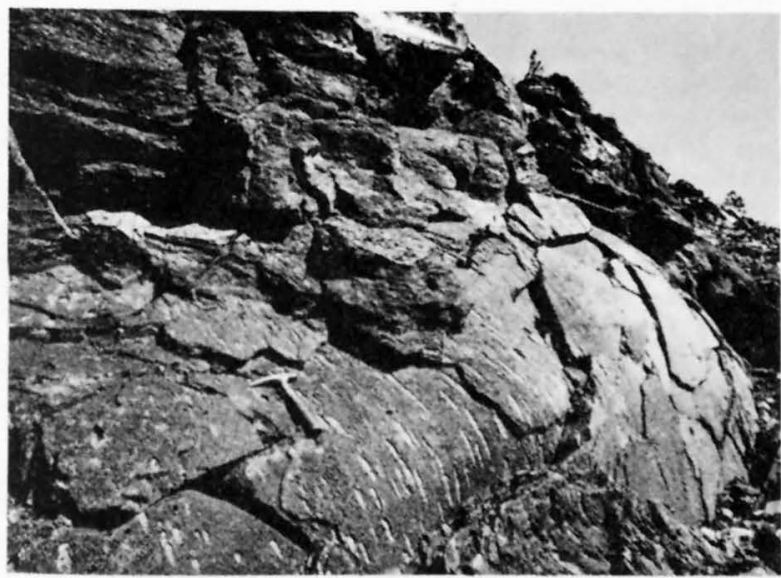

b) closer view of same fold. Stretched vesicles show extension direction associated with folding. are also exposed on the upper flow surface.

About $20 \mathrm{~m}$ south of this fold is an anticline of coarse pumice which appears to be dissected by a valley 3-4 m deep. Later we will see that these valleys which trend perpendicular to the flow front are fractures which commonly bisect anticlines cored by coarse pumice. If we climb onto the flow through this fracture and climb the northern wall, we will be able to see much of the area covered by the map in Figure 3.
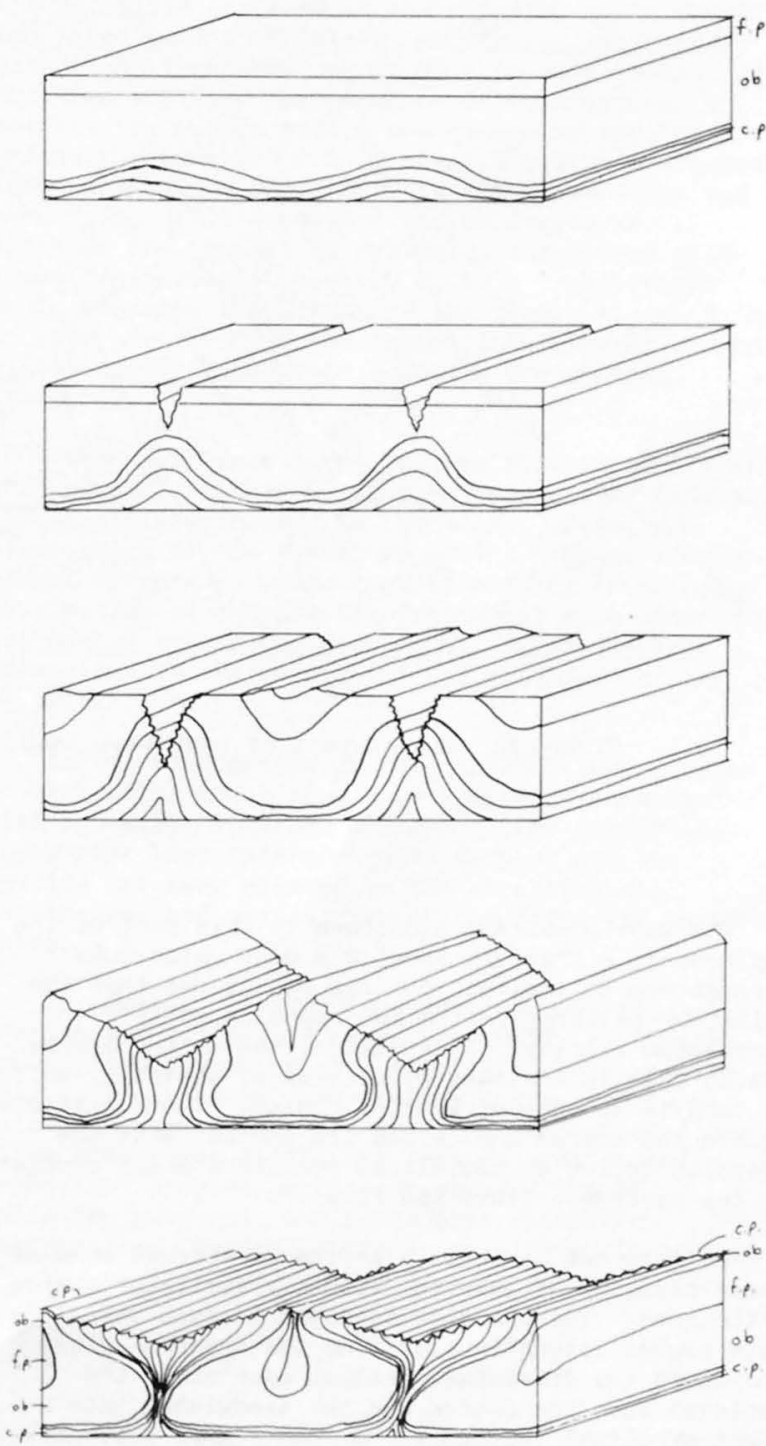

Figure 5. Diapir rise accompanied by fracture of surface. Notice that fracture axis corresponds to earlier anticlinal axis and that fine pumice between the diapirs forms tight synclines. 


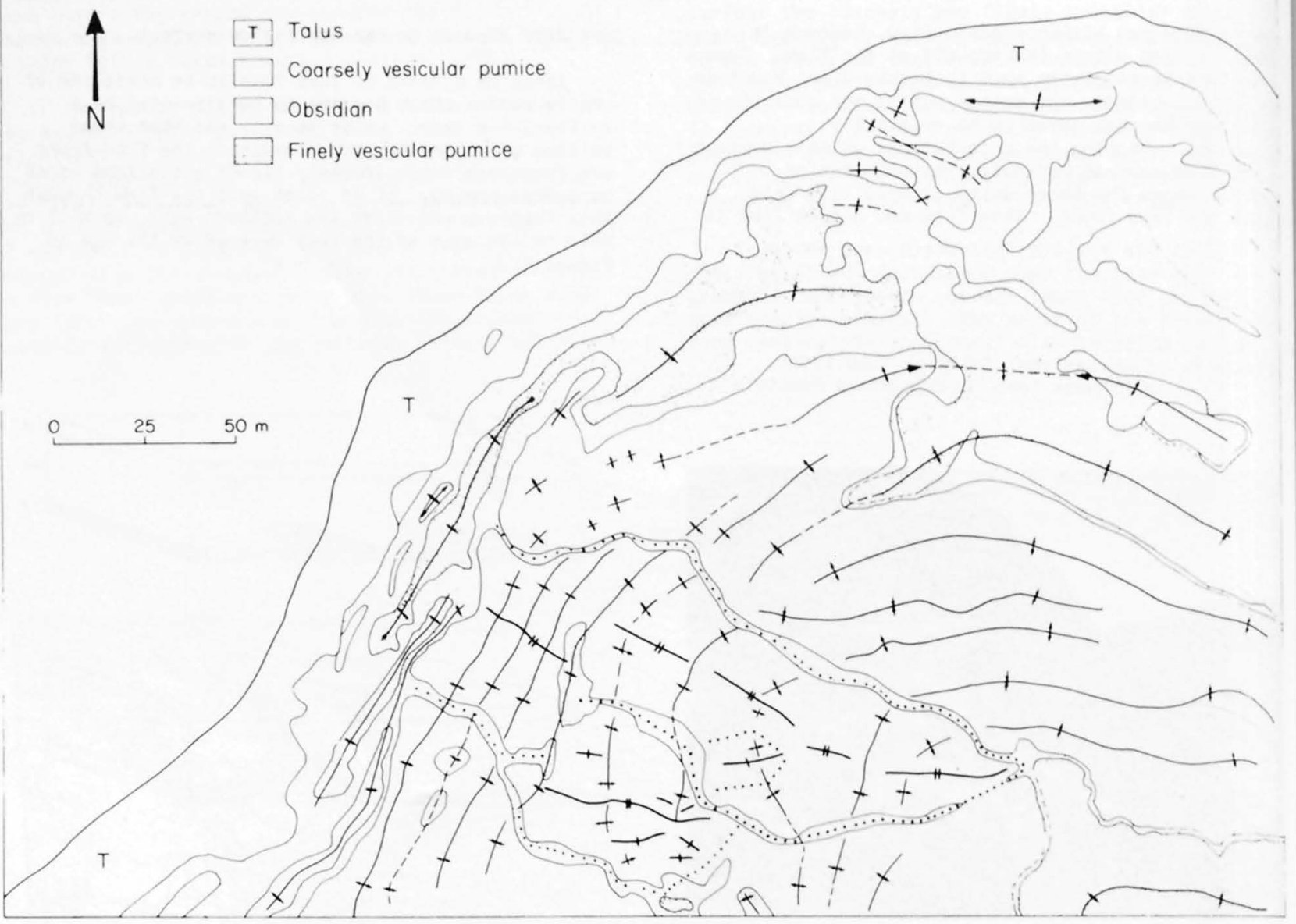

Figure 6. Map of part of northwest lobe, Little Glass Mountain. Symbols same as Fig. 3.

The most prominent structure in this part of the map area is a fracture about $2 \mathrm{~m}$ deep which cuts through coarse pumice. One can easily see that the foliation patterns in the two opposing walls correspond exactly. In addition, the entire coarse pumice area is enclosed by an area of obsidian, which in turn is surrounded by fine pumice. The foliations within the coarse pumice and its contact with the obsidian define an anticlinal structure which plunges to the northwest (into the flow).

$20 \mathrm{~m}$ to the north is a series of several more of these plunging, fractured, coarsely vesicular pumice anticlines. The obsidian adjacent to each anticline gets pushed laterally away from the fracture plane, and where two fractures parallel each other the obsidian and fine pumice may get sandwiched into a tight synclinal configuration. In Figure 3 , these synclinal axes parallel to the fractures are marked by heavy dots. Notice that the separation or spreading across each fracture increases toward the flow front, suggesting that these fractures form, at least in part, in response to circumferential spreading near the front of an advancing flow lobe.
The coarsely vesicular pumice bordering each of the fractures is folded, with fold axes perpendicular to the fracture axes. This creates a pattern of coarse pumice domes. In figure 3 , the fold axes are indicated by heavy lines with arrows, whereas the fracture axes are marked by cross bars. These folds generally lie perpendicular to the flow direction and are interpreted to be surface folds caused by compression, similar to the ropes on pahoehoe basalt flows (Fink and Fletcher, 1978).

The basal position and relatively low density of the coarsely vesicular pumice form the basis for gravity instability within the flow structure. The instability can give rise to regularly spaced diapirs of coarse pumice. On aerial photographs of both Big and Little Glass Mountains, such regularly spaced areas can be clearly seen. Depending on their position relative to the flow front these areas of coarse pumice may be subjected to subsequent folding or fracturing or both, resulting in the complex structural pattern observed on this portion of Little Glass Mountain. 


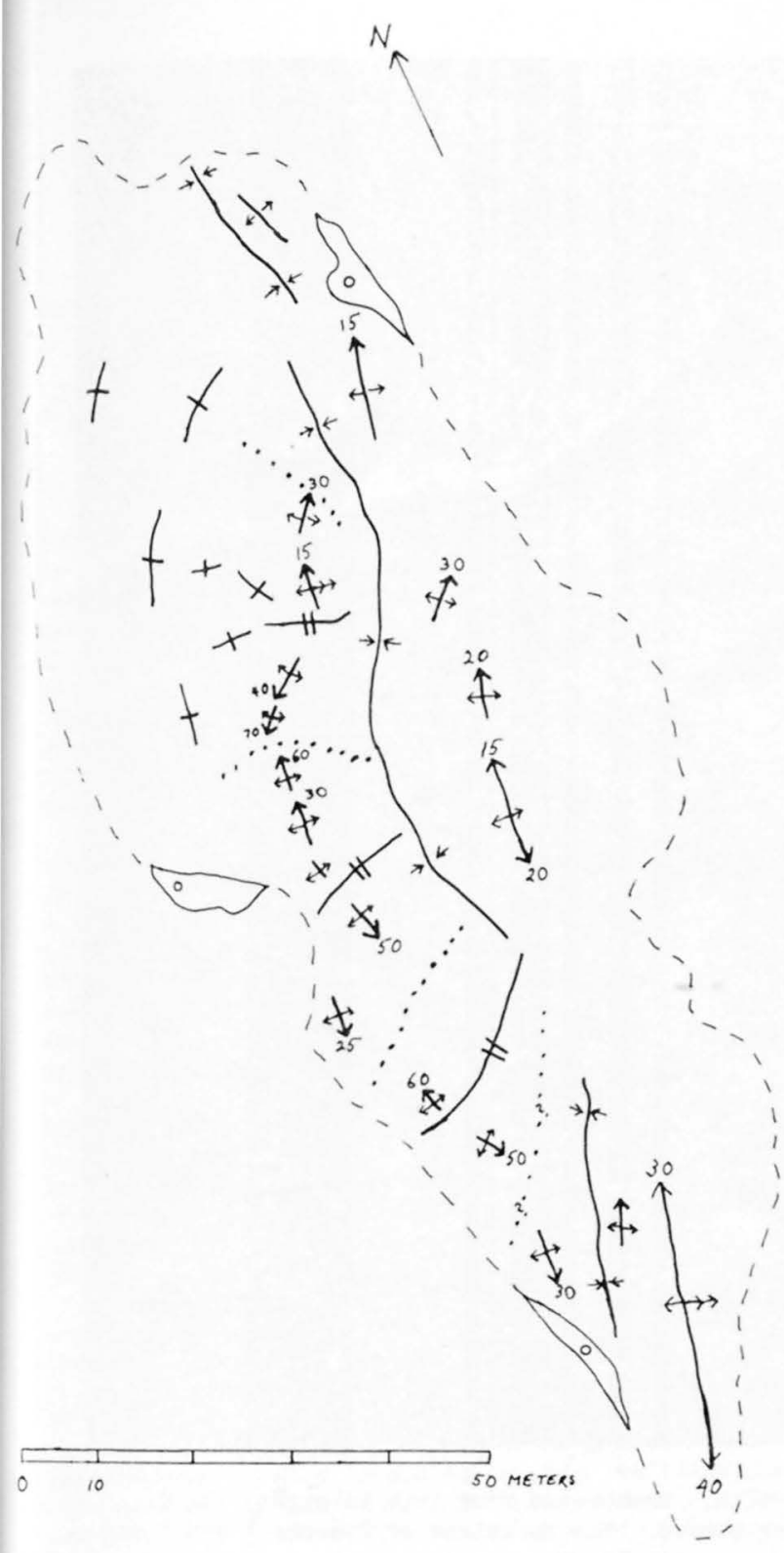

Figure 7. Map of large ridge adjacent to fractured area on northwest lobe.
The first structure is located about $2 / 3$ up the flow front, $20 \mathrm{~m}$ south of the small parking area. Here coarse pumice and obsidian with very large vesicles (over $10 \mathrm{~cm}$ in diameter) form an overturned fold, whose axial plane plunges into the flow (Figure 4). Stretching of vesicles indicates the extension direction associated with folding. Mineralization of the vesicles occurred prior to this folding as the coatings are also stretched. Within this fold the obsidian drapes over the coarse pumice, and higher up in the front the obsidian forms a syncline cored by finely vesicular pumice. These folds with axes parallel to the flow front continue on the upper flow surface.

Climbing to any high point on the upper surface one can see several 3-5 m deep fractures trending normal to the flow front. Here again, examination of the foliation patterns in the opposing walls shows the large amount of lateral separation associated with these fractures, up to $40 \mathrm{~m}$ in some cases. The obsidian and fine pumice which stratigraphically overlie the coarse pumice are generally upturned around the margins of this area, but within the area they have been sandwiched into tight synclines and even "subducted" between adjacent fractures. Although the cumulative extension associated with these fractures is over $100 \mathrm{~m}$, this "subduction" could conserve the volume of the flow. Figure 5 is an interpretation of the interaction between upward rising coarse pumice and downward propagating fractures.

Folds with axes normal to the flow direction can also be seen in this area, and these extend laterally into the higher ridges to the south. Detailed examination of the structure of the highest of these ridges (Figure 7) shows that it also is interrupted by a series of subparallel fractures, with separation increasing toward the flow front, again due to extension associated with radial expansion of the flow.

Aerial photographs of this lobe (Figure 8) show several other areas of coarse pumice and obsidian with irregular spacings along the flow direction. These have been interpreted as diapirs and the spacing has been related to the stratigraphic thicknesses and viscosities of the different textural units.

In summary, Little Glass Mountain, being nearly erosion-free, offers a rare opportunity to observe the surface structure of a rhyolitic obsidian flow just as it appeared upon cooling. The structural relations seen here could only be detected on older flows with great difficulty because erosion and vegetation prevent continuous examination of foliation patterns, and subsequent alteration obscures the textural differences originally present.

\section{References}

Fink, J. H., 1978, Surface structures on obsidian flows: PhD thesis, Stanford University, $175 \mathrm{p}$.

Fink, J. H., Gravity instability in the Little Glass Mountain rhyolitic obsidian flow, northern California: Tectonophysics, in press. 


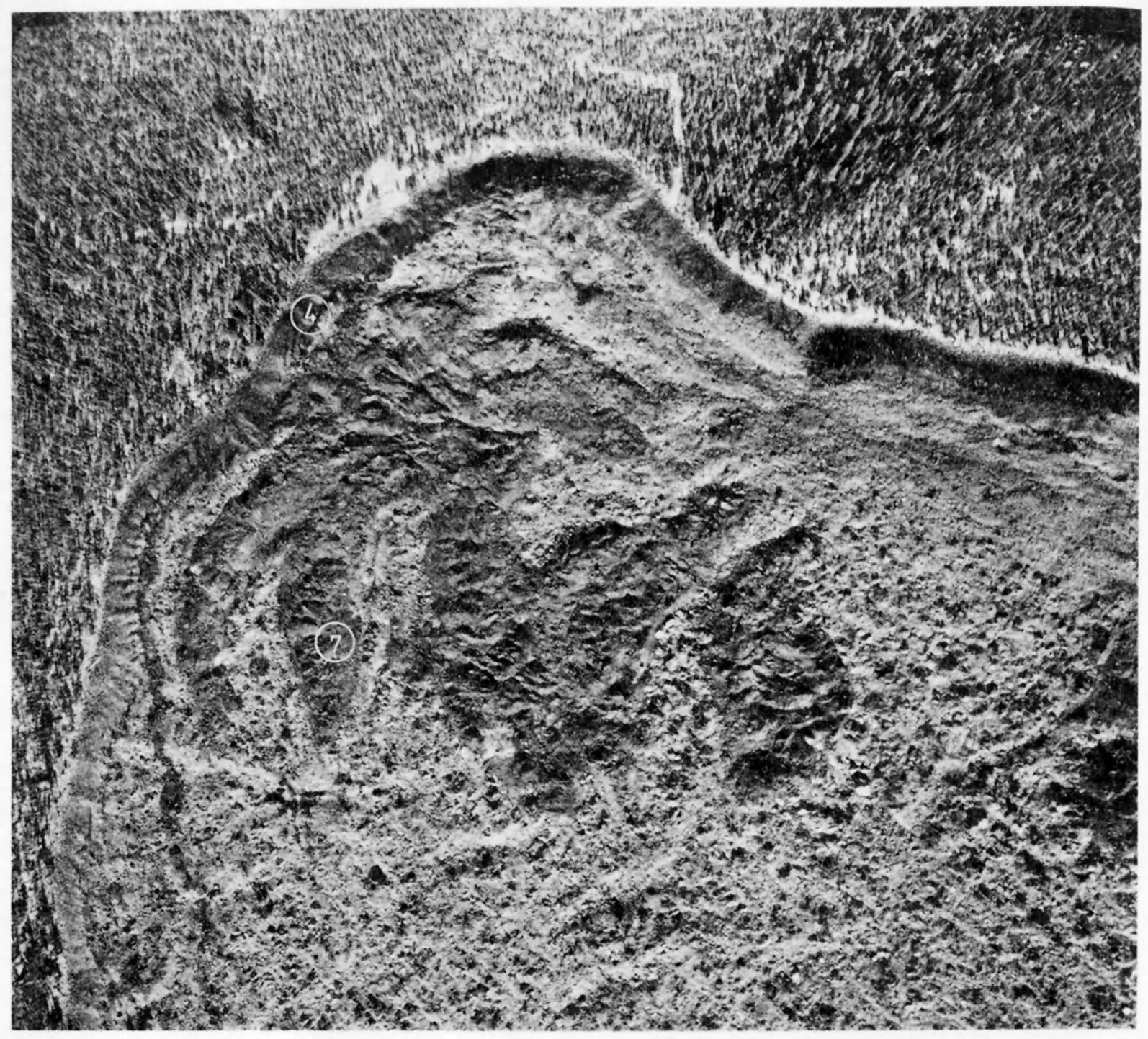

Figure 8. Photo, part of northwest lobe, Little Glass Mountain. Lava moved from left to right. Dark fractured areas are primarily coarsely vesicular pumice. The locations of Figures 4 and 7 are indicated.

Fink, J. H., Surface folding on rhyolite flows: Geology, in press.

Fink, J. H., and Fletcher, 1978, Ropy Pahoehoe: Surface folding of a viscous fluid: Journal of Volcanology and Geothermal Research, v. 4, p. 151-170.

Heiken, G. 1978, Plinian type eruptions in the Medicine Lake Highland, California and the nature of the underlying magma: Journal of Volcanology and Geothermal Research, v. 4, p. 375-402. 
HOLOCENE PLINIAN TEPHRA DEPOSITS OF THE MEDICINE LAKE HIGHLAND, CALIFORNIA

Grant Heiken

Los Alamos Scientific Laboratory, Geosciences Division, Los Alamos, New Mexico 87545

condensed from: PLINIAN-TYPE ERUPTIONS IN THE MEDICINE LAKE HIGHLAND, CALIFORNIA, AND THE NATURE OF THE UNDERLYING MAGMA, Jour. Volc. and Geotherm. Res., 4. 375-402 (1978).

- Elsevier Sci. Pub. Co., Amsterdam

\section{INTRODUCTION}

The Medicine Lake Highland is a young volcano located $55 \mathrm{~km}$ east of Mount Shasta, on the western margin of the Modoc Plateau. The volcano is east of the north-south-trending chain of High Cascade volcanoes and within a $100-\mathrm{km}$ diameter depression filled with volcanic rocks of $\mathrm{Pliocene}$ to Holocene age. It overlies a plateau consisting of late Tertiary tuffs, lava flows and sediments, cut by north- to northwest-trending normal faults (Powers, 1932; Anderson, 1941). The volcanic center is located at the intersection of several of these fault systems.

The highland is a $1 \mathrm{~km}$ thick, $25 \mathrm{~km}-d i a m e t e r$ shield, composed of andesitic and basaltic flows (Anderson, 1941). There is an $8 \mathrm{~km}$ by $6 \mathrm{~km}, 100-200$ m deep caldera at the shield summit. Noble (1969) believes that an andesitic pyroclastic flow, interbedded with andesitic flows of the shield, may have been associated with caldera collapse. Andesitic, dacitic and rhyolitic flows were erupted along the caldera rim and partly bury the walls. Construction of the shield and caldera formation are believed to have occurred mainly during Pliocene to Pleistocene time (Anderson, 1941). During the time elapsed between the earlier eruptions of andesite, dacite and rhyolite and more recent activity, there was glaciation of the highland and substantial soil developed (Anderson, 1941).

Holocene activity was bimodal, consisting of basaltic volcanism, mainly on the shield flanks and eruption of tephra and lavas of intermediate to rhyolitic composition within and close to the rim of the caldera.

The purpose of this paper is to present data on the Holocene pumice deposits of the Medicine Lake Highland and to speculate on their origin. These deposits were erupted from Glass Mountain, a flow of rhyolite-dacite on the northeast rim of the caldera and from Little Glass Mountain, located a few kilometers west of the caldera (Fig. 1).

\section{Age of the Holocene deposits}

Underlying Holocene rhyolitic and basaltic tephra exposed in the highland is a red or yellow soil, developed on both flows and older tephra. This soil is estimated to be more than 15,000 years old (D. Miller, personal communication, 1977). The oldest tephra overlying the soil are fine-grained basaltic ash layers near Little Glass Mountain and northwest of Glass Mountain. They range from 0.5 to $14 \mathrm{~cm}$ thick and are reasonably fresh (sideromelane glass is well preserved). It is possible that these tephra are from Paint Pot Crater or some of the younger

*The ${ }^{14} \mathrm{C}$ measurements were made by Isotopes, Inc. and the sample was collected by C. D. Miller from the northwest slope of Little Mt. Hoffman (Fig. 1). The sample consists of wood, leaves, bark and cones. cones in Lava Beds National Monument (Table 1). Immediately north of Glass Mountain, the soil has developed on an older pumice bed (Chesterman, 1955). Chesterman dated trees that were growing in this soil and buried by younger pumice beds to indicate the age of the Holocene Glass Mountain tephra. Overlying the lowest Holocene basaltic tephra unit are the pumice deposits of Little Glass Mountain, with a radiocarbon date of $1065 \pm 90$ years*. As will be discussed later, the tephra are similar to those of Glass Mountain. Luckily, one of the more extensive tephra beds from Little Glass Mountain has a distinctive yellow hue. By following this bed it was determined that Little Glass Mountain tephra underlie tephra units erupted from Glass Mountain. The age of the Little Glass Mountain flow is not known, but is believed to be only slightly younger than its tephra deposits; they may have been part of the same eruptive sequence.

Within the zone of overlapping Glass Mountain and Little Glass Mountain tephra, there is a thin $(5 \mathrm{~cm}$ ) bed of basaltic ash, believed to be from one of the young cinder cones on the northwest flank of the shield.

The uppermost tephra beds in the highland were erupted from Glass Mountain and have a radiocarbon age of $1360 \pm 240$ years (Chesterman, 1955). The analyses were of carbon from tree trunks buried by the Glass Mountain pumice falls. The Glass Mountain flows have been dated at 130 to $390+240$ years by the "C method (Friedman, 1968); these dates were based on wood from standing trees damaged by the flow. There is an inconsistency here: field evidence indicates that little time elapsed between the pumice eruptions and extrusion of the flows at Glass Mountain, whereas radiocarbon dates indicate a hiatus of 1000 years. The older date of $1360 \pm 240$ years is of tephra overlying tephra dated at $10 \overline{65}+90$ years. Tephra from Glass Mountain also overlie the very well-preserved High Hole Crater cinder cone and Burnt Lava Flow. The youth of these basaltic vents is also indicated by the presence of tree trunks burned by the flows, resting on the flow margins.

In summary, most Holocene silicic rocks near the highland summit and the most youthful basaltic cones and flows on the highland flanks were contemporary and may have erupted during the last 1100 years.

\section{RHYOLITIC TEPHRA FROM THE HOLOCENE ACTIVITY}

\section{Little Glass Mountain}

Tephra from Little Glass Mountain form a highly elongate ellipse with its long axis oriented southwest-northeast (Fig. 2). Measurable tephra layers are present up to a distance of $25 \mathrm{~km}$ and individual rhyolitic lapilli possibly from Little Glass Mountain have been found $50 \mathrm{~km}$ west-southwest of the vent. (The most distant lapilli were found by D. Miller on the slopes of Mt. Shasta). The area 


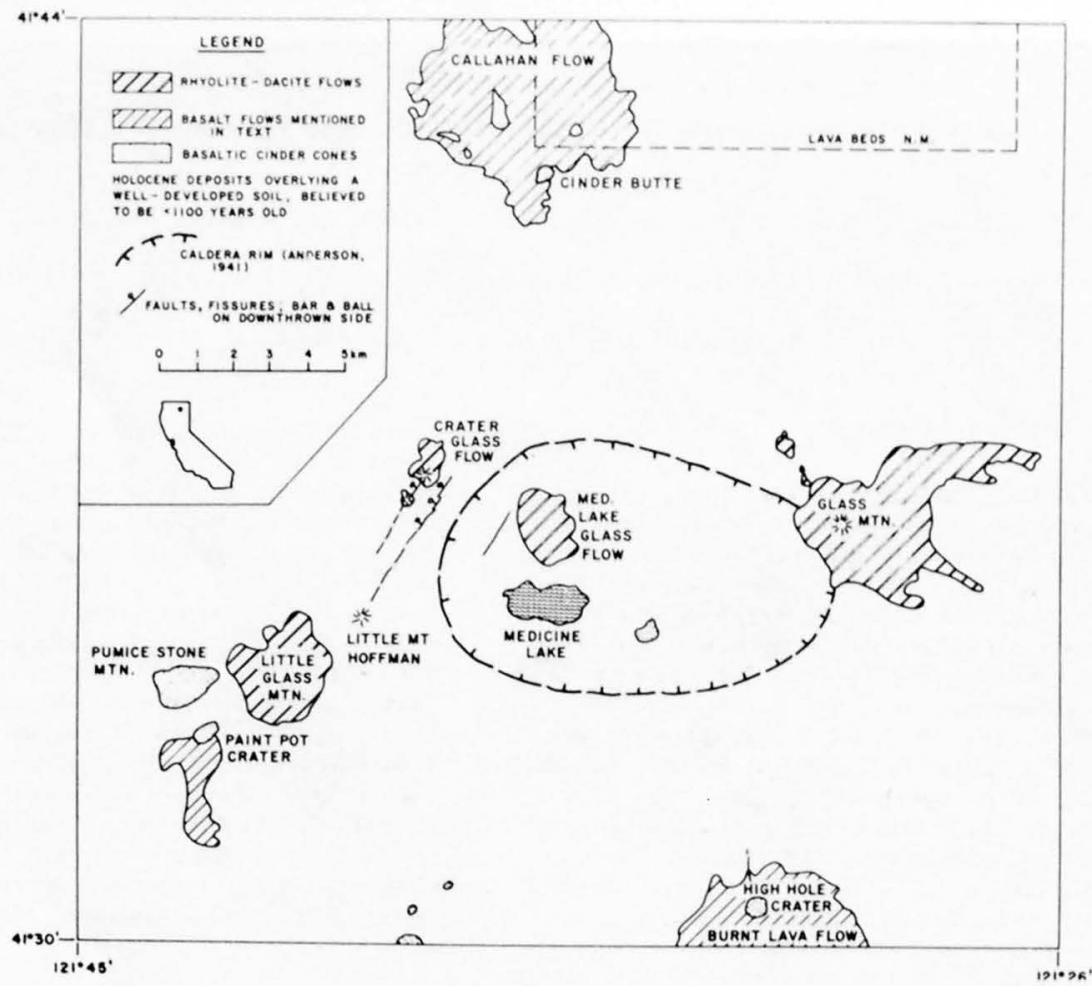

Fig. 1. Distribution of Holocene deposits believed to be $<1100$ years old in the Medicine Lake Highland. The fissures near Crater Glass Flow are open and well preserved. Based on U.S.G.S. 15' topographic quadrangle (Medicine Lake and Timber Mountain, California), the geologic map of Anderson (1941) and field work by the author.

TABLE

Age relations of Holocene volcanic deposits in the Medicine Lake Highland

\begin{tabular}{|c|c|}
\hline Rhyolitic & Basaltic \\
\hline \multirow{3}{*}{$\begin{array}{l}\text { Glass Mountain flows; "C dates } \\
\text { by M. Rubin in: Friednan, } 1968 \text { ) } \\
\text { of } 390,380,190 \text { and } 130 \text {, dil }= \\
240 \text { years. } \\
\text { Tephra of Glass Mountain, } C \text { date } \\
\text { (by } w \text {. F. Libby in: Chesterman, } \\
1955 \text { ) of } 1360=240 \text { and } 1107= \\
380 \text { years. }\end{array}$} & \\
\hline & \\
\hline & $\begin{array}{l}\text { Burnt Lava Flow and High Hole Crater, a } \\
\text { well-preserved cinder cone. } \\
\text { Well-preserved basaltic ash, thickening } \\
\text { toward well-preserved cinder cones on } \\
\text { the north slopes of the Medicine Lake } \\
\text { shield. }\end{array}$ \\
\hline \multirow{2}{*}{\multicolumn{2}{|c|}{ 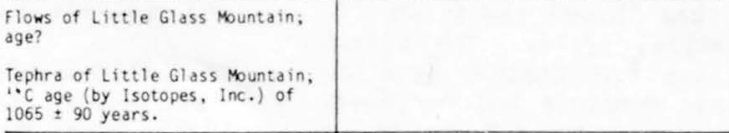 }} \\
\hline & \\
\hline . & $\begin{array}{l}\text { Well-preserved basaltic ash, source in } \\
\text { Lava Beds, N.M.; exact vent not known. } \\
\text { Well-preserved basaltic tephra of Paint } \\
\text { Pot Crater, overlain by tittle Glass } \\
\text { Mountain tephra. }\end{array}$ \\
\hline
\end{tabular}

So:1 developed on andesite flows and cinders (Late Wisconsin or early Tioga; D. Miller, personal comunication, 1977) $10,000-15,000$ years 


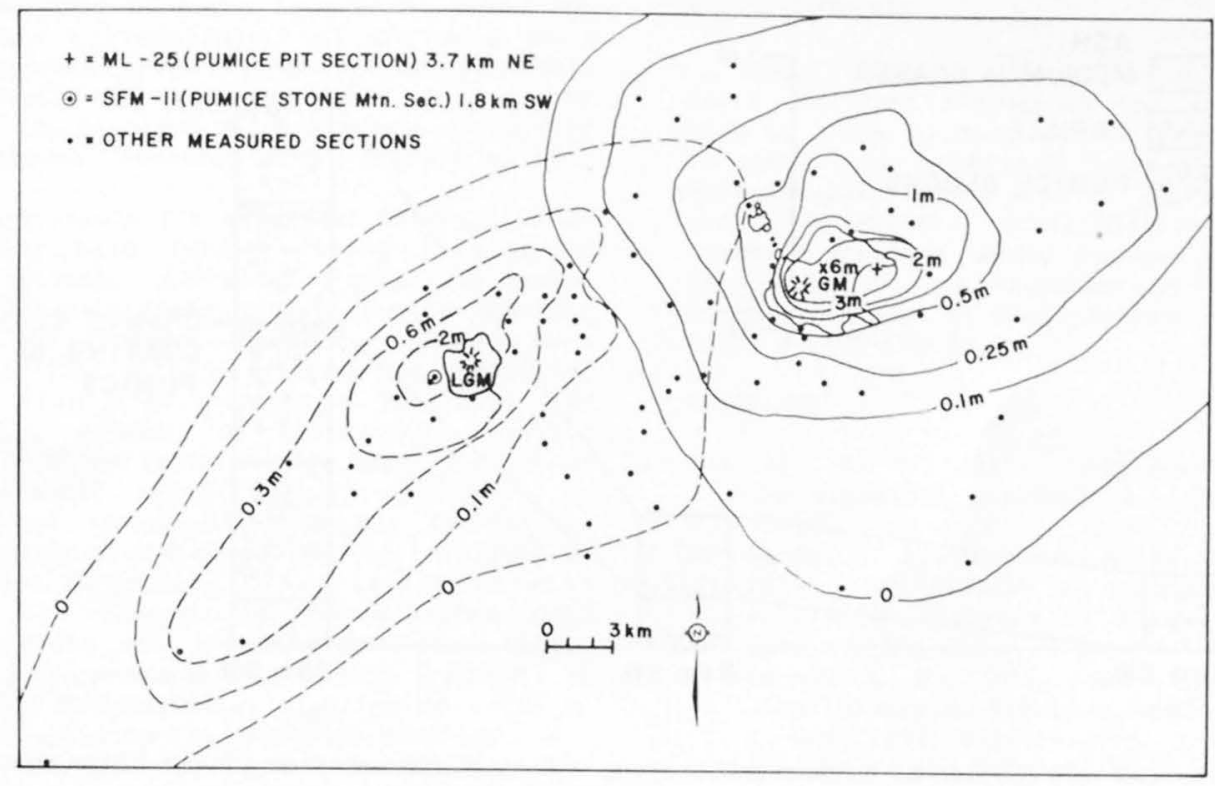

Fig. 2. Isopach map of Little Glass Mountain (dashed) and Glass Mountain (solid) tephra. Stippled areas are flows at the two vent areas. Dots are the locations of measured stratigraphic sections. The cross near Glass Mountain is the location of the thickest section measured.

covered by measurable tephra layers is about $200 \mathrm{~km}^{2}$. the tephra have a volume of $0.046 \mathrm{~km}^{3}$.

Within $3 \mathrm{~km}$ southwest of Little Glass Mountain, there are five tephra units, consisting of mainly reversely graded, pale gray pumice and lapilli-size blocks in coarse gray ash.

These units range in thickness from 20 to $50 \mathrm{~cm}$ and each contains between 5 and $20 \%$ lithic fragments. The only evidence for a hiatus within these units is a thin $(1-5 \mathrm{~cm})$ coating of orange-brown clay at the surface of the third tephra unit. Contacts between all other units exhibit no evidence of weathering or erosion. Between 3 and $8 \mathrm{~km}$ southwest and $6 \mathrm{~km}$ northeast of Little Glass Mountain, there are two tephra units; the lowest, overlying a well-developed soil, consists of a $0-24 \mathrm{~cm}$ thick, medium to coarse gray ash sometimes with a slight yellow hue; the upper unit consists of a 13-64 cm thick, generally reversely graded, lapilli-bearing coarse ash. It is possible that the break between units 3 and 4 , near the vent corresponds to the break between the two tephra units farther from the vent. Beyond $9 \mathrm{~km}$, only one tephra layer is present. This tephra bed is most readily correlated to the upper of the two tephra units, located closer to Little Glass Mountain, on the basis of its greater thickness (Fig. 3). All of the tephra units erupted from Little Glass Mountain appear to have been deposited as air-fall.

There appear to have been two periods of explosive activity at Little Glass Mountain; the only evidence for this, however, is the clay coating developed on the top of a tephra layer (Fig. 3). The tephra are overlain by the flows of Little Glass Mountain, a rhyolite flow with a volume of $0.3 \mathrm{~km}^{3}$. The flow has buried the vent area.

\section{Glass Mountain}

Pumice deposits from Glass Mountain form an irregular ellipse, with the long axis trending east-northeast (Fig. 2); the deposits with measurable thicknesses cover an area of $320 \mathrm{~km}^{2}$ and have a volume of $0.09 \mathrm{~km}^{3}$. Within an approximate range of $3 \mathrm{~km}$ east and northeast of the summit of Glass Mountain, there are multiple tephra beds. Within a pumice pit located $2.8 \mathrm{~km}$ east of the summit, eleven tephra beds, with a combined thickness of $3.7 \mathrm{~m}$, overlie a red-brown soil developed on cinders. The tephra units consist of reversely graded or massive pumice block and lapilli-bearing coarse gray ash, 5-102 cm thick. Several of the uppermost beds contain 10-30\% lapilli and coarse ash-size lithic fragments (mainly angular obsidian fragments and cinders). Sharp depositional contacts exist between these beds; there was no erosion or weathering at the bedding plane surfaces. Several tephra units exhibit a pale orangepink discoloration near the top of each bed; the alteration may be due to mild vapor-phase activity that left a thin film of hematite stain on pyroclast surfaces. Between a distance from the vent of 3-11 $\mathrm{km}$ east, 3-11 km north and 1(?) - $3 \mathrm{~km}$ south and west, there are two or three tephra beds with combined thicknesses of 22-131 cm. Both consist of reversely graded or massive beds of gray medium-ash to lapilli-size tephra. Due to the remarkable uniformity of the Glass Mountain tephra, it was not possible to corelate any of these beds with units described near the vent. Units 1, 7 and 11 of the Pumice Pit section are only tentatively correlated with the more distant units, because they are the thickest units. Beyond the range of multiple beds there is only one bed of massive coarse ash and lapilli; this rapidly thins to zero.

All tephra beds from Glass Mountain drape the underlying terrain and exhibit no current structures; there is no evidence for deposition by flow. After deposition of rhyolite tephra, the Glass Mountain dacite-rhyolite flows were erupted along a northnorthwest-trending fissure. In addition to the main body of Glass Mountain there are, along the fissure, nine small domes. Associated with the domes are 


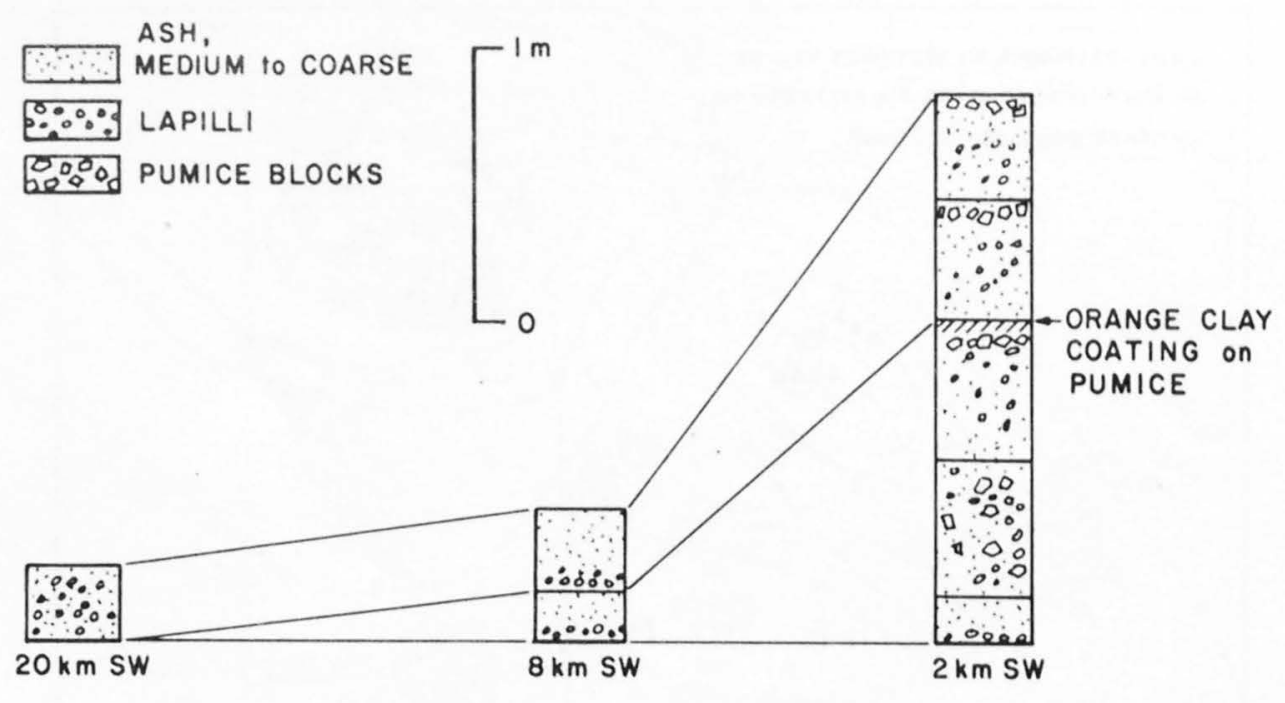

Fig. 3. Tentative correlation of tephra units along a line southwest from Little Glass Mountain. There may have been two episodes of explosive activity at Little Glass Mountain.

small, crescent-shaped pumice cones, consisting of angular, 2-45 cm long pumice lapilli and blocks.

\begin{abstract}
Other silicic vents
The Crater glass and Medicine Lake glass flows appear to be approximately the same age as Glass Mountain and Little Glass Mountain, but neither exhibited much explosive activity. There were only a few lapilli or blocks erupted from these vents; there is no evidence for extensive tephra deposits associated with them.
\end{abstract}

\section{DISCUSSION}

Vents for the Holocene eruptions of silicic tephra and lavas are located along the oval caldera rim and along fissures parallel to the rim. Glass Mountain and associated small domes were erupted along a fissure trending northwest-southeast. There is no clear evidence that Little Glass Mountain was erupted from a fissure. There is, however, an arcuate trend, concentric to the caldera rim that includes the Crater Glass Flow (Fig. 1) and several en-echelon open fissures. The fissures, with a total length of several kilometers, do not appear to be associated with any of the normal faults of the region and are believed to be an expression of rhyolite dikes that are near the surface, but did not erupt. Crater Glass Flow was erupted from a segment of one of these fissures.

It was suggested by Anderson (1941) that the caldera at Medicine Lake collapsed along cone fractures that later acted as conduits for Pleistocene and Holocene silicic magma. This may indeed be the case; eruptions along the caldera rim and along fissures concentric to that rim may indicate the presence of several concentric, inward dipping cone sheets located near the summit of the Medicine Lake shield. Cone fracture systems are developed over plutons during intrusion and have been observed in many intrusive-volcanic complexes throughout the world (Anderson, 1937; Koide and Bhattacharji, 1976). Cone fractures dip inward, from the ground surface, at angles of $45^{\circ}$ to nearly vertical. If the models for cone sheet formation developed by Anderson and
Koide and Bhattacharji are correct, then cone fractures may extend downward from the surface expression of calderas and concentric fissures to a magma body that is considerably narrower than the caldera.

The remarkable similarity and contemporaneity of the eruption at Little Glass Mountain and Glass Mountain, located $15 \mathrm{~km}$ apart, suggest that they were erupted from the same body of magma, possibly along cone fractures. Eruptions at the two vents have the following in common: (1) the same eruption sequence, consisting of 7-8\% tephra and 92-93\% flow; (2) identical major-element compositions for the tephra; (3) nearly identical tephra characteristics, as outlined earlier; (4) similar ages; (5) the lavas have identical trace element compositions (Condie and Hayslip, 1975). The uniqueness of trace element data for individual magma bodies has led to the use of these data to 'fingerprint' tephra deposits for the purpose of correlation (e.g., Borchardt et al., 1971, Howorth and Rankin, 1975).

The total volume of Holocene silicic tephra and lavas is about $1.2 \mathrm{~km}^{3}$. On the basis of the small volume of eruptive rocks, it is possible to make the inference, albeit weak, that the magma body is small. The caldera has a volume of about $8 \mathrm{~km}^{3}$ (Anderson, 1941). If the caldera volume is a reflection of the approximate size of the magma chamber, this is still a relatively small chamber. Also, the caldera volume may reflect the earlier phase of andesitic volcanism and not that of the Holocene silicic eruptions.

The ratio of $1: 9$ for tephra to flows, observed at Glass Mountain and Little Glass Mountain also fits general model for small silicic magma chambers developed by Smith (1976). Interpretation of the structural setting and the petrology of the silicic tephra and lavas erupted in the Medicine Lake Highland during Holocene time supports the hypothesis that there is a small silicic magma body below the highland. Concentric cone fractures may have developed over the apex of a body located at a depth of $4-8 \mathrm{~km}$; this depth is consistent with the model presented by Loide and Bhattacharji (1976) and with observed intrusive-volcanic complexes and elsewhere in the Cascade Range (e.g. Erikson, 1969) and Peru (Cobbing and Pitcher, 1972). If it is true that only 
a small cooling body of magma is present below the highland shield, a reassessment of the area as a potential geothermal area may be necessary. This hypothesis should be kept in mind during the development of the highland which has been classified as 'known geothermal resource area' (Godwin et al., 1971).

The tephra blankets fit a general description of deposits having been formed during Plinian or sub-Plinian eruptions. A Plinian eruption is exceptionally violent and ejects copious pumice (Escher, 1933; Walker and Croasdale, 1970). Tephra were deposited as air fall with no evidence for deposition as pyroclastic flows. An eruption of this kind fits the model outlined above of vesiculated rhyolite magma erupted from the volatile-rich upper portion of a small magma chamber.

Deposition of tephra in beds may be due to individual eruptions related to time of refilling of a fissure, vent blockage, or variation in wind intensity over the volcano. In several tephra units from Glass Mountain and in all units from Little Glass Mountain, concentrations of lithic fragments at the base of each bed indicates clearing of vents or erosion of vent walls during explosive activity.

After the volatile-rich top of the magma chamber was erupted as tephra, the bulk of the lavas with low $(\langle 20-0 \%)$ vesicularities were erupted.

\section{CONCLUSIONS}

(1) Holocene activity in the Medicine Lake Highland consisted of basaltic eruptions on the flanks and eruptions of silicic tephra and lavas near the summit. The rhyolitic eruptions at Class Mountain and Little Glass Mountain occurred during the last. 1100 years.

(2) Air-fall tephra consists of very poorly sorted lapilli that are mostly pumice pyroclasts. The tephra falls formed elongate ovals, extending northeast of Glass Mountain and southwest of Little Glass Mountain. The tephra deposits are similar to those deposited during Plinian eruptions.

(3) Pumice pyroclasts are remarkably homogeneous and consist of blocky, angular forms. Most have elongate simple and compound vesicles and vesicularities of $45-60 \%$. All of the pyroclasts consist of homogeneous rhyolite glass.

(4) The Medicine Lake Highland is located at the intersection of several normal faults; a 'weak spot' that allowed pooling of basaltic magmas needed for crustal melting or a 'conduit' for the rise of diapirs of silicic magma.

(5) The contemporaneity and physical and chemical similarity of tephra and lavas erupted at Glass Mountain and Little Glass Mountain, located $15 \mathrm{~km}$ apart, suggest that they were erupted from the same magma body. They may have erupted along cone fractures developed above the magma chamber. The relatively small volume of Holocene silicic eruptions, small caldera volume, and a ratio of $1: 9$ for tephra and flows suggest that the magma body had an approximate volume of between 2 and $8 \mathrm{~km}^{3}$. If this hypothesis is correct, the highland might have less potential as a geothermal resource than was previously believed.

(6) The blocky, angular pumice pyroclasts may have developed by: (a) vesiculation and elongation of vesicles by flow within $1-2 \mathrm{~km}$ of the surface vent; (b) comminution and disruption of the brittle, vesiculated magma by an expansion, or 'relief' wave passing down into the vent from the magma-atmosphere interface.

\section{ACKNOWLEDGMENTS}

Samuel Gallegos, Jr. was an able field and laboratory assistant throughout the summer of 1976. I wish to thank D. Mann and T. Gregory for their help as well. I benefited from discussions of the Medicine Lake tephra with J. Eichelberger, B. Crowe, and C. D. Miller. Howel Williams and an anonymous reviewer provided useful reviews of the manuscript. This research was supported by the Department of Energy, Division of Basic Energy Sciences under contract W-7405-ENG-36.

\section{REF ERENCES}

Anderson, E. M., 1937. Cone-sheets and ring-dykes: The dynamical explanation. Bull. Volcanol., 1: $35-40$.

Borchardt, G. A., Harward, M. E. and Schmitt, R. A., 1971. Correlation of volcanic ash deposits by activation analysis of glass separates. Quat. Res., 1: 247-260.

Chesterman, C. W., 1955. Age of an obsidian flow at Glass Mountain, Siskiyou County, California. Am. J. Sci., 253: 418-424.

Cobbing, E. J. and Pitcher, W. S., 1972. The Coastal Batholith of central Peru. J. Geol. Soc. London, 128: $421-460$.

Condie, K. C. and Hayslip, D. L., 1975. Young bimodal volcanism at Medicine Lake volcanic center, northern California. Geochim. Cosmochim. Acta, 39: $1165-1178$.

Erikson, E. H. Jr., 1969. Petrology of the composite Snoqualmie batholith, central Cascade Mountains, Washington. Geol. Soc. Am. Bul1., 80: 2213-2239.

Friedman, L., 1968. Hydration rind dates rhyolite flows. Science, 159: 878-880.

Godwin, L. H., Haigler, L. B., Rioux, R. L., White, D. E., Muffler, L. J. P. and Wayland, R. G., 1971. Classification of public lands valuable for geothermal steam and associated geothermal resources. U.S. Geol. Surv. Circ., 647.

Howorth, R. and Rankin, P. C., 1975. Multi-element characterization of glass shards from stratigraphically correlated rhyolitic tephra units. Chem. Geol., 15: 239-250.

Koide, H. and Bhattacharji, 1976. Formation of fractures around magmatic intrusions and their role in ore localization. Econ. Geol., 70: 781-799.

Smith, R. L., 1976. Ash-flow magmatism (abstr.). Geol. Soc. Am. Abstr. Progr., 8: 633-634. 
John C. Eichelberger

Geosciences Division, University of California, Los Alamos Scientific Laboratory, Los Alamos, NM 87545

\section{ABSTRACT}

Mixing of basaltic and rhyolitic magmas at GIass woun appears to have been driven by vesiculation of basaltic magma as it intruded a rhyolitic magma Rapid cooling of basaltic magma formed a mafic foam which floated and became concentrated at the roof of the chamber. Foam-rich lava emerged first during the eruption, and became the hybrid dacite of the distal end of the flow. The chamber is probably a relatively large volume, long-lived feature, lying within $10 \mathrm{~km}$ of the surface beneath the caldera. Eruption of similar lava at Crater Lake shortly before caldera collapse supports this interpretation.

This mechanism of mixing between silicic magma stored in a crustal chamber and basaltic magma feeding the chamber is controlled by initial water content of basaltic magma, and implies that dry basaltic magma would remain at the base of the chamber. The eastward change from andesitic to bimodal volcanism in this portion of the Cascade Range may be due to an eastward decrease in water content of parental basaltic magmas.

\section{INTRODUCTION}

The largest and most imposing product of Holocene activity at the Medicine Lake Highland Volcano is the Glass Mountain lava flow (Figure 1). The most perplexing feature of this flow is its lithologic variety. The $1 \mathrm{~km} s$ of lava which comprises the flow ranges from dull, stony, porphyritic dacite charged with fine-grained mafic xenoliths to shiny, black, phenocryst-free and xenolith-free obsidian. The range in silica content is from 66 wt.\% to 73 wt.\%.

Anderson (1933) described the geologic setting and general petrologic features of the Glass Mountain

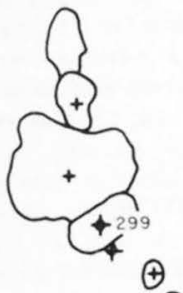

Glass Mountain Flow and Domes

$\oplus$

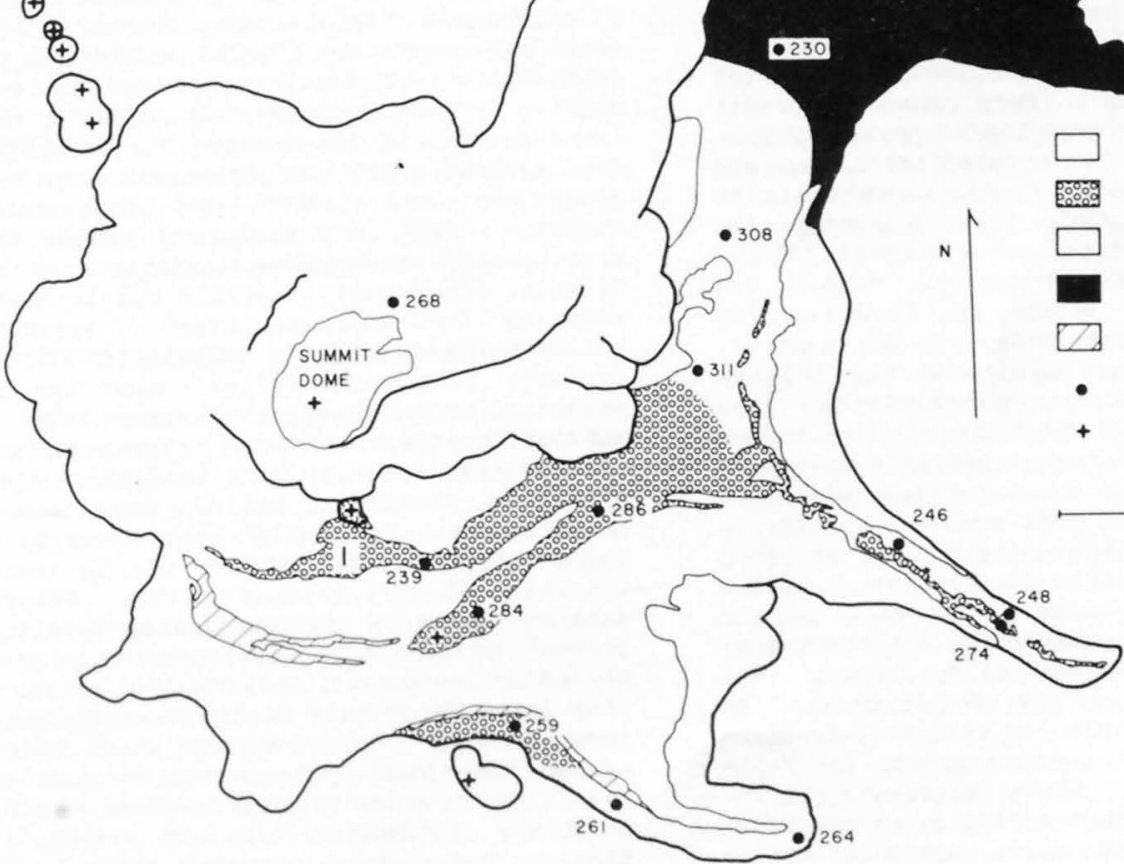

RHYOLITE

RHYOLITE WITH INCLUSIONS BANDED LAVA (RHYODACITE)

DACITE

BRECCIA ZONE

sample location

VENT

KILOMETER

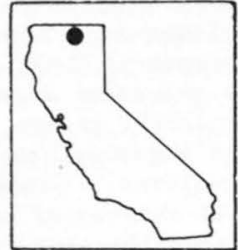

Figure 1. Map of Glass Mountain sample locations and lithologic units. Three digit numbers refer to samples discussed by Eichelberger (1975). Single digit numbers designate sample sites for density measurements discussed in this paper. Modified from Eichelberger (1975). 


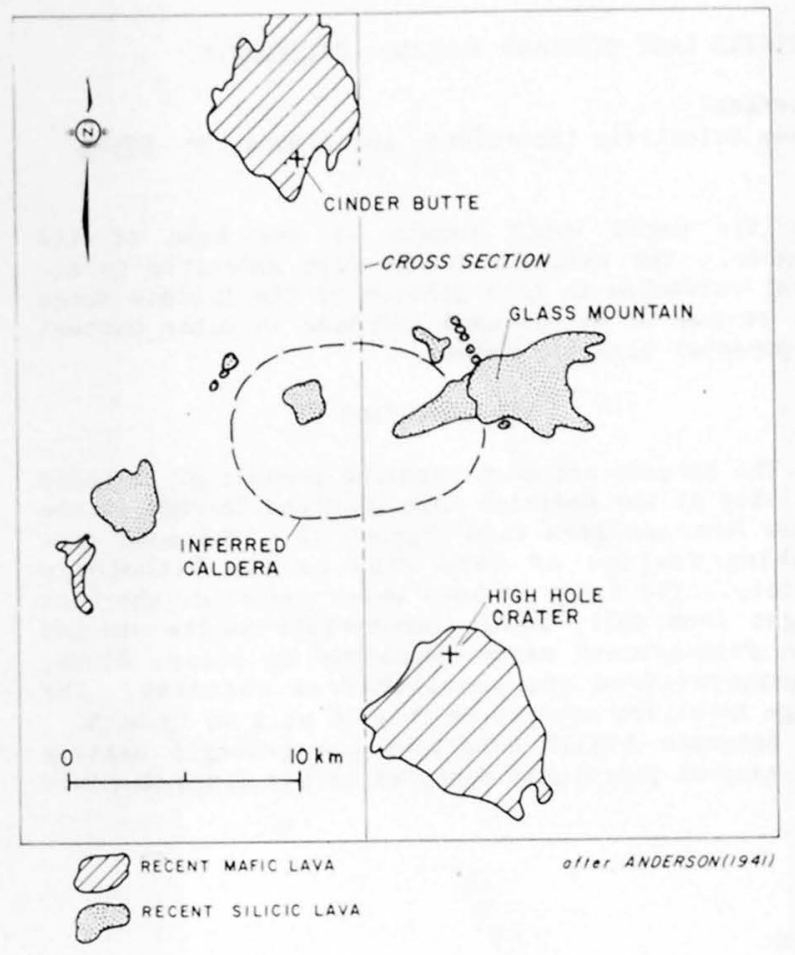

Figure 2. Map showing distribution of Holocene lavas of the Medicine Lake Highland.

flow. Additional data on its age and history were provided by Finch (1928), Anderson (1941), Chesterman (1955), and Friedman (1968). More recently, Condie and Hayslip (1974) and Mertzman (1977) presented geochemical and petrologic data for Highland lavas, and I (Eichelberger, 1975) studied the compositional zonation of the Glass Mountain flow as a means for understanding relationships among magmas of the basalt-andesite-dacite-rhyolite family: Mapping and sampling of lava streams within the flow revealed that the eruption was continuous and, in general, proceeded from homogeneous dacite through highly heterogeneous banded rhyodacite to rhyolite. This suggested a compositional zonation of the parent magma body in which dacitic magma graded downward to rhyolitic magma. Electron microanalysis of phases within the dacite indicated that most of the phenocrysts, An 75 plagioclase, Fo 800 olivine, and $W_{4_{4}} \mathrm{En}_{43}$ $\mathrm{FS}_{16}$ augite, were derived from disaggregation of the crystal-rich basaltic xenoliths. The dark dacitic bands of the heterogeneous rhyodacite are streams of basaltic debris from disintegrating xenoliths. This process was more advanced in the dacite into which the rhyodacite grades, yielding an intermediate magma that was megascopically homogeneous except for residual xenoliths. Since this hybrid magna was concentrated at the top of the chamber, and since the Highland shield through which the magma passed contains a high proportion of mafic lava flows and cinder cones, it was concluded that mafic material had sloughed of $f$ the roof of the magma chamber and contaminated the top of the magma body. However, in subsequent studies of lavas of similar composition from other Cascade volcanoes, I found similar xenoliths and recognized evidence that the xenoliths were liquid when they came in contact with silicic magma (Eichelberger, 1978). This evidence includes:
1. Rounded shape of xenoliths.

2. Texture indicating rapid crystallization to just above solidus.

3. Incorporation of phenocrysts from the host silicic magma in rinds on the outer portions of some large xenoliths.

4. Outward decrease in grain size in some large xenoliths.

5. Reaction or resorption of phenocrysts in the host lava indicating heating of the silicio magma during mixing.

Although the parental rhyolitic magma of Glass Mountain lacked any phenocrysts to record a thermal event associated with mixing, significant orystallization should have occurred if cool rock had been stirred into the chamber. Lack of such crystallization suggested that mixing at Glass Mountain might have in volved two magmas rather than magma and rock, and that a reevaluation of the data was in order.

The arrangement of vents on the Highland, silicic vents associated with a caldera structure and flanked by numerous mafic vents (Figure 2), raises the possibility that mafic magma is supplying a shallow silicic chamber (Figure 3 ). However, such a mechanism would introduce mafic magma to the base of the chamber and would seem to produce a compositional zonation opposite to that observed in the Glass Mountain flow. Evidence that mixing occurs by floatation of basaltic foam in silicic chambers (Eichelberger, 1979) affords a solution to this problem and provides a basis for understanding the evolution of the Medicine Lake magma chamber.

\section{VAPOR EXSOLUTION DURING MIXING}

Mixing of large batches of magma requires flow on a large scale within a magma chamber. A likely mechanism of large scale flow and stirring is convection. Introduction of mafic magma into the base of a chamber would strongly heat silicic magma in the lower portion of the chamber and should induce relatively rapid convection (Rice and Eichelberger, 1976; Sparks and others, 1977). But because the density of basalt is high, any mixing of heated silicic magma with basaltic material would inhibit convection. For example, the density decrease due to heating silicic magma by $100^{\circ} \mathrm{C}$ could be offset by addition of only 2 volume percent basaltic material. The system would probably remain stratified, with the silicic and basaltic layers convecting separately, and mixing limited to diffusion at the interface. Of course, if the basaltic material were less dense than the silicic magma, heating of silicic magma and mixing with basaltic material would both decrease density of magma in the lower portion of the silicic layer, resulting in strong upward flow. Despite the high density of phases crystallized by basaltic magma and present in abundance in the basaltic xenoliths contained in andesitic and dacitic lavas, it appears that the bulk density of these xenoliths is actually less than that of the lavas in which they occur. The reason for this apparent contradiction is that the xenoliths invariably contain abundant, fine, round, uniformly distributed vesicles. Although vesiculation can occur at very shallow depth during eruption, these vesicles may be of deep, primary origin. As stated before, the texture of the xenoliths suggests rapid crystallization of basaltic melt in contact with cooler silicic magma. During the six hours required for a chill wave to propagate $10 \mathrm{~cm}$ into basaltic magma, corresponding to roughly the largest common diameter of the xenoliths, a hydration front could advance only $10^{-2} \mathrm{~cm}$ into the silicic magma, based on data of Shaw (1974). Thus, heat is 


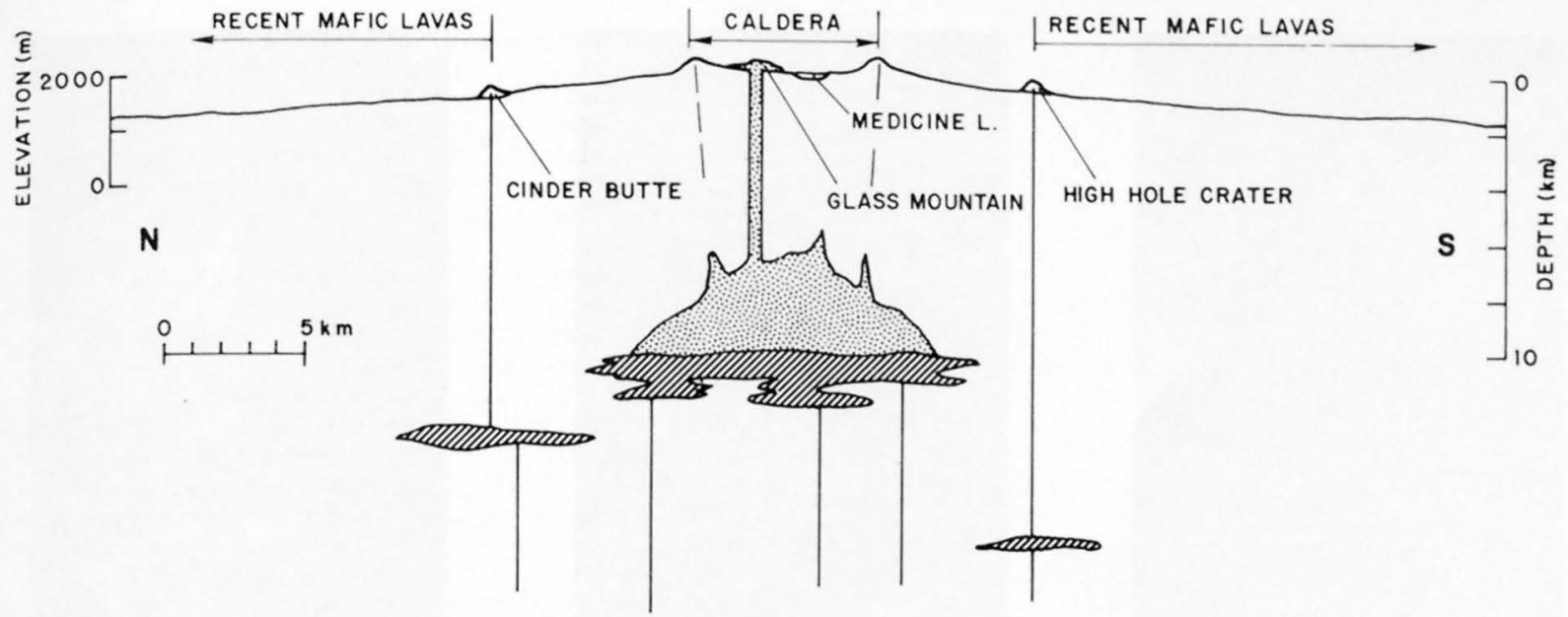

Figure 3. A north-south cross section through the center of the Medicine Lake Highland volcano (line of cross section shown in Figure 2), with major features projected on to the profile. Vertical exaggeration of surface topography is $2 \mathrm{X}$. Silicic magma chamber is shown at depth discussed in text and intermediate in size between the minimum case, a small body at intersection of cone sheet caldera fractures (Heiken, 1978) and the maximum possible extent marked by position of flanking mafic vents.

extracted from the basalt orders of magnitude faster than water, so that the basalt behaves nearly as a closed system with respect to water. Under low to moderate crustal pressures a vapor phase exsolves because water is contained entirely within the melt phase of the system and the melt fraction decreases with crystallization from almost 1.0 to about 0.1 . The result is a basaltic foam layer at the base of the silicic magma body that can float and mix. Floatation of the foam exposes fresh basaltic magma to cool silicic magma, so that the process of foam formation continues. Dispersal of foam through the silicic magma is due to convective flow, driven both by thermal expansion and the positive $\Delta V$ phase change. Photomicrographs showing the Glass Mountain xenoliths to be a crystal-rich foam are presented in Figure 4 .

\section{DENSITY MEASUREMENTS AT GLASS MOUNTAIN}

To test the hypothesis that mixing is driven by vapor exsolution, samples of Glass Mountain lava and xenoliths were collected for density measurements. Several pairs of lava and xenolith samples were collected from sites (Figure 1) near the vent, middle, and distal end of the longest lava stream, representing "rhyolite with inclusions," dacite near the transition to rhyodacite, and the most mafic dacite lava of the flow, respectively (Eichelberger, 1975). Density was determined by measuring dry and submerged weight of samples which ranged in size from $300 \mathrm{~g}$ to $600 \mathrm{~g}$. Results are given in Table 1. The obsidian near the vent has no porosity and a very narrow range of density (smaller than analytical error), $2.38+$ $0.01 \mathrm{~g} / \mathrm{cm}^{3}$. Dacite from midway down the stream is $2.49 \mathrm{~g} / \mathrm{cm}^{3}$. Dacite from the distal end is 2.55 $\mathrm{g} / \mathrm{cm}^{3}$, reflecting its more mafic and crystal-rich character. Bulk density of the xenoliths fall in a surprisingly narrow range, $2.15+0.04 \mathrm{~g} / \mathrm{cm}^{3}$. This density appears little affected by the vesicularity of the host lava, since a xenolith in a pumiceous $\left(1.49 \mathrm{~g} / \mathrm{cm}^{3}\right)$ sample has a density of $2.10 \mathrm{~g} / \mathrm{cm}^{3}$. In order to determine the mass density of xenolith material, xenolith samples were ground to a fine sand to destroy the vesicles. Grain size of the sand averaged $100 \mu \mathrm{m}$ and ranged from $1 \mu \mathrm{m}$ to $400 \mu \mathrm{m}$. Examination of polished grain mounts revealed that grinding opened at least $99 \%$ of the pores. The sand was then weighed dry and submerged. The submerged measurement was made after the sample was subjected to a vacuum for 20 minutes, and water added under vacuum. The resulting density of $2.79+0.01 \mathrm{~g} / \mathrm{cm}^{3}$ was expected for this predominantly plagioclase and pyroxene material. Using the average values for bulk and mass density gives a porosity of $23 \%$. Thus the xenolithic material is much denser than the lava, but because of high porosity, the xenoliths would have floated in the magma chamber. This explains why the most xenolith-rich lava emerged first.

\section{CONDITIONS OF MIXING}

In view of the evidence that the xenoliths floated, and because densities as a function of pressure and temperature of the materials involved are known or approximately known, constraints can be placed on the depth of the magma chamber (Figure 5). Following previous definitions (Eichelberger, 1979). $\rho_{B}$ and $\rho_{X}$ are the mass and bulk densities of the basaltic Xenoliths, so that $\rho_{Y}=\rho_{B}\left(1-X_{Y}\right)+\rho_{Y} X_{Y}$, where $\rho_{V}$ and $X_{Y}$ are the density and volume fraction of the vapor phase, respectively. Bulk density of the foam $\left(\rho_{X}\right)$ versus pressure was calculated at $\mathrm{T}=$ $900^{\circ} \mathrm{C}$ for bulk water content in basaltic magma of $1 \%$, $3 \%$, and $5 \%$, by weight, using the following assumptions:

1. The vapor phase is water.

2. The xenolithic material (exclusive of vapor) is $10 \%$ melt and $90 \%$ crystals. This estimate is based on inspection of thin sections of xenoliths (grain size is too small for accurate modal analysis) and is consistent with the observed mass density. In the general case, degree of crystallization is dependent largely on temperature contrast between the basaltic and silicic magmas. 

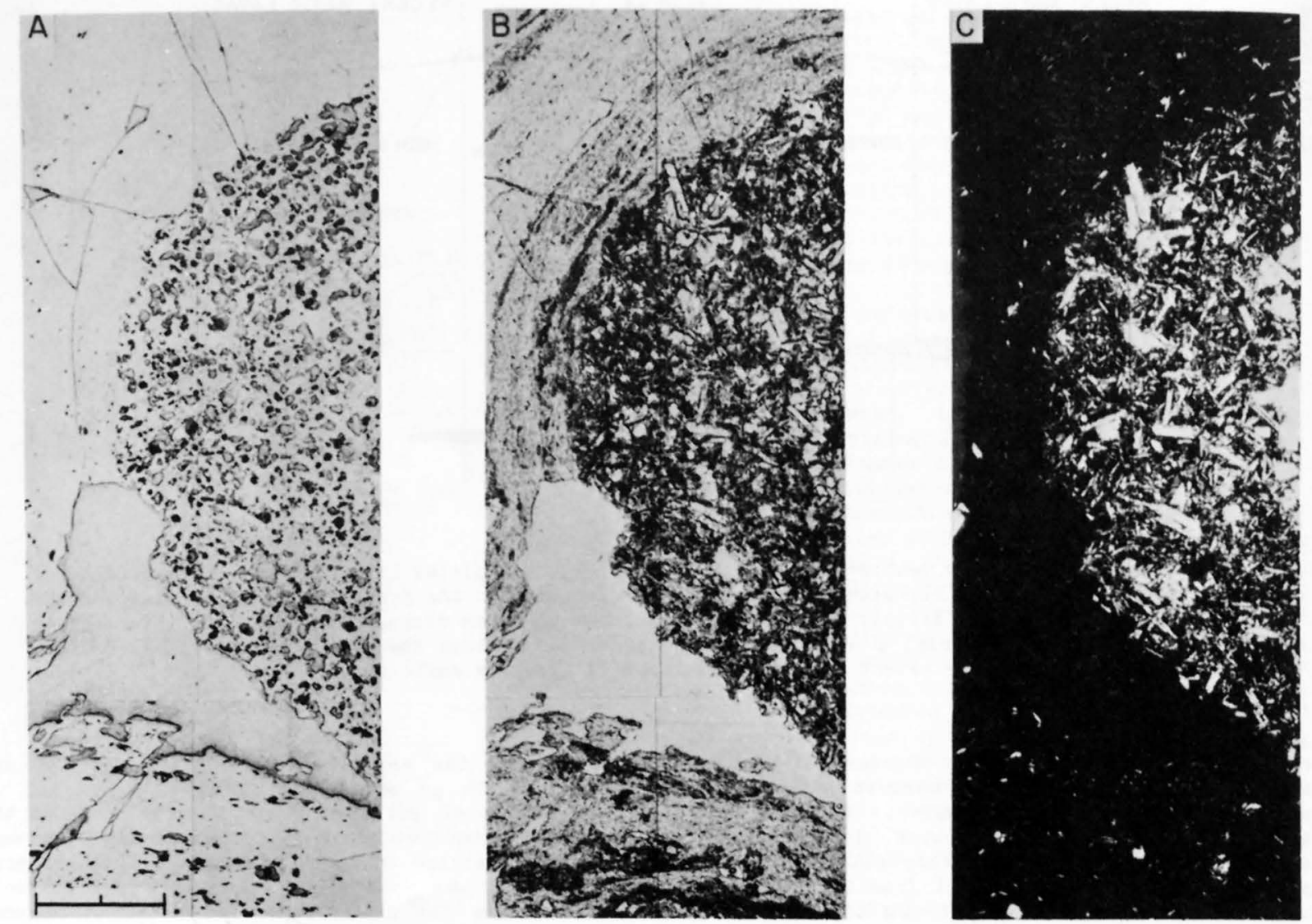

Figure 4. Photomosaics of basaltic xenolith in banded rhyodacite lava from Glass Mountain. Views are reflected light (A), transmitted light (B), and transmitted light with crossed polars (C). Bar length is $1.0 \mathrm{~mm}$. Note abundant, $0.1 \mathrm{~mm}-\mathrm{diameter}$ vesicles in xenolith (A) and absence of vesicles in most of the host lava, except for a large vesicle at the lower left edge of the xenolith. Lava at the bottom is contaminated with basaltic material and contains some vesicles. In B, the xenolith is a dark round object with prominent white plagioclase crystals. Pyroxene is also a major phase, with olivine, oxides, and glass present in lesser amounts. The large vesicle associated with the xenolith is an irregular white area. Lava contaminated with basaltic material shows up as dark streaks. In C, the crystal-rich character of the xenolith is apparent. Contaminated lava contains more crystals than uncontaminated lava.

3. The xenolithic material is incompressible. In fact, the melt becomes less dense with increasing pressure because more water is retained and plagioclase and pyroxene compress, but the effects are small, opposite and nearly equal.

The measured value of $\rho_{B}$ was used, correcting for thermal expansion of ${ }_{\mathrm{B}}^{\mathrm{B}}$ agioclase and pyroxene (Skinner, 1966). Data of Burnham and Jahns (1962) were used for solubility of water in melt, and data of Burnham and others (1969) were used for density of the vapor phase $\left(\rho_{y}\right)$. The resulting curves (Figure 5) show the density of the foam formed during mixing at a specified pressure and water content of basaltic magma. Portions of $\rho_{x}$ versus pressure curves for constant porosity of foam are also shown.

Density of magma in the chamber before mixing can be estimated for elevated temperature and pressure by assuming that rhyolitic glass and melt behave in a manner similar to glass and melt in the system albite + water (Burnham and Davis, 1971). The petrologic data indicate that magma in the chamber was entirely rhyolitic melt. Hence the density measurements for rhyolite obsidian were used. Water content strongly affects both thermal expansion and compressibility of rhyolite glass and melt. Available analyses give water contents of Glass Mountain obsidian of a few tenths of a percent (Anderson, 1941). Therefore, $P$ versus pressure at $900^{\circ} \mathrm{C}$ was calculated for $O$ and wt.\% water. Knowledge that the xenoliths floated constrains xenolith density to those portions of the $\rho_{x}$ curves left (lower density) of the dry $p_{p}$ curve. EStimates of water content for high alumina basaltic magma of the type involved in mixing range upward to 5 wt.\% (Anderson, 1974; Rose and others, 1978). This constrains pressure to a region above (lower pressure) the 5 wt.\% water oy curve. Since the xenoliths have most likely experienced continuously decreasing pressure since formation, it is unlikely that they ever possessed higher than their present (surface) porosity $\left(X_{y}\right)$, which constrains xenolith density to the right (higher density) of the $x_{y}=0.23$ curve. 
TABLE 1. Densities of Glass Mountain Samples

Sample

(Fig. 1)

$1 A$
$1 B$
$1 B$
$1 C$
$1 D$
$1 E$
$2 A$
$2 B$
$3 B$
$3 B$
$3 B$

Averages
2.14

2. 13

2. 14

2. 20

2. 18

2. 10

2. 10

2.23

2. 15

2. 13

2. 11

2. $15 \pm 0.04$
Density of host lava $\left(\mathrm{g} / \mathrm{cm}^{3}\right)$

2. 40

2. 37

2. 37

2. 38

2. 39

.1. 49

2.49

2.49

2.25

2. 42

2.55

$2.38+0.01$

2.49

2. 55
Sample

Description

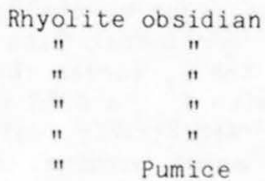

Nonvesicular dacite

Vesicular dacite

Nonvesicular dacite

Rhyolite obsidian

Nonvesicular dacite, site \#2

Nonvesicular dacite, site \#3

Sample Mass Density, Xenolith $\left(\mathrm{g} / \mathrm{cm}^{3}\right)$

$1 \mathrm{~B}$
$1 \mathrm{D}$
$2 \mathrm{~A}$

Aver age
2.79

2.79

2.78

$2.79 \pm 0.01 \quad x_{V}=0.23$

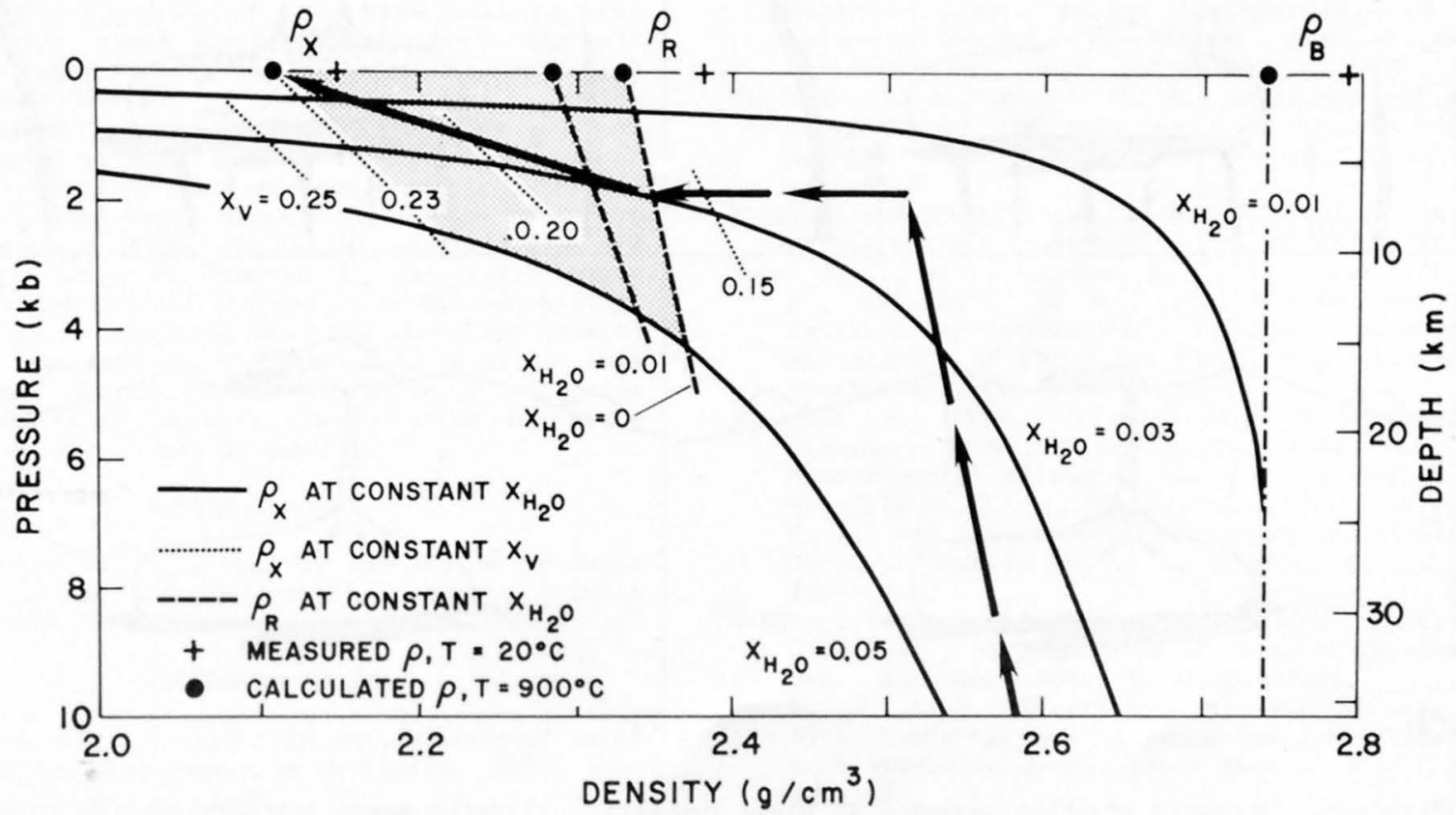

Figure 5. Density versus pressure (depth) for materials from Glass Mountain. py is bulk density of basaltic foam (xenoliths), $\rho_{R}$ is density of the reservoir magma, and $\rho_{B}$ is mass density of xenolithic material. The possible region for the Glass Mountain magma chamber is shaded. Arrows show path for ascending basaltic magma with 3 wt. water. See text for further discussion. 
These constraints bound the shaded region in Figure 5. If we knew that the basalt initially contained 3 wt.\% water, which is probably more reasonable since Medicine Lake basalt eruptions are much less gaseous than the Fuego eruptions for which the 5 wt.\% water estimate was made, then the possible region would be a small triangle bounded below by the $\rho_{x}$ curve for 3 wt. $\% \mathrm{H}_{2} \mathrm{O}$, to the right by the appropriate $\rho_{\mathrm{B}}$ curve, and above by a horizontal line extending from the intersection of the $\rho_{x}$ curves for 3 wt. $\% \mathrm{H}_{2} \mathrm{O}$ and 23\% porosity (foam with $\mathrm{X}_{\mathrm{H}}=0.03$ above this line would have $\left.X_{y}>0.23\right)$. Regrettably, water content of basaltic magma is a major unknown, but it seems likely from these considerations that the Glass Mountain magma chamber lies within $15 \mathrm{~km}$ and probably within $10 \mathrm{~km}$ of the surface.

A possible path of ascending basaltic magma is shown as arrows in Figure 5, assuming $\mathrm{X}_{\mathrm{H}_{2} \mathrm{O}}=0.03$ for basalt and $\mathrm{X}_{\mathrm{H}_{2}}=0$ to 0.01 for rhyolite. The basalt ascends through the crust, slowly becoming less dense as indicated by the steep path from $10 \mathrm{~kb}$ to $2 \mathrm{~kb}$. Densities along this path were calculated using average Medicine Lake basalt (Anderson, 1941) and the model of Bottinga and Weill (1970). Note that at 2 $\mathrm{kb}$ the magma is still vapor undersaturated. However, at this depth it enters the Glass Mountain magma chamber, undergoes rapid crystallization while exsolving a vapor phase, and forms a foam with $2.74 \mathrm{~g} / \mathrm{cm}^{3}, X_{v} \geq 0.17$, and ${ }^{\rho} x \leq 2.34 \mathrm{~g} / \mathrm{cm}^{3}$. If this foam remained rigid but leaked after formation it would follow a constant porosity curve to the surface. If it maintained an equilibrium pore pressure and did not leak, it would follow a constant water curve and blow up during ascent. The path shown is intermediate: some leakage and some expansion to the observed $x_{y}=0.23$. The Glass Mountain xenolith probably did leak, since most xenoliths have a large vesicle at the lava/xenolith interface, as shown in Figure 4. Inflation of the foam does work, energy for which is supplied largely by crystallization. At $2 \mathrm{~kb}$, energy available from crystallization is nearly two orders of magnitude greater than energy required for inflation.

\section{THE GLASS MOUNTAIN ERUPTION}

Important implications of this discussion for Glass Mountain are that water played an important role in magma evolution and that the chamber lies at shallow depth. A probable reconstruction of the eruption sequence is shown in Figure 6. Basaltic magma intruded the chamber and formed a foam which floated and mixed (in a mechanical sense) with magma in the chamber. The subsequent eruption first tapped
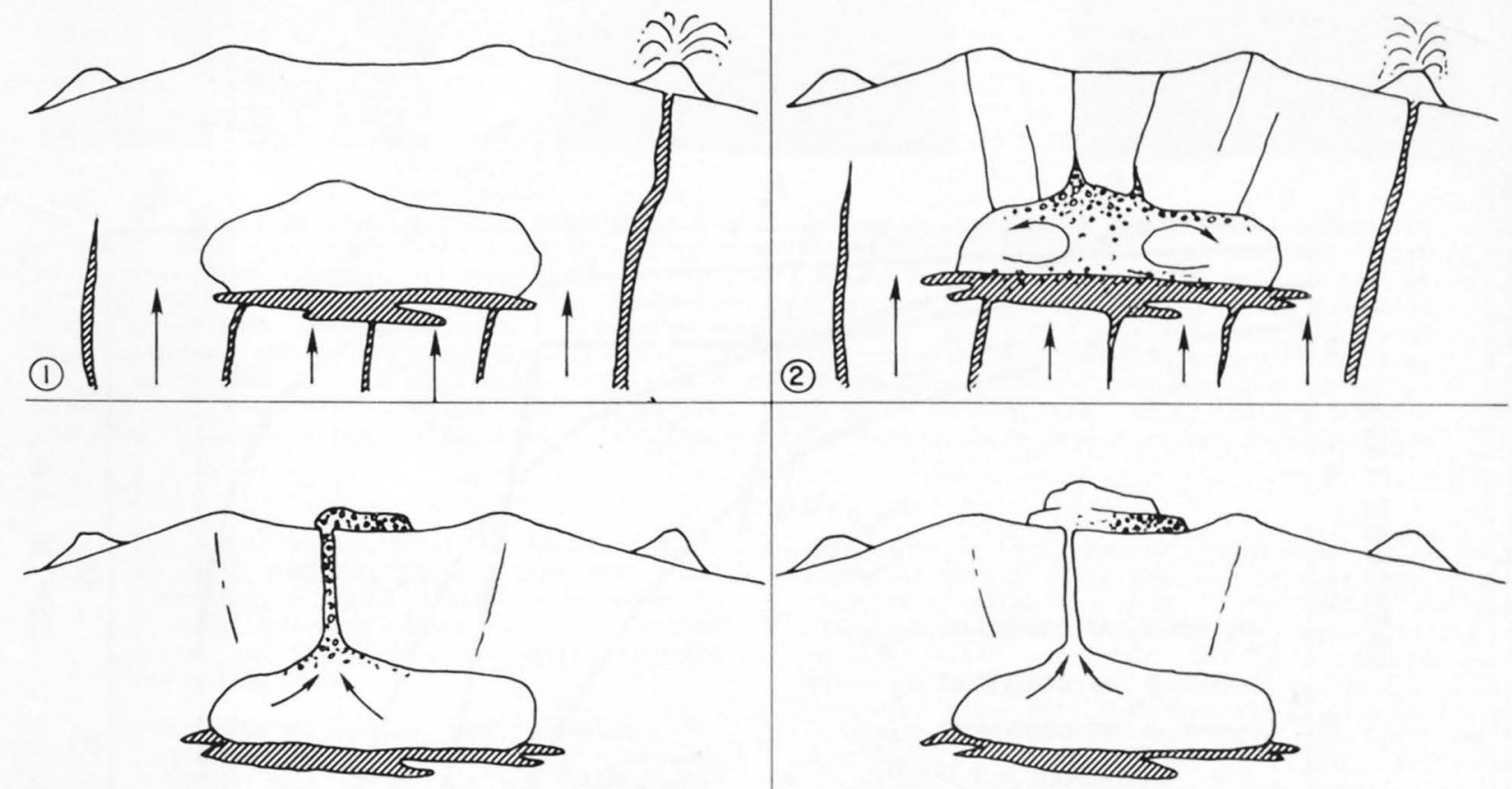

(3)

(4)

Figure 6. Probable eruption sequence at Glass Mountain. (1) Mafic magma intrudes shallow rhyolitic magma chamber and erupts nearby at High Hole Crater. (2) Vesiculation of chilled mafic magma forms foam which floats and mixes in the convecting chamber. (3) Vesiculation in chamber triggers eruption, which first taps hybrid dacite concentrated near roof of chamber. (4) Eruption continues with extrusion of rhyolite magma. Rhyolitic tephra which underlies Glass Mountain may have erupted early in this sequence, as an immediate response to intrusion of mafic magma into the chamber, before mixing was far advanced. Alternatively, low density of water-rich rhyolitic magma at the top of the chamber may have prevented further rise of foam-rich currents, so that a small rhyolitic cap remained near the chamber roof and erupted as tephra just before the hybrid dacite. 
the hybrid which was concentrated at the top of the chamber. Evidence that vapor exsolution occurred within the chamber suggests that mixing triggered the eruption. Assuming that $0.2 \mathrm{~km}^{3}$ of the flow is a $1: 3$ mixture of basalt and rhyolite, then the volume of vapor exsolved within the chamber was $0.01 \mathrm{~km}^{3}$. Some of this almost certainly leaked from the foam and dissolved in the strongly water undersaturated rhyolitic melt. Nevertheless, a rapid volume increase within the chamber could most easily be accommodated by extrusion of material from the chamber. Thus, the mixing and eruption events were probably closely spaced in time, and may correlate with the extrusion of mafic magma $10 \mathrm{~km}$ to the south on the flanks of the Highland at High Hole Crater and its associated Burnt Lava Flow. Similar rhyolite and hybrid dacite have erupted before near Glass Mountain and el sewhere near the summit of the Highland. These may be products of repeated intrusion of basaltic magma into a relatively large, shallow, long-lived magma chamber beneath the caldera (Figure 3 ). This would account for the liquidus or superheated condition of some of these lavas, as indicated by their lack of phenocrysts.

Although water content of basaltic magma is a major unknown, the high initial density contrast between basaltic and reservoir magmas (Eichelberger, 1979) constrains the Glass Mountain chamber to shallow depth. Both silicic composition and scarcity of phenocrysts in the reservoir magma contribute to this high density contrast. A remarkably similar high density contrast mixture erupted from Mt. Mazama to form the Llao Rock dacite flow, just prior to the crater Lake event. The subsequent climactic tephra eruption shows that Mt. Mazama overlay a large shallow reservoir containing crystal-poor siicic magma, with mafic magma at the base of the reservoir. The Glass Mountain data suggest that this condition now exists beneath the Medicine Lake Highland.

Another consequence of this hypothesis is that mixing between magma stored in a crustal reservoir and mafic magma feeding the reservoir is controlled by the water content of the mafic magma. Mixing during replenishment of crustal magma reservoirs offsets compositional effects of fractionation or crustal melting, so that eruption products of reservoirs fed by wet mafic magma will tend to be intermediate in composition. Volcanism resulting from dry mafic magma will be bimodal because mafic magma remains at the base of the reservoir without mixing. Anderson (1974) suggested that Medicine Lake basalts are drier than those to the west of Mt. Shasta. This may account for the bimodal character of volcanism east of the High Cascades, farther from the plate boundary and the source of water.

\section{ACKNOWLEDGMENTS}

This work was supported by the office of Basic Energy Sciences, U.S. Department of Energy. David Mann prepared the thin section shown in Figure 4.

\section{REFERENCES CITED}

Anderson, A. T., Jr., 1974, The before-eruption water content of some high-alumina magmas: Bull. Volcanol., V. 37, p. 530-552.

Anderson, C. A., 1933, Volcanic history of Glass Mountain, northern California: Am. Jour. Sci., V. 226, p. $485-506$.
Anderson, C. A., 1941, Volcanoes of the Medicine Lake Highland, California: Univ. California Pubs. Geol. Sci., v. 25, p. 347-422.

Bottinga, Y. and Weill, D. F., 1970, Densities of liquid silicate systems calculated from partial molar volumes of oxide components: Am. Jour. Sci., v. 269, p. 169-182.

Burnham, C. W. and Davis, N. F., 1971, The role of $\mathrm{H}_{2} \mathrm{O}$ in silicate melts: I. $\mathrm{P}-\mathrm{V}-\mathrm{T}$ relations in the system $\mathrm{NaA} 1 \mathrm{Si}_{3} \mathrm{O}_{8}-\mathrm{H}_{2} \mathrm{O}$ to 10 kilobars and $1000^{\circ} \mathrm{C}$ : Am. Jour. Sci., V. 270, p. 54-79.

Burnham, C. W., Holloway, J. R., and Davis, N. F., 1969. Thermodynamic properties of water to $1000^{\circ} \mathrm{C}$ and 10,000 bars: Geol. Soc. Amer. Spec. Paper 132, p. 1-96.

Burnham, C. W. and Jahns, R. H., 1962, A method for determining the solubility of water in silicate melts: Am. Jour. Sci., V. 260, p. 721-745.

Chesterman, C. W., 1955, Age of the obsidian flow at Glass Mountain, Siskiyou County, California: Am. Jour. Sci., V. 253, p. 418-424.

Condie, K. C. and Hayslip, D. L., 1975, Young bimodal volcanism at Medicine Lake volcanic center, northern California: Geochim. Cosmochim. Acta, v. 39, p. 1165-1178.

Eichelberger, J. C., 1975, Origin of andesite and dacite: Evidence of mixing at Glass Mountain in California and at other circum-Pacific volcanoes: Geol. Soc. Amer. Bull., V. 86, p. 1381-1391.

Eichelberger, J. C., 1978, Andesitic volcanism and crustal evolution: Nature, V. 275, p. 21-27.

Eichelberger, J. C., 1979, Vapor exsolution and mixing during replenishment of crustal magma reservoirs: Submitted to Nature.

Finch, R. H., 1928, Lassen report No. 14. Volcano Letter, V. 161, p. 1.

Friedman, I., 1968, Hydration rind dates rhyolite flows: Science, V. 159, p. 878-880.

Heiken, G., 1978, Plinian-type eruptions in the Medicine Lake Highland, California, and the nature of the underlying magma: Jour. Volcanol. Geothermal Res., V. 4, p. 375-402.

Mertzman, S. A., Jr., 1977, The petrology and geochemistry of the Medicine Lake Volcano, California: Contrib. Mineral. Petrol., v. 62, p. $221-247$.

Rice, A. and Eichelberger, J. C., 1976, Convection in rhyolite magma (abstract): EOS, V. 57, p. 1024.

Rose, W. I., Jr., Anderson, A. T., Jr., Woodruff, L. G., and Bonis, S. B., 1978, The October 1974 basaltic tephra from Fuego Volcano: Description and history of the magma body: Jour. Volcanol. Geothermal Res., V. 4, p. 3-54.

Shaw, H. R., 1974, Diffusion of $\mathrm{H}_{2} \mathrm{O}$ in granitic liquids: Part I. Experimental data; Part II. Mass transfer in magma chambers: in Hofman, A. W., Giletti, B. J., Yoder, H. S., Jr., and Yund, R. A., eds., Geochemical transport and kinetics. Carnegie Institution of Washington, v. 634, p. 139-170.

Skinner, B. J., 1966, Thermal expansion: in $\mathrm{Clark}$, S. P., Jr., ed., Handbook of Physical Constants. Geol. Soc. Amer. Mem., v. 97, p. 78-96.

Sparks, R. J. S., Sigurdsson, H., and Wilson, L., 1977. Magma mixing: A mechanism for triggering acid explosive eruptions: Nature, v. 267, p. $315-318$. 